\title{
Survival, predation, and behaviour of the Mahoenui giant wētā (Deinacrida mahoenui: Anostostomatidae: Orthoptera)
}

By

Hannah Joan Stilborn

A thesis submitted to the Victoria University of Wellington in fulfilment of the requirements for the degree of Master of Science in Ecology and Biodiversity

School of Biological Sciences

Victoria University of Wellington

June 2019 


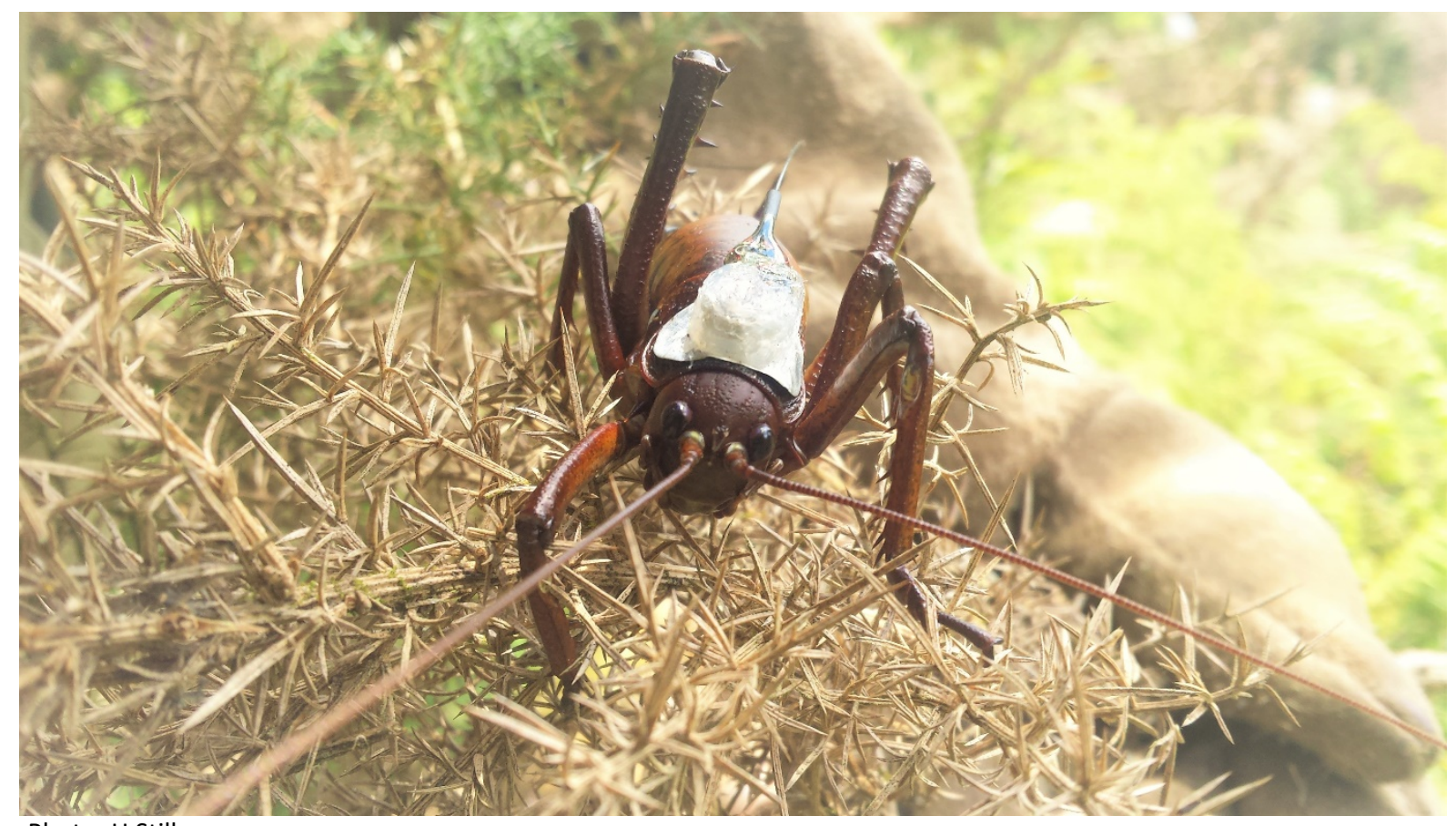

Photo: H Stilborn

This thesis should be cited as follows:

Stilborn, H J. (2019). Survival, predation, and behaviour of the Mahoenui giant wètā (Deinacrida mahoenui: Anostostomatidae: Orthoptera). (Unpublished masters thesis), Victoria University of Wellington, Wellington, New Zealand. 


\section{Abstract}

Introduced mammalian pests, such as rats (Rattus spp.), house mice (Mus musculus), brushtail possums (Trichosurus vulpecula), and European hedgehogs (Erinaceus europaeus), have been implicated in the suppression or extinction of many endemic invertebrate species in New Zealand, including the large-bodied giant wētā (Anostostomatidae: Deinacrida). The Mahoenui giant wētā (MGW; D. mahoenui) is the only lowland giant wētā species still naturally present on the mainland of New Zealand, where the last remaining individuals of the original population are currently restricted to an 187ha mainland reserve (Mahoenui Giant Wētā Scientific Reserve; MGWSR) in Mahoenui, western King Country. Having sought refuge in the introduced woody shrub, gorse (Ulex europaeus), these wētā have survived in the presence of introduced mammalian predators for almost six decades. However, due to natural succession, the reserve is gradually reverting to native bush and wētā monitoring data shows potential signs of population decline. Concerns for the species survival have been raised as it is unknown how wētā will cope in an altered habitat alongside mammalian predators.

In chapter 2, we used 14-years' of site-occupancy monitoring data to explore changes to the reserves' gorse mosaic and MGW population. We additionally assessed the effect of abiotic covariates on MGW occupancy and detection probabilities in 2005 and 2018. Furthermore, we assessed mammalian pest population dynamics within the reserve over the past seven years. Significant changes to the reserve's gorse mosaic were identified, whereby unbrowsed, tall bushes, which may provide less protection to wētā, are now dominant in 2018. Population trajectory analysis revealed the MGW population has decline since 2012. This result was consistent with naïve occupancy estimates and the increase in search time (0.3hrs/year) required to find wētā, suggesting the population is in a state of decline. Plot location was identified as an important covariate for predicting MGW occupancy in 2018, whereby plots in edge habitat, potentially being preferred or safer, had a higher occupancy probability. Mammalian pests (rats, house mice, brushtail possums, and European hedgehogs) appear to be present within the reserve year-round, populations peaking in summer and autumn. 
In chapter 3 , we used radiotelemetry to explore MGW survival rates, movement patterns, and diurnal refuge use in gorse and native vegetation during summer $(n=14)$, autumn $(n=31)$, and spring $(n=10)$. Survival rates, in relation to predation, revealed MGW inhabiting native vegetation were nine times more likely to be predated than those inhabiting gorse. This result suggests native species such as mahoe (Melicytus ramiflorus), and tree ferns (Dicksonia fibrosa and Cyathea spp.) do not provide good protection to MGW from mammalian predators. Assessment of movement behaviour revealed MGW move less in autumn ( $3 \mathrm{~m} / 48 \mathrm{hrs})$ compared to summer ( $10 \mathrm{~m} / 48 \mathrm{hrs})$ and spring $(\sim 8 \mathrm{~m} / 48 \mathrm{hrs})$, and most commonly follow a movement pattern consistent with random-walk. Movement behaviour was also found to be temperature dependant, with both male and female MGW moving significantly further in warmer weather $\left(>13.5^{\circ} \mathrm{C}\right)$. Radiotracked MGW were found to take refuge above $2.5 \mathrm{~m}$ in the canopy of native vegetation, whereas in gorse habitat, wētā were most commonly found taking refuge between $0.62-2.38 \mathrm{~m}$ in the denser foliage of unbrowsed gorse bushes. Furthermore, no radiotracked wētā were observed with another individual in autumn, compared to eight and 26 observations in summer and spring.

In chapter 4 , we attempted to identify potential mammalian predators of the MGW by analysing the stomach contents of ship rats ( $R$. rattus; $n=10)$, house mice $(n=10)$, brushtail possums ( $n=5)$, and feral cats (Felis catus; $n=2$ ). Ship rats were identified as likely predators of MGW within the MGWSR. However, due to the limited number of stomachs and species analysed, further analysis is recommended. Collectively, these results provide an overview of the MGW reserve and population status, in addition to important ecological information that can be used to inform future management, monitoring, and translocation. 


\section{Acknowledgements}

I would like to express my appreciation to the following people or organisations that assisted with or contributed towards this project

Firstly, I would like to acknowledge my supervisors, Dr Stephen Hartley and Dr Corinne Watts for your expertise, support, and guidance throughout this project. I could not have asked for better mentors and really appreciate all the time and effort you gave to project and myself. I have learnt so much over the past two years and am forever grateful to you both.

I gratefully acknowledge the support given by Amanda Haigh, Abi Quinnell, Lucy Bridgman, Jessica Scrimgeour, Tertia Thurley, Thomas Emmitt, Peter Bird, and Erana Stevens (all DOC) with logistics and field gear.

I would like to thank the MGW search teams, including Corinne Watts, Danny Thornburrow, DOC Maniapoto staff (Thomas Emmit, Tom Quinnell, Abi Quinnell, Antoinette Wilson, Athena Irvine, Sarah Tunnicliffe), DOC Pureora staff (Liesl Van Wyk, Leigh Roderick, Logan Moore, Eliska Blattner-De Vries, Harriet Kemp, Bernie Buhler), DOC Taupo staff (Amanda Haigh), DOC Turangi staff (Jessica Scrimgeour), Otorohanga Kiwi House staff (Greta Horne, John Malan, Danielle Hawkins), Garry Coles, Ngatai and Hemi Rauputu, William Wetere, Bryce, Rachel and Ben Stilborn, and University of Waikato summer scholars Karina Radley and Callum Parker. I would also like to thank Bernie Buhler for running the trapping of possums and cats.

I appreciate the generosity of Manaaki Whenua - Landcare Research, Hamilton, specifically Corinne Watts and Gary Harrison, for allowing me to use laboratory facilities and an e-bike while conducting field work. I also greatly appreciate the assistance provided by Corinne Watts, Scott Bartlam, and Stephen Thorpe (Independent researcher, Auckland) with invertebrate identification.

I would like to thank Darryl MacKenzie (Proteus wildlife research consultants) for providing support with occupancy modelling and members of the 'Bug Club' for their feedback on presentations and chapters. 
I greatly appreciate the support of the Mokau Ki Runga Regional Management Committee and surrounding landowners Jo and Andrew Gaston, and Ngatai and Marina Rauputu. I also thank Lynette and Dion Adams for providing accommodation for the duration of my field work. I really appreciate your hospitality and willingness to lend a hand.

To my family, particularly my parents Bryce and Pam Stilborn. I couldn't have done this without your never-ending belief and support throughout these 5 long years. If I ever needed help you were just a phone call away. There were a few times during this project where I was struggling, but you encouraged me to keep going and I owe the completion of this thesis to you. To my second family in Wellington, May, Pierre, Maya, Marie-belle, and Leo. Thank you for your support throughout my masters and I am forever grateful for the many home cooked meals.

Finally, I would like to thank Joe Marcha for his enthusiasm in my work, sticking it out through the long months apart, and motivating me to keep going.

This project would not have been possible without the funding provided by the Department of Conservation and Victoria University of Wellington. Funding was also provided by the Centre for Biodiscovery and Restoration Ecology and the Mahoenui Stock Scheme. 


\section{Table of Contents}

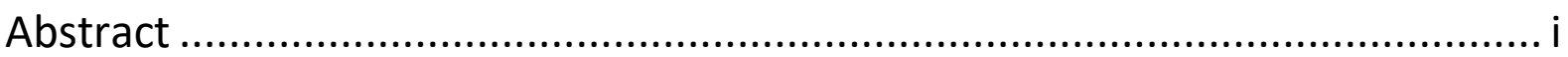

Acknowledgements .............................................................................. ii

List of Figures........................................................................................ vii

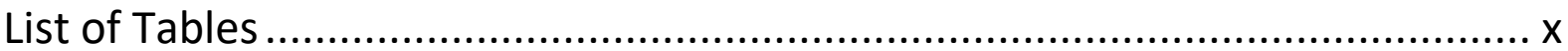

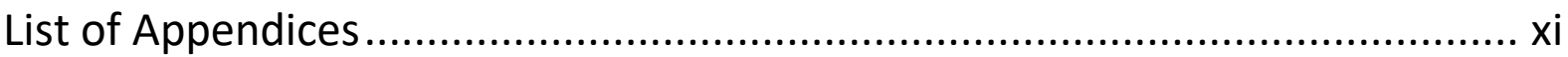

Chapter 1. General introduction ......................................................... 1

1.1 The impact of introduced mammalian predators on New Zealand invertebrates........1

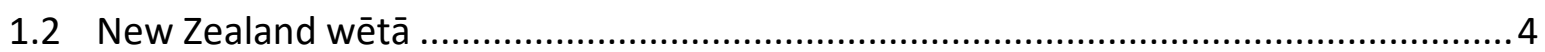

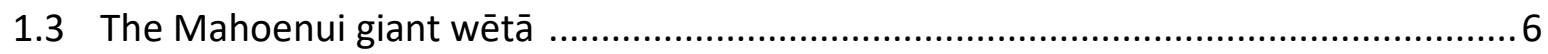

1.3.1 MGW management and research to date ................................................... 7

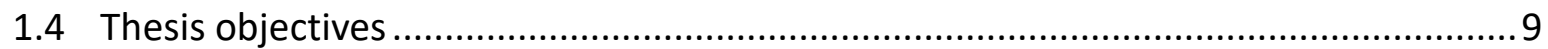

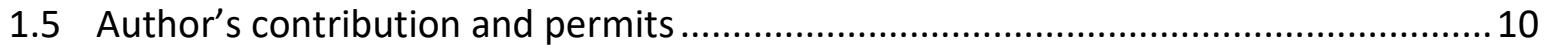

Chapter 2. The status of a giant wētā population (Deinacrida mahoenui) in a gorse dominated reserve ........................................................................ 13

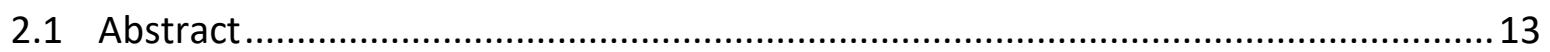

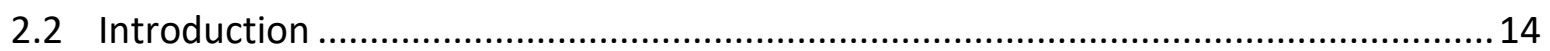

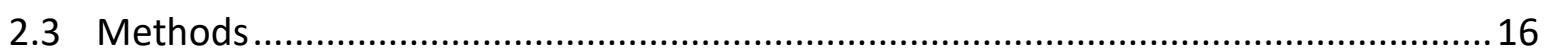

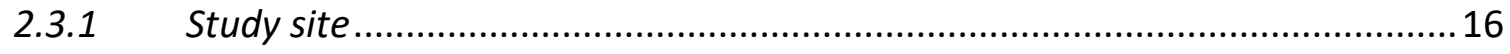

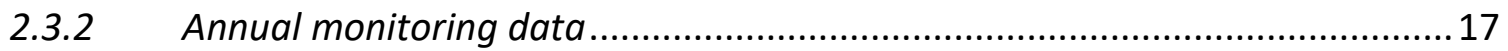

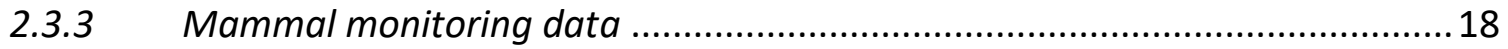

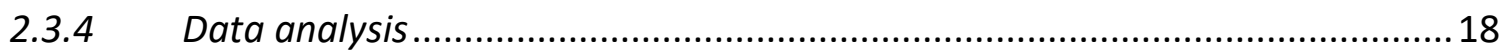

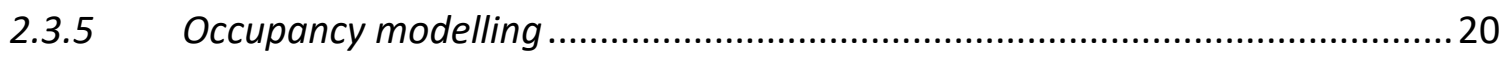

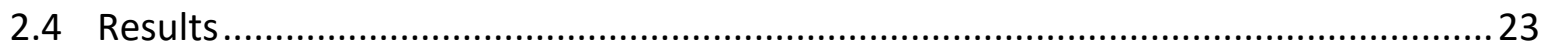

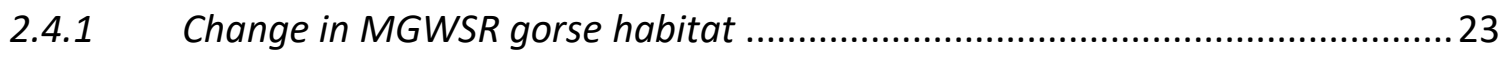

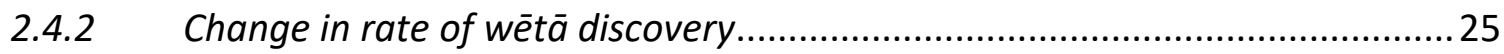

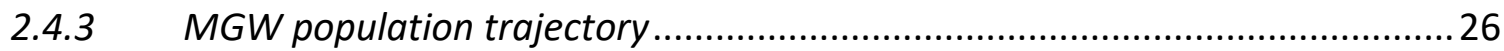

2.4.4 Abiotic effects on MGW occupancy and detection .........................................29 


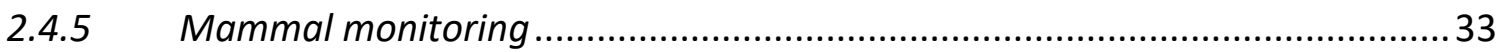

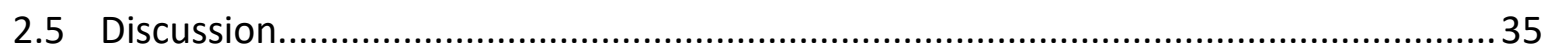

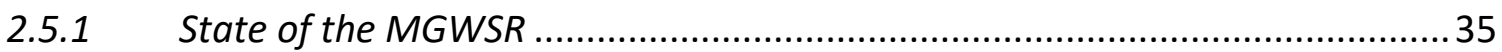

2.5.2 Status of the giant wētā population at Mahoenui ............................................35

2.5.3 Abiotic effects on MGW occupancy and detection ........................................ 37

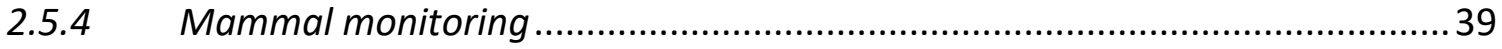

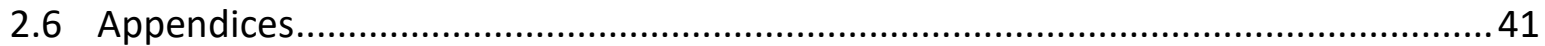

\section{Chapter 3. Survival and behaviour of Mahoenui giant wētā (Deinacrida} mahoenui) in gorse and native vegetation habitats ................................ 52

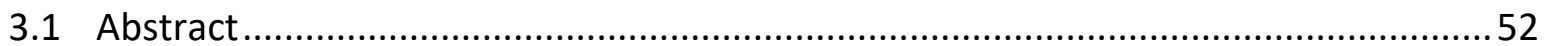

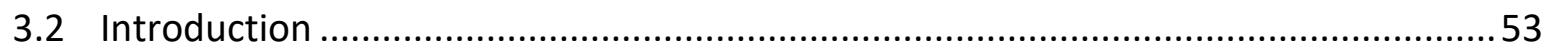

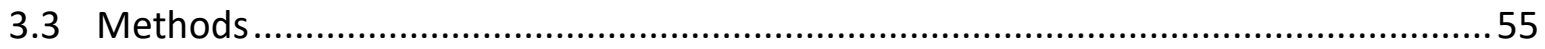

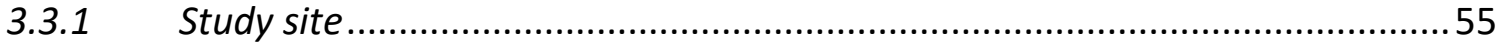

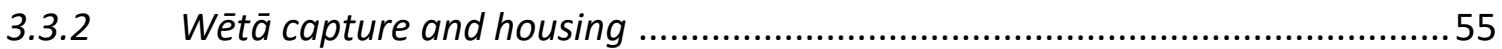

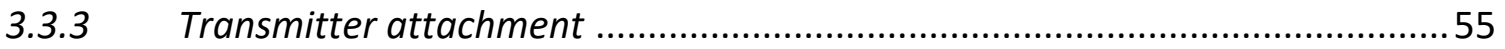

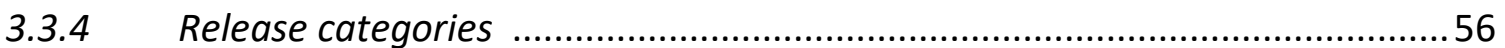

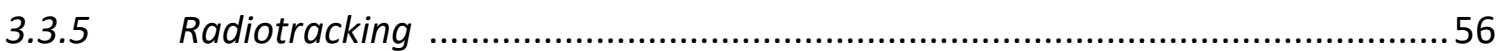

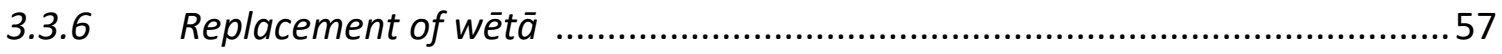

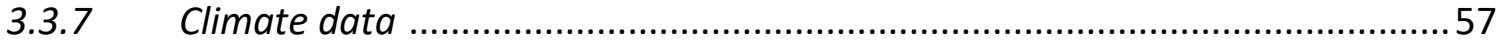

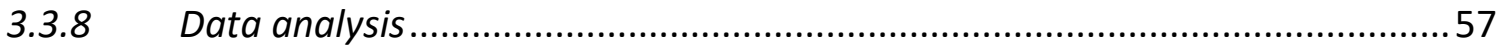

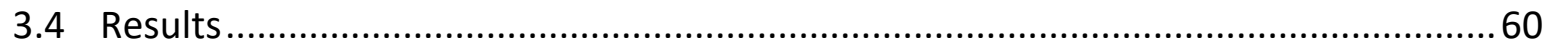

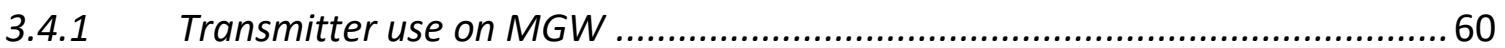

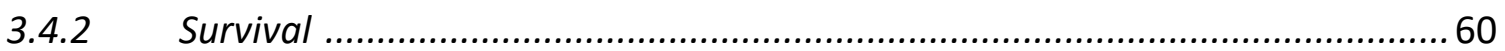

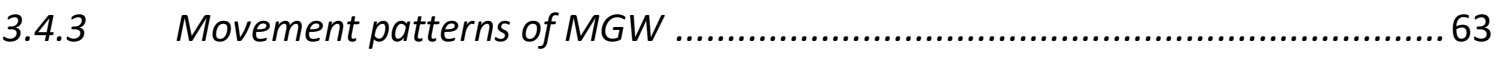

3.4.4 Wētā observations during radiotracking ..................................................... 71

3.4.5 Diurnal refuge use in gorse and native vegetation ..................................... 72

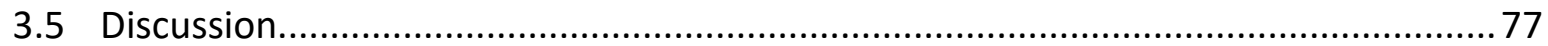

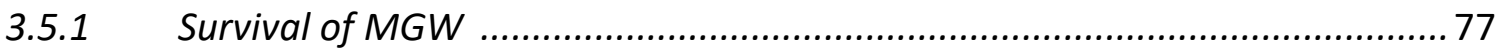

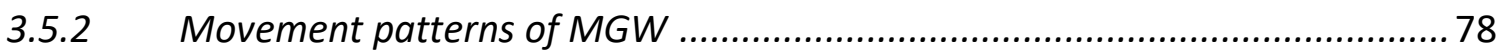

3.5.3 Diurnal refuge use in gorse and native vegetation ...................................... 81

3.5.4 Radio-transmitters as a monitoring tool for MGW ....................................... 82

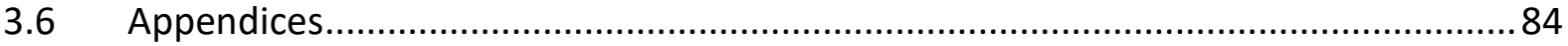




\section{Chapter 4. Stomach contents of potential mammalian predators of}

Mahoenui giant wētā (Deinacrida mahoenui) ......................................... 102

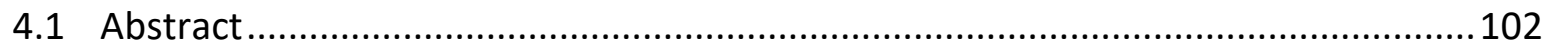

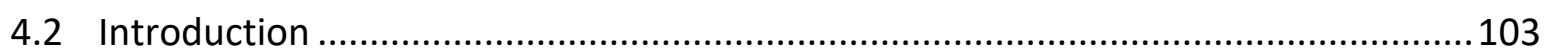

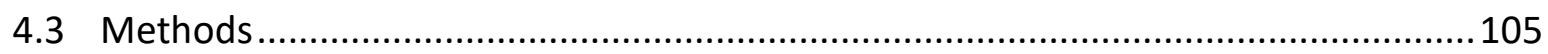

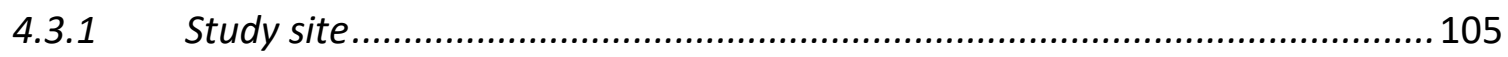

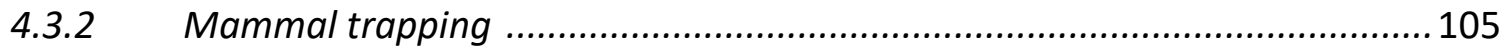

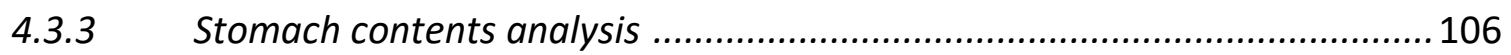

4.3.4 Data analysis of trap catch rates ............................................................107

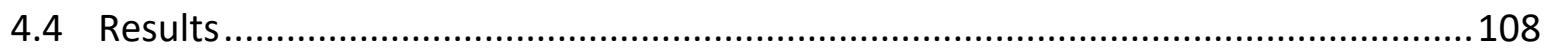

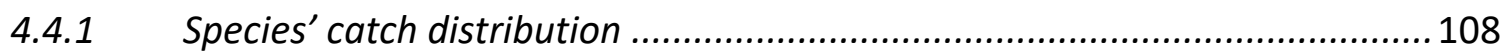

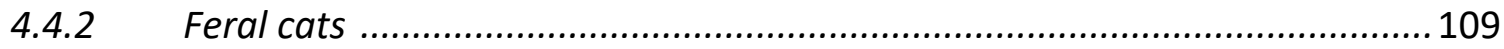

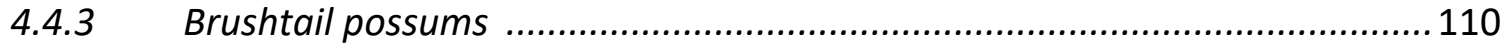

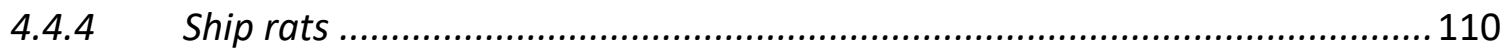

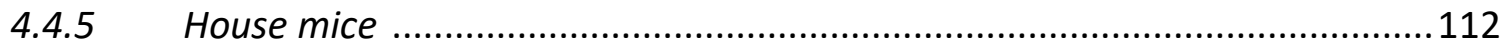

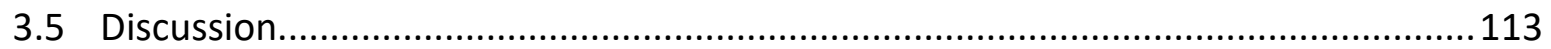

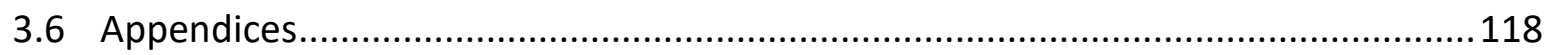

\section{Chapter 5 General discussion and management recommendations ....... 127}

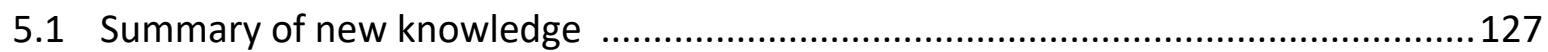

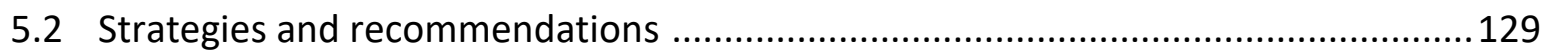

5.2.1 Reducing predation pressure from pest mammals ...................................... 129

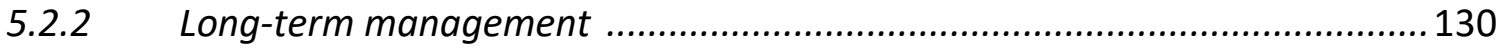

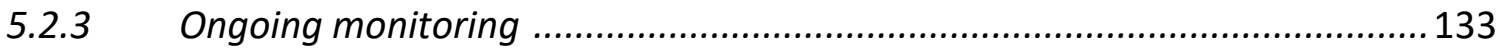

5.2.4 Boosting population numbers ............................................................... 134

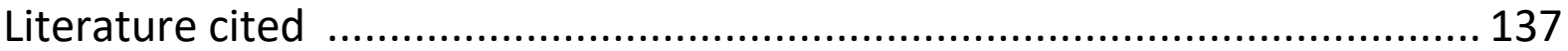




\section{List of Figures}

2.1 Study site 17

2.2 Change in monitoring plot gorse browse between 2005 and 2018 in the MGWSR ... 24

2.3 Change in monitoring plot gorse height between 2005 and 2018 in the MGWSR ..... 24

2.4 Change in monitoring plot gorse cover between 2005 and 2018 in the MGWSR ...... 25

2.5 Proportion of annual monitoring plots in each search time category .......................25

2.6 Average time till discovery per wētā over six monitoring years ................................26

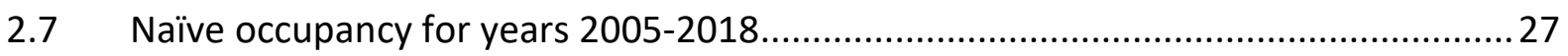

2.8 Estimated occupancy probability of MGW in the MGWSR for years 2005-2018........ 28

2.9 Estimated colonisation probability of MGW in the MGWSR between years 2005-2018 28

2.10 Estimated persistence probability of MGW in the MGWSR between years 2005-2018

2.11 Tracking index for rats, mice, possums, and hedgehogs in the MGWSR from October 2012 to October 2018 34

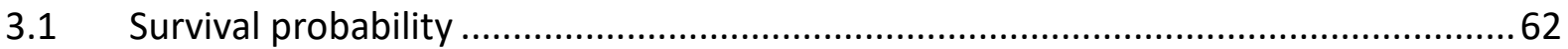

3.2 Average distance moved over 48 hours by MGW during radiotracking .................... 65

3.3 Net distance moved over two weeks by MGW during radiotracking .........................66

3.4 Average diffusion coefficients by season, habitat, and sex.......................................67

3.5 Average diffusion coefficients between seasons, habitats, and sex ..........................68

3.6 Example of radiotracked MGW movement pattern ................................................69

3.7 Example of moving window regression used to determine diffusion coefficients ..... 70

3.8 Average daily temperature effect on MGW average distance................................. 10

3.9 Height range of vegetation used by radiotracked MGW in gorse and native

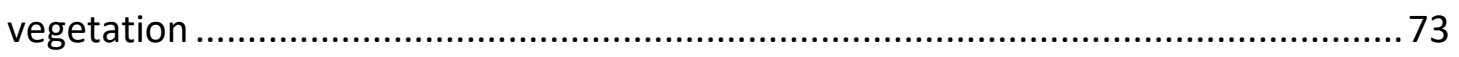

3.10 Height range of diurnal refuges within gorse and native vegetation..........................73

3.11 The range of gorse cover within $3.14 \mathrm{~m}^{2}$ of visually located radiotracked MGW diurnal refuges

3.12 Proportion of diurnal refuge sites in browsed, semi-browsed, or unbrowsed gorse during summer 2016/2017 and autumn and spring 2018 .75 
3.13 Proportion of radiotracked MGW diurnal refuges located in mahoe, tree fern, or on the ground during summer and autumn in native habitat.......................................76

3.14 Proportion of radiotracked MGW diurnal refuges located in gorse, ground fern, tree fern, Coprosma spp., foxglove, or on the ground during summer, autumn, and spring in native habitat.

4.2 Trap locations within the MGWSR. 107

4.3 Proportion of ship rats and house mice trapped as a function of trapping effort....109 


\section{List of Tables}

2.1 Summary of covariates used in MGW occupancy modelling .19

2.2 Summary of multi-season model selection for MGW population trajectory between 2005 and 2018

2.3 Summary of 2005 single-season model selection for MGW occupancy ...................... 31

2.4 Summary of 2005 single-season model selection for MGW detection .......................32

2.5 Summary of 2018 single-season model selection for MGW occupancy .....................32

2.6 Summary of 2018 single-season model selection for MGW detection ....................... 33

3.1 Summary of release categories, tracking seasons, sample sizes, and tracking period duration for MGW radiotracking.

3.2 Summary of Cox hazard regression model results .................................................62 62

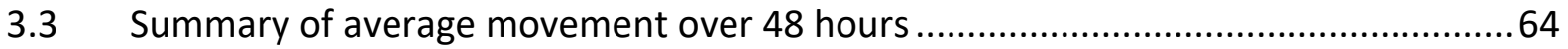

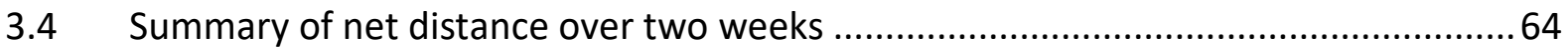

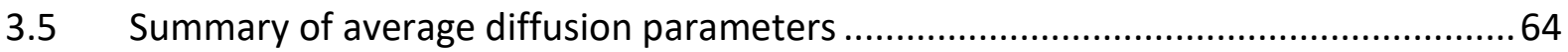

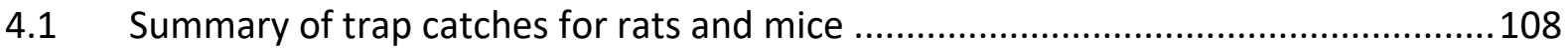

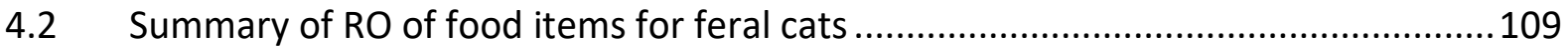

4.3 Summary of FOO and RO of food items for brushtail possums .............................110

4.4 Summary of FOO of invertebrates for brushtail possums ........................................110

4.5 Summary of FOO and RO of food items for ship rats ...........................................111

4.6 Summary of FOO of invertebrates for ship rats .................................................. 111

4.7 Summary of FOO and RO of food items for house mice ......................................112

4.8 Summary of FOO of invertebrates for house mice .............................................112 


\section{List of Appendices}

2.1 Naïve detection estimates from MGW annual monitoring....

2.2 Maximum search times applied to monitoring plots for years 2005 and 2014-2018

2.3 Gorse structure classification from Sutton (2004) ............................................... 44

2.4 Location of rodent monitoring tracking tunnels in the MGWSR ...............................44

2.5 Location of edge and interior monitoring plots in 2005 and 2018............................45

2.6 Monitoring plots where MGW were detected one, two, three, or four times ...........46

2.7 Change in the number of monitoring plots where one, two, three, or four MGW were

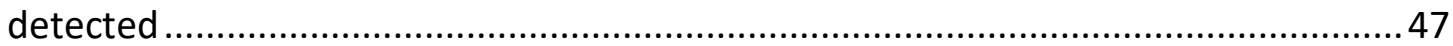

2.8 Simulation of the probability a MGW will remain inside a $3 \mathrm{~m}$ radius monitoring plot based on a random start position for a variety of step lengths....

2.9 Example of a MGW movement over five consecutive monitoring days, based on known autumn movement distances and patterns

3.1 Measurements of wētā taken to determine instar and size

3.2 Estimated size ranges of MGW instars in the MGWSR from Sherley and Hayes (1993) and Richards (1994)

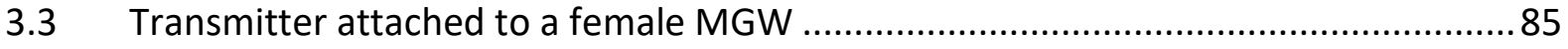

3.4 Summary of plot characteristics and example of gorse browse categories...............86

3.5 Summary of radiotracked wētā in summer 2016/2017, and autumn and spring 2018

3.6 Summary of MGW deaths due to causes other than predation ................................89

3.7 Movement of radiotracked MGW during summer, autumn, and spring ...................90

4.1 Summary of mammalian pest trapped in autumn and winter................................118

4.2 Trap locations where mammalian pests were caught...........................................121

4.3 Examples of invertebrate remains found in stomach contents .............................123

4.4 Comparison of ship rat and house mouse FOO for invertebrates ...........................125 
"If human beings were to disappear tomorrow, the world would go on with little change.... but if invertebrates were to disappear, I doubt that the human species could last more than a few months"

-Edward O. Wilson, 1978 



\section{Chapter 1 - General introduction}

Anthropogenic activity is the leading cause of ecosystem disruptions and the reduction or extinction of many species worldwide (Hoffmann et al., 2010). Extinction rates have largely accelerated over the past four decades due to habitat loss, disturbance, climate change, and the introduction of invasive species (Hoffmann et al., 2010; Cardoso et al., 2011). Conservative estimates approximate 3000 species' extinctions annually (Cardoso et al., 2011). Invertebrates constitute over $80 \%$ of the world's species and have important ecological roles as predators, prey, pollinators, disease vectors, herbivores, and detritivores in an array ecosystems (St Clair, 2011). Many species remain undescribed, however, invertebrates rival the proportion of vertebrates evaluated as endangered and critically endangered by the IUCN (International Union for Conservation of Nature; Cardoso et al., 2011). Despite the abundance and status of invertebrates, global conservation efforts have largely focused on more 'charismatic' vertebrate species such as birds and mammals resulting in largely unknown invertebrate extinction rates and a poor representation in the literature (Thomas et al., 2004; St Clair, 2011; Braby, 2017). New Zealand is one exception having a large number of highly endemic invertebrate species (St Clair, 2011), many of which are threatened, resulting in an increased contribution to invertebrate conservation worldwide, over the past few decades (for example see Bremner et al., 1984; Gibbs \& Mclntyre, 1997; Sherley, 1998; Brook, 1999; Gibbs, 2002; Fukami et al., 2006; Watts \& Thornburrow, 2009; Jones et al., 2013; Ruscoe et al., 2013). New Zealand studies have identified habitat loss and modification by browsers as concerns in invertebrate conservation, however, introduced mammalian predators, such as rats (Rattus spp.) and house mice (Mus musculus), are primarily implicated in the decline and extinction of many invertebrate species (St Clair, 2011).

\subsection{The impact of introduced mammalian predators on New Zealand invertebrates.}

New Zealand's distinct geological history led to native invertebrates evolving in the absence of terrestrial mammals, with the exception of three bat species (Chalinolobus tuberculatus, 
Mystacina tuberculata and M. robusta- extinct; Daugherty et al., 1993). As a result, gigantism, flightlessness, and ground-dwelling traits are common among taxa (Gibbs, 1998). Because New Zealand invertebrates co-evolved with avian and reptile predators, this led to behavioural and morphological anti-predator adaptations suited to evade visual hunters (Daugherty et al., 1993; Gibbs, 2010). Common adaptations include crypsis, whereby organisms use camouflage or nocturnality to avoid detection, and freezing, whereby organisms cease movement in the presence of predators to avoid being detected (Gibbs, 2010; Dent, 2016). These adaptations allowed large-bodied, flightless, and long-lived species to successfully survive in the presence of their natural predators (Gibbs, 2010).

The arrival of Polynesians to New Zealand in the $13^{\text {th }}$ Century resulted in the introduction of the first invasive mammal, the Polynesian rat or kiore (Rattus exulans; Wilmshurst et al., 2008). Ship rats ( $R$. rattus), Norway rats ( $R$. norvegicus), house mice, European hedgehogs (Erinaceus europaeus), brushtail possums (Trichosurus vulpecula), mustelids (Mustela spp.) and other mammalian pests were later introduced from 1769 with the arrival of European settlers (King, 2005a). These species have sensitive olfactory senses used to locate prey and combined, have largely suppressed or extirpated many native invertebrate populations (St Clair, 2011). As a result, invasive mammals, specifically rodents (Rattus spp. and M. musculus), mustelids, and possums, have been the primary focus of eradication and pest control programs in New Zealand (Parkes et al., 2017). Many offshore islands and fenced mainland reserves are now relatively pest-free (Russell \& Broome, 2016). Mainland populations are still largely prevalent despite control efforts, but are maintained at low numbers in some areas of the country (Russell \& Broome, 2016).

The three rodents, $R$. rattus, $R$. norvegicus, and $M$.musculus, have achieved almost global distributions, whilst R. exulans is widely distributed throughout the Pacific (Atkinson \& Towns, 2005; Innes, 2005a, 2005b; Ruscoe \& Murphy, 2005). Rodent species have particularly broad diets consisting of plant material, other small mammals, and invertebrates (Ruscoe et al., 2013). House mice are thought to consume a larger proportion of invertebrates than rat species (Miller \& Webb, 2001; Innes et al., 2014), however, Shiels et al. (2014) determined that invertebrates make up a substantial component (25-50\%) of all rodent diets. For example, invertebrate remains were found in $90 \%$ of mice stomachs, predominantly Lepidoptera, Coleoptera, and Araneae (Miller \& Webb, 2001). In addition, studies on 
Resolution and Breaksea Islands, found reduced diversity and declines of many indigenous invertebrates where Norway rats were present, compared to the neighbouring pest-free island in Fiordland (Bremner et al., 1984). Similarly, kiore were implicated, single-handedly, for the extinction of two large land snail species, Amborhytida tarangensis and Placostylus hongii on Lady Alice Island, which was evident through fossil shell records (Brook, 1999).

Brushtail possums are common in New Zealand due to the abundance of available food sources and lack of natural predators (Clout, 2002). However, possum control has been conducted nationwide since the 1950's due to the threat possums pose to New Zealand's primary industries, as carriers of bovine tuberculosis (TB), in addition to direct consumption of native biota (Warburton \& Livingstone, 2015). Possums are predominantly herbivorous, but have been found to additionally consume invertebrates to meet dietary protein requirements (Nugent et al., 2000). Species of Phasmatodea, Orthoptera, Hemiptera, Coleoptera, and Dipetera have been previously identified in possum faeces (Nugent et al., 2000 ) with invertebrate remains found in $48 \%$ (with the above mentioned Orders contributing to approximately $80 \%$ of pellets) of 2596 possum faecal pellets analysed from the Orongorongo Valley, Wellington (Cowan \& Moeed, 1987).

Mustelids (stoats (Mustela erminea), weasels ( $M$. nivalis), and ferrets ( $M$. furo)) were introduced to New Zealand as a biocontrol for rabbits (Oryctolagus cuniculus), however, native fauna quickly became mustelid targets resulting in widespread populations (Clapperton \& Byrom, 2005; King, 2005b; King \& Murphy, 2005). All mustelid species predominantly prey on mammals and birds, but will hunt anything available to them including lizards, invertebrates, and aquatic fauna (Murphy et al., 2008). However, stoats and weasels are more likely to consume invertebrates than the much larger ferret (Murphy et al., 2004). Invertebrates were recorded in $52 \%$ of stoat and $55 \%$ of weasel stomachs in the Bay of Islands and south Westland, respectively (Murphy et al., 2008; Strang et al., 2018), compared to in only $10 \%$ of ferret stomachs in the Mackenzie Basin (Murphy et al., 2004).

Hedgehogs are widespread throughout New Zealand and primarily insectivorous (Jones et al., 2005), but have only recently been identified as a significant predator of native invertebrates and lizards (Jones et al., 2013). The main groups targeted by hedgehogs include Coleoptera, Lepidoptera, Dermaptera, Hymenoptera, and Orthoptera (Campbell, 1973; Jones et al., 2005). An examination of 58 hedgehog faecal samples from Macraes Flat found 55\% and 34\% 
contained beetle and wētā remains, respectively (Jones et al., 2005; Jones et al., 2013). Mammalian predators have generally had a negative impact on invertebrate populations in New Zealand, but particularly so on larger-bodied species such as wētā (Watts et al., 2012).

\subsection{New Zealand Wētā}

New Zealand wētā are one such group of endemic invertebrates that have declined in the presence of introduced mammals. Wētā belong to the Orthopteran order containing grasshoppers, katydids, crickets, and locusts (Field, 2001). Two distinct families exist therein, Anostostomatidae and Rhaphidophoridae, containing over 70 species within New Zealand (Sherley, 1998). Anostostomatidae contains giant wētā (Deinacrida), ground wētā (Hemiandrus), tusked wētā (Motuwētā and Anisoura), and tree wētā (Hemideina: Gibbs, 2001). Cave wētā are part of Rhaphidophoridae, a separate taxonomically diverse family, containing many genera (Field, 2001). All wētā are flightless and nocturnal and most species are large-bodied (35-75mm; Watts et al., 2008). Species inhabit a variety of niches, from alpine ranges to lowland forests, and fulfil roles as predators, scavengers, or herbivores (Sherley, 1998; Dent, 2016). During the day, wētā take refuge in vegetation or tree cavities (McGuinness, 2001). Most activity occurs at night consisting of feeding, mating, relocating to new refugia, and egg oviposition in soil by females (Richards, 1994; Dent, 2016). It is during this time that wētā are vulnerable to introduced mammalian predators (Gibbs, 1998).

Wētā generally display K-selected traits such as longevity (adults live for one - three years) and slow reproductive performance (eggs take on average six-eight months to develop; Gibbs, 1998; Mclntyre, 2001). However, they do have high fecundity, each female producing 200400 eggs (Stringer, 2001). Native predators of wētā in New Zealand include diurnal species kaka (Nestor mariodionalis), harrier hawk (Circus approximans), and saddleback (Philesturnus carunculatus), and nocturnal species tuatara (Sphenodon spp.), kiwi (Apteryx spp.), shorttailed bat (Mystacina tuberculate), morepork (Ninox novaeseelandiae), and laughing owl (Sceloglaux abifacies - extinct; Gibbs, 1998). These species are primarily visual and/or auditory hunters, and thus wētā defences such as freezing, crypsis, abdomino-femoral 
stridation, and raising hind legs over body are somewhat effective allowing populations to persist (Daugherty et al., 1993; Sutton, 2004).

The historic distribution of wētā in New Zealand is not well understood, but there is evidence that giant wētā species $D$. heteracantha and $D$. rugosa were once common on the mainland, now restricted to a few offshore islands (Sherley, 1998; Gibbs, 2001). The decline of wētā on the mainland has been attributed to predation by mammalian pests, habitat modification by introduced browsers, and habitat destruction for agricultural purposes (Sherley, 1998). Approximately $50 \%$ of all wētā species, particularly giant and tusked wētā, are classified as threatened, at risk, or data deficient under the New Zealand threat classification system (Trewick et al., 2016).

Wētā have had variable success at persisting in the presence of introduced mammalian predators. Tree wētā (Hemideina spp.) remain relatively common throughout New Zealand (Watts et al., 2017), and are found in lowland habitat where they coexist with mammalian predators (Gibbs, 1998; Watts et al., 2017). Small diurnal galleries and behavioural adaptations, such as short foraging trips and mostly arboreal movement, are thought to be key to their success (Gibbs, 1998). However, mainland populations are still supressed by mammals and rats in particular (Gibbs, 1998; Watts et al., 2008). For example, dramatic increases in Auckland tree wētā (H. thoracica) were recorded following mammal eradication from Sanctuary Mountain Maungatautari (Watts et al., 2011). Rufaut and Gibbs (2003) noted a similar case where $H$. crassidens behaviour became more 'relaxed' and population densities increased significantly from 4.4 to $6.9 \mathrm{wētā} / \mathrm{m}^{2}$ following the eradication of rats from Nukuwaiata Island, Cook Strait.

Lowland-inhabiting giant, tusked, and ground wētā are at the other extreme, being highly vulnerable to predation by mammalian species (Gibbs, 1998). These species generally spend much more time near the ground or have easily accessible refuges (Gibbs, 1998). Large declines of Hemiandrus spp. have linked to hedgehog presence and one study in the upper Waitaki Basin found Hemiandrus spp. and Hemideina maori remains in $22 \%$ of hedgehog stomachs, one stomach containing 283 Hemiandrus legs indicating at least 47 wētā had been consumed (Jones et al., 2005). Rattus spp. have been attributed to extinction of $D$. heteracantha from the mainland and two large islands of New Zealand, as the species is currently restricted to the pest-free Little Barrier Island (Gibbs, 2001; Watts \& Thornburrow, 
2011). Despite some evidence, there is still uncertainty around the impact of introduced mammals on local wētā populations (Miller \& Webb, 2001). The presence of mice in otherwise mammalian pest-free sanctuaries, such as Zealandia, Wellington, is providing some insight to the impact of mice alone on wētā. Mice were found to supress the $D$. rugosa population on Mana Island (Wellington; McIntyre, 2001), and their impact on juveniles and eggs is unknown (Watts et al., 2012). However, adult D. rugosa translocated to Zealandia were found to be largely unaffected by low densities of mice, despite periodic outbreaks (Watts et al., 2012). Understanding which pest species are causing more damage to local populations is valuable for informing targeted control operations (Shiels et al., 2013). The Mahoenui giant wētā is one example where its habitat is thought to aid the species survival in the presence of mammalian predators, but to what degree is unknown.

\subsection{The Mahoenui giant wētā}

The Mahoenui giant wētā (MGW; Deinacrida mahoenui) is the only giant wētā species still naturally present on the North Island mainland of New Zealand (Gibbs, 2001). MGW were discovered in the King Country in the 1960's inhabiting remnant tawa (Beilschmiedia tawa) forests and patches of the introduced, woody shrub, gorse (Ulex europaeus) in the area (Richards, 1994; Watts et al., 2013). The largest remaining population is now restricted to an 187ha block of farmland that is dominated by gorse, approximately $3.5 \mathrm{~km}$ east of Mahoenui (Watts et al., 2013). The gorse is believed to have provided refuge for the wētā in the presence of mammalian predators, as well as shelter and a food source (Richards, 1994; Watts \& Thornburrow, 2009). The Department of Conservation (DOC) purchased the land in 1990 and gave it scientific reserve status (Mahoenui Giant Wētā Scientific Reserve; MGWSR) to protect the wētā (Richards, 1994). A second population was known from near Otangiwai, but is presumed extinct after the removal of native bush for agricultural purposes (Watts \& Thornburrow, 2009).

The population size of MGW in the MGWSR is unknown. The cryptic and nocturnal nature of the wētā make them difficult to locate, thus no estimates have been made (Watts \& Thornburrow, 2009). The species is considered 'at risk- recovering' under the New Zealand threat classification system (Trewick et al., 2016), and has been included in the top 150 
priority species in New Zealand's threatened species strategy draft (DOC, 2017). Siteoccupancy modelling, a monitoring tool that estimates the probability of wētā presence within established plots (Sutton, 2004), has been used since 2005 to monitor MGW population dynamics, providing occupancy comparisons between years (MacKenzie, 2012). Raw detection data suggests MGW numbers in the reserve have slowly declined since 2011 (DOC, 2016a; Chapter 2). Numerous translocations have been attempted since 1989, with over 2000 MGW being moved to seven locations (five with and two without mammalian pests present; Watts \& Thornburrow, 2009). Two of the translocations to pest-free or near pestfree sites successfully established (Mahurangi Island Scenic Reserve, and Warrenheip private land; Watts \& Thornburrow, 2009). In 2012 and 2013, 200 MGW were translocated into the pest-free tawa-dominated forest at Sanctuary Mountain Maungatautari (Watts, 2012, 2013). Recently, adults have been observed so it is assumed the population is establishing successfully in the absence of mammals (C Watts, pers. comm., 2019).

Over the recent decades the Mahoenui Giant Wētā Scientific Reserve has been reverting to native vegetation through natural succession (Sullivan et al., 2007), despite management initiatives, such as maintaining a population of feral goats, implemented to slow the successional process. Gorse is naturally an early successional plant that provides ideal microhabitats for native broadleaf saplings (Wotton \& McAlpine, 2013). Of the reserves three valleys, the southernmost is already completely dominated by native trees and ferns such as mahoe (Melicytus ramiflorus), tree fern (Cyathea spp. and Dicksonia fibrosa), kanuka (Kunzea ericoides), and Coprosma spp. (Richards, 1994: DOC, pers. comm., 2016). Over recent years, tree ferns and ground ferns have become noticeably more abundant throughout the gorsedominated middle and northern valleys (Quinnell, 2015; DOC, 2016a). It has been suggested that the lack of spiny, dense foliage in the native plant species may expose wētā to higher levels of predation than in the gorse (Watts \& Thornburrow, 2009).

\subsubsection{MGW management and research to date.}

The management of other giant wētā species has largely concerned sites that are relatively pest-free or where native vegetation is present (see (Gibbs, 1998; Watts et al., 2008; Watts \& Thornburrow, 2011). The MGWSR is the only habitat where invasive species - gorse and feral 
goats (Capra hircus), are protected to aid the survival of wētā in the presence of mammalian predators (Richards, 1994; Gibbs, 2001). Management at the MGWSR has been relatively minimal. Large numbers of goats are maintained within the reserve to browse the gorse (Jowett \& Plant, 1988), that keeps the prickly foliage dense below one metre, increasing protection for wētā from mammalian predators (Sherley \& Hayes, 1993; Watts \& Thornburrow, 2009). However, despite efforts to maintain a gorse-dominated habitat, young gorse recruitment is low within the reserve and browsing has not been enough to prevent succession (Sutton, 2004).

Gorse is also highly flammable during the summer when foliage dies off, posing a threat to the MGWSR population (Richards, 1994). To mitigate the risk of population loss due to fire, fire breaks are maintained between valleys, effectively splitting the reserve into three (Quinnell, 2015). Cattle and sheep are farmed within the reserve for part of the year to keep pasture down and open up the gorse to encourage recruitment (Sutton, 2004; Watts et al., 2008). Pest control in the area has been irregular and focused specifically on possums to mitigate the spread of TB with control operations occurring in 2005, 2010, and 2016 removing large numbers of possums (P Bird, pers. comm., 2018). However, the effect on the MGW population is unknown (Quinnell, 2015; DOC, 2016b).

Research has been conducted on Mahoenui giant wētā life history, activity, diurnal refuge use, reproductive biology, and monitoring techniques and trends (Sherley \& Hayes, 1993; Richards, 1994; Sutton, 2004; Watts \& Thornburrow, 2009). Captive rearing has been attempted twice and proved successful (Richards, 1994; Sherley, 1998). Richards (1994) extensively studied the giant wētā's ecology and behaviour in captive settings. Predation of the Mahoenui giant wētā has only been recorded on four occasions, where the predators were a ship rat, hedgehog, possum, and harrier hawk (Jowett \& Plant, 1988; Jowett, 1991). In 2004, Sutton (2004) established the site-occupancy modelling methods and monitoring plots within the MGWSR which have since been used by DOC to monitor population dynamics. These studies provide crucial information about the ecology of the species, but information gaps still exist, such as survival rates, movement patterns, and diurnal refuge use in native vegetation, and potential predators in the MGWSR. These knowledge gaps need to be addressed in order to inform future management and conservation decisions. 


\subsection{Thesis objectives}

The overall objective of this thesis is to improve the understanding around the MGW population in the MGWSR by filling existing knowledge gaps so that informed management decisions can be made in the future. The three data chapters in this thesis (Chapters 2, 3, and 4) were written as standalone manuscripts, and consequently some repetition exists between them.

Chapter 2 explores changes to the MGWSR's gorse mosaic and the MGW population 14-years after the establishment of annual site-occupancy monitoring. The state of the reserve's gorse habitat has not been formally evaluated in recent years. Assessment of the MGW population trajectory builds directly on work by MacKenzie (2012). The population was considered stable between 2005 and 2012 (MacKenzie, 2012), but new site-occupancy data (unanalysed) suggests this status may have changed. MacKenzie (2012) also assessed the effect of abiotic covariates, such as gorse structure, plot location, weather etc., on MGW occupancy and detection probabilities in 2005. Multi-season models were used for this analysis assuming covariate values remained constant over the eight years (MacKenzie, 2012). We believe this is an unreasonable assumption given the significant changes found after 14-years. This chapter determines whether the MGW population remains stable or has declined in recent years and reassess the effect of abiotic covariates on occupancy and detection probabilities in 2005, in addition to 2018, using single-season models. Furthermore, we explored mammalian pest dynamics within the reserve over the past seven years.

Chapter 3 explores MGW survival rates, movement patterns, and diurnal refuge use in both gorse and native vegetation using radiotelemetry. Survival rates of MGW are unknown, having never been assessed, but are important for determining how wētā will cope in the presence of mammalian predators if natural succession is left to take its course. For this aim we expect wētā survival rates will be higher in gorse habitat. In-situ MGW behaviour has previously been studied (see section 1.4.1), but not in native vegetation. Knowledge of movement patterns and diurnal refuge use is important for informing management, monitoring, and translocation of wētā. 
Chapter 4 aims to identify potential mammalian predators of the MGW within the MGWSR. An array of mammalian pests are present within the reserve, but their roles as predators of the MGW within the gorse habitat is somewhat unknown.

The findings from chapters 2,3 , and 4 are used to discuss population and site management strategies, with the intention of informing future initiatives to help secure the long-term survival of this species (Chapter 5 ).

\subsection{Author's contribution and permits}

The material contained within this thesis was collected, analysed, and written by myself (Hannah Stilborn), with the exception of the following: (1) The overall research plan and methods were developed with the assistance of Amanda Haigh, Lucy Bridgman, Abi Quinnell, Jessica Scrimgeour, Tertia Thurley (All DOC), Stephen Hartley (Victoria University of Wellington), Corinne Watts, and Danny Thornburrow (both Manaaki Whenua - Landcare Research). (2) All data collected during annual monitoring of MGW between 2005 and 2018 was provided by DOC (Chapter2). (3) Considerable advice was provided by Darryl Mackenzie (Proteus wildlife research consultants) for occupancy modelling analysis (Chapter 2). (4) Summer survival, movement, and diurnal refuge use data was collected by myself during a summer research scholarship run and funded by DOC and VUW (Chapter 3). (5) Corinne Watts, Danny Thornburrow, DOC Maniapoto staff (Thomas Emmit, Tom Quinnell, Abi Quinnell, Antoinette Wilson, Athena Irvine, Sarah Tunnicliffe), DOC Pureora staff (Liesl Van Wyk, Leigh Roderick, Logan Moore, Eliska Blattner-De Vries, Harriet Kemp, Bernie Buhler), DOC Taupo (Amanda Haigh), DOC Turangi (Jessica Scrimgeour), Otorohanga Kiwi House staff (Greta Horne, John Malan, Danielle Hawkins), Garry Coles, Ngatai and Hemi Rauputu, William Wetere, Bryce, Rachel and Ben Stilborn, University of Waikato summer scholars Karina Radley and Callum Parker, and Lynette Adams provided support with field work (wētā collection, transmitter attachment, and radiotracking). (6) Bernie Buhler (DOC) ran the trapping operation of possums and feral cats (Chapter 4). (7) Corinne Watts and Scott Bartlam (MWLR), and Stephen Thorpe (Independent researcher) identified invertebrate remains in 
stomach contents (Chapter 4). (8) Stephen Hartley and Corinne Watts provided substantial commentary on all chapters.

All methods used in this thesis were approved by the Victoria University of Wellington animal ethics committee (VUW AEC 0000025062), DOC (60994-FAU), and Mokau Ki Runga Regional Management Committee. Site access was approved by DOC and private land owners. 



\section{Chapter 2 - The status of a giant wētā population (Deinacrida mahoenui) in a gorse dominated reserve}

\section{$2.1 \quad$ Abstract}

The last remaining individuals of the original Mahoenui giant wētā (MGW; Deinacrida mahoenui) population are currently restricted to an 187ha mainland reserve (Mahoenui Giant Wētā Scientific Reserve; MGWSR) in Mahoenui, western King Country, New Zealand. Having sought refuge in the introduced woody shrub, gorse (Ulex europaeus), these wētā have survived in the presence of introduced mammalian predators for almost six decades. Due to natural succession, the reserve is gradually reverting to native bush and annual monitoring data shows potential signs of population decline. We used 14 years' of monitoring data to explore changes to the reserve's gorse habitat and MGW population between 2005 and 2018. We additionally assessed the effect of abiotic covariates, such as gorse structure, plot location, weather etc., on MGW occupancy and detection probabilities in 2005 and 2018. Furthermore, we assessed mammalian pest population dynamics within the reserve over the past seven years. Gorse within the reserve was found to have significantly changed since 2005. Unbrowsed, tall bushes are now dominant, which may provide less protection to MGW. The 14-year population trajectory revealed the MGW population has been declining since 2012. This result was consistent with naive occupancy estimates and the increased time until discovery per wētā ( 0.3 hours/year), suggesting MGW are not as abundant and easily found as they were in 2005. The covariate 'location' was identified as an important for predicting MGW occupancy in 2018, whereby plots in edge habitat, potentially preferred or safer, were more likely to be occupied. Mammalian pests, rats (Rattus spp.), house mice (Mus musculus), brushtail possums (Trichosurus vulpecula), and European hedgehogs (Erinaceus europaeus), were found to be present within the reserve year-round, peaking in summer and autumn. These findings provide an overall picture of the state of the Mahoenui reserve and giant wētā population, from which we make short and long-term management recommendations and suggest areas for future research. 


\subsection{Introduction}

Despite their abundance, richness, and importance to ecosystems worldwide, invertebrates are largely neglected in conservation and management efforts (Cardoso et al., 2011a). Their lack of charismatic appeal compared to more popular vertebrate species has resulted in little conservation consideration and a poor representation in the literature (St Clair, 2011; Braby, 2017). However, in part due to the large number of endemic species, invertebrate conservation awareness in New Zealand has greatly increased over the past few decades (St Clair, 2011). Numerous tools, such as pitfall traps (Seldon \& Beggs, 2010; Watts et al., 2011b), frass drop collection (Sweetapple \& Barron, 2016), artificial refuges (Rufaut \& Gibbs, 2003; Bowie et al., 2014), miniature transmitters (Watts et al., 2012; Liegeois et al., 2016), tracking tunnels (Watts et al., 2008b; Watts et al., 2011a; Watts et al., 2013), and manual search techniques such as mark-recapture (Jamieson et al., 2000), exist that enable much needed ecological and behavioural information to be collected from a range of invertebrate species (Cardoso et al., 2011b). Long-term monitoring projects that assess population trajectories over many years are rarely used for invertebrates, but provide critical information that can be used to identify conservation issues and manage threatened or at risk populations (Cardoso et al., 2011b; Zografou et al., 2017). For example, artificial refuge monitoring over four years allowed conservation managers to assess the impact of kiore (Rattus exulans) eradication on a local Wellington tree wētā population (Hemideina crassidens) in the Pelorus Sound, New Zealand (Rufaut \& Gibbs, 2003), and 18-years' of monitoring data for an extremely rare butterfly (Speyeria idalia) in Pennsylvania, USA, provided a long-term population trajectory informed by active conservation management (Zografou et al., 2017).

The Mahoenui giant wētā (MGW; Deinacrida mahoenui) is another at risk invertebrate species that has been monitored for the past 14-years by the Department of Conservation (DOC). The last remaining individuals of the original population are restricted to an 187ha mainland reserve (Mahoenui Giant Wētā Scientific Reserve; MGWSR) in Mahoenui, western King Country, New Zealand (Watts et al., 2013). The introduced woody shrub gorse (Ulex europaeus) dominates the majority of the reserve. Its spiny, dense foliage is thought to provide refuge to these wētā, allowing the population to successfully survive in the presence 
of mammalian predators for almost six decades (Sherley \& Hayes, 1993; Stronge et al., 1997; Watts \& Thornburrow, 2009).

Annual monitoring (manual searches at established plots) has been conducted since 2005 within the MGWSR's gorse habitat (Sutton, 2004). This data has allowed DOC to observe MGW population trends, providing an approximate indication of stability or decline. Over the past six - 10 years there have been concerns raised regarding the long-term survival of the species as unanalysed detection estimates (Appendix 2.1) and other sporadic monitoring conducted by Manaaki Whenua - Landcare Research suggest the population may be declining (Quinnell, 2015). In addition, the gorse habitat is gradually reverting to native bush due to natural succession (Sullivan et al., 2007). Of the reserve's three valleys, the southernmost is already completely dominated by native trees and ferns, and in recent years tree ferns (Dicksonia fibrosa and Cyathea spp.) and ground ferns have become noticeably more present throughout the northern and middle valleys (Richards, 1994; DOC, pers. comm., 2016). The lack of protective foliage in the native vegetation and lack of consistent mammal control at MGWSR may expose wētā to higher levels of predation (Watts \& Thornburrow, 2009), leading to further decline.

Over 2000 MGW have been translocated to seven sites during 32 releases (see Watts \& Thornburrow, 2009). However, only wētā translocated to the two pest-free and near pestfree sites successfully established. A more recent translocation to the predator-free Sanctuary Mountain Maungatautari was undertaken in 2012 and 2013, but the status of this population is unknown (Watts, 2012, 2013). It is therefore important to understand the status of the Mahoenui population so that appropriate management responses can be initiated.

Site-occupancy modelling allows the population trajectory of cryptic or rare species, such as the MGW, to be assessed when the probability of detection is less than one (Mackenzie et al., 2002). Researchers are able to account for non-detection of a species which is not accounted for when visualising the naïve occupancy (MacKenzie et al., 2002). Site-occupancy modelling has been used for a range of species and purposes including nest site selection of South Georgian Diving Petrels (Pelecanoides georgicus) on Codfish Island, New Zealand (Fischer, 2016), amphibian richness and occupancy in seasonal wetlands in the Prairie Pothole region, USA (Balas, 2008), and the effect of habitat covariates on bird occupancy for multiple 
species in California, USA (Wood, 2007). Occupancy modelling has also been applied to invertebrates, for example, determining the habitat use and detectability of the hops azure butterfly (Celastrina hummulus) in Colorado, USA (Puntenney \& Schorr, 2016).

In this study, we used 14 years' of monitoring data collected by DOC to explore changes to the MGWSR gorse mosaic and model the trajectory of the MGW population in the MGWSR. The model provided occupancy, colonisation and persistence estimates that indicate the stability or decline of the population. We additionally assessed the effect of abiotic factors on the occupancy and detection probabilities of MGW in 2005 and 2018. Furthermore, we assessed mammalian pest population dynamics within the reserve using tracking tunnel data collected by DOC over the past seven years

Henceforth, Mahoenui giant wētā will be referred to as MGW or wētā. Other species will be referred to by their full common name and/or scientific name e.g. Auckland tree wētā (Hemideina thoracica).

\subsection{Methods}

\subsubsection{Study site}

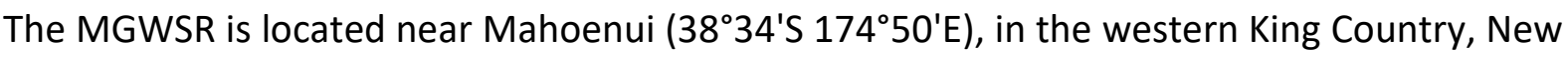
Zealand (Fig. 2.1). The 183.7ha reserve contains three distinct valleys separated by firebreaks. Gorse, an introduced woody shrub, currently dominates the northern and middle valleys, with tree ferns (Dicksonia fibrosa and Cyathea spp.) and ground ferns becoming increasingly abundant due to natural succession. The southern valley is at a more advanced stage of succession, dominated by species such as mahoe (Melicytus ramiflorus), tree ferns, kanuka (Kunzea ericoides), divaricating Coprosma (Coprosma spp.), wild passion vine (Passiflora tetrandra), muehlenbeckia vine (Muehlenbeckia australis), and many ground fern species (Richards, 1994; DOC, pers. comm., 2016). Farmland surrounds the reserve and there is no regular pest control except for occasional possum control for bovine tuberculosis (TB) management. Feral goats are also maintained within the reserve with the intention of browsing the gorse, keeping it dense which is thought to provide better protection for wētā. 

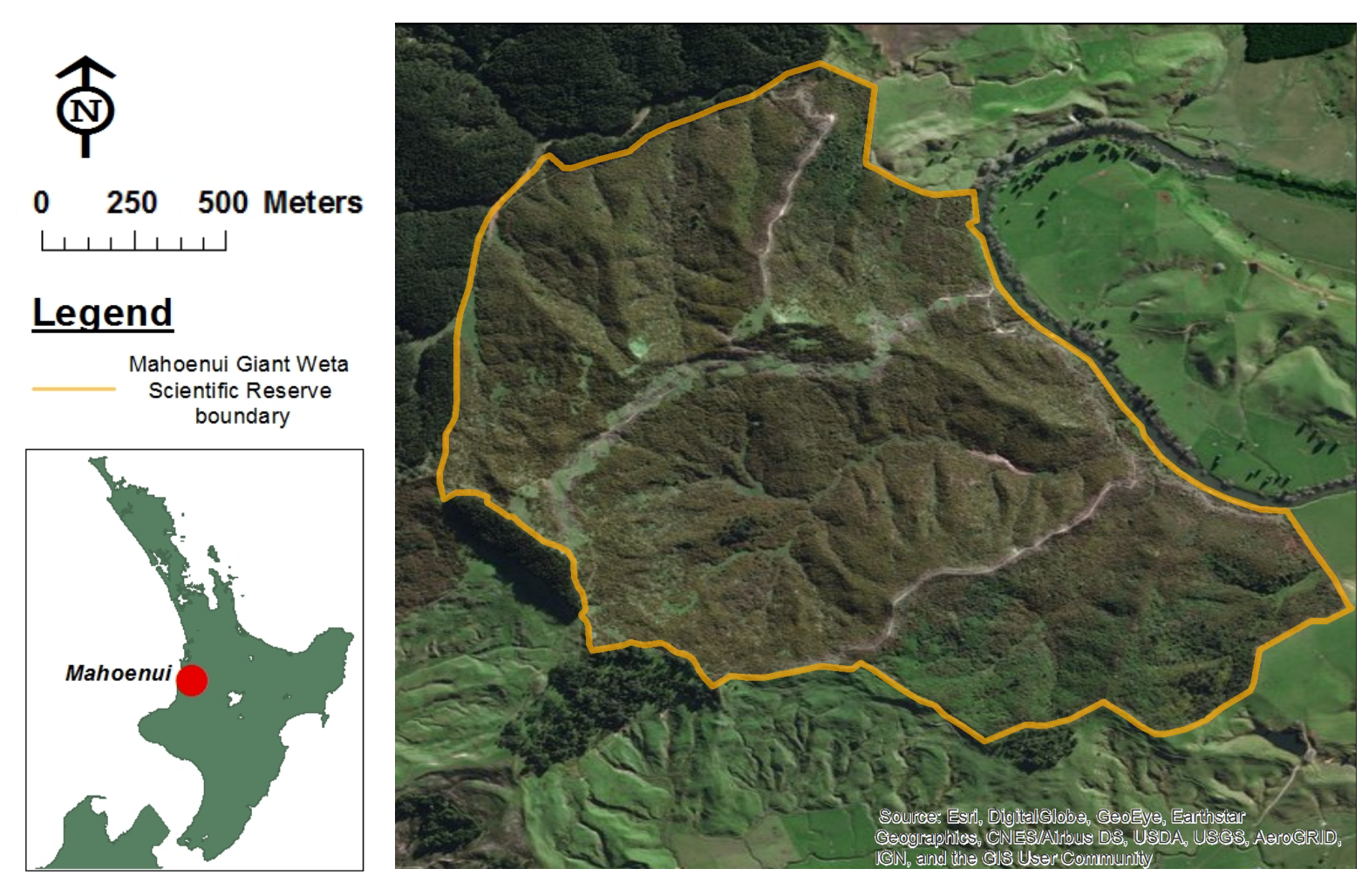

Figure 2.1 Map of the Mahoenui Giant Wētā Scientific Reserve (MGWSR). Orange outline indicates the reserve boundary.

\subsubsection{Annual monitoring data}

Annual monitoring data (site-occupancy) of MGW from 2005 to 2018 was provided by DOC Maniapoto. Between 55 and $82 \mathrm{3m}$ radius plots were established in the gorse dominated valleys (northernmost and middle) and were searched for MGW in autumn (March) each year. Each plot (or site), was allocated a maximum search time (5 - 20mins) based on the gorse cover and density within the plot (Appendix 2.2). However, if a MGW was found within the allocated time, searching stopped and the search time was recorded (see Sutton (2004) for more detail). Plots were sectioned into quarters and searched from top to bottom (no higher than $2 \mathrm{~m}$ ) by carefully pulling apart the vegetation (Sutton, 2004). Each plot was searched approximately three times over five consecutive days (the survey period), each time by a different observer. Observers varied between years with a total of 31 different observers searching between 2005 and 2018. Wētā presence, observer name, and weather information were recorded for each plot search. In 2005 and 2018, additional site characteristics: topography, gorse browse (Appendix 2.3), percentage gorse cover, gorse height, other 
vegetation types present were recorded. These variables were used as covariates in all MGW occupancy modelling (Table 2.1).

\subsubsection{Mammal monitoring data}

Mammal monitoring data from October 2012 - October 2018 was provided by DOC Maniapoto. Monitoring was completed two - five times a year in varying months using 30 tracking tunnels containing two pieces of paper on either side of an inkpad. Tunnels were split over the three MGWSR valleys so that each of the lines contained 10 tunnels, approximately $100 \mathrm{~m}$ apart (Appendix 2.4). Peanut butter was used as bait at either end of the tunnels. The focus was to gain a tracking index for rodents, however, possums and hedgehogs regularly interfered so were also recorded (Quinnell, 2015). The tracking index is calculated as the percentage of tunnel cards where the species' prints are present after one night (Gillies \& Williams, 2013).

\subsubsection{Data analysis}

Change in the gorse habitat between 2005 and 2018 was assessed using generalized linear mixed-effects models with Binomial distribution. Gorse type, gorse height, and gorse cover from annual monitoring data (available for years 2005 and 2018 only) were defined as the dependant variables in separate models with year as a fixed effect. Due to repeated measures of some monitoring plots, the variable 'plot' was defined as a random effect in these models. The covariates 'gorse type' and 'gorse height' had three levels (browsed, semi-browsed, and unbrowsed; $<1 \mathrm{~m}, 1-2 \mathrm{~m}$, and $>2 \mathrm{~m}$, respectively), but level 'browsed' and ' $<1 \mathrm{~m}$ ' were excluded from analysis due to too few plots containing browsed $<1 \mathrm{~m}$ tall gorse. The covariate 'gorse cover' has four levels $(0-24 \%, 25-49 \%, 50-75 \%$, and $>75 \%)$ that were analysed using six pairwise models. As no significant difference was found between the two lower cover levels (0$24 \%$ and $25-49 \% ; z=0.413, p=0.68)$ and the two higher cover levels $(50-75 \%$ and $>75 \% ; z=-$ 1.029, $p=0.303)$, we redefined the four levels into two; 'low cover' (0-49\%) and 'high cover' (50-100\%). We additionally tested for change in the number of monitoring plots allocated to each of the search time categories (5, 10, 15, and 20 minutes) over time (2005 and 2014 - 
2018) using a generalised linear model with Poisson distribution. Data was not available for years $2006-2013$.

Table 2.1 Summary of covariates used in all MGW occupancy models. Site-specific refers to covariates that are specific to each site and constant throughout a specific survey or year. Survey-specific refers to covariates that are variable throughout a specific survey or year.

\begin{tabular}{|c|c|c|}
\hline Covariate type & Covariate name & Covariate Description \\
\hline & . & Constant for all sites or survey periods. \\
\hline & Day & The specific day within a survey period. ( $n=5$ per Year) \\
\hline & Year & A specific survey period from 2005 to 2018 ( $n=14)$. \\
\hline & Trend & The linear effect of between survey periods (years). \\
\hline \multirow[t]{12}{*}{ Site-specific } & Browse & Structure of a gorse bush within a plot defined by three \\
\hline & & categories - Browsed, semi-browsed, and unbrowsed. See \\
\hline & & Appendix 2.3 for further definitions. \\
\hline & Topography & The position of the plot in the MGWSR defined by three \\
\hline & & categories - Face, ridge, and gully. \\
\hline & Height & The height $(m)$ of the gorse bush within a plot defined by \\
\hline & & Three categories - low $<1 \mathrm{~m}$, medium $1-2 \mathrm{~m}$, and high $>2 \mathrm{~m}$. \\
\hline & Cover & The percentage of gorse cover within a plot defined by \\
\hline & & four categories $-0-25 \%, 25-49 \%, 50-75 \%$, and $>75 \%$. \\
\hline & Location & The location of the monitoring plot in the MGWSR defined \\
\hline & & by two categories - edge and interior. See Appendix 2.45 \\
\hline & & for further definitions. \\
\hline \multirow[t]{5}{*}{ Survey-specific } & Observer & The searcher of a particular plot on a particular day during \\
\hline & & a survey period. $n=35$ over the 14 -year period. \\
\hline & Weather & The local weather while searching a particular plot on a \\
\hline & & particular day during a survey period defined by four \\
\hline & & categories - Fine, overcast, light rain, and moderate rain. \\
\hline
\end{tabular}


Search times and the number of wētā found per year were calculated from annual monitoring data. No data was available from 2006 through to 2013. A generalised linear mixed-effects regression model with Poisson distribution was used to model the change in time till wētā discovery per unit effort (varied observers) between years. The rate at which wētā were discovered (number of wētā found offset by the number of hours spent searching) was defined in the model as the dependant variable with year as a fixed effect.

All models were run in R version 3.5.1 (R Core Team, 2018) using packages Ime4 (Bates et al., 2015), ImerTest (Kuznetsova et al., 2017), and multicomp (Hothorn et al., 2008). P-values were considered significant when $\alpha<0.05$ ( $95 \%$ confidence).

\subsubsection{Occupancy modelling}

To assess the MGW population trajectory from 2005-2018, multi-season, single-species occupancy models were developed and analysed using programme PRESENCE version 2.12.24 (Hines, 2006). Multi-season (or multi-year) models consist of four probability components, occupancy $(\boldsymbol{\Psi})$, detection (p), colonisation (Y), and extinction ( $\boldsymbol{\varepsilon}$ ) (MacKenzie et al., 2003). In terms of the MGW population, occupancy is defined as the probability MGW are occupying monitoring plots (averaged across all plots) within a specific year, detection is the probability of a wētā being detected within a specific year given the plot is occupied, colonisation is the probability that an unoccupied plot in year $t$ becomes occupied in year $t+1$, and extinction is the probability an occupied plot in year $t$ becomes unoccupied in year $t+1$ (MacKenzie et al., 2003; MacKenzie \& Nichols, 2004). Extinction can alternatively be assessed as persistence (Ф $=1-\varepsilon)$, which is the probability that an occupied plot in year $t$ remains occupied in year $t+1$ (MacKenzie et al., 2006). For the purposes of this study we focused on persistence.

There are three assumptions that must be upheld for occupancy models to be accurate. Firstly, populations are assumed to be closed to occupancy change during a particular season, meaning there should be no abandonment or colonization of monitoring plots during the fiveday survey period (MacKenzie et al., 2002; MacKenzie et al., 2006). Secondly, it is assumed that all individuals of the species of interest are correctly identified when detected (Mackenzie et al., 2002; MacKenzie et al., 2006). Finally, it is assumed that detection probabilities between monitoring plots are independent (MacKenzie et al., 2002; MacKenzie 
et al., 2006). All assumptions are assumed to be true for the MGW monitoring since repeat surveys within a season were completed in a short period of time (five-days) compared to the annual interval across which colonisation and extinction probabilities were calculated.

Occupancy, detection, colonisation, and persistence probabilities can also be modelled as a function of measured covariates (Mackenzie et al., 2002). This is important because it is unlikely that probabilities are constant across sites and surveys (MacKenzie et al., 2006). Covariates can be classified as site-specific, referring to covariates that are specific to each site and constant throughout a specific season or year (e.g. gorse type or plot topography) or survey-specific, referring to covariates that are variable throughout a specific season or year (e.g. observer or weather; MacKenzie et al., 2002; MacKenzie et al., 2006). Detection can be modelled as a function of both these covariate types, whereas occupancy, can only be modelled as a function of site-specific covariates due to the assumption that sites are closed and occupancy is constant during a season (MacKenzie et al., 2006). Colonisation and persistence are between year measures and therefore can be modelled as a function of year, linear trend (over survey periods), and site-specific covariates.

MGW population trajectory has previously been assessed by Darryl MacKenzie for years 2005 to 2012. In order to compare results from 2013 - 2018, we developed similar models to MacKenzie (2012). Seven models were developed to assess MGW population trajectory. Sitespecific covariates 'gorse type', 'gorse cover', and 'gorse height' were available for years 2005 and 2018 , but have not held constant over this time period as the model assumes. Therefore, it is unreasonable to include them as a function of occupancy in this multi-season analysis. 'Observer' (allowed to vary between seasons) and 'weather' covariates were included as a function of detection probability in all models as their effects were not of direct interest. The main covariates that concerned MGW population trajectory were year and linear trend. These two covariates were included in varying combinations across the seven models as a function of colonisation and/or persistence.

As each of the seven models provide a slightly different fit, Akaike's Information Criterion (AIC), a common model comparison criterion, was used to select the most parsimonious model (Burnham \& Anderson, 2002). In AIC theorem, if the sample size is considered small in proportion to the number of parameters ( $n / K<40$ ), it is suggested that corrected AIC (AICC) is 
used (Burnham \& Anderson, 2002). The sample size for our multi-season analysis was fairly small ( $n=100)$, and $n / K$ was less than 40 for all models, therefore, we chose to use AICc.

To assess the fit of models to the data, a parametric bootstrap test ( $n=1000$ permutations) was run on the global model(s) (models with most covariates; Burnham \& Anderson, 2002). The test assesses whether the observed Pearson chi-square statistic $\left(x^{2}\right)$ is unusually large by comparing the frequency of observed and expected frequency histories in the global model with bootstrapped data (MacKenzie \& Bailey, 2004). If the model is adequate, the overdispersion parameter ( $\hat{c})$ is approximately equal to one (MacKenzie \& Bailey, 2004).

For the two global models in our population trajectory analysis, $\hat{c}$ was not found to be significantly greater than one (Table 2.2 , model \#2 $p=0.23, \hat{c}=0$; model $\# 5 p=0.27, \hat{c}=0$ ) suggesting no evidence of overdispersion, but rather potential underdispersion. This can be due to overparamertsiation and it would usually be recommended to assess simpler models, however, even the null model (no covariates) had a c of zero. This may be a problem with the overall dataset and the low detection rates in the later years (2013-2018). Therefore, models were interpreted with caution.

In addition to population trajectory, we assessed the effect of site-specific covariates on MGW occupancy probability in years 2005 and 2018, using single-season, single-species models. Due to the large number of potential models that could be developed using all covariates, we took an a priori approach, similar to MacKenzie (2012), and developed models focused on determining the best fit for either occupancy or detection probabilities. For example, when assessing the effects of site covariates on occupancy probability in 2005 , survey-specific covariates 'observer' and 'weather' were always included as a function of detection probability. When assessing the same effects on occupancy probability in 2018, no covariates were modelled as a function of detection, due to the much lower naïve occupancy impairing the model's ability to incorporate seven or more parameters.

As with multi-season models, a parametric bootstrap test $(n=1000)$ was run to assess global model fit. For both the 2005 and 2018 occupancy and detection-focused global models, $\hat{c}$ was not significantly greater than one $(2005 \boldsymbol{\Psi} p=0.97, \hat{c}=0.45 ; 2005 \boldsymbol{P} p=0.99, \hat{c}=0.4 ; 2018 \boldsymbol{\Psi}$ $p=073, \hat{c}=0.29 ; 2018 \boldsymbol{P} p=0.99, \hat{c}=0)$. However, a $\hat{c}$ greatly less than one can suggest underdispersion, and 2018 detection models had a $\hat{c}$ of 0 . To account for this, we focused on 
simpler models with only additive effects and disregarded any results from models that were highly underdispersed $(\hat{c}=0)$.

AICc was used to select the most parsimonious models for both probabilities and years as sample sizes were small $(2005 n=75,2018 n=78)$. Models where $\Delta$ AICc was less than 4 , were considered to be supported by the data (Burnham \& Anderson, 2002). For each covariate in supported models, the relative variable importance (RVI) was estimated by summing model weights $\left(w_{i}\right)$ across all models in which the covariate was included (MacKenzie, 2012; Fischer, 2016). Covariates with low RVI were suggested to have little importance in predicting occupancy or detection probabilities, covariates with high RVI were suggested to be useful predictors, and covariates with average RVI ( 50\%) were suggested to be ambiguous in their ability to predict occupancy or detection probabilities (MacKenzie, 2012; Fischer, 2016).

\section{$2.4 \quad$ Results}

\subsubsection{Change in MGWSR gorse habitat}

The structure of the gorse mosaic within the MGWSR has changed substantially over the past 14 years (2005 - 2018; Fig. 2.2). The quantity of monitoring plots containing semi-browsed gorse has decreased significantly from $44 \%$ (2005) to $9 \%(2018 ; z=-3.088, p=0.002)$. Unbrowsed gorse bushes are now the dominant type of gorse bush found in the reserve (56\% $2005 ; 91 \%$ 2018). Browsed gorse bushes were uncommon in both years (4\% 2005; 0\% 2018) and are generally only found around the edges of tracks and clearings. The approximate height of gorse bushes also changed over time (Fig. 2.3), with the number of monitoring plots containing bushes above $2 \mathrm{~m}$ in height increasing 1.5-fold from 53\% in 2005 to $81 \%$ in 2018 $(z=-3.522, p<0.001)$.

Assessment of gorse cover within $3 \mathrm{~m}$ radius $\left(28 \mathrm{~m}^{2}\right)$ plots between 2005 and 2018 revealed some change (Fig. 2.4). The proportion of 2005 plots with low gorse cover $(0-49 \%)$ has increased from $37 \%$ of plots to $51 \%$ of plots in 2018 , and inversely the proportion of high cover plots (50 - 100\%) in 2005 has decreased from 63\% to $49 \%$ in 2018 . However, this result was not significant $(z=1.739, p=0.082)$. 
Despite the change in gorse structure since 2005, the number of plots within each of the timed search categories $(5,10,15$, and, 20 minutes) has not changed substantially over the past 14 years $(2014 z=-0.103, p=0.918 ; 2015 z=-1.109, p=0.234 ; 2016 z=-1.421, p=0.155 ; 2017$ $z=0.784, p=0.433 ; 2018 z=0.784, p=0.433)$, resulting in similar total potential search efforts in 2005 and 2014 - 2018 in relation the number of plots available (Fig. 2.5).

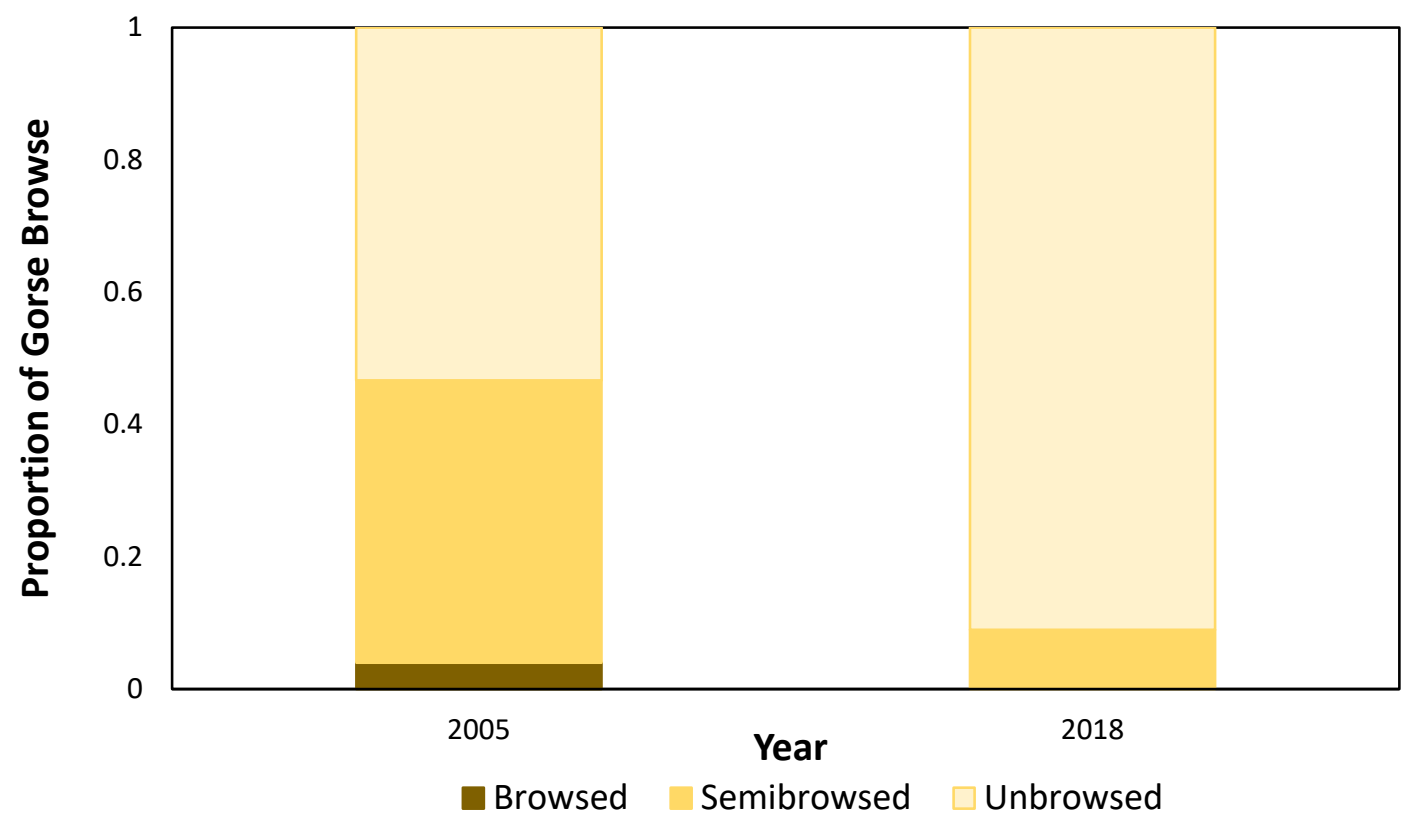

Figure 2.2 Change in monitoring plot gorse browse between 2005 and 2018 in the MGWSR. Data not available for years $2006-2017$.

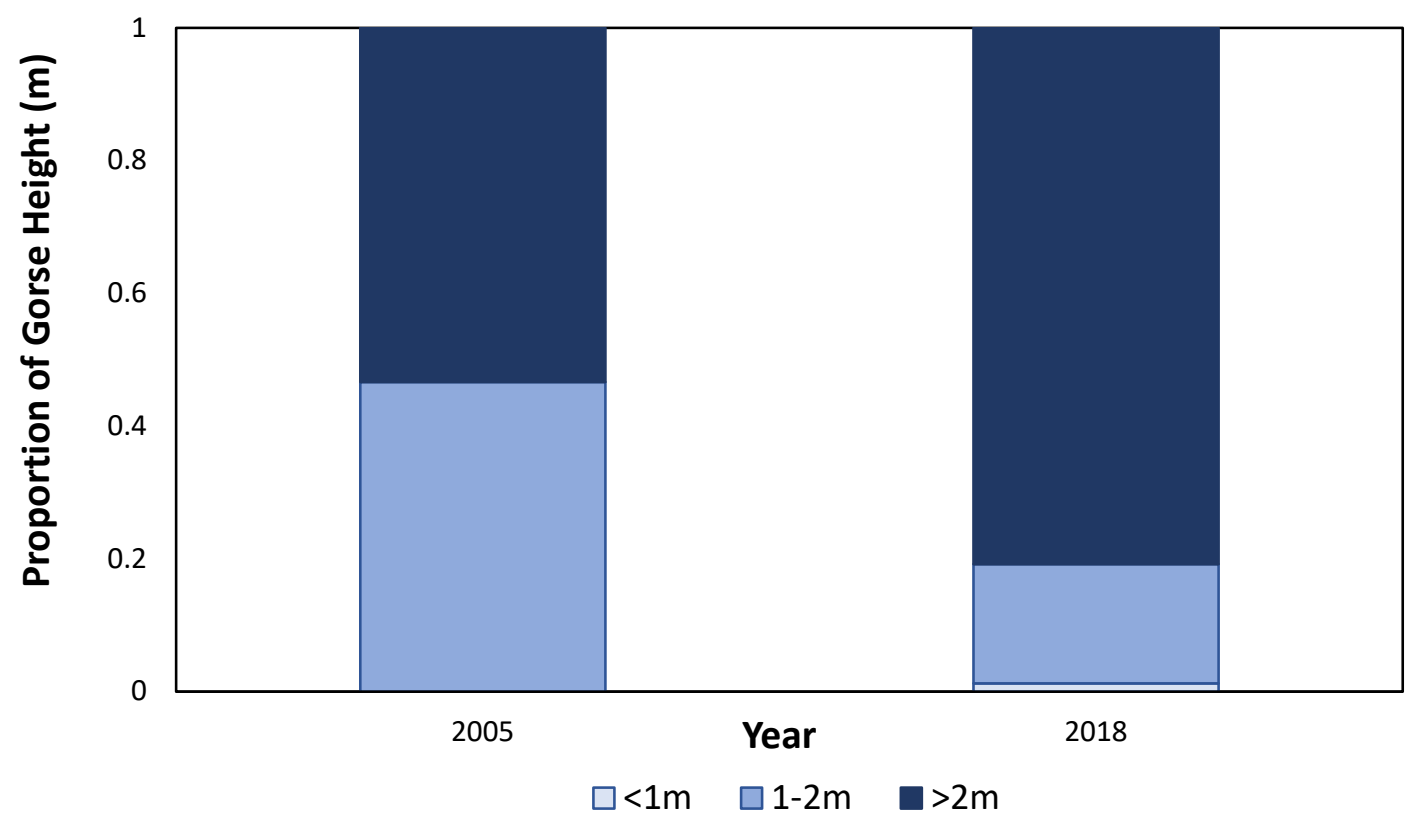

Figure 2.3 Change in monitoring plot gorse height between 2005 and 2018 in the MGWSR. Data not available for years $2006-2017$. 


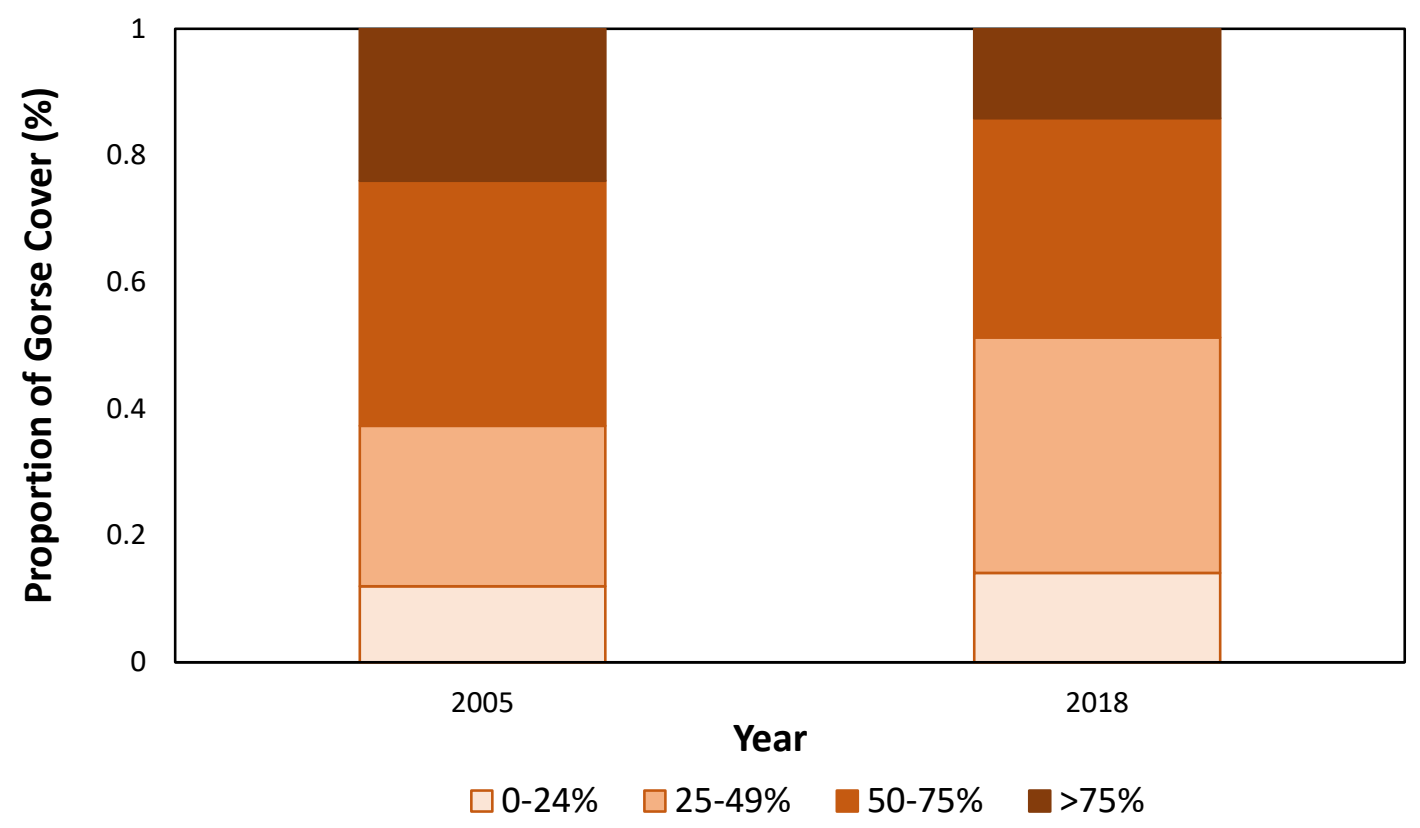

Figure 2.4 Change in monitoring plot gorse cover between 2005 and 2018 in the MGWSR. Data not available for years $2006-2017$.

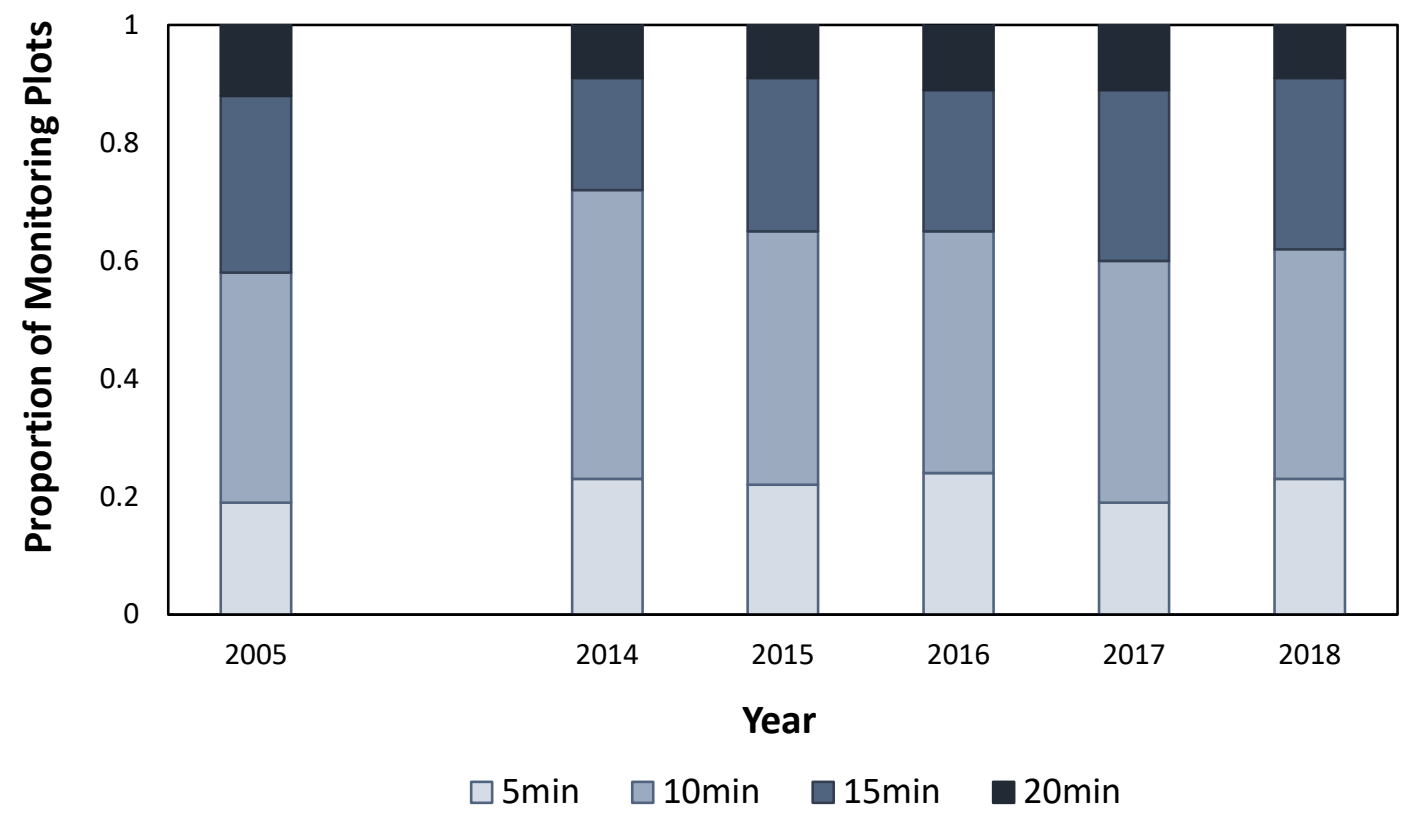

Figure 2.5 Proportion of annual monitoring plots in each search time category $(5,10,15$, and 20mis) for 2005 and 2014 - 2018. Data not available for year 2006 - 2013.

\subsubsection{Change in rate of wētā discovery}

The average time required to find a MGW during annual monitoring was found to have increased eight-fold since 2005 ( $z=5.484, p<0.001$; Fig. 2.6). Wētā were found at an average rate of one every 30mins in 2005 compared to one every four hours in 2018. Average time 
until a wētā was discovered in 2016 (1.7hrs/wētā) was also significantly less than in 2017 (5.3hrs/wētā; z=-3.283, p=0.013) and 2018 (4.1hrs/wētā; z=-3.232, p=0.015).

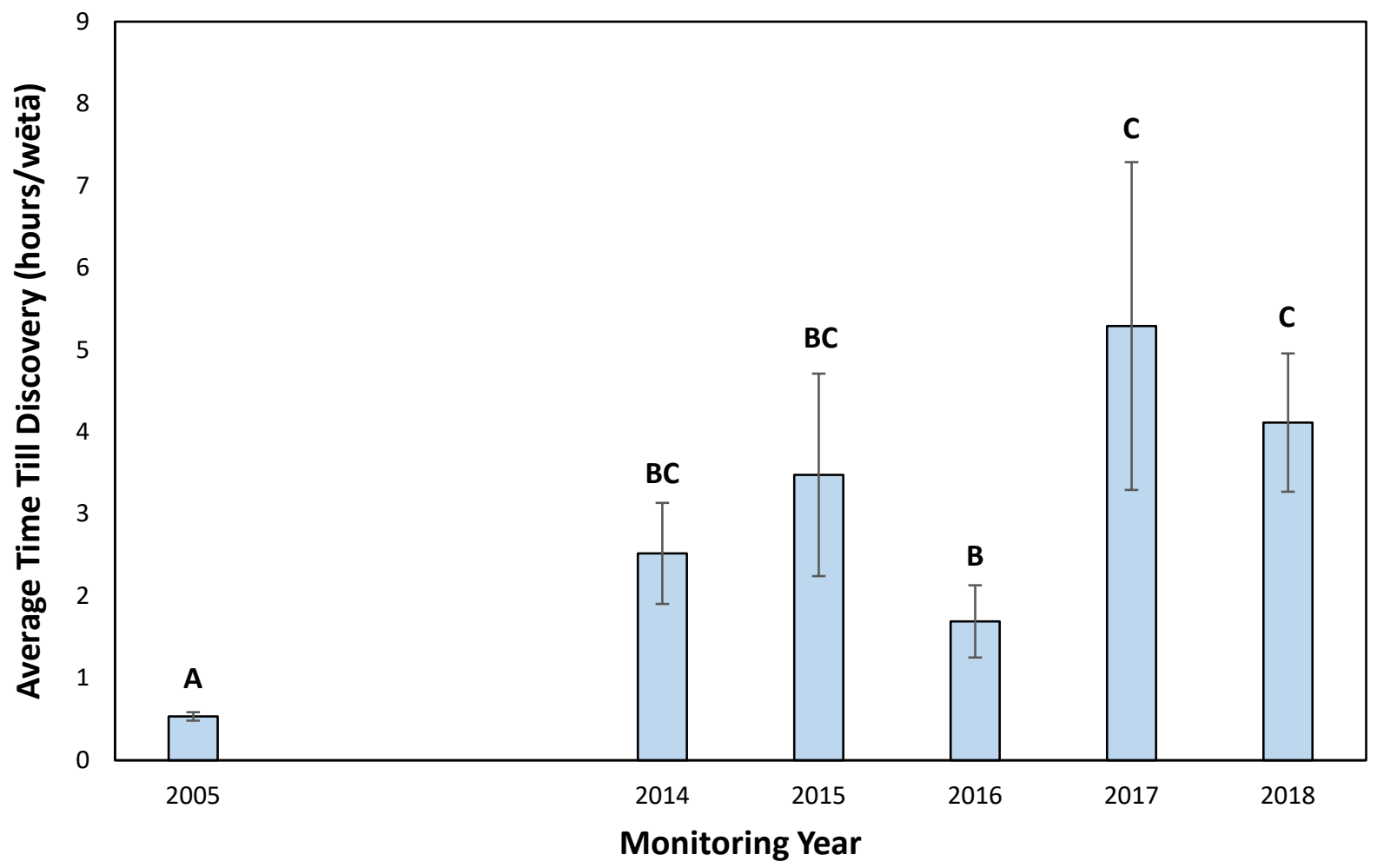

Figure 2.6 Average time till discovery (hours) per wētā over six monitoring years. Error bars are standard errors. Different letters indicate where significant differences exist between years. .

\subsubsection{MGW population trajectory}

Naïve occupancy probabilities (proportion of sites were MGW were detected in year $t$ ) were estimated for comparison with modelled occupancy estimates (Fig. 2.7). Naïve estimates suggest the MGW occupancy in the MGWSR has declined since 2011. Naïve occupancy in 2018 (17\%) has declined approximately three-fold since monitoring first began in 2005 (49\%; Appendix $2.6 \& 2.7)$.

The top model for population trajectory included 'year' as a function of colonisation (Table 2.2 ), suggesting the probability of plot colonisation varies between years. This was the only model considered to be supported by the data $(\triangle \mathrm{AIC}<4)$. From figure 2.9 , it appears the rate of colonisation has declined since 2005 , but should be interpreted with caution as large and sometimes negative standard errors are associated with these estimates. Persistence was 
best modelled as constant over time (Fig. 2.10). Overall, MGW occupancy shows a declining trend since 2012 (Fig. 2.8). Colonisation and persistence rates influence the final occupancy estimates in this model, therefore due to the large and negative standard errors for colonisation estimates, in addition to all models (including the one with no covariates) having a c value of 0 , the decline in MGW modelled occupancy should be accepted with caution.

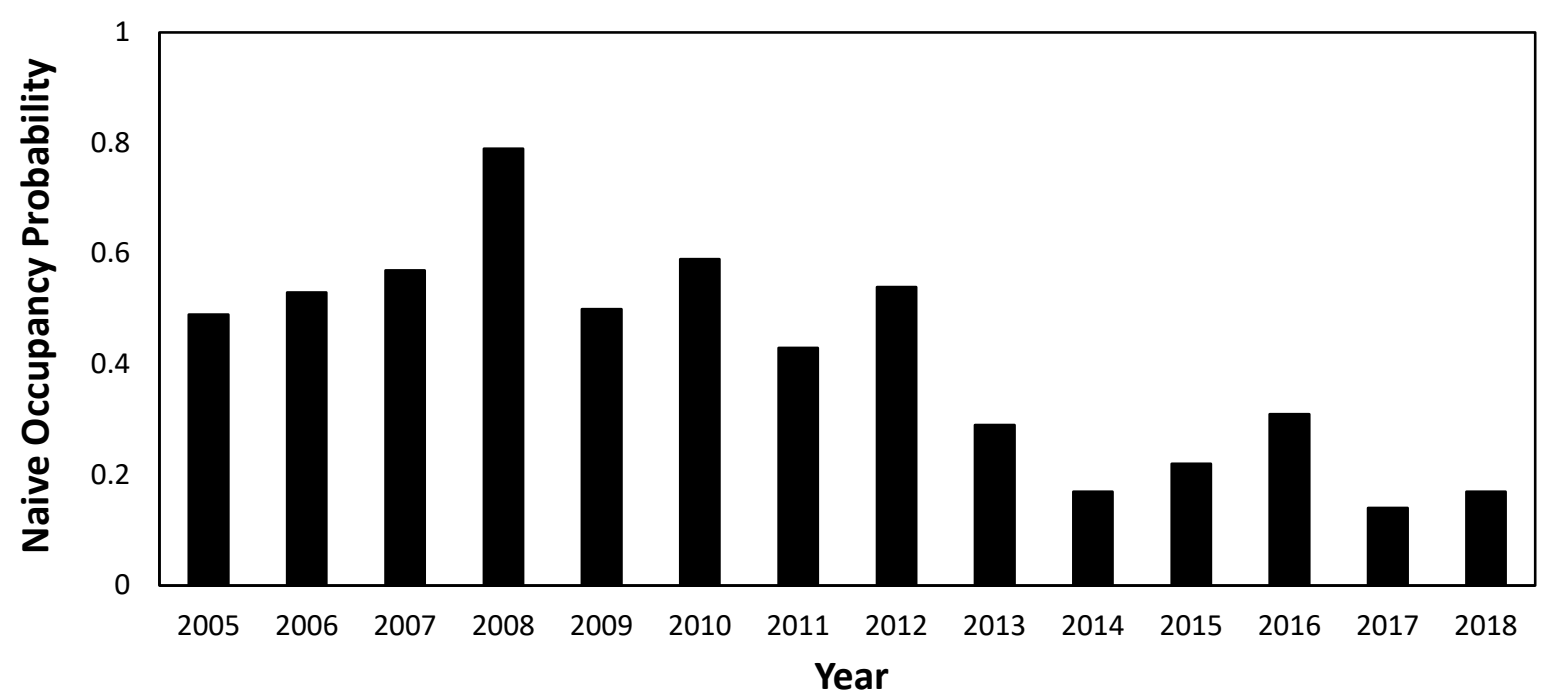

Figure 2.7 Naïve occupancy (proportion of sites where MGW where detected) for years 2005 - 2018.

Table 2.2 Summary of multi-season model selection for MGW population trajectory between 2005 and 2018. Detection $(\boldsymbol{p})$ covariates year, observer and weather were included in all models, occupancy $(\boldsymbol{\Psi})$ is held constant ('.') for all models, and covariates year and trend were allowed to vary for colonisation $(\mathbf{Y})$ and persistence $(\boldsymbol{\phi})$. For each model the corrected Akaike Information Criteria (AICC), the relative difference of AICC in relation to the top model ( $\triangle A I C C)$, Akaike weight $\left(w_{i}\right)$, and number of parameters $(K)$ is given. Shaded models with $\triangle \mathrm{AICC}<4$ are considered supported by the data.

\begin{tabular}{|c|c|c|c|c|c|}
\hline Model & & AICC & $\triangle \mathrm{AICC}$ & $w_{i}$ & $\mathrm{~K}$ \\
\hline $\boldsymbol{\Psi}(),. \boldsymbol{Y}($ Year), $\boldsymbol{\phi}()$, & $\boldsymbol{p}$ (Year * Observer + Weather) & 3106.75 & 0 & 0.9716 & 102 \\
\hline $\boldsymbol{\Psi}(),. \boldsymbol{Y}($ Year), $\boldsymbol{\phi}($ Year) & $\boldsymbol{p}$ (Year * Observer + Weather) & 3113.83 & 7.08 & 0.0282 & 114 \\
\hline $\boldsymbol{\Psi}(),. \boldsymbol{Y}(),. \quad \boldsymbol{\phi}($ Year $)$ & $\boldsymbol{p}$ (Year * Observer + Weather) & 3124.56 & 17.81 & 0.0001 & 102 \\
\hline $\boldsymbol{\Psi}(),. \boldsymbol{Y}(),. \quad \boldsymbol{\phi}($ Trend), & $\boldsymbol{p}$ (Year * Observer + Weather) & 3129.32 & 22.57 & 0 & 91 \\
\hline $\boldsymbol{\Psi}(),. \mathbf{Y}$ (Trend), $\boldsymbol{\phi}$ (Trend), & $\boldsymbol{p}$ (Year * Observer + Weather) & 3130.46 & 23.71 & 0 & 92 \\
\hline $\boldsymbol{\Psi}(),. \mathbf{Y}(),. \quad \boldsymbol{\phi}()$. & $\boldsymbol{p}$ (Year * Observer + Weather) & 3131.01 & 24.26 & 0 & 90 \\
\hline $\boldsymbol{\Psi}(),. \boldsymbol{Y}($ Trend), $\boldsymbol{\phi}()$, & $\boldsymbol{p}$ (Year * Observer + Weather) & 3131.13 & 24.38 & 0 & 91 \\
\hline
\end{tabular}




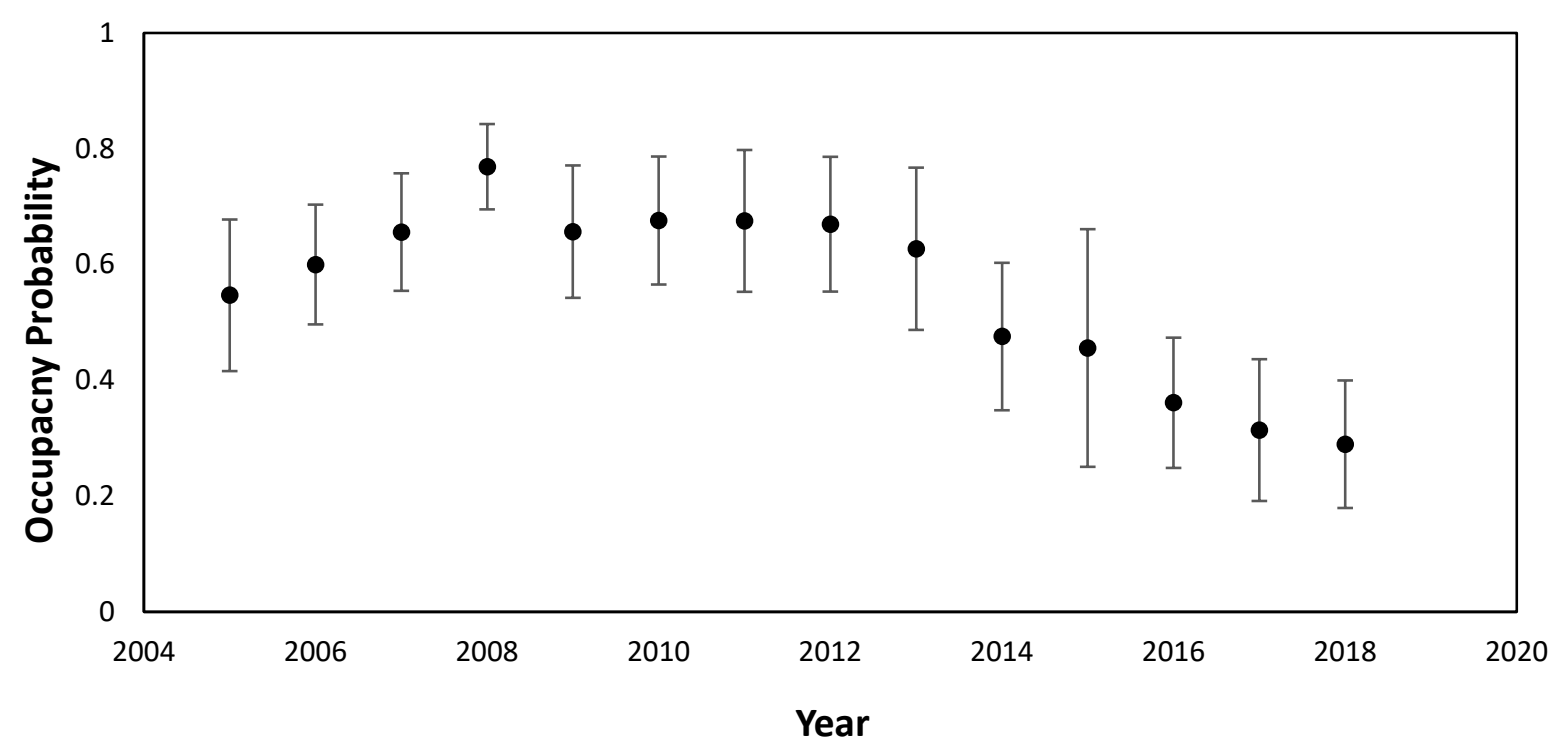

Figure 2.8 Estimated occupancy probability $(\boldsymbol{\Psi})$ of MGW in the MGWSR for years 2005-2018. Estimates were sourced from the top ranked multi-season model in table 2.2. Error bars represent $95 \%$ confidence intervals.

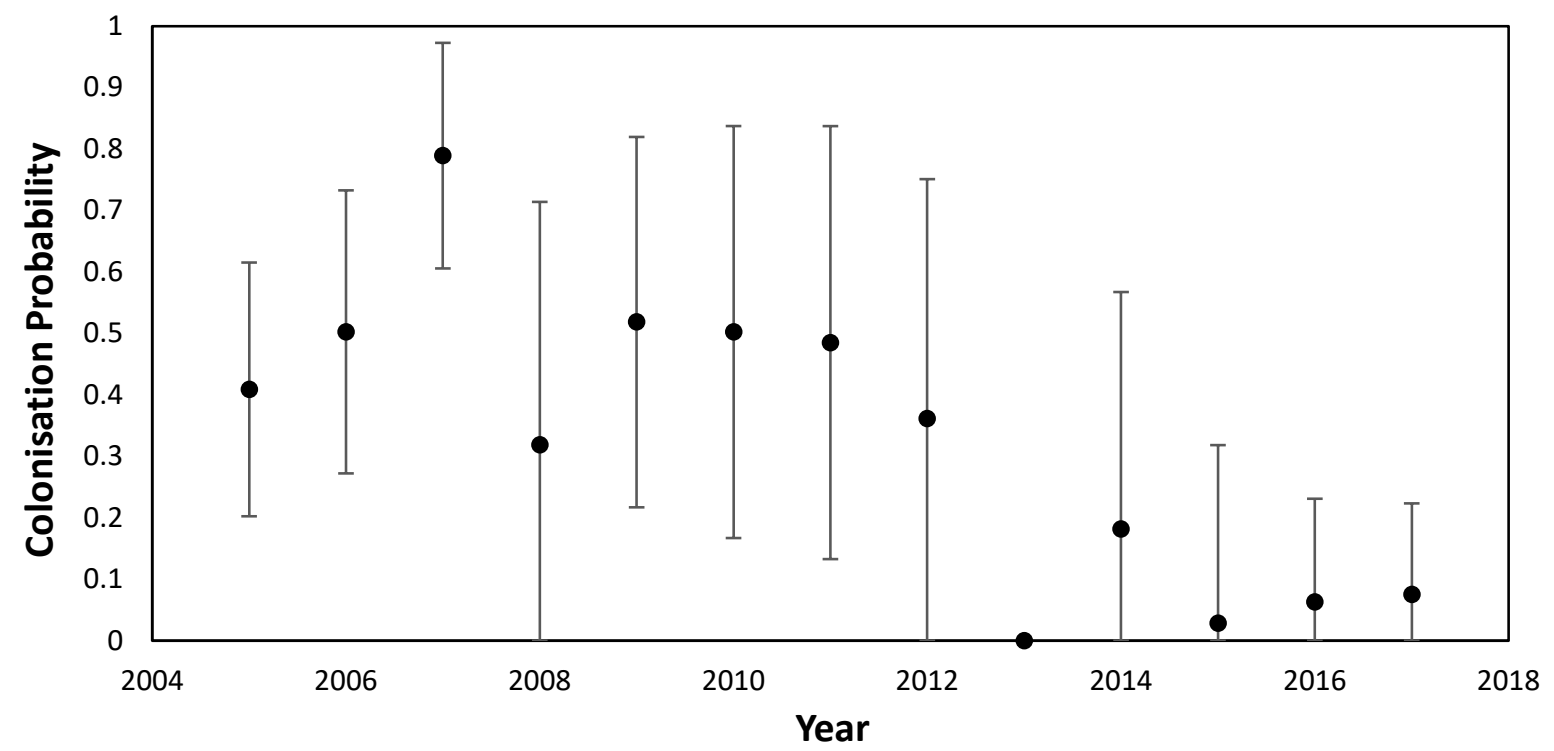

Figure 2.9 Estimated colonisation probability $(Y)$ of MGW in the MGWSR between years 20052018. Colonisation is a between year measure and probabilities between years $t$ and $t+1$ are presented at year $t$ (beginning of period). Estimates were sourced from the top ranked multiseason model in table 2.2. Error bars represent $95 \%$ confidence intervals. 


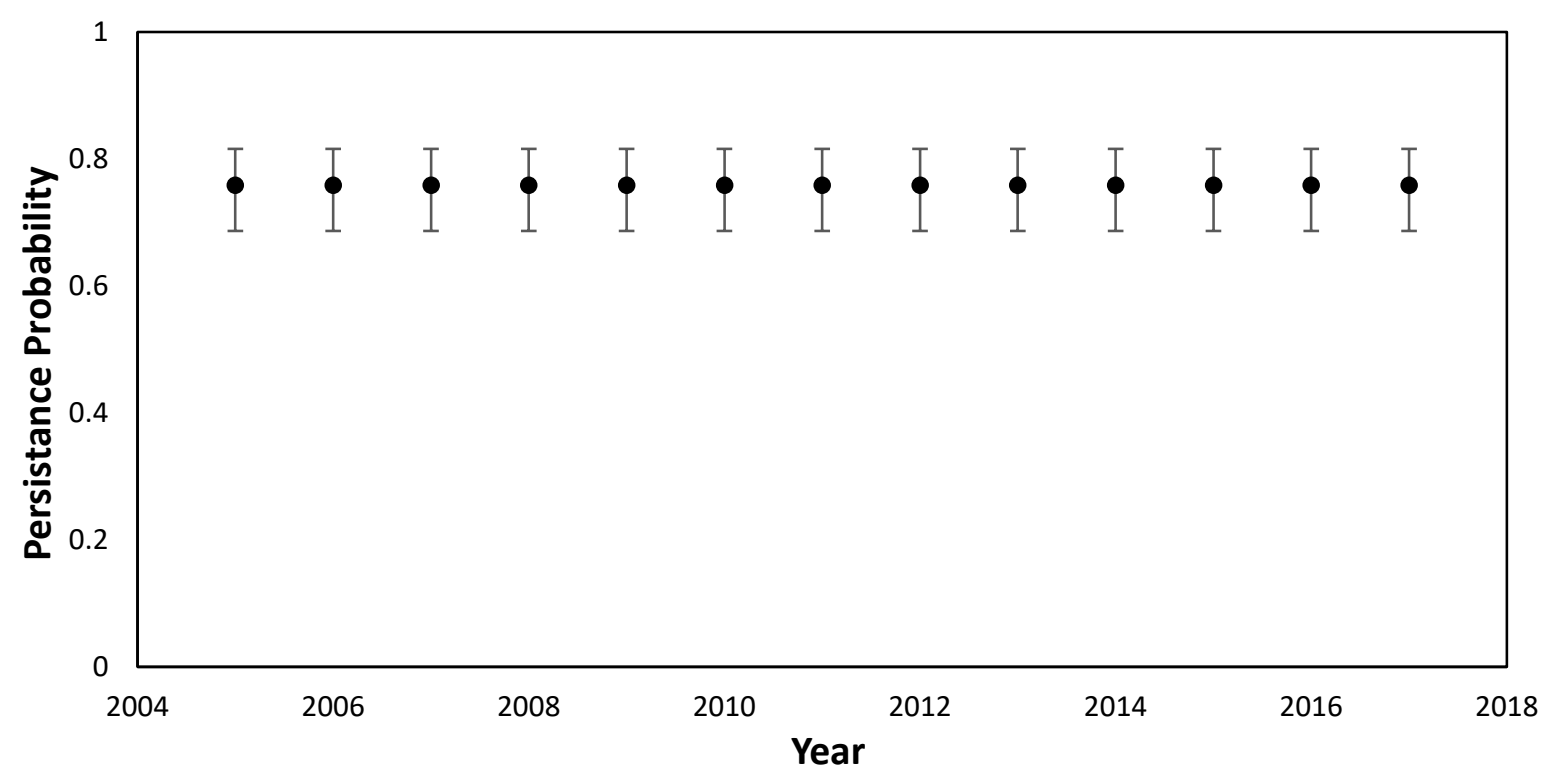

Figure 2.10 Estimated persistence probability $(\phi)$ of MGW in the MGWSR between years 2005-2018. Persistence is a between year measure and probabilities between years $t$ and $t+1$ are presented at year $t$ (beginning of period). Estimates were sourced from the top ranked multi-season model in table 2.2 , which did not allow persistence to vary with any covariate. Error bars represent $95 \%$ confidence intervals.

\subsubsection{Abiotic effects on MGW occupancy and detection}

Occupancy and detection in 2005 were modelled separately as a function of site and surveyspecific covariates. The top model for occupancy probability featured no site-specific covariates and occupancy was held constant (Table 2.3). This model suggests MGW occupancy was not influenced by any site-specific covariates and estimated MGW occupancy in the MGWSR to be $0.54( \pm 0.06)$ for the year 2005. A further seven models were considered to be supported by the data $(\triangle \mathrm{AIC}<4)$. The covariate 'browse' estimated occupancy to be highest in semi-browsed plots $(0.62 \pm 0.09)$ when the plot was on/in a ridge or gully $(0.67$ \pm 0.11 ), in interior gorse habitat $(0.64 \pm 0.10)$, or the gorse was additionally over $2 \mathrm{~m}$ height (0.65 \pm 0.12$)$. The covariates 'topography', 'location', and 'height' estimated occupancy to be highest when the plot was on/in a ridge or gully $(0.6 \pm 0.1)$, in interior gorse habitat $(0.55$ \pm 0.09 ), or when the gorse was between $1-2 \mathrm{~m}(0.57 \pm 0.1)$. However, all covariates ('browse', 'topography', 'height', and 'location') had RVI's of $28 \%, 15 \%, 12 \%$, and $12 \%$, respectively, suggesting they were not useful predictors of MGW occupancy in 2005. 
Assessment of MGW detection probability in 2005 revealed no survey-specific covariates in the top model (Table 2.4). This model suggests MGW detection was not influenced by observer, weather, or day effects and estimated MGW detection in the MGWSR to be 0.52 $( \pm 0.05)$. Two other models were considered to be supported by the data $(\triangle A I C<4)$. The covariate 'observer', in the second ranked model, estimated detection probability varied slightly with observer. Observer 1 had the highest detection rate $(0.58 \pm 0.08)$, followed by observer $3(0.56 \pm 0.08)$ and observer $2(0.42 \pm 0.08)$. The covariate 'weather', in the third ranked model, estimated detection probabilities to be highest in overcast conditions $(0.55$ $\pm 0.07)$, followed by rainy conditions $(0.5 \pm 0.13)$ and fine conditions $(0.49 \pm 0.08)$. However, the RVI's for 'observer' and 'weather' were only $26 \%$ and $10 \%$, respectively, suggesting these are not useful covariates for predicting detection probability.

Occupancy and detection were also modelled individually for 2018. The top model for occupancy probability in 2018 featured the covariates 'location', 'cover', and 'topography' (Table 2.5). This model suggests that when there is a higher percentage of gorse cover $(>50 \%)$, the plot is in edge habitat, and on/in a ridge or gully, there is higher occupancy by MGW (0.97 $\pm 0.05)$. In contrast, when gorse cover is less than $50 \%$, the plot is located in interior habitat, and on a face, occupancy is estimated to extremely low (0.04 \pm 0.04$)$. The average occupancy of MGW in 2018 is estimated to be $0.27( \pm 0.12)$. This is a two-fold decline in estimated occupancy compared to 2005 and is consistent with naïve and multi-season model estimates (Fig. 2.7 and 2.8). Seven other models, all containing the covariate 'location', were considered to be supported by the data (Table 2.5). In all models, edge habitat had the highest probability of occupancy $(0.86 \pm 0.29)$, but high gorse cover, bushes less than $2 \mathrm{~m}$ tall, and plots located on/in rides and gullies were also estimated as favourable characteristics. The RVI for 'location' was $99 \%$ suggesting this covariate is a useful for predicting the occupancy of MGW in the MGWSR in 2018. All other covariates ('cover', topography', and 'height') in supported models had low RVI's suggesting they were not useful for predicting wētā occupancy.

The top model for detection probability in 2018 did not include any survey-specific covariates (Table 2.6). The model suggests MGW detection was not influenced by observer, weather, or day and estimated the MGW detection probability in the MGWSR to be $0.18( \pm 0.06)$. Three other models including a single covariate were supported by the data (Table 2.6). Of these models, only the model containing 'weather' produced a $\hat{c}$ above 0 , suggesting the other 
models were overparamertised. This is likely true due to the low naïve estimate for year (0.17). Henceforth, these models were excluded from interpretation. 'Weather' estimated detection probability to be highest in rainy conditions $(0.45 \pm 0.23)$, however, had a low RVI of $20 \%$, suggesting it is not a useful covariate.

Table 2.3 Summary of 2005 single-season model selection for MGW occupancy. Detection $(\boldsymbol{p})$ covariates observer and weather were included in all models while site-covariates browse, Topography, height and cover were allowed to vary for occupancy $(\boldsymbol{\Psi})$. For each model the corrected Akaike Information Criteria (AICC), the relative difference of AICc in relation to the top model $(\triangle \mathrm{AICC})$, Akaike weight $\left(w_{i}\right)$, and number of parameters $(\mathrm{K})$ is given. Shaded models with $\triangle \mathrm{AICC}<4$ are considered supported by the data.

\begin{tabular}{|c|c|c|c|c|c|}
\hline Model & & AICc & $\triangle \mathrm{AICC}$ & $w_{i}$ & $\kappa$ \\
\hline $\boldsymbol{\Psi}()$. & $\boldsymbol{p}$ (Obs + Weather) & 285.68 & 0 & 0.2455 & 6 \\
\hline $\boldsymbol{\Psi}$ (Browse), & $\boldsymbol{p}$ (Obs + Weather) & 286.83 & 1.15 & 0.1381 & 7 \\
\hline $\boldsymbol{\Psi}$ (Topography), & $\boldsymbol{p}$ (Obs + Weather) & 287.54 & 1.86 & 0.0968 & 7 \\
\hline $\boldsymbol{\Psi}$ (Height) & $\boldsymbol{p}$ (Obs + Weather) & 287.97 & 2.29 & 0.0781 & 7 \\
\hline $\boldsymbol{\Psi}$ (Location), & $\boldsymbol{p}$ (Obs + Weather) & 288.07 & 2.39 & 0.0743 & 7 \\
\hline $\boldsymbol{\Psi}$ (Browse + Topography), & $\boldsymbol{p}$ (Obs + Weather) & 288.75 & 3.07 & 0.0529 & 8 \\
\hline $\boldsymbol{\Psi}$ (Browse + Location), & $\boldsymbol{p}$ (Obs + Weather) & 289.14 & 3.46 & 0.0435 & 8 \\
\hline $\boldsymbol{\Psi}$ (Browse + Height) & $\boldsymbol{p}$ (Obs + Weather) & 289.25 & 3.57 & 0.0412 & 8 \\
\hline $\boldsymbol{\Psi}$ (Topography + Height), & $\boldsymbol{p}$ (Obs + Weather) & 289.99 & 4.31 & 0.0284 & 8 \\
\hline $\boldsymbol{\Psi}$ (Topography + Location), & $\boldsymbol{p}$ (Obs + Weather) & 290.01 & 4.33 & 0.0282 & 8 \\
\hline $\boldsymbol{\Psi}$ (Cover) & $\boldsymbol{p}$ (Obs + Weather) & 290.12 & 4.44 & 0.0267 & 8 \\
\hline $\boldsymbol{\Psi}$ (Height + Location) & $\boldsymbol{p}$ (Obs + Weather) & 290.41 & 4.73 & 0.0231 & 8 \\
\hline $\boldsymbol{\Psi}$ (Browse + Topography + Height), & $\boldsymbol{p}$ (Obs + Weather) & 291.1 & 5.42 & 0.0163 & 9 \\
\hline $\boldsymbol{\Psi}$ (Browse + Topography + Location), & $\boldsymbol{p}$ (Obs + Weather) & 291.17 & 5.49 & 0.0158 & 9 \\
\hline $\boldsymbol{\Psi}$ (Browse + Cover) & $\boldsymbol{p}$ (Obs + Weather) & 291.36 & 5.68 & 0.0143 & 9 \\
\hline $\boldsymbol{\Psi}$ (Browse + Height + Location), & $\boldsymbol{p}$ (Obs + Weather) & 291.65 & 5.97 & 0.0124 & 9 \\
\hline $\boldsymbol{\Psi}$ (Topography + Cover) & $\boldsymbol{p}$ (Obs + Weather) & 291.76 & 6.08 & 0.0117 & 9 \\
\hline $\boldsymbol{\Psi}$ (Topography + Height + Location), & $\boldsymbol{p}$ (Obs + Weather) & 292.53 & 6.85 & 0.008 & 9 \\
\hline $\boldsymbol{\Psi}$ (Height + Cover) & $\boldsymbol{p}$ (Obs + Weather) & 292.55 & 6.87 & 0.0079 & 9 \\
\hline $\boldsymbol{\Psi}$ (Cover + Location) & $\boldsymbol{p}$ (Obs + Weather) & 292.71 & 7.03 & 0.0073 & 9 \\
\hline $\boldsymbol{\Psi}$ (Browse + Topography + Cover) & $\boldsymbol{p}$ (Obs + Weather) & 293.01 & 7.33 & 0.0063 & 10 \\
\hline $\boldsymbol{\Psi}$ (Browse + Topography + Height + Location), & $\boldsymbol{p}$ (Obs + Weather) & 293.61 & 7.93 & 0.0047 & 10 \\
\hline $\boldsymbol{\Psi}$ (Browse + Height + Cover) & $\boldsymbol{p}$ (Obs + Weather) & 293.95 & 8.27 & 0.0039 & 10 \\
\hline $\boldsymbol{\Psi}$ (Browse + Location + Cover) & $\boldsymbol{p}$ (Obs + Weather) & 293.96 & 8.28 & 0.0039 & 10 \\
\hline $\boldsymbol{\Psi}$ (Topography + Height + Cover) & $\boldsymbol{p}$ (Obs + Weather) & 294.36 & 8.68 & 0.0032 & 10 \\
\hline $\boldsymbol{\Psi}$ (Topography + Cover + Location), & $\boldsymbol{p}$ (Obs + Weather) & 294.43 & 8.75 & 0.0031 & 10 \\
\hline $\boldsymbol{\Psi}$ (Cover + Height + Location) & $\boldsymbol{p}$ (Obs + Weather) & 295.21 & 9.53 & 0.0021 & 10 \\
\hline $\boldsymbol{\Psi}$ (Browse + Topography + Height + Cover) & $\boldsymbol{p}$ (Obs + Weather) & 295.48 & 9.8 & 0.0018 & 11 \\
\hline $\boldsymbol{\Psi}$ (Browse + Topography + Height + Cover + Location), & $\boldsymbol{p}$ (Obs + Weather) & 298.3 & 12.62 & 0.0004 & 12 \\
\hline
\end{tabular}


Table 2.4 Summary of 2005 single-season model selection for MGW detection. Occupancy $(\Psi)$ covariates browse, topography, height, cover, and location were included in all models while survey-covariates day, observer and weather were allowed to vary for detection $(\boldsymbol{p})$. For each model the corrected Akaike Information Criteria (AICc), the relative difference of AICc in relation to the top model $(\triangle \mathrm{AICc})$, Akaike weight $\left(w_{i}\right)$, and number of parameters $(\mathrm{K})$ is given. Shaded models with $\triangle \mathrm{AICC}<4$ are considered supported by the data.

\begin{tabular}{lllccc}
\hline Model & & AICc & \multicolumn{1}{c}{ AICc } & $\boldsymbol{w}_{\boldsymbol{i}}$ & $\mathbf{K}$ \\
\hline $\boldsymbol{\Psi}$ (Browse + Topography + Height + Cover + Location), & $\boldsymbol{p}()$. & 288.41 & 0 & 0.5462 & 8 \\
$\boldsymbol{\Psi}$ (Browse + Topography + Height + Cover + Location), & $\boldsymbol{p}$ (Observer) & 289.88 & 1.47 & 0.2619 & 10 \\
$\boldsymbol{\Psi}$ (Browse + Topography + Height + Cover + Location), & $\boldsymbol{p}$ (Weather) & 291.97 & 3.56 & 0.0921 & 10 \\
$\boldsymbol{\Psi}$ (Browse + Topography + Height + Cover + Location), & $\boldsymbol{p}$ (Observer + Weather) & 293.52 & 5.11 & 0.0424 & 12 \\
$\boldsymbol{\Psi}$ (Browse + Topography + Height + Cover + Location), & $\boldsymbol{p}$ (Day) & 294.2 & 5.79 & 0.0302 & 12 \\
$\boldsymbol{\Psi}$ (Browse + Topography + Height + Cover + Location), & $\boldsymbol{p}$ (Day + Observer) & 295.75 & 7.34 & 0.0139 & 14 \\
$\boldsymbol{\Psi}$ (Browse + Topography + Height + Cover + Location), & $\boldsymbol{p}$ (Day + Weather) & 296.43 & 8.02 & 0.0099 & 14 \\
\hline
\end{tabular}

Table 2.5 Summary of 2018 single-season model selection for MGW occupancy. Detection ( $\boldsymbol{p}$ ) covariates observer and weather were included in all models while site-covariates browse, Topography, height and cover were allowed to vary for occupancy $(\boldsymbol{\Psi})$. For each model the corrected Akaike Information Criteria (AICC), the relative difference of AICc in relation to the top model $(\triangle \mathrm{AICC})$, Akaike weight $\left(w_{i}\right)$, and number of parameters $(K)$ is given. Shaded models with $\triangle \mathrm{AICC}<4$ are considered supported by the data.

\begin{tabular}{lccccc}
\hline Model & & AICc & $\Delta$ AICc & $\boldsymbol{w}_{i}$ & K \\
\hline $\boldsymbol{\Psi}$ (Location + Cover + Topography), & $\boldsymbol{p}()$. & 143.41 & 0 & 0.2322 & 5 \\
$\boldsymbol{\Psi}$ (Location + Cover), & $\boldsymbol{p}()$. & 143.83 & 0.42 & 0.1882 & 4 \\
$\boldsymbol{\Psi}$ (Location), & $\boldsymbol{p}()$. & 144.15 & 0.74 & 0.1604 & 3 \\
$\boldsymbol{\Psi}$ (Location + Topography), & $\boldsymbol{p}()$. & 144.38 & 0.97 & 0.143 & 4 \\
$\boldsymbol{\Psi}$ (Location + Cover + Height + Topography), & $\boldsymbol{p}()$. & 145.73 & 2.32 & 0.0728 & 6 \\
$\boldsymbol{\Psi}$ (Location + Height), & $\boldsymbol{p}()$. & 145.8 & 2.39 & 0.0703 & 4 \\
$\boldsymbol{\Psi}$ (Location + Cover + Height), & $\boldsymbol{p}()$. & 145.9 & 2.49 & 0.0669 & 5 \\
$\boldsymbol{\Psi}$ (Location + Height + Topography), & $\boldsymbol{p}()$. & 146.31 & 2.9 & 0.0545 & 5 \\
\hline
\end{tabular}


Table 2.6 Summary of 2018 single-season model selection for MGW detection. Occupancy $(\boldsymbol{\Psi})$ covariates browse, Topography, height and cover were included in all models while survey-covariates day, observer and weather were allowed to vary for detection $(\boldsymbol{p})$. For each model the corrected Akaike Information Criteria (AICC), the relative difference of AICC in relation to the top model $(\triangle \mathrm{AICC})$, Akaike weight $\left(w_{i}\right)$, and number of parameters $(\mathrm{K})$ is given. Shaded models with $\triangle \mathrm{AICc}<4$ are considered supported by the data.

\begin{tabular}{llcccc}
\hline Model & & AICc & $\Delta$ AICc & $\boldsymbol{w}_{\boldsymbol{i}}$ & $\boldsymbol{K}$ \\
\hline $\boldsymbol{\Psi}()$, & $\boldsymbol{p}()$. & 153.04 & 0 & 0.5038 & 2 \\
$\boldsymbol{\Psi}()$, & $\boldsymbol{p}$ (Weather) & 154.88 & 1.84 & 0.2008 & 4 \\
$\boldsymbol{\Psi}()$, & $\boldsymbol{p}$ (Day) & 155.88 & 2.84 & 0.1218 & 6 \\
$\boldsymbol{\Psi}()$, & $\boldsymbol{p}$ (Observer) & 156.47 & 3.43 & 0.0907 & 7 \\
$\boldsymbol{\Psi}()$, & $\boldsymbol{p}$ (Day + Observer) & 158.43 & 5.39 & 0.034 & 11 \\
$\boldsymbol{\Psi}()$, & $\boldsymbol{p}$ (Day + Weather) & 158.61 & 5.57 & 0.0311 & 8 \\
$\boldsymbol{\Psi}()$, & $\boldsymbol{p}$ (Observer + Weather) & 160.15 & 7.11 & 0.0144 & 9 \\
$\boldsymbol{\Psi}()$, & $\boldsymbol{p}$ (Day + Observer + Weather) & 163 & 9.96 & 0.0035 & 13 \\
\hline
\end{tabular}

\subsubsection{Mammal monitoring}

Tracking indices suggest rat and mice populations are present within the reserve year-round and appear to peak during summer and autumn (Fig. 2.11). Possum interference shows a similar summer/autumn peaking trend, whereas, hedgehogs were regularly detected at low levels outside of hibernation months (typically June to September, depending on climate). There were no clear differences in detection between gorse and native habitats for all four species. The possum control operation conducted between February and April 2015 led to average post-control possum interference levels two-fold higher than pre-control levels ( $4 \%$ up to $\sim 8 \%)$. 


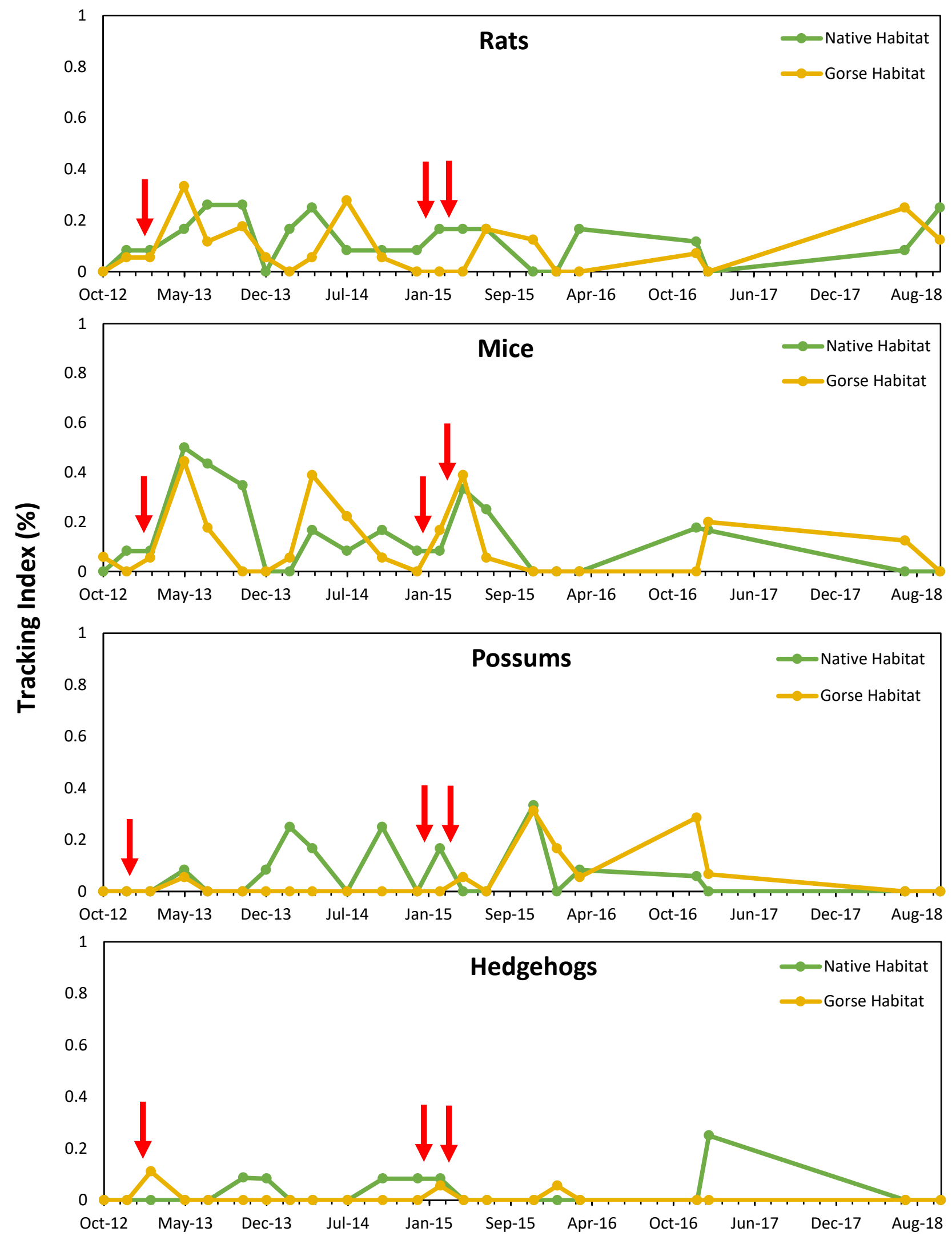

Figure 2.11 Tracking index (\%) for rats, mice, possums, and hedgehogs in the MGWSR from October 2012 to October 2018. Indices are categorised by gorse (gold) and native (green) habitats. Red arrows indicate the start of possum control operations within the reserve. 


\subsection{Discussion}

\subsubsection{State of the MGWSR}

Monitoring habitat change is important for informing management initiatives in conservation as changes may have negative or positive effects for the species of interest. In the MGWSR, we found a significant change in gorse structure and gorse height over 14-years, whereby the majority of gorse in the reserve is now unbrowsed and over $2 \mathrm{~m}$ in height. In contrast, the amount of gorse cover within the $3 \mathrm{~m}$ monitoring plots remained largely unchanged.

Unbrowsed gorse is generally less dense than gorse that has been browsed and may negatively affect the survival of MGW by exposing them to higher rates of predation. The open and branching structure of unbrowsed gorse as it ages ("old man" gorse) may no longer provide protection from climbing mammalian predators (Watts \& Thornburrow, 2009; C Watts pers. comm., 2018). In addition, unbrowsed tall bushes provide the perfect nursery for native saplings and ferns to thrive beneath them (Wotton \& McAlpine, 2013). The southernmost valley of the MGWSR is already dominated by native trees and ferns, and tree ferns and ground ferns are becoming noticeably more abundant throughout the two remaining gorse dominated valleys (Quinnell, 2015; DOC, 2016). The state of the gorse in these two valleys is likely promoting the growth of native species that will eventually shade the gorse out (Wotton \& McAlpine, 2013), resulting in loss of protective refuge sites for MGW in the presence of mammalian predators.

\subsubsection{Status of the giant wētā population at Mahoenui}

Invertebrate populations are not often monitored over the long-term and local extinction rates are largely unknown (Thomas et al., 2004; Chiari et al., 2013). Site-occupancy monitoring provides a practical method for monitoring cryptic or rare species when detection rates are substantially less than one (MacKenzie et al., 2002). For the MGW population in the MGWSR, we found a pronounced decline in occupancy since 2012. Persistence rates of MGW in monitoring plots from one year to another were relatively stable at around 0.75 , but the probability of colonisation between years appeared to decline over time, in particular, falling below 0.25 per annum over the past five years. Although occupancy estimates are not robust 
due to large standard errors in colonisation, they rely a similar picture to naïve occupancy estimates of an approximately three-fold decline since 2005 (Appendix 2.6 \& 2.7).

In addition to the trend found from occupancy estimates, we found that average time to discovery has increased from approximately 0.5 hours per wētā found in 2005 to 4.1 hours per wētā in 2018. Average time until a wētā was discovered provides a proxy for wētā abundance (S Hartley, pers. comm., 2019) and therefore suggests an eight-fold decline in relative abundance. These results suggest MGW are not as abundant and readily found as they were 14-years ago, and that the population is in a state of decline.

The cause of decline remains unknown but could be attributed to several factors. Firstly, the lack of regular pest control in the MGWSR resulting in an abundance of mammalian predators may be having a larger impact on the MGW population than originally though. The spikey, dense foliage of gorse is thought to provide protection to the wētā allowing them to have survived in the presence of mammalian predators for almost six decades (Richards, 1994; Watts \& Thornburrow, 2009). However, the quality of the gorse appears to have changed over this time becoming thinner and open, potentially exposing wētā to predation by climbing mammals (Watts \& Thornburrow, 2009; C Watts, pers. comm., 2018). In this study, we found unbrowsed gorse bushes are now the dominant type found in the MGWSR compared to 2005 (section 2.4.1). MGW may potentially be exposed to predation when on the ground ovipositing (females), mating, or moving between bushes.

Secondly, natural succession of the gorse is resulting in the reversion of the reserve to native vegetation. While gorse is still prevalent in the northernmost and middle valleys of the MGWSR, tree ferns, ground ferns, divaricating Coprosma spp., and mahoe are becoming more common. These native species do not have protective foliage like gorse and expose wētā to higher rates of predation than when taking refuge in gorse (Chapter 3). MGW are already using native species among the gorse as diurnal refuge sites (Chapter 3 ) and as the natives become more abundant, their use of these species and subsequent exposure to mammalian predators may increase. Alternatively, it could be a combination of factors or something else that has not been identified yet. 


\subsubsection{Abiotic impacts on MGW occupancy and detection}

We used single-season occupancy models to assess the effect of abiotic factors on occupancy and detection rates in 2005 and 2018. For both years, no factors were found to influence detection probabilities of MGW in the MGWSR. Plot location was found to be an influential covariate for the occupancy of MGW in 2018, whereby edge plots where more likely to be occupied (Appendix 2.5). In tree and alpine wētā species, abiotic and biotic factors have been linked to their occupancy or presence. Abiotic factors such as canopy cover, sub-canopy density, and vegetation species presence have been identified as important factors effecting occupancy of tree wētā (Hemideina ricta and $\mathrm{H}$. thoracica) in artificial refuges within remnant forests (Bowie et al., 2014; Wehi et al., 2015). Similarly, the size of rock slabs and presence of other invertebrates has been linked to the presence of alpine wētā (Hemideina maori) on the Rock and Pillar Range, central Otago (Sinclair et al., 2001). In 2005 no covariates were found to be important in predicting MGW occupancy probability, suggesting occupancy was approximately evenly distributed throughout the reserve.

The strong RVI associated with the covariate 'location' in the 2018 MGW occupancy model suggests wētā are now more likely to be occupying monitoring sites in edge habitat $(<30 \mathrm{~m}$ from firebreak, clearing, or boundary). This increased occupancy in edge habitat compared to 2005 could be a result of fewer wētā and wētā being found in preferred or safer sites. Edge habitats are considered more productive and nutrient rich than interior habitats, which is often reflected in the abundance and richness of species, including invertebrates (Kremsater \& Bunnell, 1999; Horvath et al., 2002). Goats regularly browse the gorse edge and small birds are often present resulting in increased nutrient input (dung) that may be beneficial for omnivorous wētā (Richards, 1994; Mclntyre, 2001). Furthermore, new nutrient rich gorse shoots encouraged by goat browse may be a preferred food source of the wētā (Richards, 1994; Stronge et al., 1997). A similar pattern has been observed in Wellington tree wētā (H. crassidens) on Matiu-Somes Island (Wellington), where the distributional shift of the translocated population was attributed to nutritional availability on the island (Watts et al., 2008a; Watts et al., 2017). Edge habitat may have also been preferred by wētā in 2005, but was not detected due to the presence-absence of wētā being examined rather than density. The lack of influential covariates for detection probabilities suggest the probability of 
detecting wētā within plots, provided they are present, should be approximately equal between sites and not affected by the 'day', 'weather' or 'observer', according to the models. The area of which occupancy is modelled in the field can be quite fuzzy, depending on the species and monitoring method used (D MacKenzie, pers. comm., 2019). For example, fiveminute bird counts give an occupancy measure of birds within an unknown area (D MacKenzie, pers. comm., 2019). As long as the call can be heard by the observer, the bird is noted present, even if it is not in the general vicinity of the observer (D MacKenzie, pers. comm., 2019). For MGW, it has been assumed that wētā will not move in or out of the monitoring plots over the five consecutive monitoring days. However, from the assessment of MGW movement data collected in this study (Chapter 3), we suggest this is not the case.

MGW radiotracked in autumn 2018 were found to move on average $1.57-5.11 \mathrm{~m}$ over 48 hours (Chapter 3). This is a conservative estimate as wētā likely move further between dayfixes (C Watts, pers. comm., 2018). Over five days, we estimate a wētā could move on average $3.93-12.78 \mathrm{~m}$, which is far enough to move in or out of the monitoring plot, depending on the wētā's starting location. For example, in a simulation assessing the probability a MGW will remain inside a $3 \mathrm{~m}$ radius monitoring plot based on a random start point (Appendix 2.8), if a wētā moves just one $1 \mathrm{~m}$ overnight there is a $79 \%$ chance the wētā will remain inside the monitoring plot. Conversely, if a MGW was to move $5 \mathrm{~m}$ overnight, there is only a $10 \%$ chance the wētā will remain inside the monitoring plot (Appendix 2.8). This means a MGW could be present within the monitoring plot on the second search day, but outside in the surrounding habitat on the remaining four days (Appendix 2.9). Therefore, you are not failing to detect the animal on the later days as the model predicts, the animal is just no longer present within the monitoring plot (D MacKenzie, pers. comm., 2019).

As a result, the area being assessed for MGW occupancy is in fact larger than the $3 \mathrm{~m}$ radius monitoring plot (Appendix 2.9). Taking into account the known average distance and movement pattern (random diffusion) of MGW (Chapter 3), we estimate this area could be up to $782 \mathrm{~m}^{2}$ (15.78m radius circle), conservatively. 


\subsubsection{Mammal monitoring}

Mammalian pest species are not controlled within the MGWSR, except for sporadic possum control, and appear to be present year-round, peaking in summer and autumn. As mentioned above (section 2.5.2), this could be having an adverse effect on the MGW population. Despite the unique situation in the MGWSR, MGW do not always fare well in gorse habitat where mammalian predators are present and goat numbers are low resulting in little foliage browse. For example, MGW translocated to gorse dominated sites, Cowan's and Tikikaru (both private land), in the early 1990's and 2000's, respectively, did not establish (Watts \& Thornburrow, 2009). Mammalian pests and few to no goats were present at both sites (Watts \& Thornburrow, 2009). The presence of both species seems to be import in determining the establishment of translocated populations (Watts \& Thornburrow, 2009). Moreover, in this study, we recorded a $30 \%$ predation rate of radiotracked MGW in gorse habitat during autumn in the MGWSR (Chapter 3).

Other large-bodied invertebrates have generally shown suppression trends, in some cases leading to extinction, in the presence of mammalian predators. For example, rodents have been implicated in the suppression of Oclandius species (Coleoptera) on Auckland Island, and the extinction of the once abundant endemic weevil Hadramphus stilbocarpae from Big South Cape Island (Kuschel \& Worthy, 1996). The introduction of mammalian predators has been linked to the decline of the endemic terrestrial flax snail Placostylus hongii on Motuhoropapa Island (Moors, 1985) and the local extinction of Amborhytida tarangensis and P. hongii from Lady Alice Island (Brook, 1999). Furthermore, a significant increase in Wellington tree wētā ( $H$. crassidens), from 4.4 to 6.9 wētā per $\mathrm{m}^{2}$, was recorded following the eradication of rats on Nukuwaiata Island, Cook Straight, suggesting rats were supressing the population (Gibbs, 2009).

From modelling MGW occupancy over the past 14 years we confirmed the population in Mahoenui is declining, but the cause is not clear. Mammalian predators are present yearround within the reserve, however, lack of gorse browse, few goats, and the increase in native vegetation could also be contributing factors. Furthermore, we identified that MGW were more likely to occupy edge plots in 2018 , where refuge conditions may be preferred or safer for wētā. From these results, we recommend the immediate implementation of pest control and habitat management (e.g. gorse gardening, increased goat numbers; see Chapter 5) to 
attempt to prevent further decline of the population. Long-term species management (e.g. predator excluding fence, translocations, captive breeding; see Chapter 5) and ongoing monitoring is also recommended along with further research into population genetics and monitoring techniques for detecting MGW in native habitat. 


\subsection{Appendices}

Appendix 2.1 Naïve detection estimates of MGW from annual monitoring data collected by DOC (2005 - 2016). Graph taken from DOC (2016a).

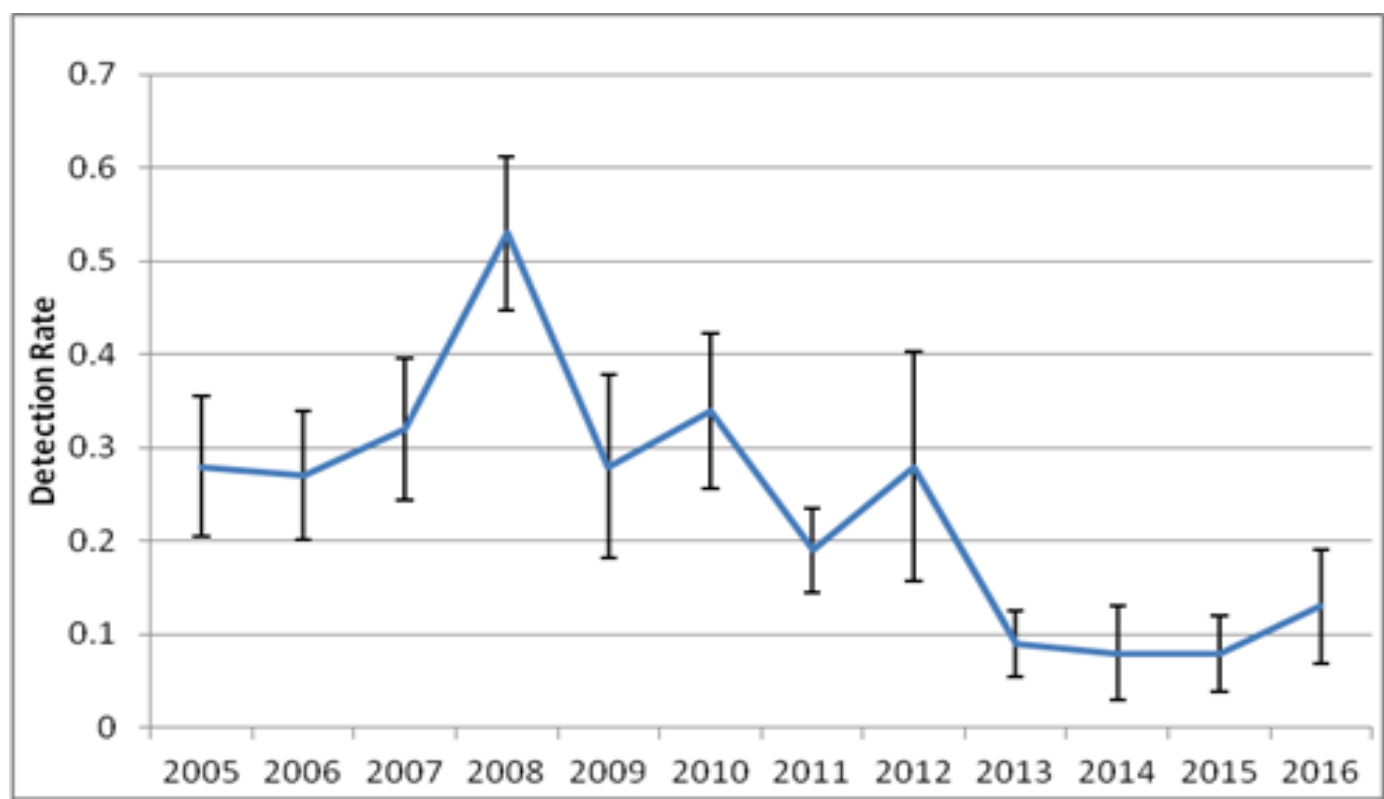

Appendix 2.2 Maximum search times applied to monitoring plot for years 2005 and 20142018. Blue and red shading indicates a search time has increased or decreased, respectively, from the previous year.

\begin{tabular}{l|cccccc}
\hline Plot & $\mathbf{2 0 0 5}$ & $\mathbf{2 0 1 4}$ & $\mathbf{2 0 1 5}$ & $\mathbf{2 0 1 6}$ & $\mathbf{2 0 1 7}$ & $\mathbf{2 0 1 8}$ \\
\hline $\mathbf{1}$ & 10 & 10 & 10 & 10 & 10 & 5 \\
$\mathbf{2}$ & 5 & 5 & 10 & 10 & 10 & 5 \\
$\mathbf{3}$ & 10 & 10 & 10 & 10 & 10 & 5 \\
$\mathbf{4}$ & 5 & 5 & 10 & 10 & 10 & 10 \\
$\mathbf{5}$ & 20 & 20 & 20 & 20 & 20 & 15 \\
$\mathbf{6}$ & 15 & 15 & 15 & 15 & 15 & 10 \\
$\mathbf{7}$ & 10 & 10 & - & - & - & - \\
$\mathbf{8}$ & - & 10 & - & - & - & - \\
$\mathbf{9}$ & 20 & - & - & - & - & - \\
$\mathbf{1 0}$ & 10 & 10 & - & - & - & - \\
$\mathbf{1 1}$ & 15 & 10 & - & - & - & - \\
$\mathbf{1 2}$ & - & 10 & 5 & 5 & 5 & 5 \\
$\mathbf{1 3}$ & 10 & 10 & 10 & 10 & 10 & 5 \\
$\mathbf{1 4}$ & 5 & 5 & 5 & 5 & 5 & 5 \\
$\mathbf{1 5}$ & 15 & 10 & 10 & 10 & 10 & 5 \\
$\mathbf{1 6}$ & 10 & 10 & - & - & - & - \\
$\mathbf{1 7}$ & 15 & 10 & - & - & - & - \\
$\mathbf{1 8}$ & 5 & 5 & - & - & - & -
\end{tabular}




\begin{tabular}{|c|c|c|c|c|c|c|}
\hline 19 & 5 & 5 & - & - & - & - \\
\hline 20 & 15 & 15 & 15 & 15 & 15 & 10 \\
\hline 21 & 10 & 10 & - & - & - & - \\
\hline 22 & 15 & 15 & - & - & - & - \\
\hline 23 & 10 & 10 & 15 & 15 & 15 & 15 \\
\hline 24 & 5 & 5 & - & - & - & - \\
\hline 25 & 10 & 10 & - & - & - & - \\
\hline 26 & 15 & 15 & 15 & 15 & 15 & 15 \\
\hline 27 & 5 & 5 & 5 & 5 & 5 & 10 \\
\hline 28 & 15 & 15 & 15 & - & - & 15 \\
\hline 29 & 10 & 10 & 10 & 10 & 10 & 10 \\
\hline 30 & 5 & 5 & 5 & 5 & 5 & 5 \\
\hline 31 & 15 & 10 & 10 & 10 & 10 & 5 \\
\hline 32 & 5 & 5 & 5 & 5 & 5 & 5 \\
\hline 33 & 10 & 10 & 10 & 10 & 10 & 15 \\
\hline 34 & 10 & 10 & 5 & 5 & 5 & 10 \\
\hline 35 & 10 & 5 & 5 & 5 & 5 & 5 \\
\hline 36 & 5 & 5 & 5 & 5 & 5 & 5 \\
\hline 37 & 20 & 20 & 20 & 20 & 20 & 15 \\
\hline 38 & 5 & 5 & 5 & 5 & 5 & 5 \\
\hline 39 & 20 & 20 & 20 & 20 & 20 & 20 \\
\hline 40 & 15 & 15 & 15 & 15 & 15 & 15 \\
\hline 41 & 10 & 10 & 10 & 10 & 10 & 10 \\
\hline 42 & 10 & 10 & 5 & 5 & 5 & 5 \\
\hline 43 & - & 10 & 10 & 10 & 10 & 10 \\
\hline 44 & 10 & 10 & 10 & 10 & 10 & 15 \\
\hline 45 & 10 & 10 & 10 & 10 & 10 & 10 \\
\hline 46 & 15 & 15 & 15 & 15 & 15 & 15 \\
\hline 47 & 10 & 10 & 10 & 20 & 20 & 20 \\
\hline 48 & 15 & 15 & 15 & 15 & 15 & 15 \\
\hline 49 & 10 & 10 & 10 & 10 & 10 & 10 \\
\hline 50 & 10 & 10 & 10 & 10 & 10 & 10 \\
\hline 51 & 10 & 10 & 5 & 5 & 5 & 5 \\
\hline 52 & 15 & 15 & 20 & 20 & 20 & 15 \\
\hline 53 & 10 & 10 & 10 & 10 & 10 & 15 \\
\hline 54 & 15 & 15 & 15 & 10 & 10 & 5 \\
\hline 55 & 15 & 5 & - & - & - & - \\
\hline 56 & 5 & - & - & - & - & 15 \\
\hline 57 & 20 & 20 & 15 & 15 & 15 & 20 \\
\hline 58 & 10 & 10 & 10 & 10 & 10 & 10 \\
\hline 59 & 15 & 15 & 15 & 15 & 15 & 15 \\
\hline 60 & 15 & - & - & 15 & 15 & 15 \\
\hline 61 & 10 & 10 & - & - & - & - \\
\hline 62 & 5 & 10 & 10 & 10 & 10 & 10 \\
\hline 63 & 20 & 20 & 20 & 20 & 20 & 20 \\
\hline 64 & 10 & 5 & - & - & - & - \\
\hline
\end{tabular}




\begin{tabular}{|c|c|c|c|c|c|c|}
\hline 65 & 10 & 5 & - & - & - & - \\
\hline 66 & 20 & 20 & 10 & 10 & 10 & 10 \\
\hline 67 & - & 10 & 10 & 10 & 10 & 10 \\
\hline 68 & 15 & 15 & 15 & 15 & 15 & 15 \\
\hline 69 & 20 & 20 & 15 & 15 & 15 & 15 \\
\hline 70 & - & 10 & 5 & 5 & 5 & 5 \\
\hline 71 & 10 & 5 & - & - & - & - \\
\hline 72 & 15 & 15 & - & 20 & 20 & 20 \\
\hline 73 & - & 15 & 15 & 15 & 15 & 15 \\
\hline 74 & 15 & 10 & 10 & 5 & 5 & 5 \\
\hline 75 & 15 & 15 & 10 & 10 & 10 & 10 \\
\hline 76 & NA & NA & NA & NA & 20 & 20 \\
\hline 77 & NA & NA & NA & NA & 15 & 15 \\
\hline 78 & NA & NA & NA & NA & 15 & 15 \\
\hline 79 & NA & NA & NA & NA & 15 & 10 \\
\hline 80 & NA & NA & NA & NA & 10 & 10 \\
\hline 81 & NA & NA & NA & NA & 15 & 15 \\
\hline 82 & NA & NA & NA & NA & 15 & 10 \\
\hline 83 & NA & NA & NA & NA & 15 & 10 \\
\hline 84 & NA & NA & NA & NA & 10 & 10 \\
\hline 85 & NA & NA & NA & NA & 10 & 10 \\
\hline 86 & NA & NA & NA & NA & 10 & 10 \\
\hline 87 & NA & NA & NA & NA & 10 & 10 \\
\hline 88 & NA & NA & NA & NA & 5 & 5 \\
\hline 89 & NA & NA & NA & NA & 15 & 15 \\
\hline 90 & NA & NA & NA & NA & 15 & 15 \\
\hline 91 & NA & NA & NA & NA & 15 & 10 \\
\hline 92 & NA & NA & NA & NA & 5 & 10 \\
\hline 93 & NA & NA & NA & NA & 10 & 10 \\
\hline 94 & NA & NA & NA & NA & 10 & 10 \\
\hline 95 & NA & NA & NA & NA & 15 & 15 \\
\hline 96 & NA & NA & NA & NA & 10 & 10 \\
\hline 97 & NA & NA & NA & NA & 10 & 10 \\
\hline 98 & NA & NA & NA & NA & 20 & 20 \\
\hline 99 & NA & NA & NA & NA & 10 & 10 \\
\hline 100 & NA & NA & NA & NA & 10 & 10 \\
\hline
\end{tabular}


Appendix 2.3 Gorse structure classification from Sutton (2004). a) Browsed - small gorse bush rounded due to heavy browsing. b) Semi-browsed - >30\% of the gorse bush under $1 \mathrm{~m}$ is browsed. Above $1 \mathrm{~m}$, the bush is unbrowsed and branching. c) Unbrowsed - gorse bush branching and sprawling due to lack of browsing. Drawn images of browse categories taken from Sutton 2004.
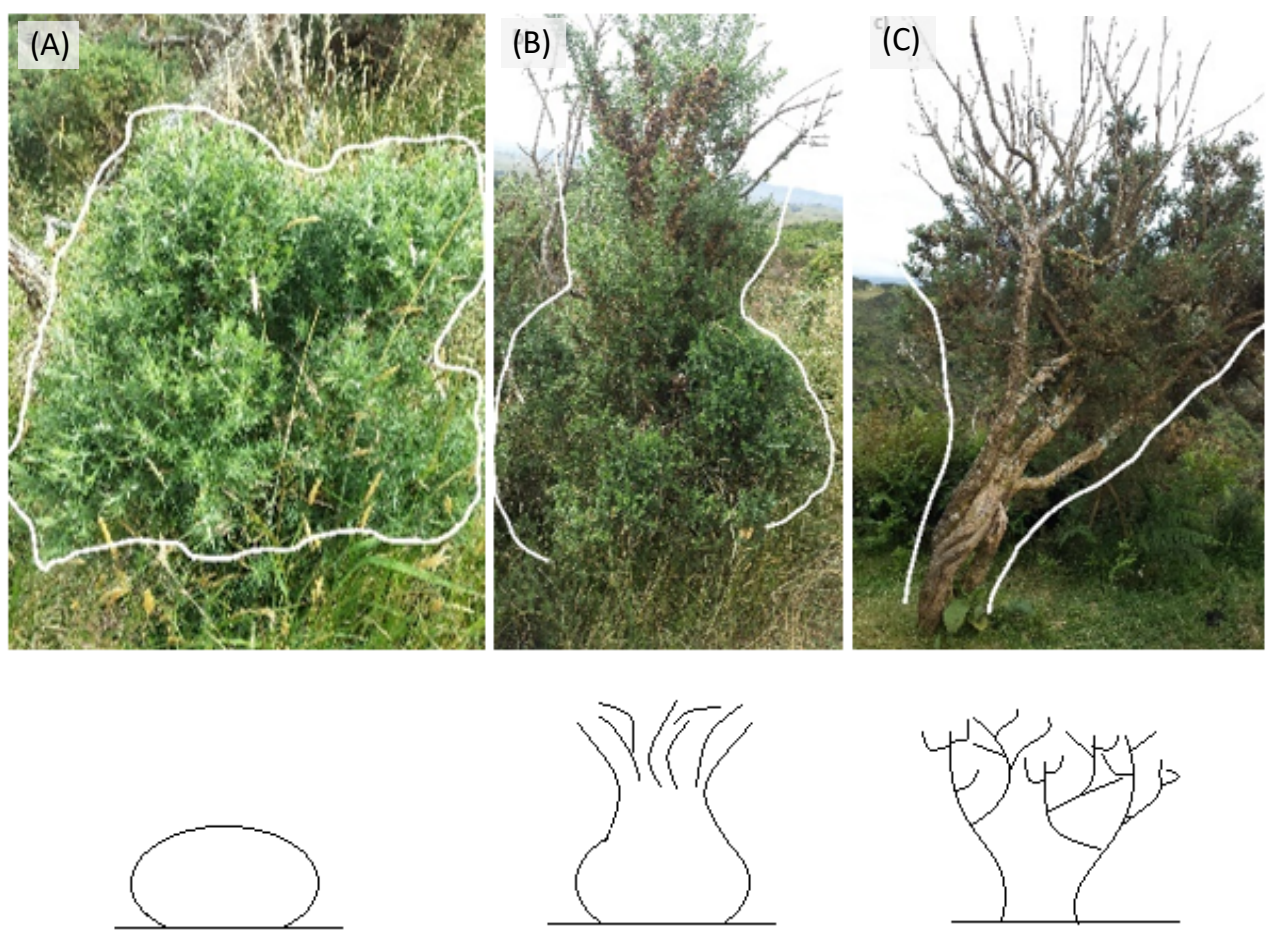

Appendix 2.4 Location of rodent monitoring tracking tunnels in the MGWSR. Yellow and green triangles represent tunnels in gorse habitat and native habitat, respectively.
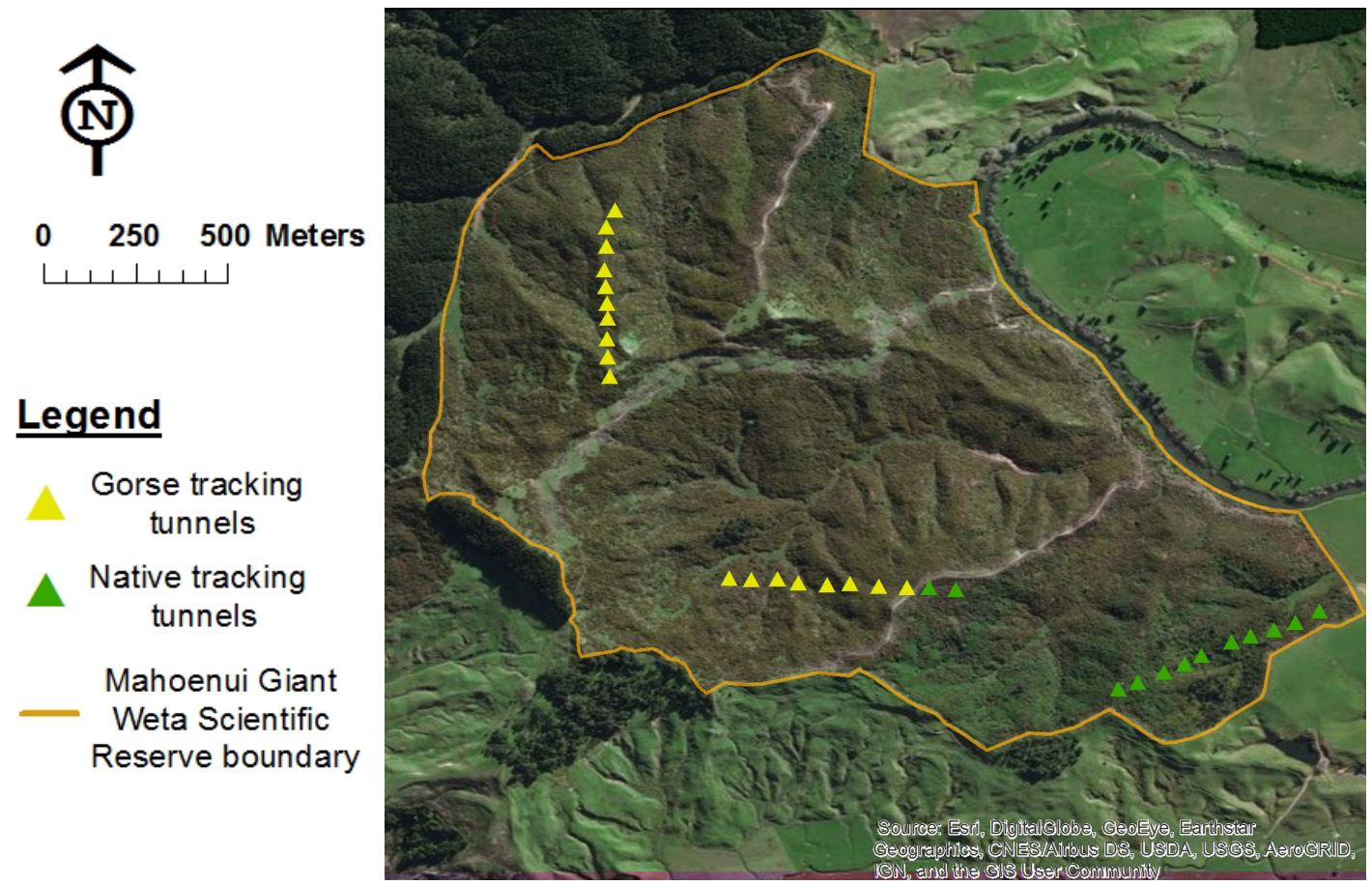
Appendix 2.5 Location of edge and interior monitoring plots in 2005 and 2018. Plots were considered 'edge' plots if they were less than $30 \mathrm{~m}$ from the boundary of the reserve, edges of firebreaks or clearings.
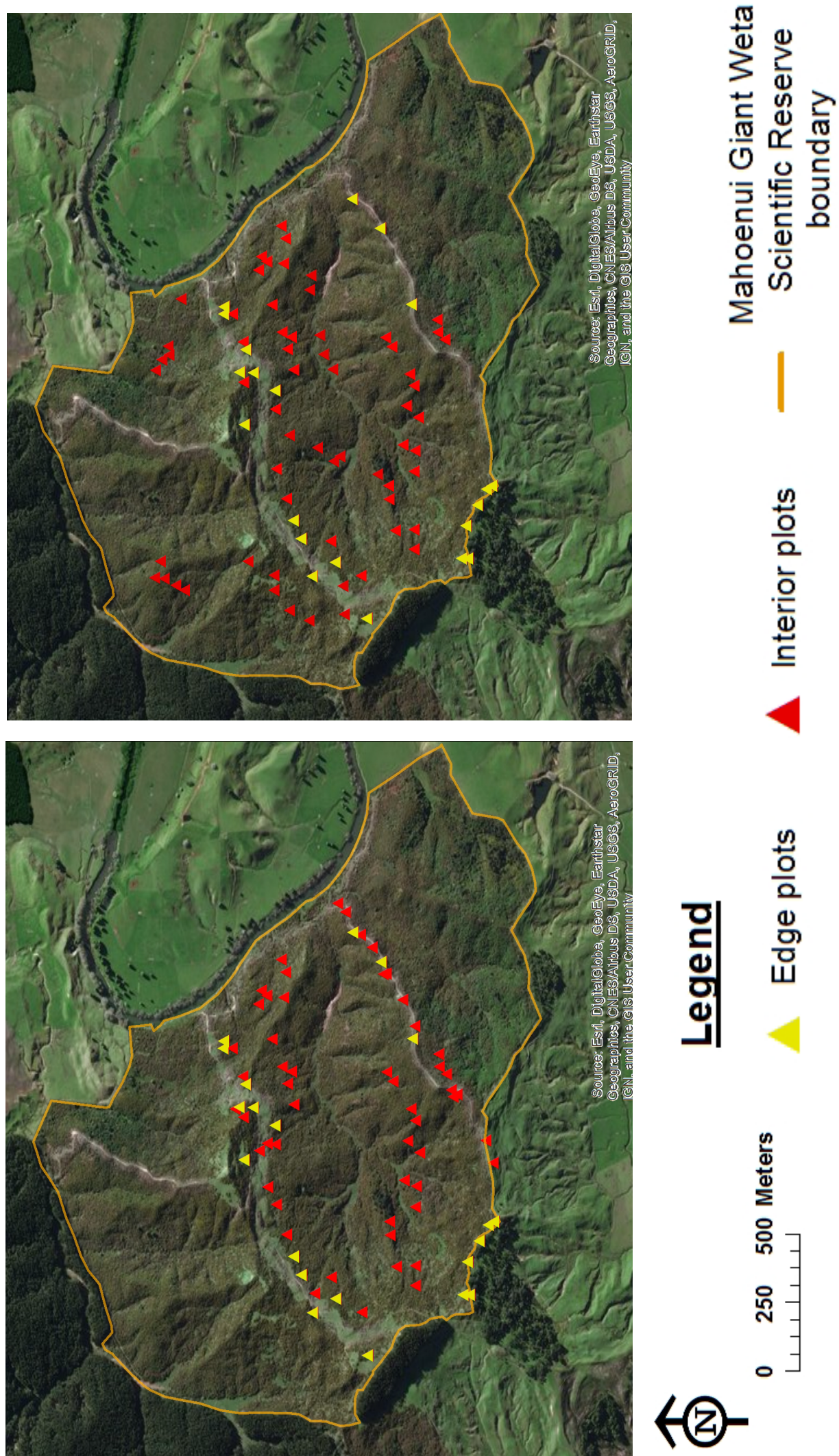

(2)- 
Appendix 2.6 Monitoring plots (white triangles) where MGW were detected one, two, three, or four times during annual monitoring in (A) 2005, (B) 2010, (C) 2015, and (D) 2018.
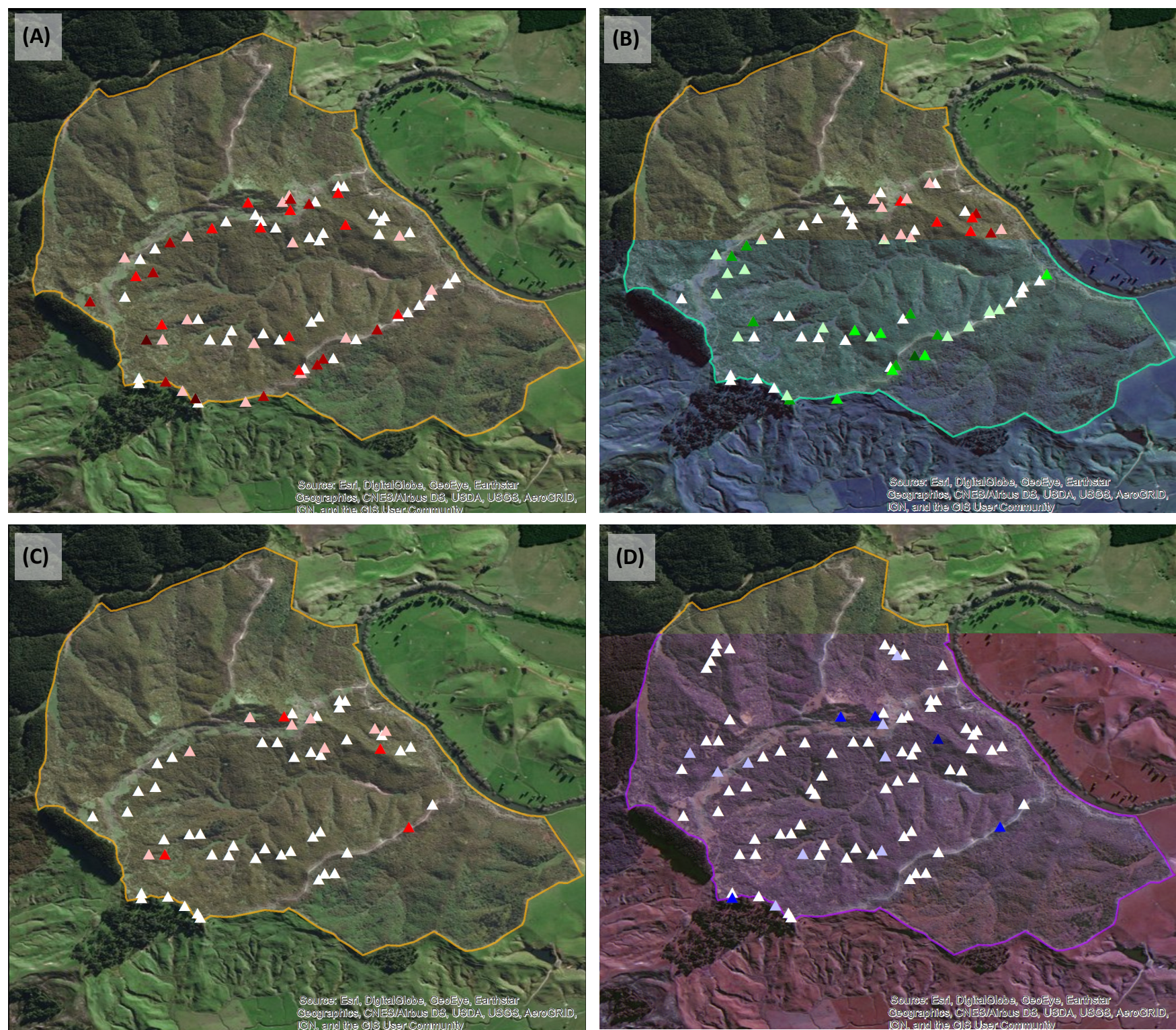

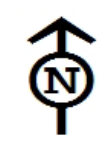

\section{Legend}

0 $250 \quad 500$ Meters
Ane detection

$\triangle$ Four detections
A Two detections

Mahoenui Giant Weta

Scientific Reserve

boundary

\section{A Three detections}


Appendix 2.7 Change in the number of monitoring plots where one, two, three, four, or no detections of MGW were recorded during five-day annual monitoring searches (2005-2018). The number of plots where no wētā were detected has increased by $4 \%$ each year. The number of plots where one, two, or three wētā were detected has decreased by 1\% each year. Four detections per plot are rarely recorded.
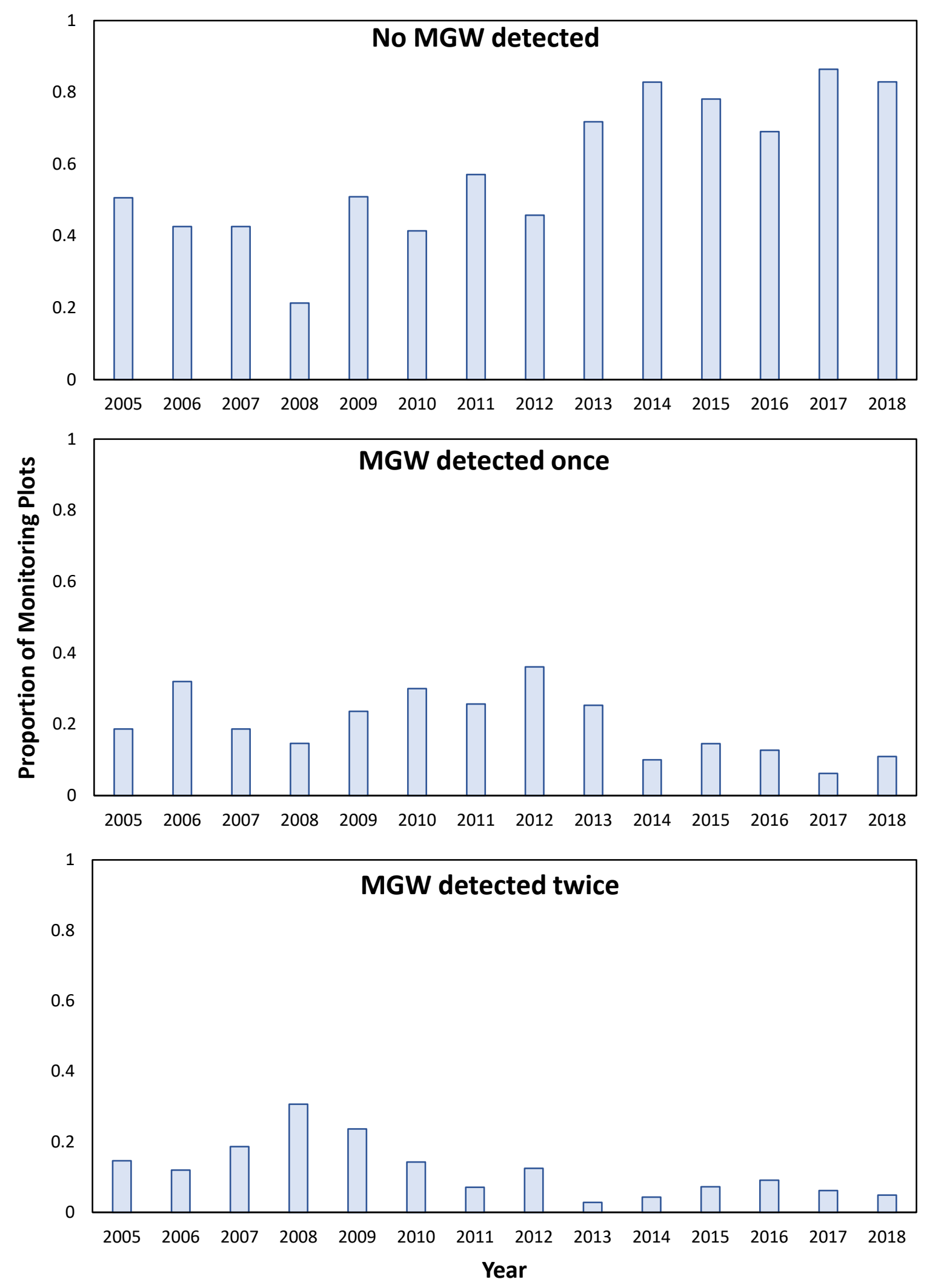


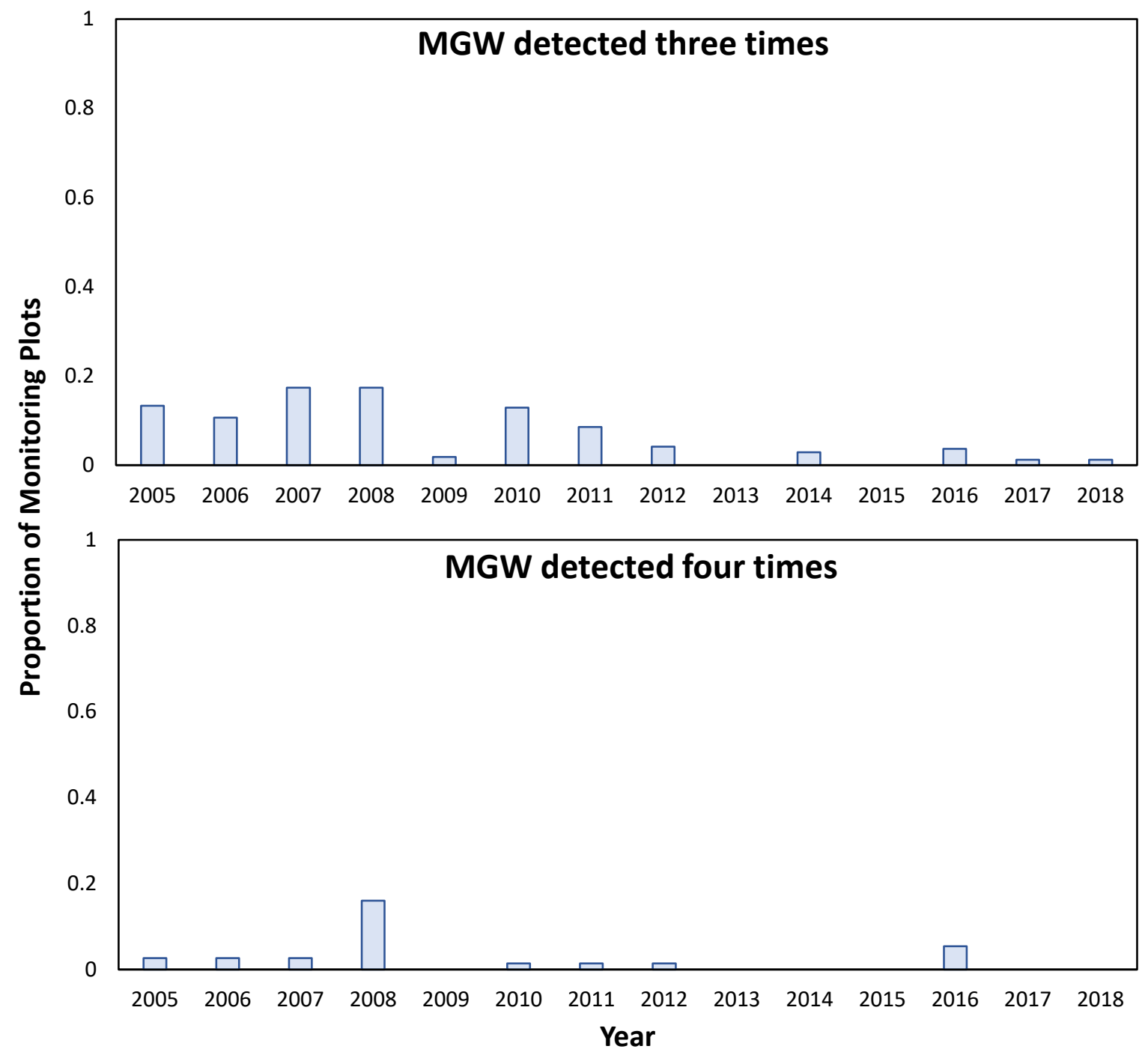


Appendix 2.8 Simulation of the probability a MGW will remain inside a $3 \mathrm{~m}$ radius monitoring plot based on a random start position within in the plot for a variety of step lengths $(0-6.75 \mathrm{~m})$. Simulation done by Stephen Hartley (VUW).

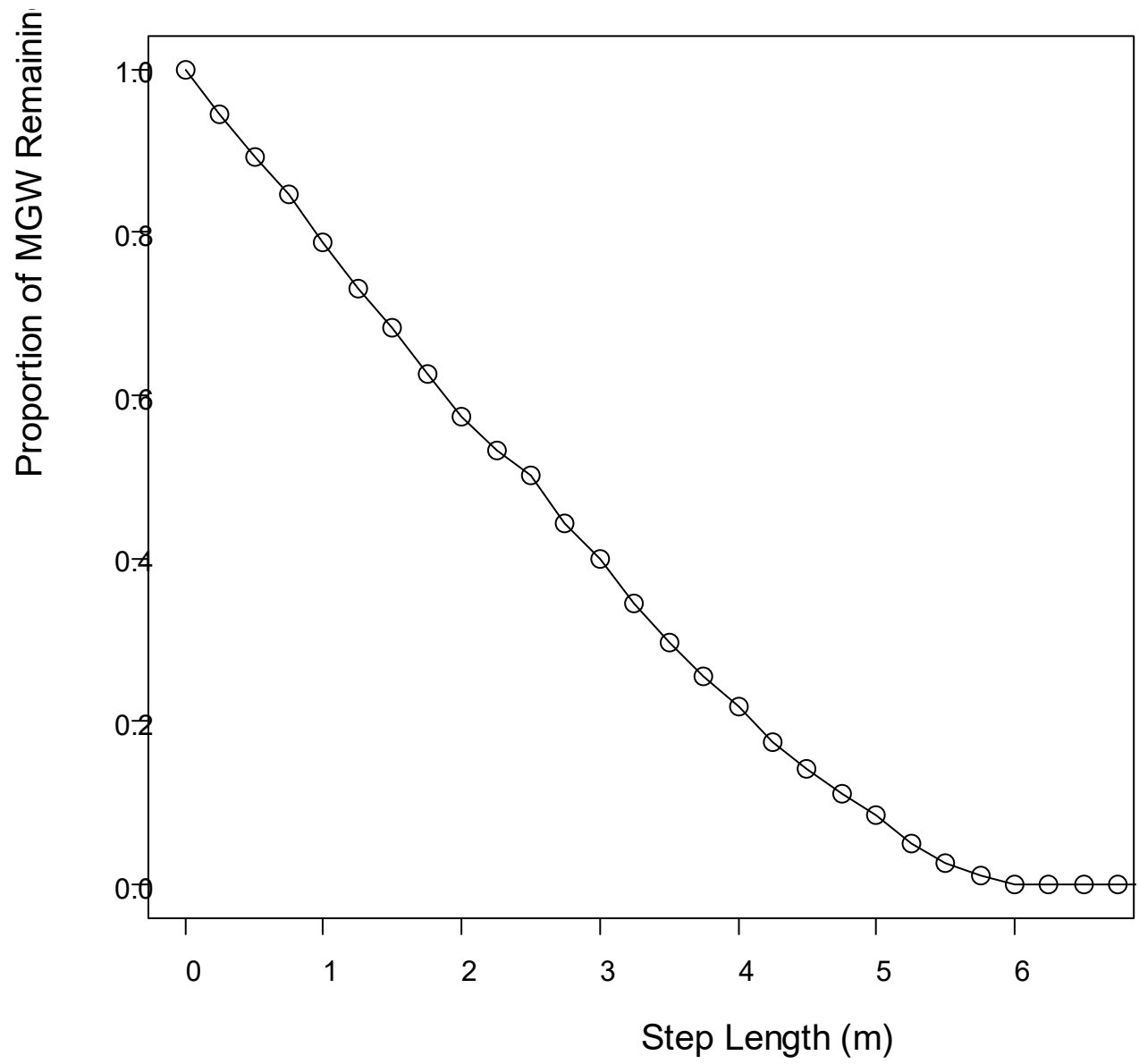


Appendix 2.9 Example of a MGW movement over five consecutive monitoring days, based on known autumn movement distances and patterns. The Inner solid circle and the middle open circle represent the centre and boundary of the $3 \mathrm{~m}$ radius monitoring plot, respectively. The numbers above the wētā represent the monitoring day and red arrows show the direction of movement. The outer dashed circle shows the actual area the occupancy model is modelling estimates for when accounting for the assumption that no wētā are moving in or out of the search area (i.e. if a wētā is detected on one of the search days, but not on the others it is treated as a failed detection).

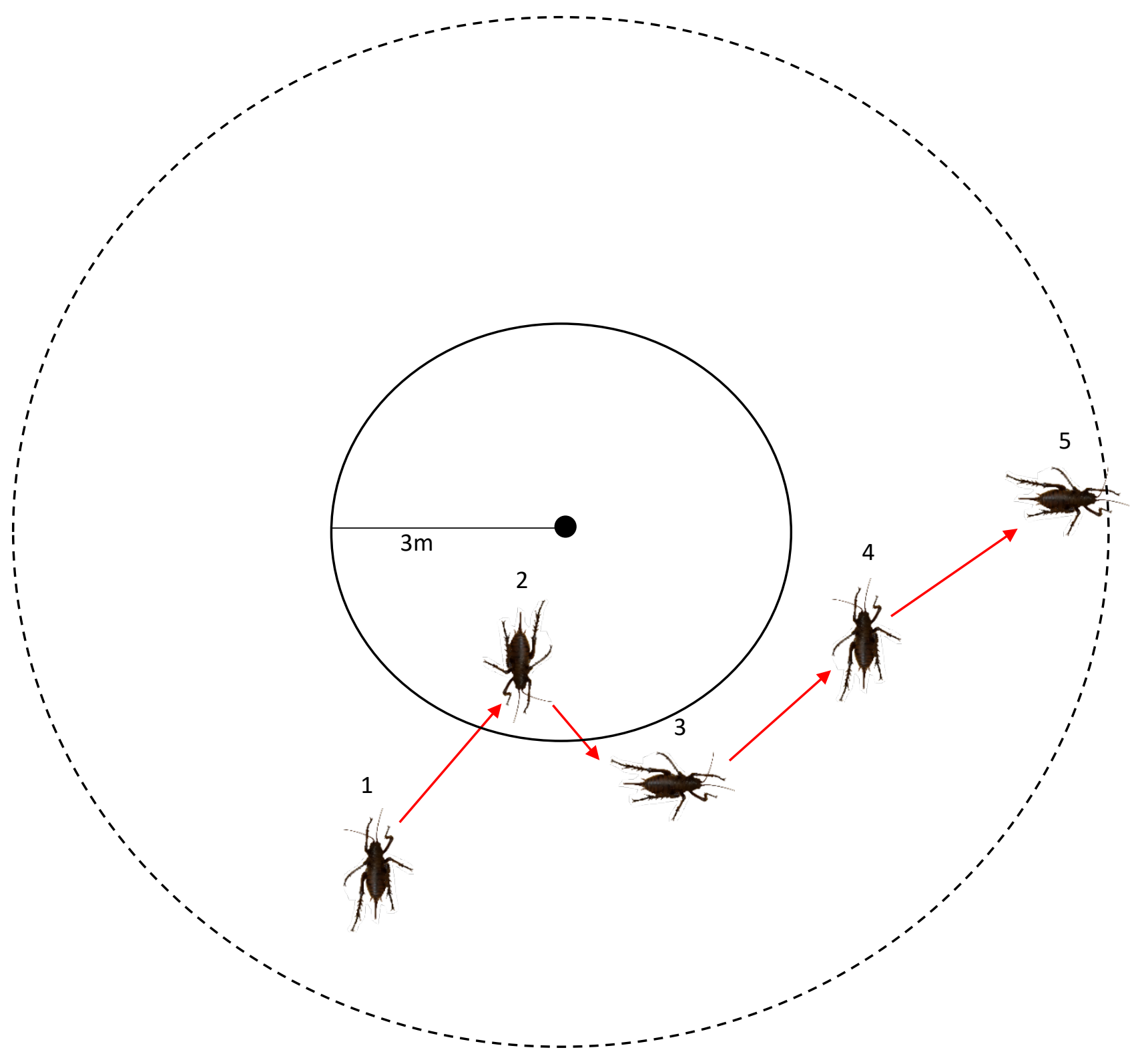





\section{Chapter 3 - Survival and behaviour of Mahoenui giant wētā (Deinacrida mahoenui) in gorse and native vegetation habitats}

\subsection{Abstract}

The last remaining individuals of the original Mahoenui giant wētā (MGW; Deinacrida mahoenui) population are currently restricted to an 187ha mainland reserve in Mahoenui, western King Country, New Zealand. Having sought refuge in the introduced woody shrub, gorse (Ulex europaeus), these wētā have survived in the presence of introduced mammalian predators for almost six decades. However, due to natural succession, the reserve is gradually reverting to native bush and monitoring of wētā shows potential signs of population decline. Concerns for the species survival have been raised as it is unknown how wētā will cope in an altered habitat alongside mammalian predators. We assessed survival rates, movement patterns, and diurnal refuge use of MGW in both gorse and native vegetation in summer $(n=14)$, autumn $(n=31)$, and spring $(n=10)$ using VHF transmitters. Survival rates, in relation to predation, showed MGW inhabiting native vegetation in the presence of mammalian predators were nine times more likely to be predated than those inhabiting gorse. Assessment of MGW movement revealed wētā move less in autumn ( 3m/48hrs) compared to summer ( $\sim 10 \mathrm{~m} / 48 \mathrm{hrs})$ and spring ( $\sim \mathrm{m} / 48 \mathrm{hrs})$, and most commonly follow movement patterns consistent with random diffusion. Diurnal refuge use revealed MGW take refuge above $2.5 \mathrm{~m}$ in the canopy of native vegetation, whereas wētā in gorse habitat were commonly found around $1.5 \mathrm{~m}$ in the denser foliage of unbrowsed bushes. Furthermore, no radiotracked wētā were observed with another individual in autumn, compared to eight and 26 observations of pairs in summer and spring, respectively. These results provide crucial survival and behavioural information, from which we make management recommendations and suggest further research avenues. 


\subsection{Introduction}

The introduction of mammalian pests such as rats (Rattus spp.), house mice (Mus musculus), brushtail possums (Trichosurus vulpecula), and mustelids (Mustela spp.) has had a devastating effect on much of New Zealand's native fauna (St Clair, 2011; Innes et al., 2012; O'Donnell \& Hoare, 2012; Reardon et al., 2012). Rodents in particular, have been implicated in the decline and extinction of many invertebrate species from the New Zealand mainland (Bremner et al., 1984; Brook, 1999; Gibbs, 2001; St Clair, 2011). Large-bodied invertebrates such as giant wētā (Anostostomatidae: Deinacrida) are particularly vulnerable due to their profitability as a food source and ineffective anti-predator adaptations (Gibbs, 1998; St Clair, 2011). As a result, approximately $80 \%$ (9/11) of Deinacrida species are now of conservation concern, but there is limited knowledge to assist conversation efforts due to poor representation in the literature (St Clair, 2011; Trewick et al., 2016).

The Mahoenui giant wētā (MGW; Deinacrida mahoenui) is one such species that is potentially at risk of extinction. The last naturally occurring population is restricted to a 187ha mainland reserve (Mahoenui Giant Wētā Scientific Reserve; MGWSR) near Mahoenui, western King Country, New Zealand (Watts et al., 2013). The introduced woody shrub gorse (Ulex europaeus) dominates the majority of the reserve. Its spiny, dense foliage is thought to provide refuge to these wètā, allowing the population to successfully survive in the presence of mammalian predators for almost six decades (Sherley \& Hayes, 1993; Stronge et al., 1997; Watts \& Thornburrow, 2009).

However, due to natural succession, the reserve is gradually reverting to native bush (Sullivan et al., 2007). Of the reserve's three valleys, the southernmost is already completely dominated by native trees and ferns, and in recent years tree ferns (Dicksonia fibrosa and Cyathea spp.) and ground ferns have become noticeably more present throughout the northern and middle valleys (Quinnell, 2015; DOC, 2016). There are concerns that the lack of protective foliage in the native vegetation may expose wētā to higher levels of predation (Watts \& Thornburrow, 2009). Furthermore, annual monitoring data collected by the Department of Conservation (DOC) suggests signs of population decline, and there is no regular pest control in the reserve except for periodic possum control for bovine tuberculosis (TB) management (Quinnell, 2015; Chapter2). 
Numerous translocations have been attempted in the past with over 2000 MGW being moved to seven locations (see Watts \& Thornburrow, 2009). However, only translocations to two pest-free or near pest-free locations resulted in successful establishment of insurance populations (Watts \& Thornburrow, 2009). A more recent translocation to Sanctuary Mountain Maungatautari was undertaken in 2012/2013 (Watts, 2012, 2013), but the population is probably still in the establishment phase (C Watts, pers. comm., 2019). With limited research on this threatened species, it is important to understand survival and behaviour in gorse and native vegetation to assist with future management.

Radio transmitters are a valuable tool for monitoring animals in the field and have been previously used to monitor a range invertebrates (Lepidoptera (Liegeois et al., 2016), Coleoptera (Hedin \& Ranius, 2002), Hymenoptera (Hagen et al., 2011), Odonata (Levett \& Walls, 2011), and Orthoptera (Fornoff et al., 2012)), including giant wētā species (D. mahoenui, (Richards, 1994); D. rugosa (Mclntyre, 2001; Kelly et al., 2008; Watts et al., 2011; Watts et al., 2012); and D. heteracantha (Gibbs \& Mclntyre, 1997; Watts \& Thornburrow, 2011)). Transmitters allow the observer to monitor an individual's survival and behaviour over time. For example, Watts et al. (2012) monitored 36 adult Cook Strait giant wētā (D. rugosa) over 72 days following translocation into Karori Sanctuary (Wellington, New Zealand) in 2007 and 2008. Individual movement and behaviour was recorded during radiotracking, providing data that was used to assess the establishment phase of the population (Watts et al., 2012).

In this study, transmitters were used to monitor 55 adult MGW in the MGWSR during summer (2016/2017), autumn (2018), and spring (2018). Our objectives were to (1) determine survival rates, in relation to predation, of MGW in both gorse and native habitats, (2) assess MGW movement patterns, and (3) assess MGW diurnal refuge use. These data would allow us to infer whether these MGW could successfully survive in the native vegetation and provide much needed behavioural knowledge.

Henceforth, Mahoenui giant wētā will be referred to as MGW or wētā. Other species will be referred to by their full common name and/or scientific name e.g. Auckland tree wētā (Hemideina thoracica). 


\subsection{Methods}

\subsubsection{Study site}

Refer to chapter 2.

\subsubsection{Wètā capture and housing}

Wētā used in this study were caught by searching gorse bushes within the northern and middle valleys of the MGWSR. Pronotum length, head width, and weight were measured using $30 \mathrm{~cm}$ callipers and a 30-gram Pesola scale (Appendix 3.1). Instar (wētā age) was determined visually and by comparison to MGW measurement ranges from Richards (1994) and Sherley and Hayes (1993; Appendix 3.2). Only wētā identified as $10^{\text {th }}$ instar, being adults and no longer requiring to moult, were collected. Males were required to weigh more than seven grams, being large enough to carry a transmitter without impairment $(<10 \%$ of individuals body weight; Sedgeley et al., 2012; DOC, 2017). Adult females always weighed more than seven grams (10-16g).

Collected wētā were housed in plastic containers ( $2 \mathrm{~L}$ in volume) with a damp paper towel and a few mahoe leaves. Small holes were made in the lid for ventilation. Wētā were transported off-site to a local address for transmitter attachment and kept for no longer than 48 hours before being returned to the reserve and released.

\subsubsection{Transmitter attachment}

Transmitters (Holohil Systems LTD, Model: BD-2, 0.62g), were attached to wētā using the following methods, as described in Watts and Thornburrow (2011) and Watts et al., (2012; Appendix 3.3). A thickened aluminium saddle was cut to the size of the wētā's pronotum. Pronotum and saddle surfaces were roughened with fine sandpaper to aid adhesion. A small amount of superglue (Selleys ${ }^{\circledR}$ Supa Glue ${ }^{\text {TM }}$ Gel) was used to attach the saddle to the pronotum, avoiding glue getting elsewhere on the wētā. After an hour of setting time, the transmitter was attached to the saddle using silicone sealant (Selleys ${ }^{\circledR}$ Roof \& Gutter Silicone Sealant). The transmitter's aerial $(160 \mathrm{~mm}$ long) ran parallel to the wētā's ventral surface towards the posterior and all edges of the transmitter were sealed over to prevent the wētā 
getting caught on any substrate. After attachment, the wētā was returned to its holding container for a minimum of three hours before release to allow the sealant to set. Transmitter batteries were expected to last approximately 21 days.

\subsubsection{Release categories}

Wētā were randomly allocated into one of three release categories; 1 ) original site of capture in gorse habitat (original gorse), 2) translocated into unfamiliar gorse habitat (translocated gorse), 3) translocated into unfamiliar native habitat (natives; Table 3.1). This allowed for comparison between the wētā's current known habitat (gorse) and other habitat present within the MGWSR (native vegetation), whilst testing for a possible translocation effect (original versus translocated gorse). An equal sex split was maintained between wētā translocated into gorse and native habitats.

Due to ethical concerns for the survival of the wētā, no wētā were translocated into unfamiliar native habitat during the spring 2018 radiotracking period, as high predation rates were observed in native vegetation during the preceding autumn 2018 radiotracking period. Hence, the final radiotracking period was aimed at increasing the overall sample size of wētā radiotracked in gorse and providing an estimate of survival rates and movement patterns in spring.

\subsubsection{Radiotracking}

Wētā were located every 24 - 48 hours during the day (day-fix) using a TR-4 160/164 MHz Telonics receiver and Gamma Folding Yagi Antenna. Summer (December 2016 - January 2017) and spring (September - October 2018) radiotracking were conducted over three-week periods. Autumn (April - May 2018) radiotracking was extended to six weeks. GPS location (Garmin 60 Global Positioning System), visual status (seen or unseen), survival status (alive or predated), vegetation characteristics (species, height, structure, and percentage cover within a $1 \mathrm{~m}$ radius; see Appendix 3.4 for detail), and refuge characteristics (height and location within vegetation) were recorded at every day-fix. While the location of each wētā was determined at every day-fix, animals were not always seen in an attempt to reduce 
disturbance or because of their refuge height $(>2 \mathrm{~m})$. However, wētā were assumed to be alive if they had moved from their previous refuge.

Transmitters were removed from all wētā at the end of each radiotracking period by carefully cutting through the silicone sealant, leaving the aluminium saddle on the wētā. The aluminium saddle was coloured with a black permanent marker to reduce its visibility before release. Transmitters were removed and replaced after three weeks for all autumn wētā to allow radiotracking to continue for a further three weeks.

\subsubsection{Replacement of wētā}

If a transmitter was dropped, an individual died of natural causes (found dead, unknown cause), was predated, or lost due to transmitter malfunction within the first half of the study, it was replaced by another adult MGW of the same sex. Replacement of wētā translocated into native vegetation in autumn was stopped three weeks into the radiotracking period due to ethical concerns regarding high predation rates.

\subsubsection{Climate data}

Daily temperature data was sourced from NIWA's online Climate Database (Cliflo). To calculate average daily temperature, we averaged hourly temperature measurements from the 24 hours between day-fixes. The closest weather station to the MGWSR was Te Kuiti EWS (35km's NE; $38^{\circ} 20^{\prime} \mathrm{S} 175^{\circ} 09^{\prime} \mathrm{E}, 61 \mathrm{~m}$ elevation). Daily precipitation data was sourced from a nearby Mahoenui resident $(0.8 \mathrm{~km}$ 's $\mathrm{S})$.

\subsubsection{Data analysis}

A correlation analysis (Spearman's correlation coefficient) was used to determine whether there was a connection between transmitter to wētā body weight percentage and average distance moved. A strong correlation was identified if $r$ (Rho) was found to be more than 0.60 . A survival analysis was preformed using the Kaplan-Meier survival estimate to determine summer, autumn, and spring survival rates, in terms of predation of wētā, in gorse and native 
habitats (Kaplan \& Meier, 1958). Not all wētā experienced the event (predation) during radiotracking periods. Some wētā were lost during radiotracking periods due to causes other than predation (died of natural causes, dropped transmitter, or lost due to transmitter malfunction) resulting in a proportion of the sample having unknown survival probabilities (Clark et al., 2003). This issue is dealt with by right-censoring, whereby these wētā are included in the survival probability up until the point in time where they were lost (Clark et al., 2003). Wētā that were lost due to non-predation causes or did not experience the predation event within the study timeframe were also right-censured as their survival time until predation was unknown beyond the timeframe of the study (Clark et al., 2003). Censuring underestimates the true time until predation (Clark et al., 2003), but allows wētā that were not predated to be included in the analysis. A log-rank test was used to test for significance in survival rates between habitats. A Cox hazard regression model, which assesses the likelihood of an individual experiencing the hazard event (predation) at a specific point in time (Bradburn et al., 2003), was additionally used to test the influence of covariates habitat, sex, and possible translocation effect (original vs translocated gorse) on the probability of a wētā being preyed upon.

Average distance between consecutive day-fixes, net displacement over two weeks, total distance, and maximum distance were calculated using GPS coordinates and in-field measurements. Spring data that were collected every 24-hours were edited to a 48-hour interval so that average distance moved per unit of time could be compared between seasons. A generalised linear mixed-effects regression model with Gaussian distribution was used to test the effect of season, habitat and sex on average distance moved. As repeated measures were taken of individual wētā, the variable 'wētā' was specified as a random effect. A linear regression model was used to test the effect of season, habitat and sex on net displacement. Data from wētā released into original and translocated gorse habitat were grouped for net displacement analysis as there were too few observations to maintain the separate categories, and there was no indication that movement parameters varied between these two groups.

To assess movement patterns, diffusion coefficients (D) for individual wētā were calculated by modelling log displacement against log time using a linear regression model. Displacement was calculated using a moving window for progressively increasing time intervals (i.e. two day 
difference in autumn (48hr day-fixes) measured from day-fix one to day-fix two displacement, day-fix two to day-fix three displacement etc.) and averaged using root-mean square (RMS; Viswanathan et al., 2011). The model output provided D in the form of the beta coefficients (slope of the regression line). Diffusion coefficient means and 95\% confidence intervals were calculated grouped by the variables; season, habitat, sex, and interactions. Movement patterns are defined by three main categories: sub-diffusion $(0<D<0.5)$, random diffusion $(D=0.5)$ and super-diffusion ( $D>0.5)$. Random diffusion (known as a random walk) infers that animals are moving in a random, but exponential pattern, away from where they started (Tilles \& Petrovskii, 2016). Sub-diffusion is where a sublinear pattern is seen and animal movement is 'looping' or 'reversing' back to a particular area which could represent a home range (Hapca et al., 2007; Viswanathan et al., 2011). Super-diffusion (known as levy flight) is a super-linear pattern which infers animals are making small clustered steps amongst few larger steps and overall moving away from their start point faster than would be expected by random diffusion (Weeks \& Swinney, 1998). Super-diffusive movement has been interpreted as an optimal search strategy animals may use to find food, ideal habitat, or a mate (Reynolds, 2013). To determine if wētā movement was significantly different from random diffusion, we assessed whether $95 \%$ confidence intervals of the mean D's included 0.5 . We further assessed movement patterns by running a linear regression model of the diffusion coefficient with explanatory variables season, habitat and sex.

A linear regression model was used to compare the effect of average daily temperature $\left({ }^{\circ} \mathrm{C}\right)$ and daily precipitation $(\mathrm{mm})$ on average distance moved between consecutive refuges by male and female MGW. This was done for spring data only as summer and autumn day-fixes were taken every $48 \mathrm{hrs}$. Both average daily temperature and average daily distance moved were log-transformed to satisfy model assumptions.

To assess MGW diurnal refuge use in the MGWSR, a range of statistical models were used to analyse data collected during radiotracking. Firstly, a generalised linear mixed-effects model with Binomial distribution was used to model the effects of season, habitat, and sex on wētā observation during day-fixes (visually located versus not seen). Secondly, a generalised linear mixed-effects model with Gaussian distribution was used to model the effects of season, habitat, and sex on wētā diurnal refuge selection in terms of height in vegetation and gorse cover. Thirdly, a generalised linear mixed-effects model with Binomial distribution was used 
to assess the effects of season and sex on wētā diurnal refuge selection in terms of gorse browse (unbrowsed vs semi-browsed). The browsed category was excluded from analysis due to too few observations of wētā in heavily browsed gorse bushes.

As repeated measures were taken from individual wētā during radiotracking, the variable 'wētā' was defined as a random effect in all generalised linear mixed-effects models. Only observations where wētā were visually located were used to model diurnal refuge selection in gorse habitat, whereas all data were used to estimate native habitat diurnal refuge use due to the low number of visual observations.

All statistical analysis was completed in R version 3.5.1 (R Core Team, 2018) using packages survival (Therneau, 2015), and survminer (Kassambara \& Kosinski, 2018) for survival analysis and Ime4 (Bates et al., 2015), ImerTest (Kuznetsova et al., 2017), and emmeans (Lenth, 2018) for movement and diurnal refuge use analysis. $P$-values were considered significant when $\alpha<0.05$ (95\% confidence).

\subsection{Results}

\subsubsection{Transmitter use on MGW}

No correlation was found between the ratio of transmitter weight to wētā body weight and average distance moved between day-fixes (rho=-0.22, $p=0.132$ ), suggesting transmitters used in this study had little or no effect on wētā activity.

\subsubsection{Survival}

Survival rates differed greatly between radiotracking periods whereby all predation events occurred in autumn (Table 3.1). The survival outcome for all wētā during the three radiotracking periods is summarised in Appendix 3.5. No wētā were preyed upon in the summer $(n=14)$, regardless of habitat (Table 3.1$)$. The survival probability (with respect to predation) in summer was therefore 1.0 for wētā in all three release categories. Three wētā 
(one female and two males) died of natural causes during the three weeks of radiotracking (Appendix 3.6).

During the autumn radiotracking period $(n=31) 15$ predation events occurred. Most mortality (80\%) occurred in the native habitat (Table 3.1). After 40 days of radiotracking, wētā in original and translocated gorse habitat were seven times more likely to be alive than those released into native vegetation. This difference was found to be highly significant ( $p=0.001 ;$ Fig. 3.1). A Cox hazard regression analysis confirmed the significant effect of habitat on the likelihood of survival $(Z=2.83, p=0.005)$ and estimated wētā in the native habitat were approximately nine times more likely to be predated at any one moment in time than those in the gorse (Table 3.2). Sex and potential translocation effect did not significantly influence survival rates $(Z=0.18, p=0.86 ; Z=0.60, p=0.55 ;$ Table 3.2). Only two wētā released into the native habitat (one male and one female) survived and had transmitters removed at the end of the radiotracking period. Two female wētā (one in native vegetation and one in gorse) died of natural causes during this six-week period (Appendix 3.6).

Table 3.1 Summary of release categories, radiotracking seasons (year in parentheses), sample sizes ( $n=$ number of individuals), and tracking duration for MGW radiotracking. The number of wētā predated are given in parentheses following sample size.

\begin{tabular}{lcccc}
\hline Season (Year) & $\begin{array}{c}\text { Original site of } \\
\text { capture in gorse } \\
\text { habitat }\end{array}$ & $\begin{array}{c}\text { Translocated into } \\
\text { unfamiliar gorse } \\
\text { habitat }\end{array}$ & $\begin{array}{c}\text { Translocated } \\
\text { into unfamiliar } \\
\text { native habitat }\end{array}$ & $\begin{array}{c}\text { Tracking } \\
\text { duration }\end{array}$ \\
\hline Summer (Dec 16- Jan 17) & $\mathrm{n}=6(0)$ & $\mathrm{n}=4(0)$ & $\mathrm{n}=4(0)$ & 3 weeks \\
Autumn (Apr-May 18) & $\mathrm{n}=5(1)$ & $\mathrm{n}=7(2)$ & $\mathrm{n}=19(12)$ & 6 weeks \\
Spring (Oct - Nov 18) & $\mathrm{n}=5(0)$ & $\mathrm{n}=5(0)$ & $\mathrm{NA}$ & 3 weeks \\
\hline
\end{tabular}

No wētā were translocated into the native habitat during spring due to ethical concerns regarding the high predation rate observed in autumn. However, adult MGW were radiotracked in both gorse categories to assist in detecting seasonal differences in movement 
and survival rates $(n=10)$. No predations were recorded (Table 3.1) and no wētā died of natural causes resulting in a survival rate of 1.0 for both gorse categories in spring.

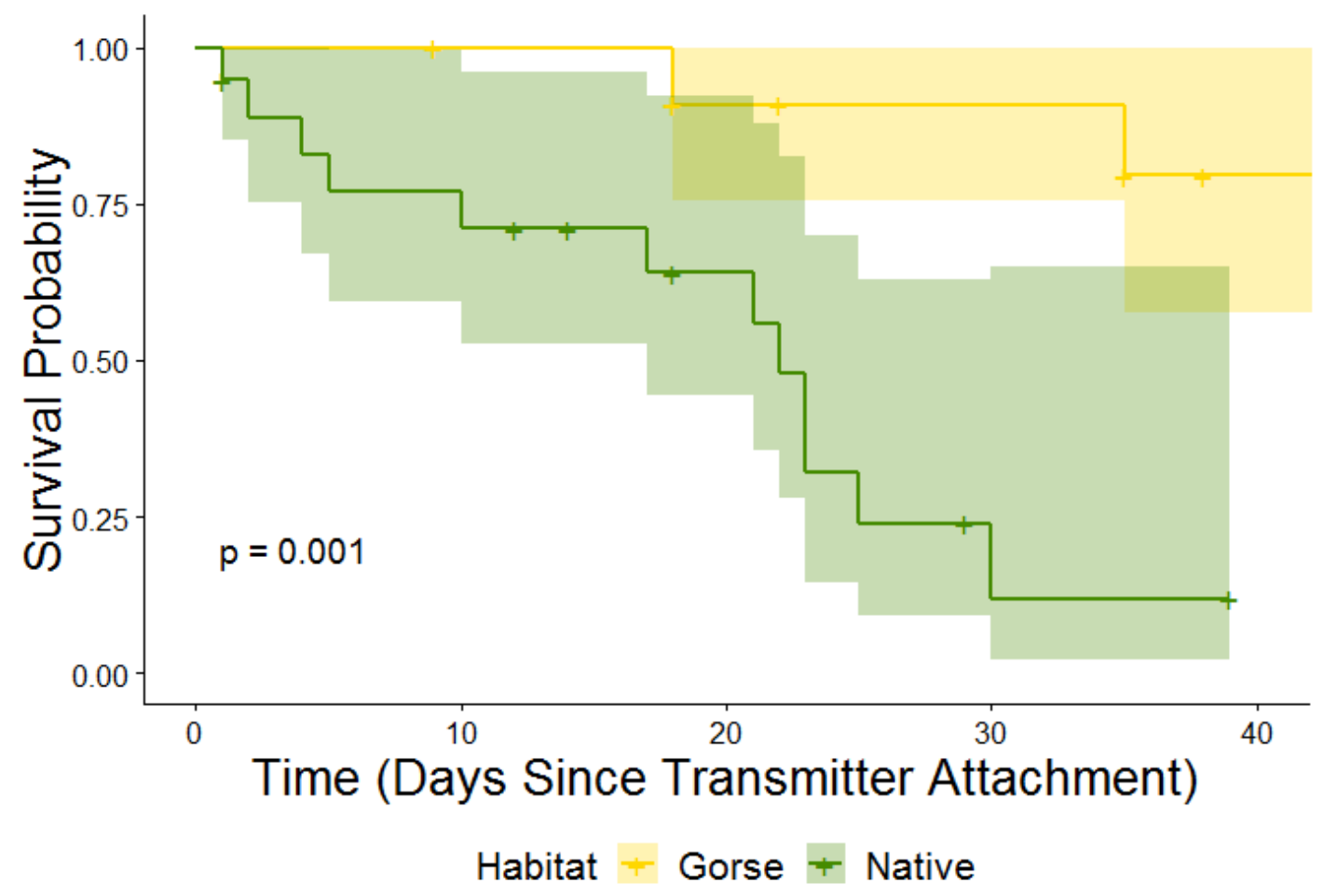

Figure 3.1 Survival probability of MGW in gorse (yellow) and native vegetation (green) habitats for the autumn 2018 radiotracking period. Shaded areas represent corresponding $95 \%$ confidence intervals for survival curves. Plus (+) symbols represent right-censored data. The $p$-value $(p)$ indicates a significant difference $(p<0.05)$ between survival probabilities in gorse and native habitats.

Table 3.2 Summary of Cox hazard regression results from univariate models. Reference levels for each variable are provided in parentheses Beta values (B) for coefficients are displayed with standard errors (SE). Asterisks $\left({ }^{* *}\right)$ indicate statistically significant $p$-value. Exponentiated Beta coefficients $(\operatorname{Exp}(B))$ provide an estimate of the variable's proportional effect on predation occurring.

\begin{tabular}{lcccc}
\hline Variable & $\mathbf{B}(\mathbf{S E})$ & Wald Statistic (z) & p-value & Exp(B) \\
\hline Habitat (Gorse) & $2.26(0.80)$ & 2.83 & $0.005^{* *}$ & 9.59 \\
Sex (Female) & $0.09(0.52)$ & 0.18 & 0.860 & 1.10 \\
Translocation effect (Original Gorse) & $0.78(1.32)$ & 0.60 & 0.552 & 2.19 \\
\hline
\end{tabular}




\subsubsection{Movement patterns of MGW}

The number of day's tracked, total distance, net displacement over two-weeks, average distance in 48 hours, and maximum distance moved within 48 hours during the radiotracking study is summarised for all wētā in Appendix 3.5. Average distances moved by MGW varied between seasons. Wētā radiotracked in autumn moved significantly less over 48 hours compared to those radiotracked in summer $(\mathrm{t}=6.57, p<0.001)$ and spring $(\mathrm{t}=4.38, p<0.001)$, regardless of habitat and wētā sex (Fig. 3.2, Table 3.3). Wētā moved on average $2.58 \mathrm{~m}$ per 48 hours in autumn compared to $11.68 \mathrm{~m}$ and $7.59 \mathrm{~m}$ in summer and spring respectively.

Net displacement over two weeks differed largely between seasons (Fig. 3.3, Table 3.4). Wētā radiotracked in autumn were found to have only moved on average $6.84 \mathrm{~m}$ from their release site over a period of two weeks. Whereas, wētā radiotracked during summer $(t=-4.73$, $p<0.001)$ and spring $(\mathrm{t}=-3.20, p=0.008)$ moved on average $36.19 \mathrm{~m}$ and $24.67 \mathrm{~m}$ over a period of two weeks, respectively. Average net displacement in spring and summer were not significantly different $(t=-0.985, p=0.591)$. Habitat and sex did not significantly influence net displacement of wētā in summer (habitat $t=0.124, p=0.905$; sex $t=0.318, p=0.759$ ), autumn (habitat $\mathrm{t}=-0.752, p=0.462$; sex $\mathrm{t}=-2.023, p=0.058$ ), or spring (sex $\mathrm{t}=1.507, p=0.176$ ). However, male wētā generally moved further over the two-week period than females in all seasons.

Analysis of movement patterns (diffusion) revealed most wētā exhibited movement consistent with random diffusion (Fig. 3.4, Table 3.5). However, sub-diffusion (Fig. 3.6 \& 3.7) and super-diffusion were exhibited by male wētā in native habitat during autumn and a single female wētā in native habitat during summer, respectively. Despite wētā in autumn, regardless of sex and habitat, having movement patterns consistent with sub-diffusion compared to random-diffusion in summer and spring, no significant differences were found between seasons (summer $\mathrm{t}=0.651, p=0.518$; spring $\mathrm{t}=1.451, p=0.154$; Fig. 3.5, Table 3.5). Wētā in gorse and native habitats, regardless of season and sex, were found to have significantly different average diffusion coefficients ( $\mathrm{t}=-2.047, p=0.0467$; Fig. 3.5, Table 3.5). Average wētā movement in gorse was found to be consistent with random-diffusion whilst movement of wētā in native habitat was consistent with sub-diffusion. Wētā sex did not influence movement patterns with both sexes, regardless of season and habitat, following random-diffusion ( $\mathrm{t}=-0.759, p=0.452)$. 
Table 3.3 Summary of average distances $(\mathrm{m})$ moved by MGW over 48 hours in summer, autumn and spring. Sample sizes are given in parentheses.

\begin{tabular}{|c|c|c|c|c|c|c|c|}
\hline \multirow[b]{2}{*}{ Habitat } & \multirow[b]{2}{*}{ Sex } & \multicolumn{2}{|c|}{ Summer (16/17) } & \multicolumn{2}{|c|}{ Autumn (18) } & \multicolumn{2}{|c|}{ Spring (18) } \\
\hline & & Mean & $95 \% \mathrm{Cl}$ & Mean & $95 \% \mathrm{Cl}$ & Mean & $95 \% \mathrm{Cl}$ \\
\hline \multirow{2}{*}{ Original gorse } & Male & $11.49(22)$ & $6.02-16.96$ & $5.11(28)$ & $0.53-9.69$ & $9.19(21)$ & $6.00-12.37$ \\
\hline & Female & $9.14(30)$ & $4.99-13.29$ & $1.57(56)$ & $0.74-2.40$ & $7.78(18)$ & $4.91-10.65$ \\
\hline \multirow{2}{*}{ Translocated gorse } & Male & $6.37(15)$ & $3.34-9.39$ & $4.46(79)$ & $2.34-6.58$ & $7.73(21)$ & $4.24-11.21$ \\
\hline & Female & $10.12(17)$ & $4.85-15.39$ & $4.55(48)$ & $2.48-6.62$ & $5.95(32)$ & $4.18-7.72$ \\
\hline \multirow{2}{*}{ Native } & Male & $20.33(30)$ & $12.24-28.42$ & $1.19(80)$ & $0.58-1.81$ & NA & NA \\
\hline & Female & $5.00(11)$ & $1.70-8.30$ & $1.00(51)$ & $0.48-1.51$ & NA & NA \\
\hline Grand Means & & 10.41 & $6.07-14.74$ & 2.98 & $1.45-4.51$ & 7.66 & $6.60-8.72$ \\
\hline
\end{tabular}

Table 3.4 Summary of average net displacement $(\mathrm{m})$ over two weeks by MGW. Sample sizes are given in parentheses.

\begin{tabular}{|c|c|c|c|c|c|c|c|}
\hline \multirow[b]{2}{*}{ Habitat } & \multirow[b]{2}{*}{ Sex } & \multicolumn{2}{|c|}{ Summer (16/17) } & \multicolumn{2}{|c|}{ Autumn (18) } & \multicolumn{2}{|c|}{ Spring (18) } \\
\hline & & Mean (n) & $95 \% \mathrm{Cl}$ & Mean (n) & $95 \% \mathrm{Cl}$ & Mean (n) & $95 \% \mathrm{Cl}$ \\
\hline Gorse (Original & Male & $39.90(4)$ & $9.02-70.78$ & $4.32(5)$ & $0.36-8.28$ & $30.43(4)$ & $23.60-37.27$ \\
\hline \& Translocated) & Female & $26.50(5)$ & $9.45-43.55$ & $12.19(6)$ & $6.86-17.53$ & $18.90(5)$ & $2.49-35.30$ \\
\hline \multirow{2}{*}{ Native } & Male & $53.28(2)$ & $-12.10-118.65$ & $6.14(6)$ & $-0.44-12.72$ & NA & NA \\
\hline & Female & $25.08(1)$ & NA & $4.73(4)$ & $2.62-6.84$ & NA & NA \\
\hline Grand Means & & 36.19 & $23.25-49.13$ & 6.84 & $3.27-10.42$ & 24.67 & $13.36-35.97$ \\
\hline
\end{tabular}

Table 3.5 Summary of average diffusion parameter (D) of MGW in summer, autumn and spring. Sample sizes are given in parentheses. Asterisk $\left({ }^{*}\right)$ indicates non-random movement, either sub-diffusive $(D<0.5)$, or super-diffusive $(D>0.5)$.

\begin{tabular}{|c|c|c|c|c|c|c|c|}
\hline \multirow[b]{2}{*}{ Habitat } & \multirow[b]{2}{*}{ Sex } & \multicolumn{2}{|c|}{ Summer (16/17) } & \multicolumn{2}{|c|}{ Autumn (18) } & \multicolumn{2}{|c|}{ Spring (18) } \\
\hline & & Mean & $95 \% \mathrm{Cl}$ & Mean & $95 \% \mathrm{Cl}$ & Mean & $95 \% \mathrm{Cl}$ \\
\hline \multirow{2}{*}{ Gorse } & Male & $0.69(5)$ & $0.11-1.27$ & $0.47(6)$ & $0.35-0.59$ & $0.65(4)$ & $0.41-0.88$ \\
\hline & Female & $0.44(5)$ & $0.10-0.78$ & $0.51(6)$ & $0.35-0.68$ & $0.61(5)$ & $0.23-0.99$ \\
\hline \multirow{2}{*}{ Native } & Male & $0.29(3)$ & $0.06-0.52$ & $0.20 *(7)$ & $-0.02-0.43$ & NA & NA \\
\hline & Female & $0.72 *(1)$ & NA & $0.40(4)$ & $0.29-0.52$ & NA & NA \\
\hline Grand means & & 0.52 & $0.27-0.76$ & 0.40 & $0.29-0.49$ & 0.63 & $0.40-0.85$ \\
\hline
\end{tabular}



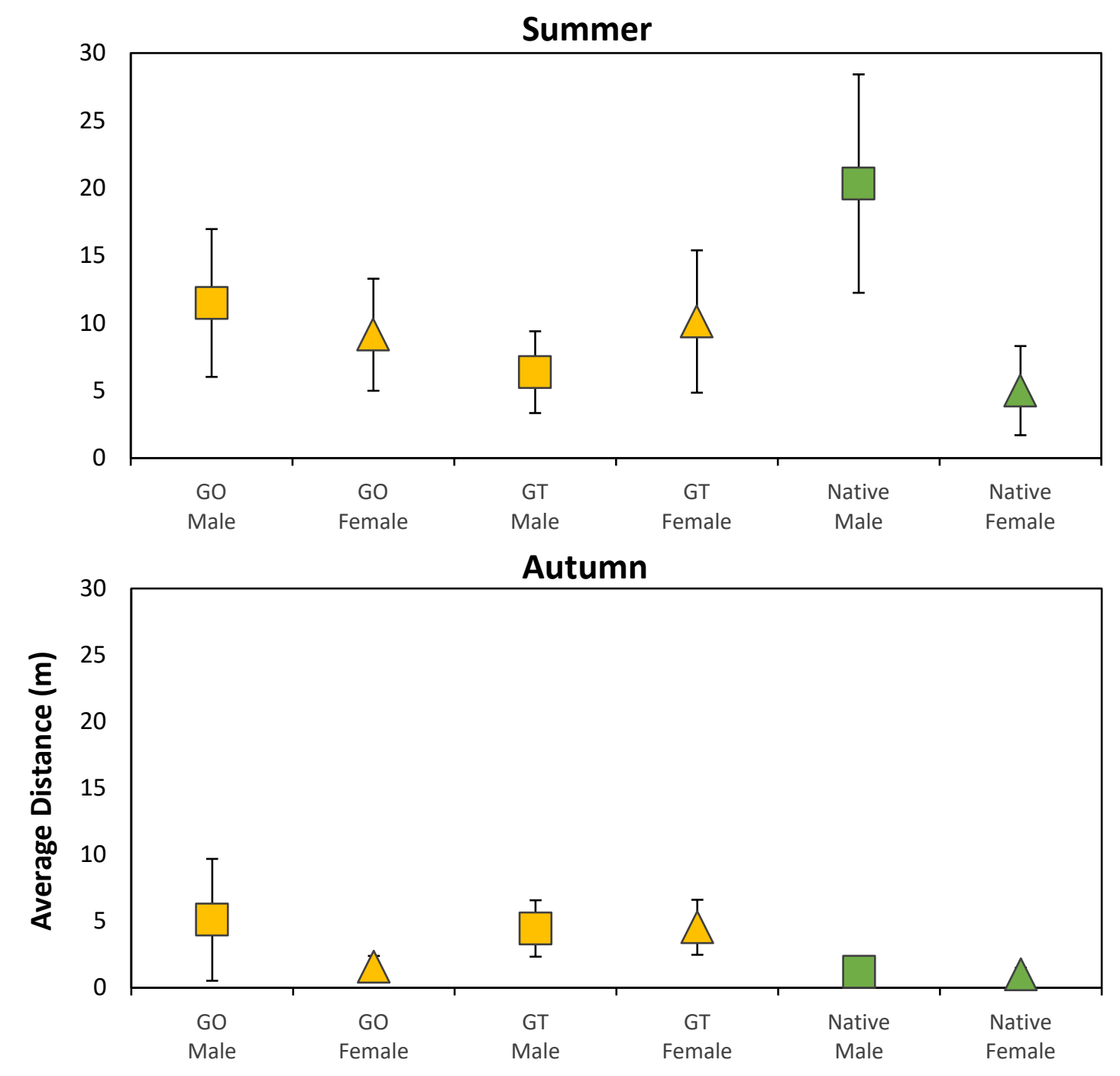

Spring

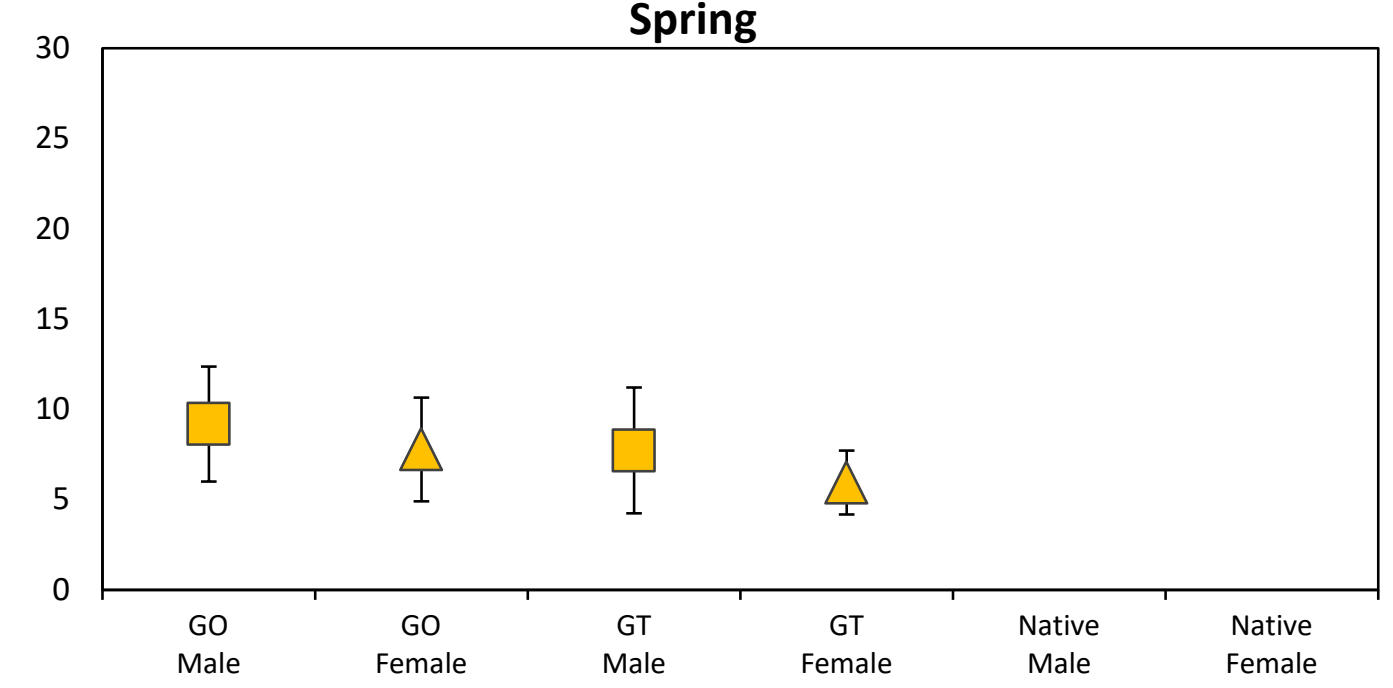

Figure 3.2 Average distance $(\mathrm{m})$ moved by female (triangles) and male (squares) MGW over 48 hours in summer, autumn, and spring in gorse (yellow) and native (green) habitats. GO refers to original gorse habitat and GT refers to translocated gorse habitat. Error bars are corresponding $95 \%$ confidence intervals. 

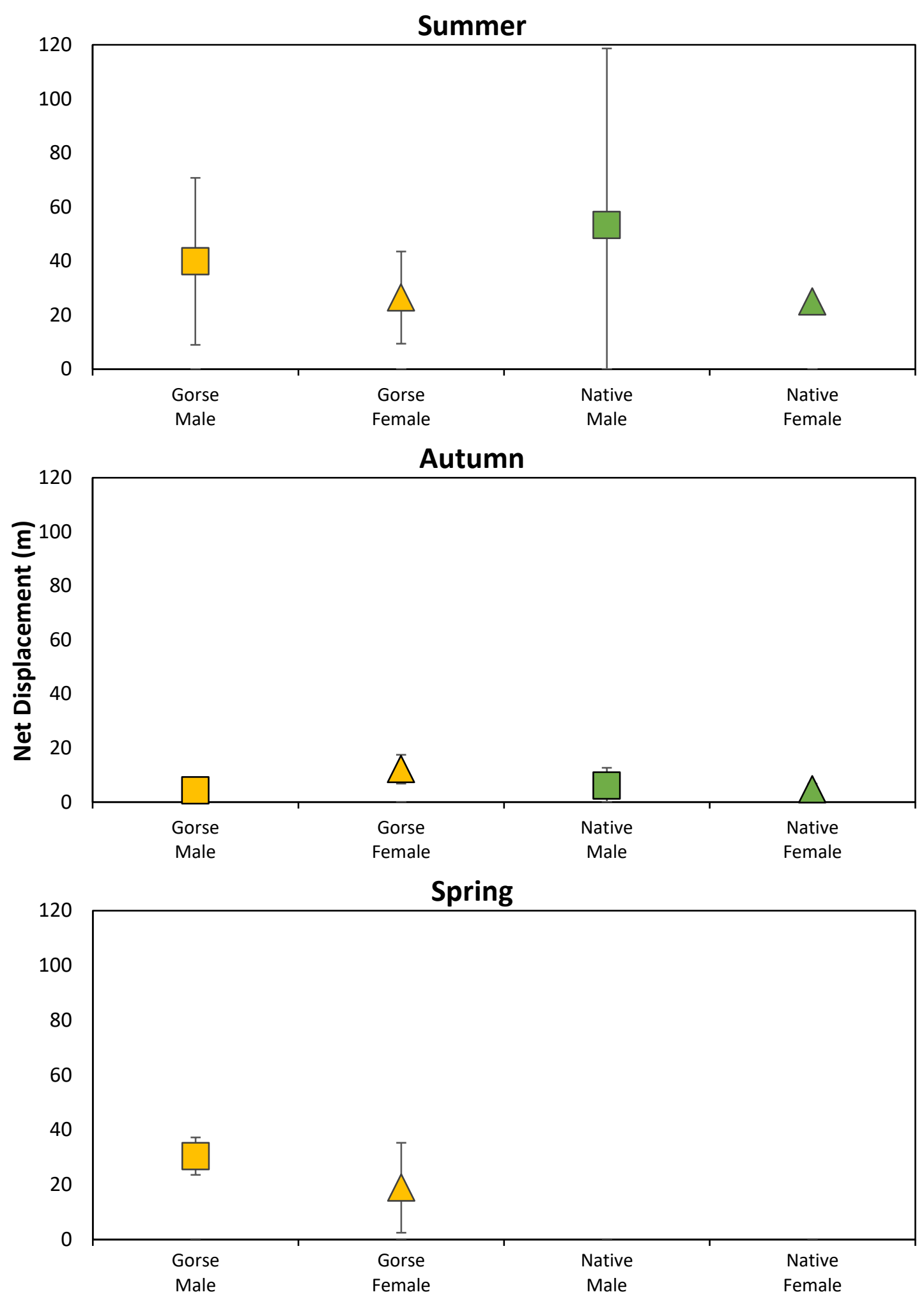

Figure 3.3 Net displacement $(\mathrm{m})$ moved by female (triangles) and male (squares) MGW over two weeks in summer, autumn, and spring in gorse (yellow) and native (green) habitats. Error bars are corresponding 95\% confidence intervals. 


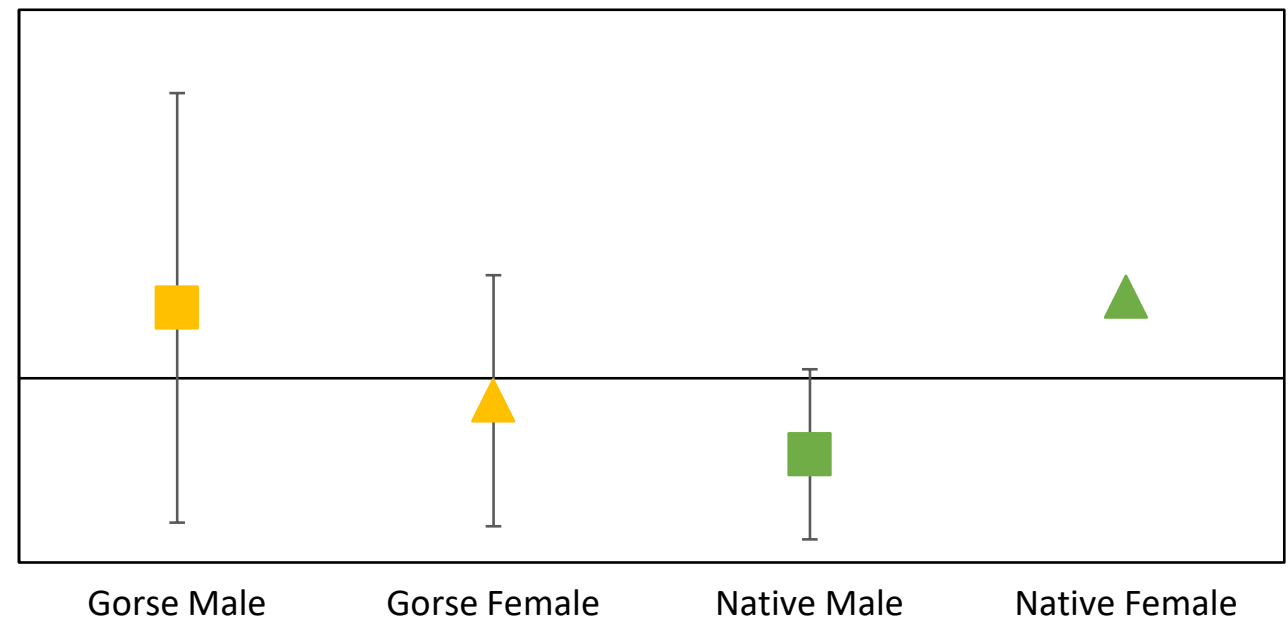

Autumn

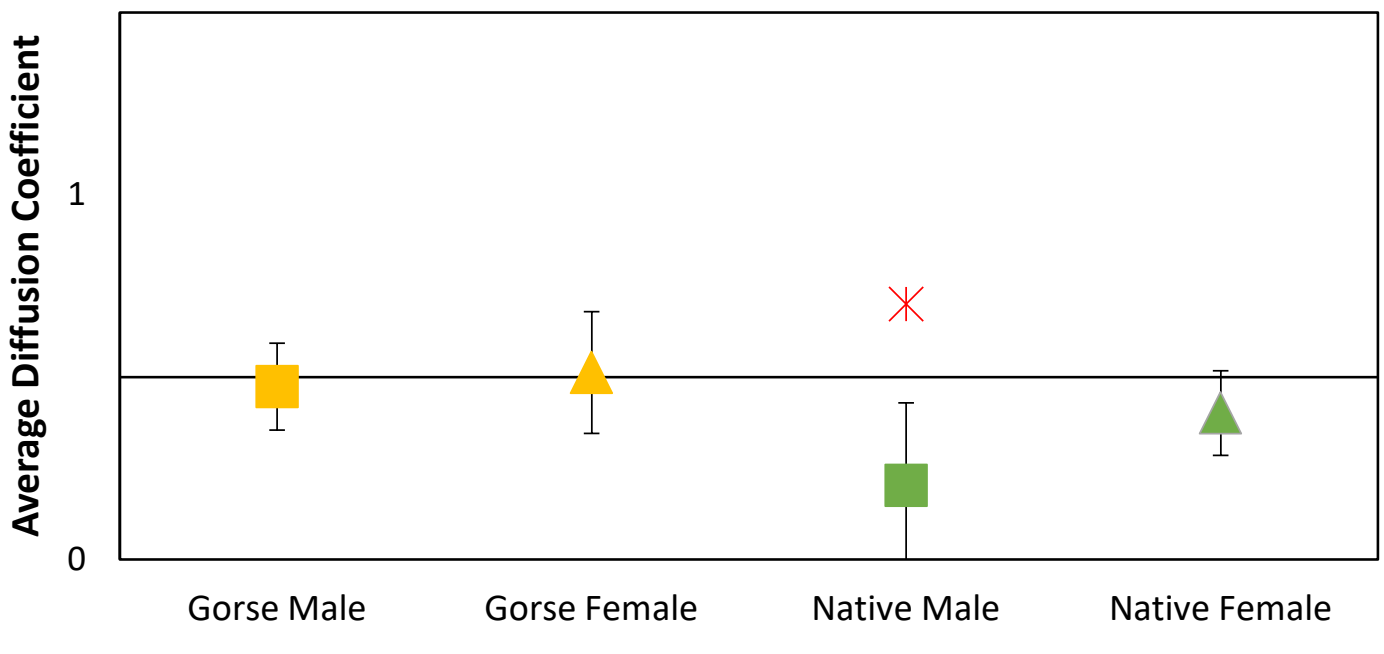

Spring

1

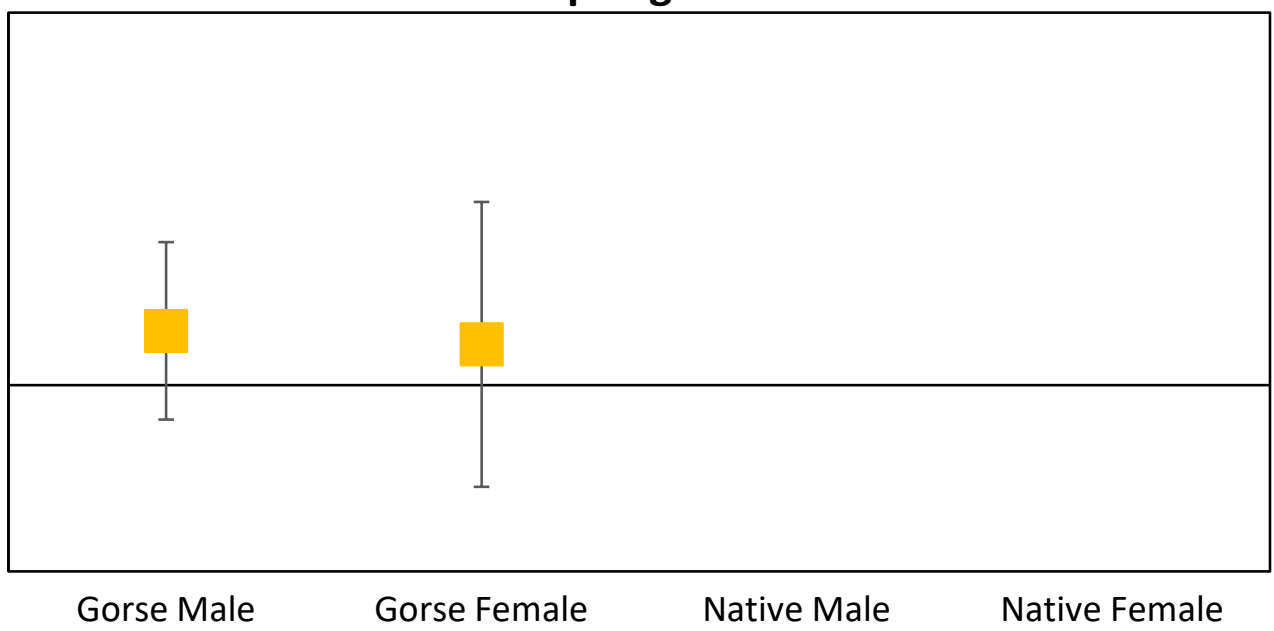

Figure 3.4 Average diffusion coefficients (D) for male (squares) and female (triangles) MGW in gorse (yellow) and native vegetation (green) habitats in summer, autumn, and spring. Diffusion can be defined as random diffusion $(D=0.5)$, sub-diffusion $(0<D<0.5)$, or superdiffusion $(D>0.5)$. Error bars are corresponding 95\% confidence intervals. Asterisk $\left({ }^{*}\right)$ indicates average diffusion coefficient significantly different from random-diffusion $(95 \%$ confidence interval does not include 0.5). 

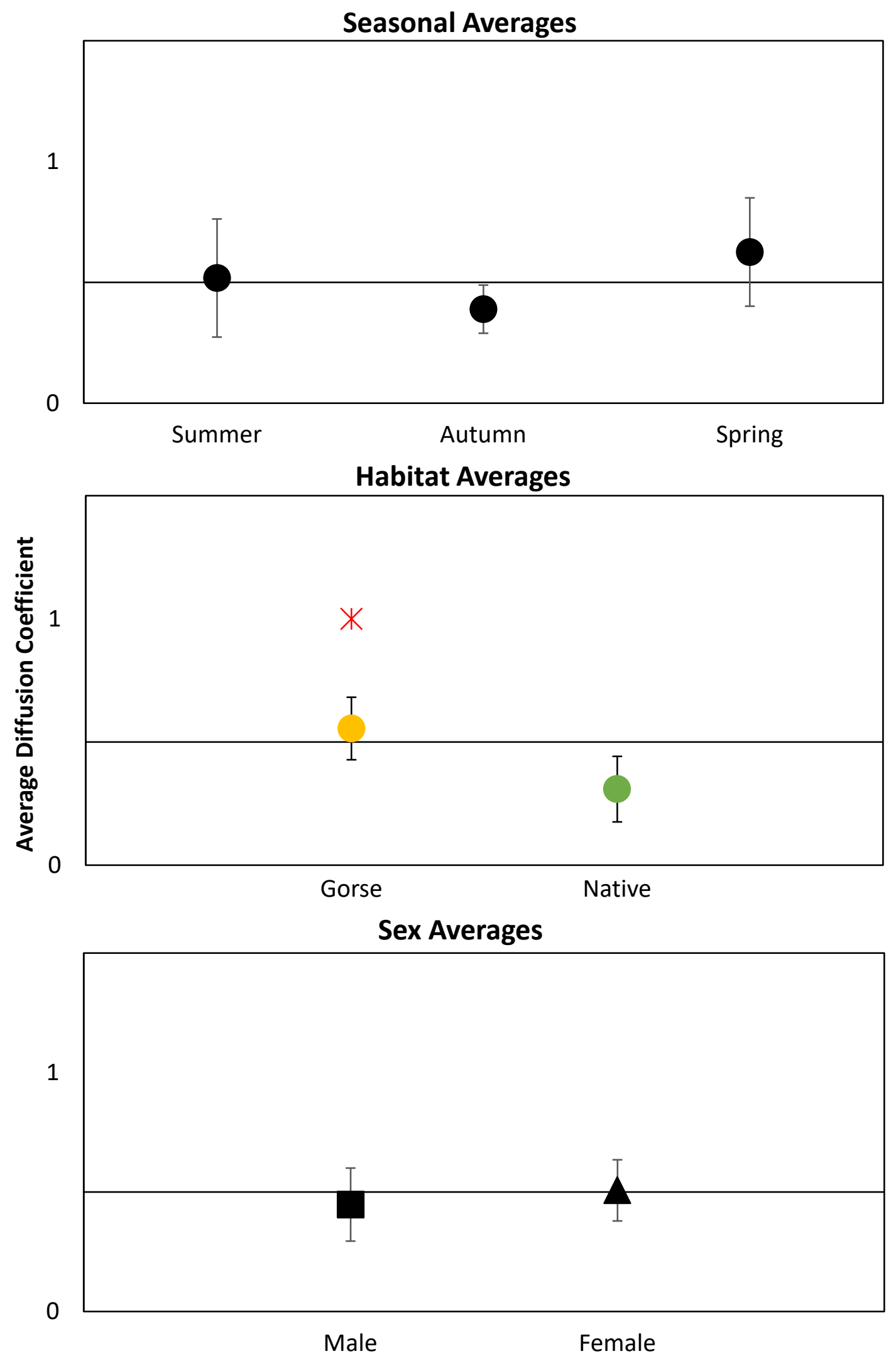

Figure 3.5 Average diffusion coefficients (D) for MGW by season, habitat, and sex. Gorse and native habitats are represented by yellow and green symbols, respectively. Male and female wētā are represented by square and triangle symbols, respectively. Diffusion can be defined as random diffusion ( $D=0.5)$, sub-diffusion $(0<D<0.5)$, or super-diffusion $(D>0.5)$. Error bars are corresponding $95 \%$ confidence intervals. Asterisk $(*)$ indicates significant difference between average diffusion coefficients $(p \leq 5)$. 


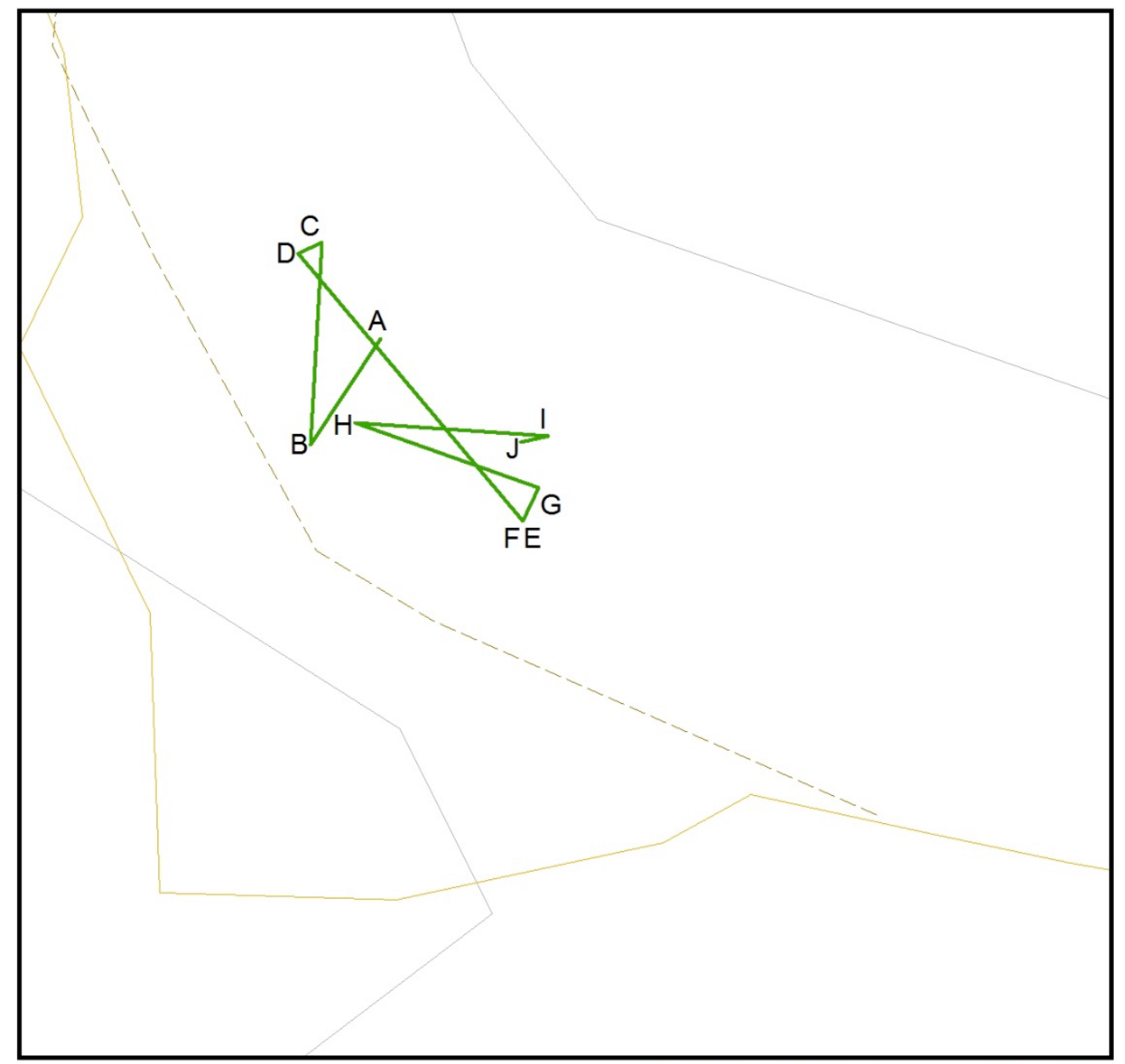

— Female 50.2 Original Gorse

- MGWSR Outline

- - MGWSR Firebreaks
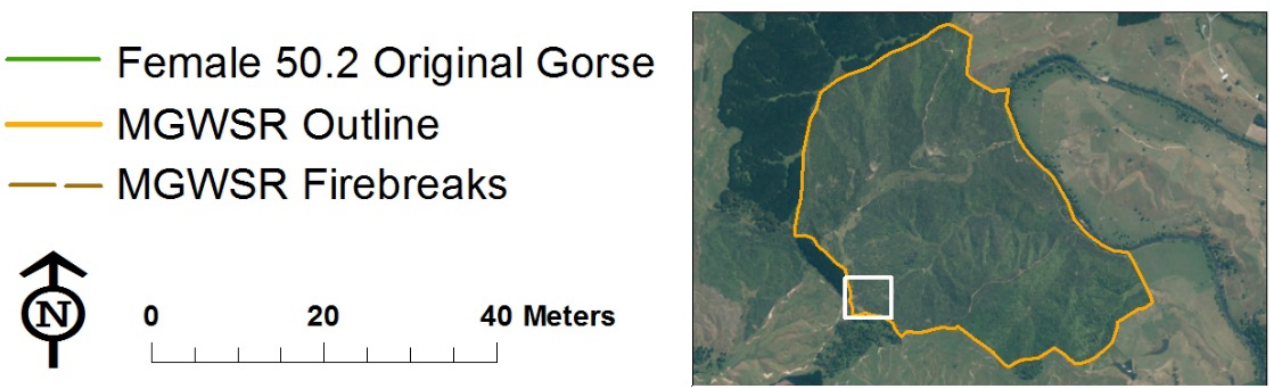

Figure 3.6 An example of wētā movement during radiotracking in summer. Wētā 50.2 moved a total of $132.7 \mathrm{~m}$ over 21 nights and displayed a looping movement pattern consistent with sub-diffusion $(D=0.003(-0.15-0.16))$. 


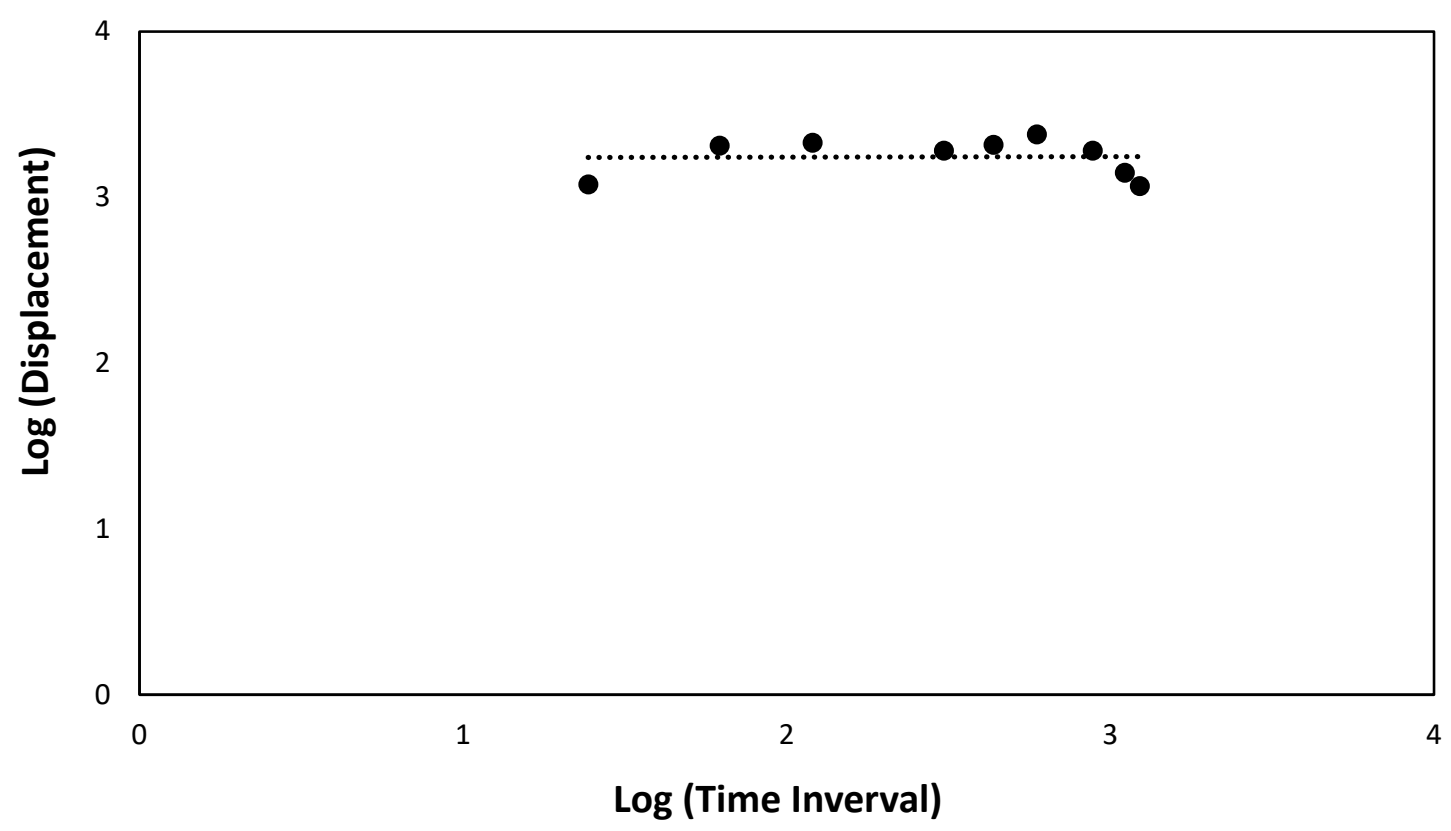

Figure 3.7 Example of moving window regression used to determine diffusion coefficients. Wētā 50.2 (summer) displayed a looping movement pattern consistent with sub-diffusion (D $=0.003(-0.15-0.16))$.

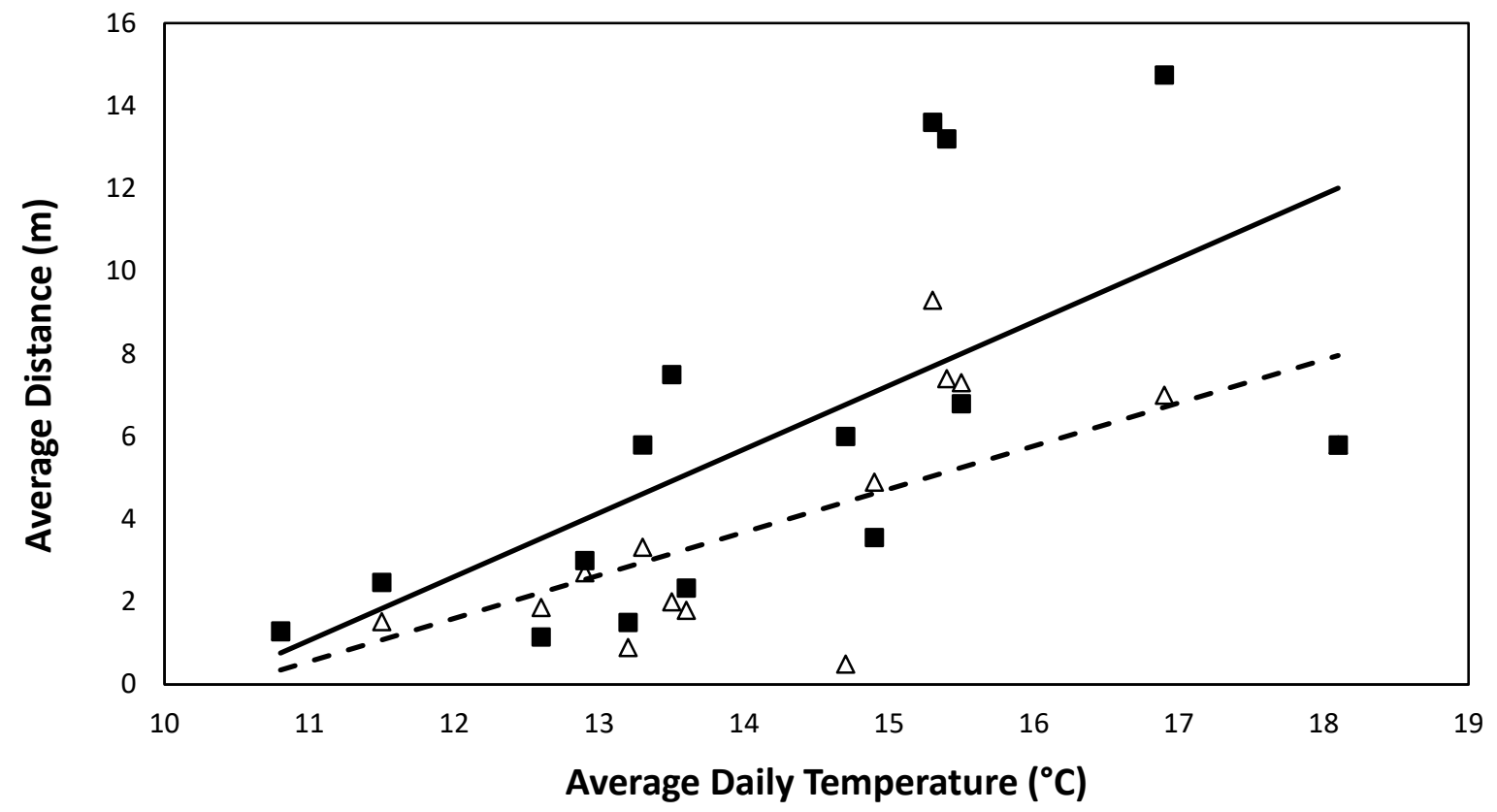

Figure 3.8 Average distance $(\mathrm{m})$ moved by male (squares and solid line) and female (triangles and dashed line) wētā in gorse habitat over 24 hours versus average daily temperature $\left({ }^{\circ} \mathrm{C}\right)$ in spring 2018. 
Average daily temperature had a significant influence on distance moved over $24 \mathrm{hrs}$ in spring. Both male and female wētā moved further on warmer days $\left(>13.5^{\circ} \mathrm{C}\right)$ compared to cooler days (male $\mathrm{t}=3.864, p=0.001$; female $\mathrm{t}=3.334, p=0.003$; Fig. 3.8). Male wētā general moved further when in warmer condition $(5-12 \mathrm{~m})$ compared to females $(3-8 \mathrm{~m})$. Daily precipitation had no effect on wētā movement (male: $\mathrm{t}=0.795, p=0.457$; female: $\mathrm{t}=0.764, p=0.474$ ).

\subsubsection{Wētā observations during radiotracking}

In gorse habitat, MGW were visually located on 78 of 84 day-fixes (93\%) in summer, 160 of 206 day-fixes (78\%) in autumn, and 136 of 162 day-fixes (84\%) in spring. Within seasons, male and female wētā were seen equally as often during day-fixes (summer 92\% and 94\%; autumn $80 \%$ and $76 \%$; spring $87 \%$ and $81 \%$ for male and female wētā, respectively). The proportion of wētā seen during radiotracking in autumn was found to be significantly less than the proportion observed in summer $(z=-2.666, p=0.008)$, regardless of sex. There was no significant difference between the proportion of wētā seen in autumn and spring $(z=-1.189$, $p=0.235)$, and summer and spring $(z=-1.788, p=0.174)$. In native vegetation habitat, MGW were visually located much less frequently at day-fixes compared to those in gorse habitat $(z=8.199, p<0.001)$. Wētā in native vegetation habitat were only seen on 11 of 41 day-fixes in summer (27\%) and 16 of 152 day-fixes in autumn (11\%). These proportions were not significantly different $(z=-1.607, p=0.108)$. Female wētā in native vegetation were seen more frequently in both summer (18\%) and autumn (14\%) compared to male wētā in native vegetation (summer 3\%; autumn $8 \%$ ). Season had no effect on the number of times MGW were visually located in both gorse and native vegetation habitats. $(z=0.47, p-0.963)$.

From day-fixes where MGW were seen, we assessed the proportion of times individuals were seen within $10 \mathrm{~cm}$ of another wētā (marked or unmarked). Wētā radiotracked in native vegetation habitat were never observed with other wētā ( $0 \%$ of 27 observations). Wētā radiotracked in gorse habitat were observed with other individuals on $10 \%$ of visually confirmed fixes in summer and $19 \%$ of visually confirmed fixes in spring. Summer and spring percentages were not significantly different $(z=0.977, p=0.592)$. No radiotracked wētā in gorse habitat were observed with other individuals during autumn. Males and females in both summer and spring were observed with individuals of the opposite sex in equal proportions 
$(z=-0.56, p=0.575)$. On only one occasion in summer, were two wētā of the same sex observed together (two male wētā) .Of radiotracked wētā that were recorded with another individual, copulation was observed most often in spring (46\% of 26 occasions) compared to summer (13\% of 8 occasions), however, this difference between seasons was not significant ( $z=-1.584$, $p=0.113)$.

\subsubsection{Diurnal refuge use in gorse and native vegetation}

The structure and average height of gorse is very different from that of native vegetation. Gorse is a woody shrub that averages $2.5 \mathrm{~m}( \pm 1 \mathrm{~m}$ IQR) in the MGWSR (Fig. 3.9). MGW generally take refuge among the spikey foliage, live or dead (93\% of 372-day-fixes). The native vegetation in the reserve's southernmost valley is dominated by tree ferns and mahoe. Kanuka, divaricating Coprosma spp., Muehlenbeckia vine and wild passion vines are also present in lesser quantities. In areas where MGW were radiotracked, native vegetation was on average 5.5m ( $\pm 1 \mathrm{~m}$ IQR; Fig. 3.9). Radiotracked wētā were observed less frequently in native vegetation (11\% of 152 -day-fixes) than in gorse habitat, but were found to take refuge in tree fern crowns, under tree fern skirts, on tree branches or among mahoe foliage or fern fronds.

The average height of an MGW's diurnal refuge within gorse was found to be significantly different from that in native vegetation ( $t=11.776, p<0.001$; Fig. 3.10). In gorse habitat, MGW were generally found in the mid-section of the bush at an average height of $1.5 \mathrm{~m}( \pm 0.88 \mathrm{~m}$ IQR), whereas in native vegetation, MGW were more frequently estimated to be near the top of tree ferns or in the mahoe canopy ( $4.0 \mathrm{~m} \pm 1.5 \mathrm{~m}$ IQR on average). 


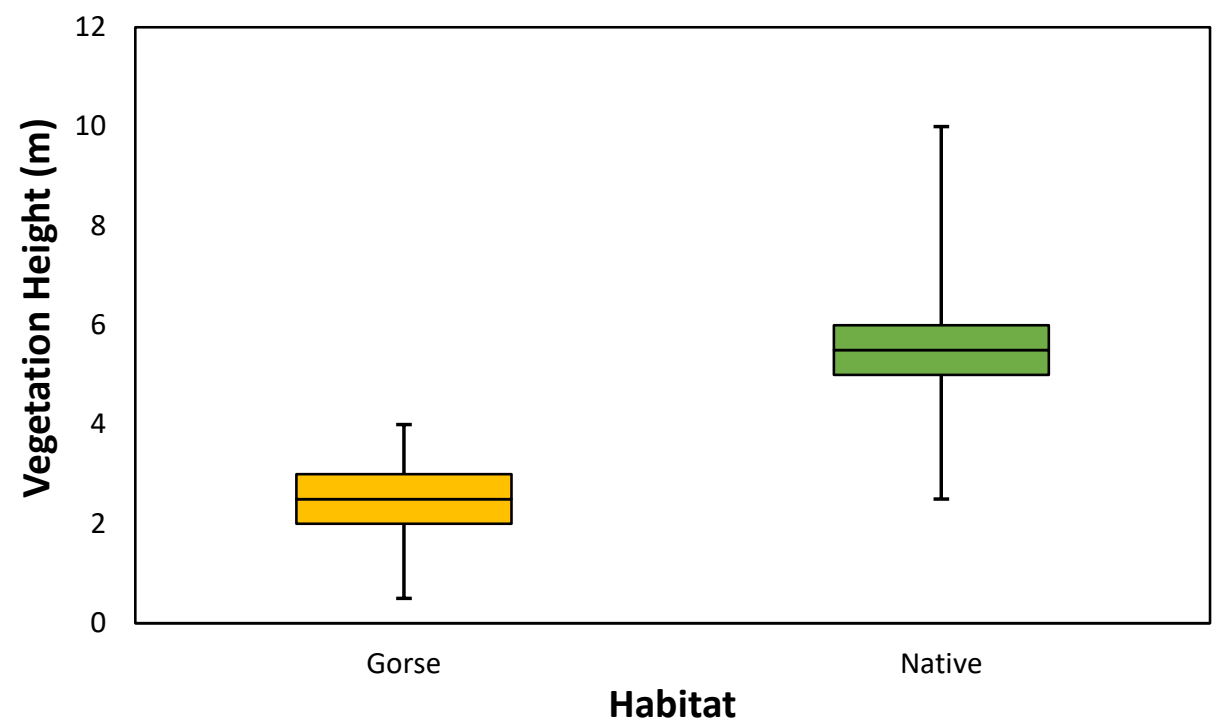

Figure 3.9 Height range $(m)$ of vegetation used by radiotracked MGW in gorse $(n=452$ observations) and native vegetation ( $n=192$ observations). Vegetation heights were taken at every day-fix, regardless of whether the wētā was visually located or not.

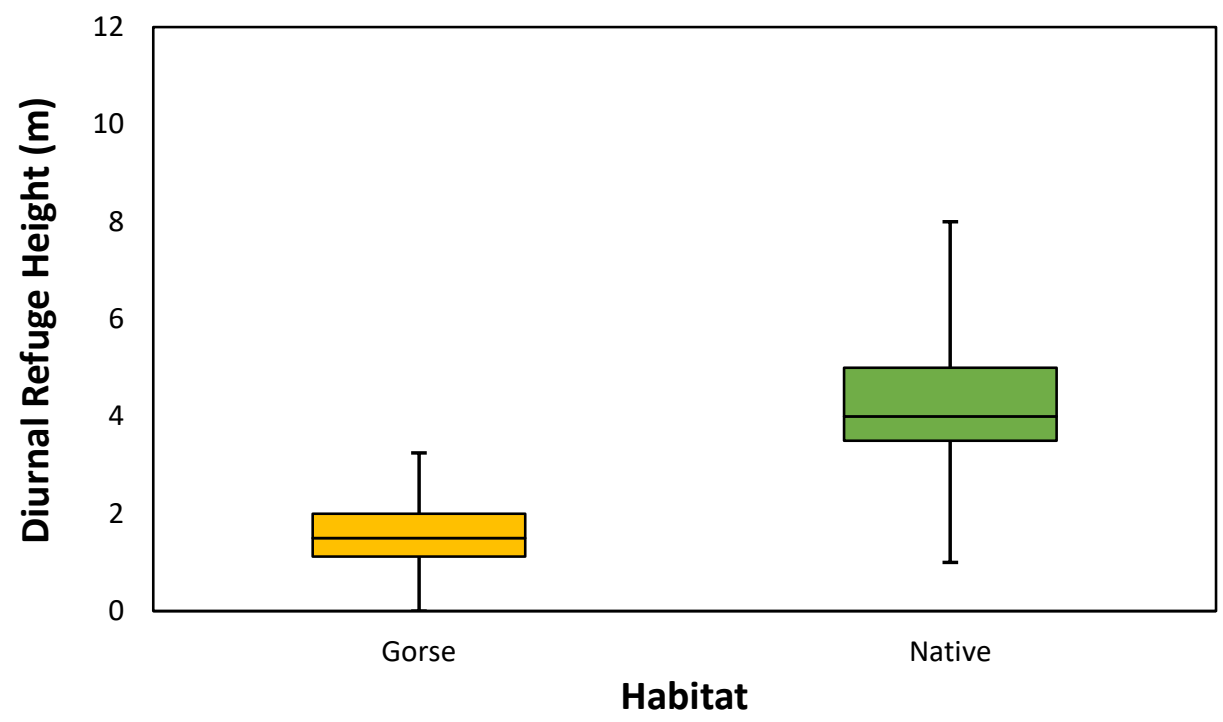

Figure 3.10 Height range $(m)$ of radiotracked MGW diurnal refuges within gorse $(n=378$ observations) and native vegetation ( $n=192$ observations). In gorse habitat, measures were taken from visually located wētā only. In native habitat, diurnal refuge heights were estimated based on transmitter signal and the height of the plant species the wētā was inhabiting, due to too few visual observations.

In terms of gorse foliage cover, MGW were generally found taking refuge in areas with denser gorse, covering an average of $80 \%$ of $3.14 \mathrm{~m}^{2}$ (Fig. 3.11). Season and sex did not influence 
diurnal refuge use by wētā in terms of refuge height and gorse cover (season $t=2.036$, $p=0.051$, sex $\mathrm{t}=1.237, p=0.2251$ ). MGW radiotracked in gorse habitat were predominantly recorded in unbrowsed bushes during summer ( $74 \%$ of 68 observations), autumn ( $90 \%$ of 204 observations) and spring ( $82 \%$ of 150 observations), regardless of $\operatorname{sex}(z=-1.133, p=0.257$; Fig. 3.12). Radiotracked wētā were much less frequently recorded using semi-browsed bushes (summer $25 \%$, autumn $9 \%$, and spring $21 \%$ ) and on only two occasions in summer (3\%) were wētā observed in browsed bushes. The proportion of MGW taking refuge in semi-browsed gorse bushes in summer was found to be significantly larger than the proportion recorded in autumn ( $z=-2.547, p=0.011)$. Summer and spring proportions did not significantly differ.

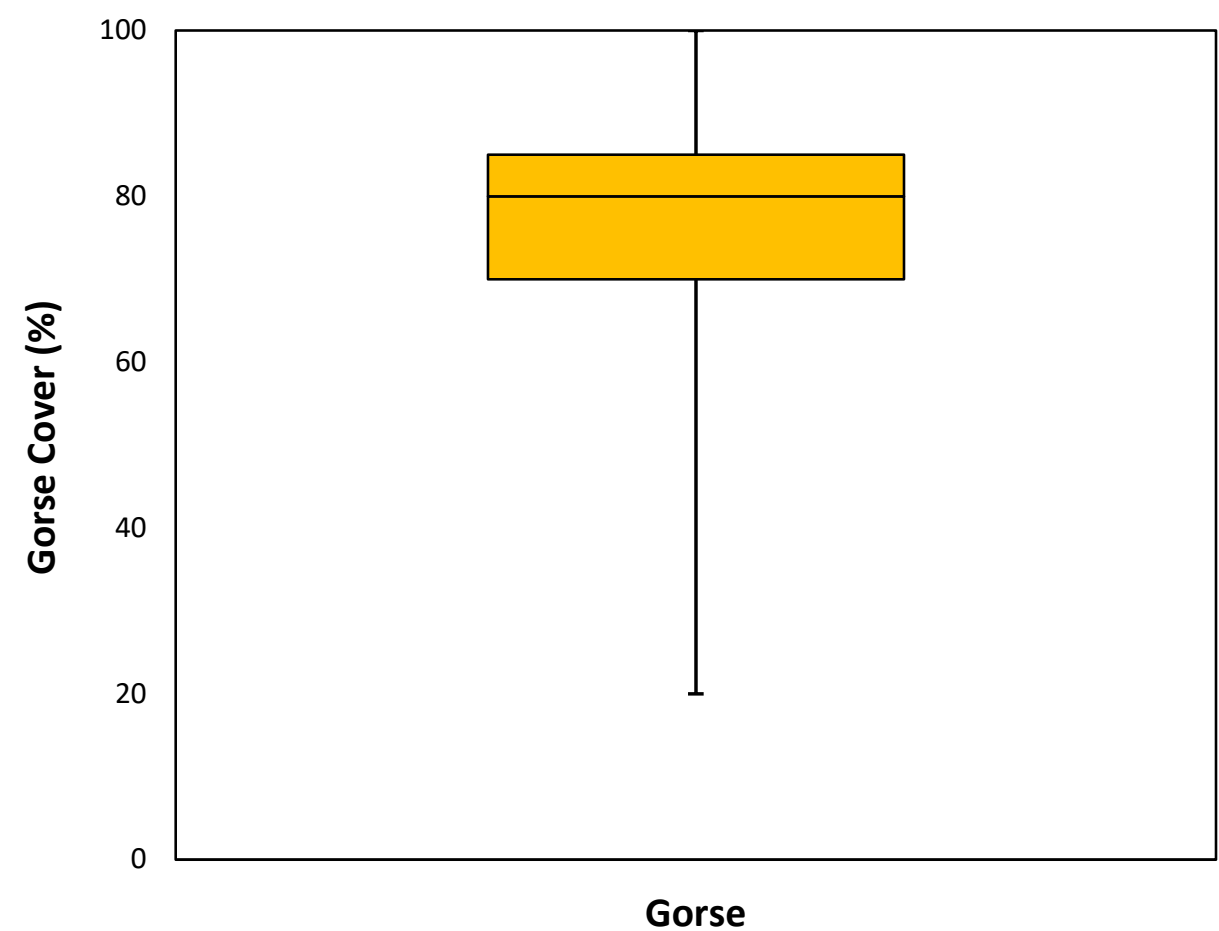

Figure 3.11 The range of gorse cover (\%) within $3.14 \mathrm{~m}^{2}$ of radiotracked MGW diurnal refuges ( $n=378$ observations). Measures were taken from visually located wētā only. Data from summer, autumn and spring radiotracking periods and male and female MGW have been combined due to no significant effects of season or sex. 


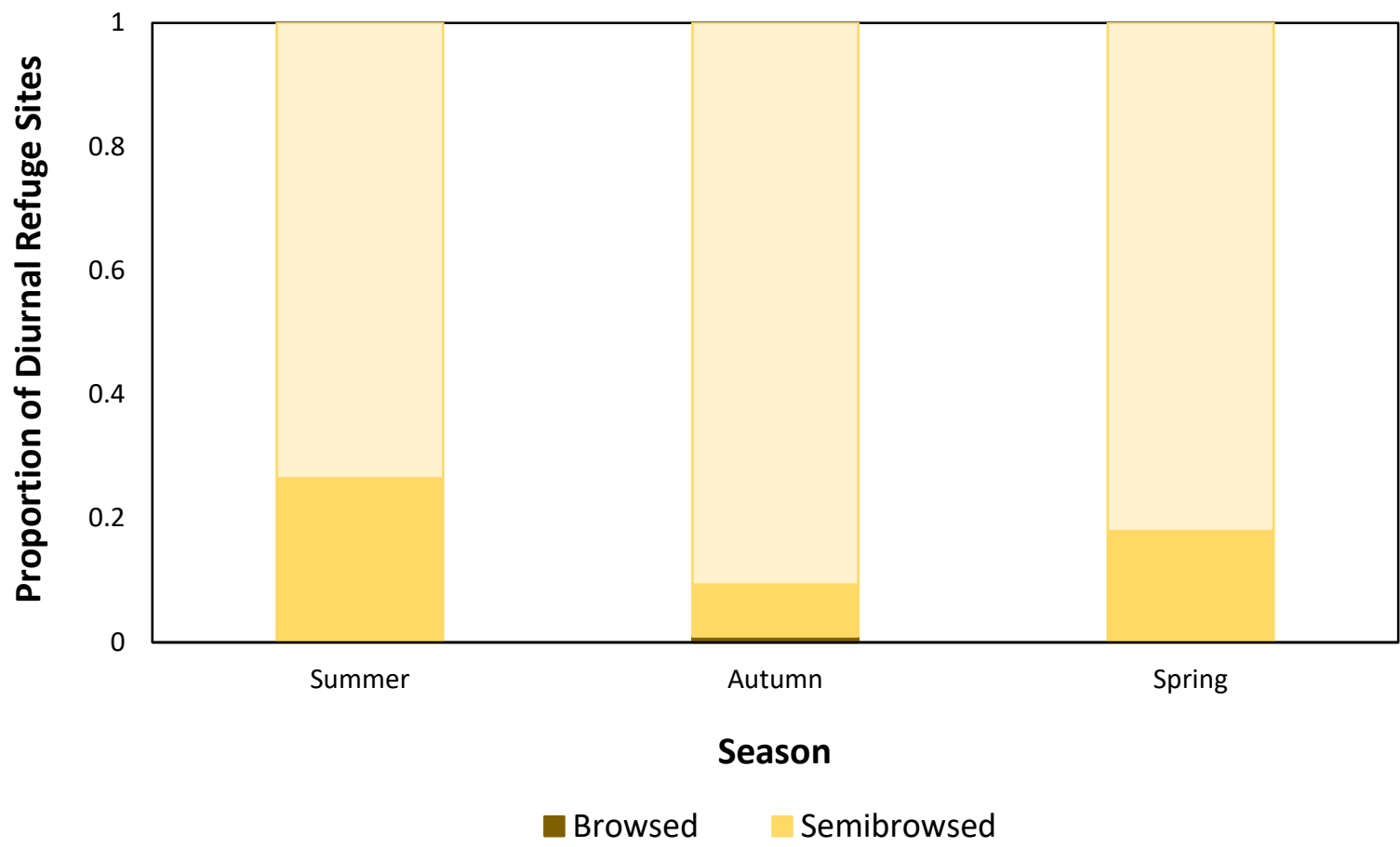

Figure 3.12 Proportion of radiotracked MGW diurnal refuge sites in browsed, semi-browsed, or unbrowsed gorse during summer2016/2017 and autumn and spring 2018.

In terms of vegetation species used, MGW radiotracked in native habitat were only located in mahoe (53\% of 180 day-fixes) and tree ferns ( $28 \%$ of 180 day-fixes; Fig. 3.13). Due to difficulties locating and observing MGW in native habitat, we were unable to distinguish whether wētā were in mahoe foliage or tree fern fronds at 32 (18\%) day-fixes. On one occasion, a female MGW was recorded on the ground (1\%) during a day-fix in native habitat. MGW radiotracked in gorse habitat were predominantly located in gorse bushes ( $93 \%$ of 372 day-fixes; Fig. 3.14). Although other native and invasive plant species are becoming more abundant throughout the gorse habitat, MGW were rarely observed using them. Wētā were recorded taking refuge in ground fern, tree fern, Coprosma spp. and foxglove but only on $2 \%$, $2 \%, 1 \%$ and $0.5 \%$ of 372 day-fixes, respectively. On seven occasions (2\%), male and female MGW were recorded on the ground in gorse habitat during a day-fix. 


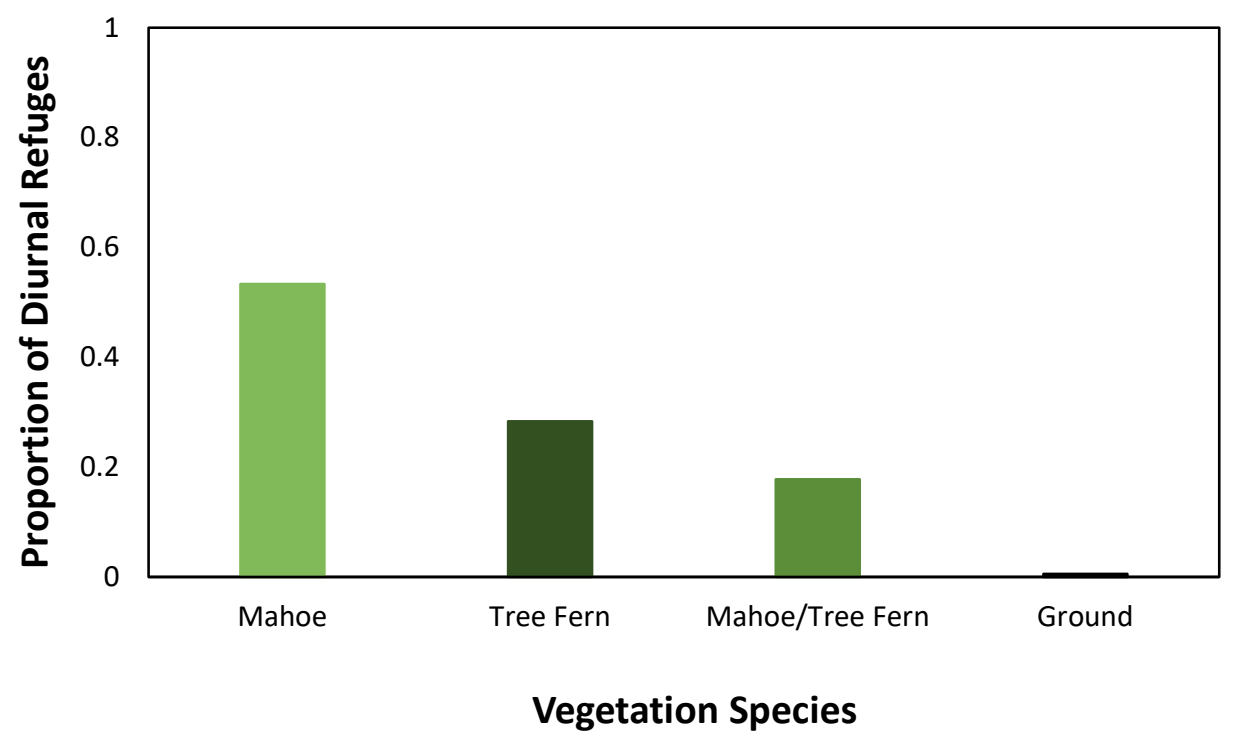

Figure 3.13 Proportion of radiotracked MGW diurnal refuges located in mahoe, tree fern, or on the ground during summer and autumn in native habitat.

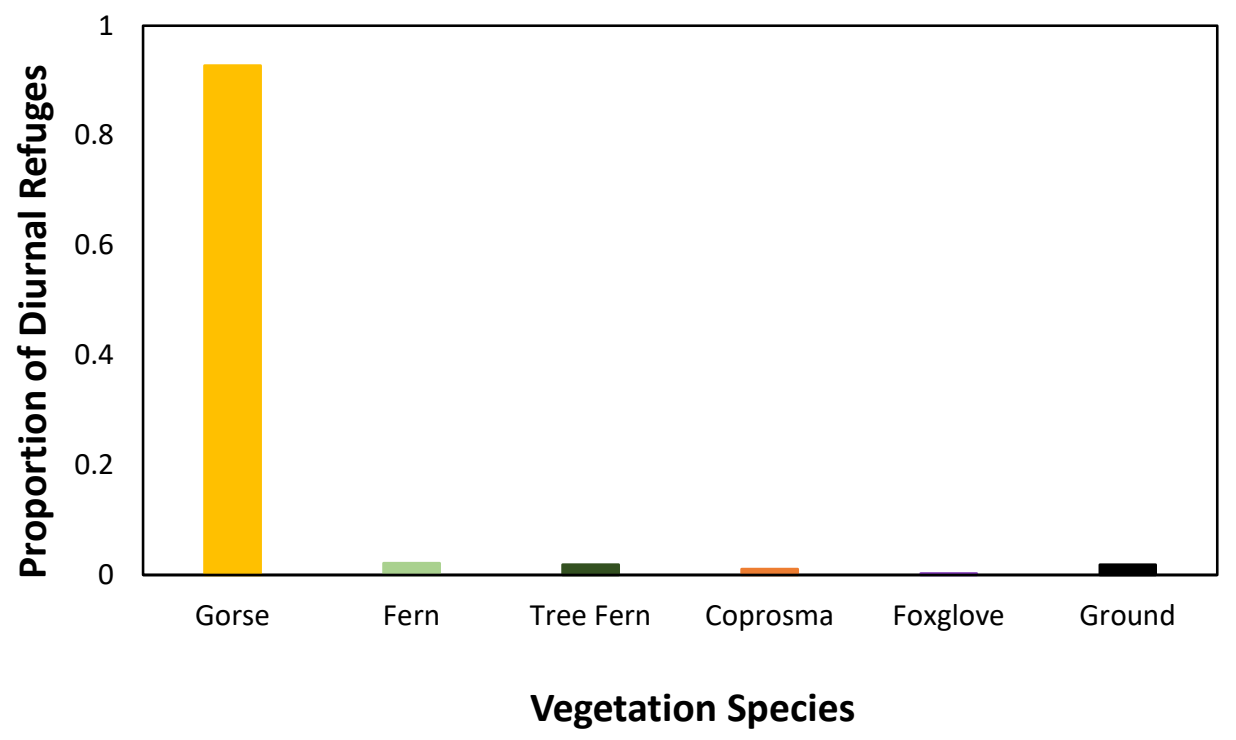

Figure 3.14 Proportion of radiotracked MGW diurnal refuges located in gorse, ground fern, tree fern, Coprosma spp., foxglove, or on the ground during summer, autumn, and spring in gorse habitat. 


\subsection{Discussion}

\subsubsection{Survival of MGW}

The survival rates of adult MGW in the MGWSR were previously unknown. This study found seasonal differences in survival rates between summer, autumn, and spring radiotracking periods. No predation events occurred in either gorse or native habitats over a three-week period during summer. However, a total of 14 wētā for three release categories (original gorse, translocated gorse, and native) could be considered a small sample size, and therefore this result should be accepted with caution.

High predation rates were observed during autumn radiotracking, specifically in the native habitat. It is unknown if MGW are naturally inhabiting the native dominated valley in the MGWSR. Twelve hours of searching was conducted at the beginning the project (2016) in attempt to confirm this, but no wētā were found and the majority of potential refuges were above two metres (unsearchable) due to understory browsing by goats, sheep, and cattle. The lack of protective foliage and natural refuges suggested it was likely an unsuitable habitat for MGW in the presence of mammalian predators.

MGW are believed to have historically inhabited remnant tawa forests (Richards, 1994; Watts et al., 2013) and over a number of generations have become behaviourally habituated to finding refugia and surviving in a much different vegetation, such as introduced gorse (Mclntyre, 2001). Similar behavioural adaptations have been recorded in other species. For example, multi-generational monitoring of Wellington tree wētā ( $H$. crassidens ) on Nukuwaiata Island (Pelorus Sound, Cook Strait) following the eradication of kiore (R. exulans) revealed that tree wētā living in the absence of mammals occupied galleries closer to the ground with larger entrance holes and displayed 'relaxed' foraging behaviour, spending more time away from galleries compared to wētā living alongside mammalian predators (Rufaut \& Gibbs, 2003). Similar behavioural changes in D. heteracantha were observed five-years following the eradication kiore on Little Barrier Island, as wētā were regularly seen with little cover or fully exposed (Green et al., 2011). The MGW we translocated into native habitat without an adjustment period were likely behaviourally naïve and unfamiliar with refugia in native vegetation that would provide some protection, potentially exposing themselves to a higher risk of predation. 
During autumn, we recorded two predations in the gorse habitat. Giant wētā are generally thought to be more vulnerable in autumn due to mating behaviour (Watts et al., 2013), and peak mammalian predator abundance (Miller \& Miller, 1995; Quinnell, 2015; Chapter 2). In this study, MGW were not observed engaging in mating behaviour during autumn (Section 3.4.4), but it still appears to be a vulnerable time as no predations occurred in the gorse habitat during summer or spring. The much lower predation rate in the gorse habitat in autumn and no predations during summer and spring suggests that gorse does provide significantly better protection to wētā than native vegetation.

The survival rate of juvenile and sub-adult MGW in the MGWSR is unknown and difficult to assess in the field due to restrictions with transmitter use. High mortality rates have been observed in MGW nymphs bred in captivity (Richards, 1994). Cannibalism was recorded as the main cause of death and mortality rates decreased as wētā advanced to later nymphal stages (Richards, 1994). In the MGWSR, juveniles and eggs face potential predation by mammals as well. Large increase in the number of Cook Strait giant wētā (D. rugosa) seen on Mana Island (Wellington, New Zealand) following the eradication of mice (Mclntyre, 2001). As adult giant wētā can survive in the presence of mice (Watts et al., 2012) the population increase McIntyre (2001) reported on Mana Island is likely due to the release of predation pressure on juveniles and eggs (Watts, 2001).

\subsubsection{Movement patterns of MGW}

MGW appear to vary their movement depending on the season. In the MGWSR we observed average movements over 48 hours of less than $6 \mathrm{~m}$ in autumn compared to significantly larger movements, $5-11 \mathrm{~m}$, in summer and spring. Richards (1994) recorded similar results, finding MGW moved significantly further during warmer months. Daily distances moved by other flightless invertebrates vary largely. For example, dark bush crickets (Pholidoptera griseoaptera) have been recorded moving an average daily distance of $3.2 \mathrm{~m}$ to $11.2 \mathrm{~m}$ in summer (Diekotter et al., 2005), whereas mormon crickets (Anabrus simplex) have been recorded moving average daily distances ranging from $0.66 \mathrm{~m}$ (non-band forming individuals) to $331 \mathrm{~m}$ (band forming individuals) in summer (Lorch et al., 2005). However, MGW appear to be somewhat less mobile than other giant wētā species. $D$. heteracantha were recorded 
moving an average of $4-13$ m over 24 hours on Little Barrier Island (Auckland, New Zealand) in autumn/winter (Watts \& Thornburrow, 2011), and D. rugosa were recorded moving 6 $18 \mathrm{~m}$ per night on Maud island (Marlborough Sounds, New Zealand) in autumn (Kelly et al., 2008). Both wētā studies recorded males moving significantly further than females, which was not the case for MGW in this study. Differences between species could be attributed to factors such as habitat structure, average site temperature, arborealism, predator presence or a combination of these factors.

Net displacement and diffusion results allow us to determine the range in which MGW move. After two weeks of radiotracking, wētā in gorse were found $18-39 m$ from their original site of release in summer and spring and had average diffusion parameters predominantly consistent with random diffusion. Whereas, wētā radiotracked in gorse habitat during autumn moved significantly less from their original release site (4-12m), but still displayed movement patterns consistent with random diffusion. It has been suggested that MGW remain within a $3 \mathrm{~m}^{3}$ home range for most of their lives (Richards, 1994), which would be detected as sub-diffusive movement. Our results suggest that adult MGW in gorse habitat do not remain within a restricted range for the adult portion of their life cycle. Adult MGW appear to predominantly move randomly through the mosaic of gorse rather than staying within a specific home range. This behaviour and lack of home range in adult wētā appears similar to what has been recorded in adult D. rugosa and D. heteracantha (McIntyre, 2001; Kelly et al., 2008; Watts \& Thornburrow, 2011; Watts et al., 2012). Juveniles and sub-adults of these species are more sedentary which may be the case with MGW as suggested by Richards (1994).

Wētā in native vegetation displayed different behaviour between seasons. During autumn, wētā in native vegetation barley moved from their release site and displayed displacement patterns consistent with random or sub-diffusive movement. As discussed above, autumn appears to be a vulnerable time for MGW resulting in a reduction in nocturnal activity. Seasonal cues on top of translocation into unfamiliar habitat may have led to sedentary behaviour. Average movement parameters for male wētā in native vegetation in summer, like male wētā in gorse, were consistent with random diffusion and large net displacement $(53 \mathrm{~m})$ over a two-week period. This behaviour in summer is likely attributed to mate searching, as 
male wētā are known to become more active and seek females at this time of year (Richards, 1994; Stringer, 2001).

For other species of giant wētā, mating behaviour has been observed from summer through to late autumn (Green et al., 2011; Watts \& Thornburrow, 2011) and autumn is often the best time to collect or monitor adult wētā due to their abundance and visibility (C Watts, pers. comm., 2018). MGW in the MGWSR appear to be most active during the summer months and substantially reduce their activity levels during autumn. In addition to this, no mating pairs were observed during autumn (Section 3.4.4). This is contradictory to what has been observed elsewhere with MGW (C Watts, pers. comm., 2018) and other giant wētā species. For example, numerous mating pairs of $D$. heteracantha and $D$. rugosa where observed in autumn (Mar - May) during radiotracking studies on Little Barrier Island (Watts \& Thornburrow, 2011) and in Karori Sanctuary, Wellington (Watts et al., 2012), respectively. A behavioural adaptation for surviving in the presence of mammalian pests could provide a potential explanation. Mating and oviposition behaviours expose MGW to higher risks of predation and thus may be avoided at times when there is an increased predation risk (i.e. autumn; Fitzgerald \& Karl, 1979; Farnworth et al., 2018). Alternatively, the cooler climate at Mahoenui compared to more northern locations where giant wētā are present may influence the timing of MGW mating behaviour. However, these speculations would require further exploration to confirm.

Average daily temperature appears to have a general influence on the activity of giant wētā. Watts and Thornburrow (2011) found D. heteracantha moved significantly further between consecutive daytime refuges as daily average temperatures increased above $12^{\circ} \mathrm{C}$. Similarly, the nocturnal activity of $D$. rugosa was found to be influenced by ambient temperature, specifically that more adults were seen on warmer nights (McIntyre, 2001). MGW in this study demonstrated the same trend in relation to increasing average temperature in spring. Increased activity in warmer temperatures has additionally been recorded for stag beetles (Lucanus cervus; Rink \& Sinsch, 2007), and ground beetles (Carabus ullrichii; Ruzickova \& Vesely, 2016). Precipitation on the other hand had no effect on average movement. 


\subsubsection{Diurnal refuge use in gorse and native vegetation.}

Assessing diurnal refuge use is important for understanding the habitat MGW are most likely use and where they would be found in gorse and native vegetation. In gorse dominated habitat, MGW were seen much more frequently during radiotracking than those in the native dominated habitat. Mating was observed in summer and spring which correlates to the increased movement activity recorded during these seasons compared to autumn (Section 3.4.3). Prior to this study, it was generally thought that MGW were active and mating through until late autumn, as seen in other giant wētā species (Green et al., 2011; Watts \& Thornburrow, 2011). However, this appears not to be the case in the MGWSR. This may be due to a behavioural survival adaptation (Discussed in section 3.5.2; Fitzgerald \& Karl, 1979; Farnworth et al., 2018), differing climate conditions in the reserve compared to the locations of other giant wētā, or something else entirely.

MGW radiotracked in gorse dominated habitat were generally found mid height in unbrowsed gorse bushes where gorse cover was approximately $80 \%$, but were also observed using other vegetation species on a few occasions. In a previous study that recorded MGW diurnal refuge site characteristics, it was noted that $61 \%$ of wētā were found taking refuge in the lower portion of the gorse bush $(0-1 \mathrm{~m})$ and that $48 \%$ of wētā were found where gorse cover was between 67-100\% (Sherley \& Hayes, 1993). Likewise, Richards (1994) recorded MGW taking refuge in the browsed part of semi-browsed bushes most frequently compared to the unbrowsed section. From these two studies, it appears goat browse and denser gorse cover were important characteristics for MGW diurnal refuge selection (Sherley \& Hayes, 1993; Richards, 1994). Browsed and semi-browsed gorse bushes are now much rarer within the reserve compared to 14 years ago (Chapter 2), which may explain why MGW were most frequently observed in unbrowsed gorse bushes in our study, despite their suggested preference for browsed bushes. In addition, the browsed section of the gorse bush, having impenetrable foliage, may have provided safe diurnal refuge sites closer to the ground compared to those inhabiting unbrowsed bushes.

MGW diurnal refuge use in native vegetation has been somewhat assessed in the past in pestfree habitats (Watts \& Thornburrow, 2009). However, it was not known if MGW were present in the native dominated valley within the MGWSR and where they would take refuge in the presence of mammalian predators. From radiotracking MGW in the native habitat, we found 
wētā most commonly used mahoe and tree ferns for day refuges, although this may not represent selective use as these were the dominant species in the native habitat. We additionally found MGW generally took refuge above $2.5 \mathrm{~m}$ up in the mahoe canopy or at the top of tree ferns among fronds, stipes, or in the crown.

In native habitats where browsers and mammalian pests are absent, giant wētā and other invertebrates can be found closer to the ground. For example, MGW translocated to pest-free Warrenheip 17 years ago are now commonly found in the debris around the bases of tree ferns or on the trunk of tree ferns at heights of $<2 \mathrm{~m}$ (Watts and Thornburrow, 2009). Likewise, ground dwelling invertebrates such as Falkland camel crickets (Parudenus spp.; St Clair et al., 2011), ground beetles (Carabidae), earwigs (Dermaptera), and cockroaches (Blattodea; Towns et al., 1997) were found to generally increase in abundance following the eradication of mammalian predators. As MGW are an arboreal species historically inhabiting tawa forests (Richards, 1994), it would not be unusual for them to take refuge $>2 \mathrm{~m}$. Another arboreal giant wētā species, $D$. heteracantha, was recorded predominantly using diurnal refugia in mammalfree native habitat $>2 m$ off the ground (Watts \& Thornburrow, 2011). On $44 \%$ and $38 \%$ of occasions radiotracked $D$. heteracantha were recorded at $2-4 m$ and $>4 m$ height, respectively (Watts \& Thornburrow, 2011).

The lack of protective foliage and natural refuges in the MGWSR's native dominated habitat, suggests it is an unsuitable habitat for MGW in the presence of mammalian predators. Furthermore, in this study we recorded a high predation rate of radiotracked wētā translocated into the native habitat (Section 3.4.2). Therefore, it is unlikely MGW inhabit the native habitat in the MGWSR, but arboreal monitoring would be required to confirm this.

\subsubsection{Radio-transmitters as a monitoring tool for MGW}

Transmitters are a valuable tool for monitoring animals in the field, especially cryptic and nocturnal species such as the MGW (Watts \& Thornburrow, 2009). Manual searches for giant wētā, especially MGW inhabiting gorse, can be extremely time consuming and restricts the type of data that can be collected (Gibbs \& McIntyre, 1997). In this study, transmitters allowed us to follow and observe individual wētā and record survival and behavioural data that would otherwise be impossible to collect. It is common practice when fitting transmitters to ensure 
the transmitter to animal body weight percentage does not exceed 10\% (Sedgeley et al., 2012; DOC, 2017). For giant wētā, there are numerous studies that have found when transmitter to body weight percentages are less than $10 \%$ there is no adverse effect on average distance moved (Watts et al., 2011; Watts \& Thornburrow, 2011; Watts et al., 2012). Likewise, a study assessing daily movement of mormon crickets in Utah and Colorado, USA, reported transmitters had no effects on short-term movement behaviour (Lorch et al., 2005). This result was also observed in this study. Furthermore, wētā were observed mating within 24 $48 \mathrm{hrs}$ of release during summer and spring (Section 3.4.4). These results and observations suggest transmitters have little or no impact on a wētā's behaviour.

From radiotracking MGW in this study we identified that wētā are vulnerable to predation in native habitat and are unlikely to be inhabiting the native vegetation in the reserve. Furthermore, we found that wētā move significantly less in autumn compared to summer and spring, but generally move randomly throughout the gorse instead of staying within a home range for their adult life. MGW movement was also found to be influenced by ambient temperature, whereby wētā moved further in warmer weather $\left(>13.5^{\circ} \mathrm{C}\right)$. From these results we recommend the implementation of mammalian pest control as a starting point to help improve wētā survival probabilities and a long-term management solution such as a predator excluding fence or gorse gardening (e.g. Chapter 5). Further assessment of MGW survival, movement patterns, behaviour, and diurnal refuge use in pest-free habitats is also needed. 


\subsection{Appendices}

Appendix 3.1 Measurements of wētā taken to determine instar and size. Pronotum and head in at longest or widest point respectively. Diamond split in ovipositor indicates female is mature and depositing eggs.

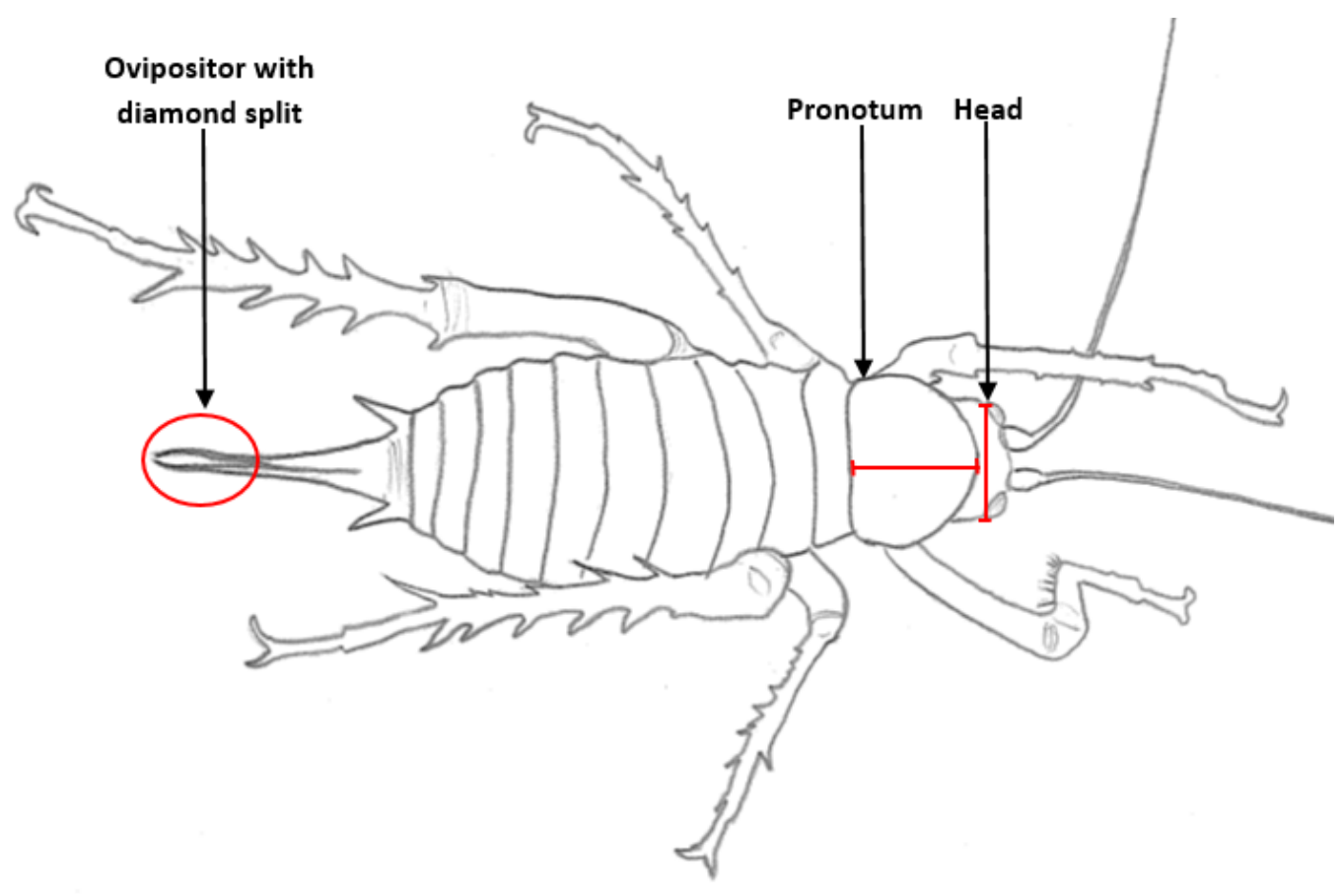

Appendix 3.2 (A) Estimated size ranges of MGW instars in the MGWSR taken from Sherley and Hayes (1993), and (B) estimated size ranges of MGW instars bred in captivity taken from Richards (1994).

\begin{tabular}{lccccccc}
\hline (A) & \multicolumn{7}{c}{ INSTAR } \\
\hline Males & 10 & 9 & 8 & 7 & 6 & 5 & $<4$ \\
\hline Mass (g) & $6.0-10.5$ & $5.0-5.9$ & $3.9-4.9$ & $3.0-3.8$ & $2.0-2.9$ & $1.0-1.9$ & $0-0.9$ \\
Pronotum (mm) & $10.0-12.0$ & $8.6-9.9$ & $7.2-8.5$ & $6.1-7.1$ & $5.1-6.0$ & $3.8-5.0$ & $2.7-3.7$ \\
Head capsule (mm) & $9.0-11.0$ & $7.9-8.9$ & $6.6-7.8$ & $5.5-6.5$ & $4.8-5.4$ & $3.9-4.7$ & $2.2-3.8$ \\
\hline Females & & & & & & & \\
\hline Mass (g) & $9.6-19.0$ & $8.1-9.5$ & $7.0-8.0$ & $5.6-6.9$ & $4.1-5.5$ & $1.3-4.0$ & $0.2-1.2$ \\
Pronotum (mm) & $11.0-13.3$ & $9.6-10.9$ & $7.8-9.5$ & $6.1-7.7$ & $5.0-6.0$ & $4.1-4.9$ & $3.5-4.0$ \\
Head capsule (mm) & $10.3-12.0$ & $8.9-10.2$ & $7.5-8.8$ & $5.7-7.4$ & $4.9-5.6$ & $4.0-4.8$ & $3.4-3.9$ \\
\hline
\end{tabular}

Mass was derived from 530 male and 461 female wētā. Maximum pronotum length was derived from 495 male and 414 female wētā. Maximum head capsule width was derived from 255 male and 201 female wētā. 
(B)

\begin{tabular}{lcccccccccc}
\hline Males & 10 & 9 & 8 & 7 & 6 & 5 & 4 & 3 & 2 & 1 \\
\hline Mass $(\mathrm{g})$ & $5.8-9.2$ & $3.1-7.9$ & $1.7-4.9$ & $1.1-2.7$ & $0.9-1.5$ & $0.6-0.8$ & $0.2-0.5$ & $0.1-0.3$ & $0.07-0.13$ & $0.03-0.06$ \\
Pronotum (mm) & $9.9+$ & $8.6-9.8$ & $7.3-8.5$ & $6.0-7.2$ & $4.8-5.9$ & $3.9-4.7$ & $3.1-3.7$ & $2.5-3.0$ & $2.0-2.4$ & $1.5-1.9$ \\
Head capsule (mm) & $9.2+$ & $7.9-9.1$ & $6.8-7.8$ & $5.7-6.7$ & $4.8-5.6$ & $3.9-4.7$ & $3.2-3.8$ & $2.8-3.1$ & $2.3-2.7$ & $1.6-2.2$ \\
\hline Females & & & & & & & & & & \\
\hline Mass (g) & $7-21$ & $3.9-9.1$ & $2.2-5.0$ & $1.5-3.3$ & $0.7-1.6$ & $0.5-0.8$ & $0.2-0.5$ & $0.1-0.3$ & $0.07-0.13$ & $0.03-0.06$ \\
Pronotum (mm) & $10.4+$ & $8.9-10.3$ & $7.5-8.8$ & $6.1-7.4$ & $4.8-6.0$ & $3.9-4.7$ & $3.1-3.7$ & $2.5-3.0$ & $2.0-2.4$ & $1.5-1.9$ \\
Head capsule (mm) & $9.2+$ & $7.9-9.1$ & $6.8-7.8$ & $5.7-6.7$ & $4.8-5.6$ & $3.9-4.7$ & $3.2-3.8$ & $2.8-3.1$ & $2.3-2.7$ & $1.6-2.2$ \\
\hline
\end{tabular}

Mass was derived from 55 male and 63 female wētā. Pronotum length was derived from 194 male and 205 female wētā. Head capsule width was derived from 194 male and 205 female wētā. Male and female measurement are combined for instars 1-3 as sex is unable to be determined.

Appendix 3.3 Transmitter (0.62g BD-2) attached to a female MGW.

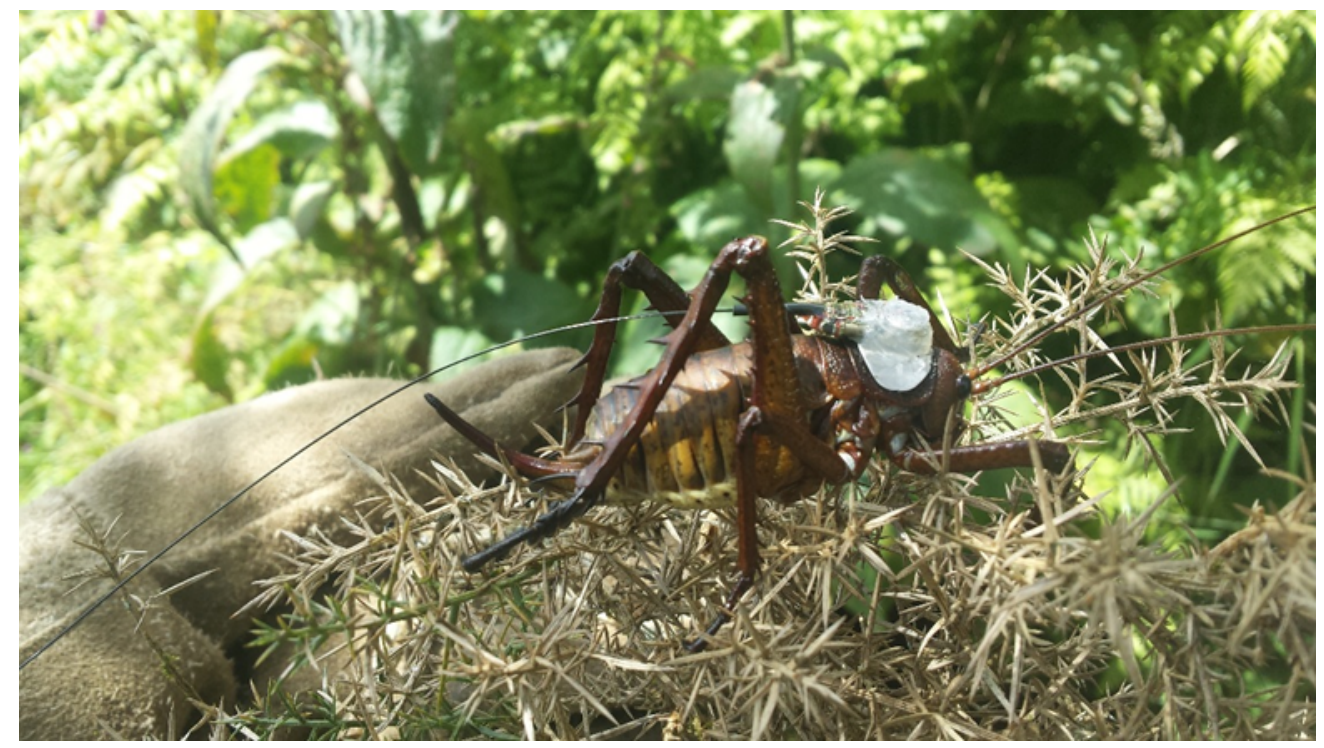


Appendix 3.4 (A) Summary of plot characteristics based off Sutton (2004) and (B) examples of gorse browse categories- 1)Browsed, 2)Semi-browsed, and 3) Unbrowsed (Drawn images taken from Sutton (2004)).

\section{(A) Characteristic Description}

\begin{tabular}{|c|c|}
\hline Browse & $\begin{array}{l}\text { Structure of a gorse bush within a plot defined by three categories - Browsed (small } \\
\text { gorse bush rounded due to heavy goat browsing), semi-browsed ( }>30 \% \text { of bush }<1 \mathrm{~m} \text { is } \\
\text { browsed, no browse }>1 \mathrm{~m} \text { ), and unbrowsed (gorse bush branching and sprawling due } \\
\text { to lack of browsing). See (B) for examples. }\end{array}$ \\
\hline Height & $\begin{array}{l}\text { The height }(m) \text { of the gorse bush within a plot defined by Three categories }- \text { low }<1 m \text {, } \\
\text { medium } 1-2 m \text {, and high }>2 m \text {. }\end{array}$ \\
\hline Cover & $\begin{array}{l}\text { The percentage of gorse cover within a plot defined by four categories }-0-25 \%, 25- \\
49 \%, 50-75 \% \text {, and }>75 \% \text {. }\end{array}$ \\
\hline
\end{tabular}

(B)
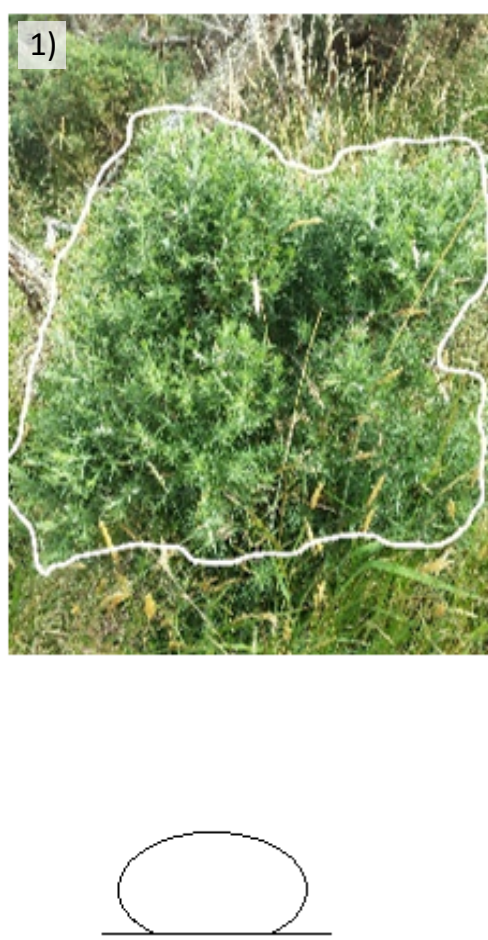
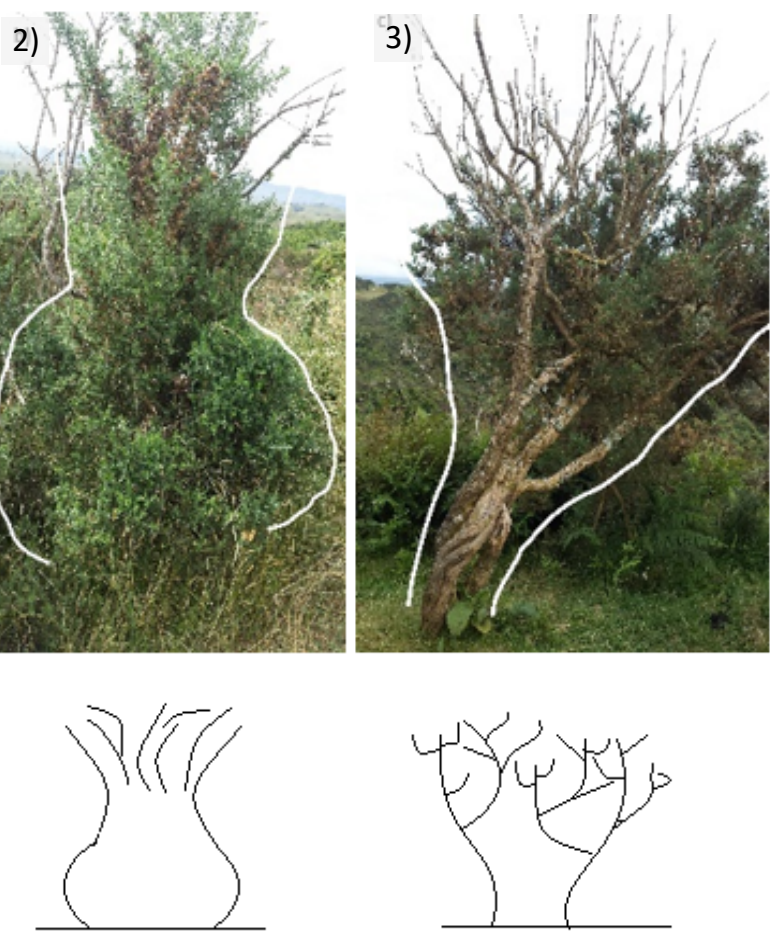
Appendix 3.5 Summary of data collected from radiotracking MGW in summer 2016/2017, autumn 2018, and spring 2018. All distances are in metres. Outcome is the status of the wētā at the end of the radiotracking period where 'Alive' is wētā still known to be alive, 'predated' is wētā that died due to suspected predation, 'Died naturally' is wētā that died of causes other than predation, 'Tx died' is wētā lost due to transmitter battery expiry, and 'Tx drop' is wētā lost due to the transmitter falling off.

Summer 2016/2017

\begin{tabular}{|c|c|c|c|c|c|c|c|}
\hline $\begin{array}{c}\text { Wētā } \\
\text { number }\end{array}$ & Sex & Release habitat & $\begin{array}{l}\text { Days } \\
\text { tracked }\end{array}$ & $\begin{array}{c}\text { Total } \\
\text { distance } \\
\text { moved }(m)\end{array}$ & $\begin{array}{c}\text { Average } \\
\text { distance } \\
\text { (m) }\end{array}$ & $\begin{array}{l}\text { Maximum } \\
\text { distance } \\
\text { (m) }\end{array}$ & Outcome \\
\hline \#50.2 & $\mathrm{F}$ & Original gorse & 21 & 132.7 & 6.3 & 45 & Alive \\
\hline \#56 & M & Original gorse & 21 & 138 & 6.6 & 36 & Alive \\
\hline \#62 & $\mathrm{F}$ & Original gorse & 18 & 73.5 & 4.1 & 40 & Died naturally \\
\hline \#76 & M & Original gorse & 15 & 88.5 & 5.9 & 50 & Alive \\
\hline \#80 & $\mathrm{F}$ & Original gorse & 22 & 68 & 3.1 & 18 & Alive \\
\hline \#82 & $M$ & Original gorse & 11 & 26.3 & 2.4 & 20 & Died naturally \\
\hline \#52 & $\mathrm{F}$ & $\begin{array}{l}\text { Translocated } \\
\text { gorse }\end{array}$ & 21 & 106 & 5 & 38 & Alive \\
\hline \#54.3 & $\mathrm{F}$ & $\begin{array}{l}\text { Translocated } \\
\text { gorse }\end{array}$ & 15 & 66 & 4.4 & 33 & Alive \\
\hline \#64 & M & $\begin{array}{l}\text { Translocated } \\
\text { gorse }\end{array}$ & 20 & 30.5 & 1.5 & 10 & Died naturally \\
\hline \#82.1 & M & $\begin{array}{l}\text { Translocated } \\
\text { gorse }\end{array}$ & 9 & 65 & 7.2 & 20 & Alive \\
\hline \#26 & $M$ & Native & 22 & 327 & 14.9 & 110 & Alive \\
\hline \#58 & $\mathrm{F}$ & Native & 21 & 55 & 2.6 & 15 & Alive \\
\hline \#60 & $M$ & Native & 21 & 127 & 6 & 36 & Alive \\
\hline \#76.1 & $M$ & Native & 10 & 156 & 15.6 & 50 & Alive \\
\hline
\end{tabular}


Autumn 2018

\begin{tabular}{|c|c|c|c|c|c|c|c|}
\hline $\begin{array}{c}\text { Wētā } \\
\text { number }\end{array}$ & Sex & Release habitat & $\begin{array}{l}\text { Days } \\
\text { tracked }\end{array}$ & $\begin{array}{c}\text { Total } \\
\text { distance } \\
\text { moved }(m)\end{array}$ & $\begin{array}{c}\text { Average } \\
\text { distance } \\
\text { (m) }\end{array}$ & $\begin{array}{c}\text { Maximum } \\
\text { distance } \\
\text { (m) }\end{array}$ & Outcome \\
\hline \#45 & $M$ & Translocated gorse & 22 & 14.4 & 1.2 & 6 & Alive \\
\hline \#62 & $\mathrm{F}$ & Translocated gorse & 38 & 130 & 6.190 & 30 & Died naturally \\
\hline \#63 & $M$ & Translocated gorse & 44 & 149.4 & 6.225 & 47 & Predated \\
\hline$\# 64$ & $\mathrm{~F}$ & Original gorse & 44 & 10.5 & 0.457 & 5 & Alive \\
\hline \#66 & $\mathrm{F}$ & Original gorse & 18 & 13.6 & 1.36 & 10 & $\begin{array}{l}\text { Tx } \\
\text { drop/Predated? }\end{array}$ \\
\hline \#67 & $\mathrm{F}$ & Original gorse & 44 & 43.1 & 1.891 & 16 & Alive \\
\hline \#70 & $M$ & Original gorse & 9 & 106 & 26.5 & 55 & Tx drop \\
\hline \#72 & $M$ & Original gorse & 44 & 16.85 & 0.732 & 15 & Alive \\
\hline \#74 & $\mathrm{F}$ & Translocated gorse & 35 & 66.22 & 4.139 & 22 & Tx died \\
\hline \#76 & $M$ & Translocated gorse & 43 & 174.6 & 7.591 & 45 & Alive \\
\hline \#79 & $M$ & Translocated gorse & 35 & 7.9 & 0.416 & 2 & Predated \\
\hline \#98 & $\mathrm{F}$ & Translocated gorse & 18 & 22.1 & 2.456 & 8 & Alive \\
\hline \#01 & $\mathrm{F}$ & Native & 1 & 4 & 4 & 4 & Tx drop \\
\hline \#09 & $\mathrm{F}$ & Native & 21 & 9.5 & 0.731 & 3 & Predated \\
\hline \#15 & $\mathrm{F}$ & Native & 1 & 9 & 9 & 9 & Predation \\
\hline \#22 & $M$ & Native & 1 & 20 & 20 & 20 & Tx drop \\
\hline \#37 & $M$ & Native & 4 & 2 & 0.667 & 2 & Predated \\
\hline \#38 & $M$ & Native & 29 & 3 & 0.188 & 1.5 & Alive \\
\hline \#40 & $\mathrm{F}$ & Native & 17 & 15.5 & 1.55 & 10 & Predated \\
\hline \#41 & $M$ & Native & 18 & 34.5 & 3.45 & 19 & Tx died \\
\hline \#42 & $M$ & Native & 23 & 10 & 0.769 & 4 & Predated \\
\hline \#61 & $\mathrm{F}$ & Native & 25 & 0 & 0 & 0 & Predated \\
\hline \#65 & $\mathrm{F}$ & Native & 2 & 49 & 49 & 49 & Predation \\
\hline \#68 & $\mathrm{F}$ & Native & 39 & 17.5 & 0.833 & 7 & Alive \\
\hline \#69 & $\mathrm{F}$ & Native & 23 & 10 & 0.909 & 10 & Predated \\
\hline \#71 & $M$ & Native & 14 & 14.5 & 2.071 & 12 & Tx died \\
\hline \#73 & $M$ & Native & 10 & 8 & 1.333 & 4 & Predated \\
\hline \#75 & $\mathrm{F}$ & Native & 12 & 6 & 0.857 & 2.5 & Died naturally \\
\hline \#77 & $M$ & Native & 30 & 11.5 & 0.676 & 4 & Predated \\
\hline \#78 & $M$ & Native & 5 & 5 & 2.5 & 5 & Predated \\
\hline$\# 80$ & $M$ & Native & 22 & 7 & 0.583 & 5 & Predated \\
\hline
\end{tabular}


Spring 2018

\begin{tabular}{lllccccl}
\hline $\begin{array}{c}\text { Wētā } \\
\text { number }\end{array}$ & Sex & Release habitat & $\begin{array}{c}\text { Days } \\
\text { tracked }\end{array}$ & $\begin{array}{c}\text { Total } \\
\text { distance } \\
\text { moved }(\boldsymbol{m})\end{array}$ & $\begin{array}{c}\text { Average } \\
\text { distance } \\
(\boldsymbol{m})\end{array}$ & $\begin{array}{c}\text { Maximum } \\
\text { distance } \\
(\boldsymbol{m})\end{array}$ & Outcome \\
\hline$\# 77$ & $\mathrm{~F}$ & Original gorse & 16 & 45.72 & 3 & 12 & Tx died \\
$\# 84$ & $\mathrm{~F}$ & Original gorse & 16 & 94.8 & 6.3 & 20 & Tx died \\
$\# 85$ & $\mathrm{M}$ & Original gorse & 16 & 116.1 & 7.7 & 25 & Tx died \\
$\# 88$ & $\mathrm{M}$ & Original gorse & 19 & 2.5 & 0.1 & 2.5 & Alive \\
$\# 90$ & $\mathrm{M}$ & Original gorse & 19 & 162.8 & 9.6 & 31 & Alive \\
$\# 44$ & $\mathrm{M}$ & Translocated gorse & 19 & 53.6 & 3.3 & 22 & Alive \\
$\# 47$ & $\mathrm{~F}$ & Translocated gorse & 19 & 29.1 & 1.7 & 14 & Alive \\
$\# 78$ & $\mathrm{~F}$ & Translocated gorse & 19 & 58.1 & 3.4 & 17 & Alive \\
$\# 92$ & $\mathrm{M}$ & Translocated gorse & 18 & 102.8 & 6.4 & 27 & Tx died \\
$\# 94$ & $\mathrm{~F}$ & Translocated gorse & 18 & 82.5 & 5.2 & 17 & Tx died \\
\hline
\end{tabular}

Appendix 3.6 Summary of wētā that died during radiotracking of causes other than predation. Assumed to be natural causes.

\begin{tabular}{|c|c|c|c|c|c|c|}
\hline Season & Wētā & Sex & $\begin{array}{l}\text { Days } \\
\text { tracked }\end{array}$ & Habitat & Behaviour before death & Location at death \\
\hline \multirow[t]{3}{*}{ Summer } & 62 & $\mathrm{~F}$ & 18 & $\begin{array}{l}\text { Original } \\
\text { gorse }\end{array}$ & $\begin{array}{l}\text { Observed on ground or very close } \\
\text { to regularly. Day before death } \\
\text { climbed } 2 \mathrm{~m} \text { up into gorse bush }\end{array}$ & $\begin{array}{l}\text { On ground among tall } \\
\text { pasture. Semi open area }\end{array}$ \\
\hline & 64 & $M$ & 20 & $\begin{array}{l}\text { Unfamiliar } \\
\text { Gorse }\end{array}$ & $\begin{array}{l}\text { Observed }<1 \mathrm{~m} \text { high regularly. Day } \\
\text { before death was observed near } \\
\text { ground amongst pasture and } \\
\text { gorse. }\end{array}$ & $\begin{array}{l}\text { Found on Foxgolve } \\
\text { (Digitalis spp.) leaves } 5 \mathrm{~cm} \\
\text { from ground out in open. }\end{array}$ \\
\hline & 82.1 & $M$ & 11 & $\begin{array}{l}\text { Original } \\
\text { Gorse }\end{array}$ & $\begin{array}{l}\text { Observed }<0.5 \mathrm{~m} \text { high regularly. } \\
\text { Few days before death was } \\
\text { observed just off ground amongst } \\
\text { pasture at edge of browsed bush. }\end{array}$ & $\begin{array}{l}\text { Found on ground amongst } \\
\text { pasture out in open. }\end{array}$ \\
\hline \multirow[t]{2}{*}{ Autumn } & 62 & $\mathrm{~F}$ & 38 & $\begin{array}{l}\text { Unfamiliar } \\
\text { Gorse }\end{array}$ & $\begin{array}{l}\text { Little movement until few days } \\
\text { before death, } 56 \mathrm{~m} \text { over } 5 \text { days. }\end{array}$ & $\begin{array}{l}\text { Found on ground among } \\
\text { pasture and fern. }\end{array}$ \\
\hline & 75 & $\mathrm{~F}$ & 11 & $\begin{array}{l}\text { Unfamiliar } \\
\text { Native }\end{array}$ & $\begin{array}{l}\text { Observed every } 48 \mathrm{hrs} \sim 3 \mathrm{~m} \text { high in } \\
\text { native vegetation. Moved down to } \\
\text { ground day before death. }\end{array}$ & $\begin{array}{l}\text { Found on ground among } \\
\text { pasture out in open }\end{array}$ \\
\hline
\end{tabular}


Appendix 3.7 Movement of radiotracked MGW during summer (A.1 \& A.2 =Gorse habitat; A.3=Native habitat), autumn (B.1 \& B.2=Gorse habitat; B.3 \& B.4=Native habitat), and spring (C.1=Gorse habitat). Letters on movement paths correspond to day-fixes every $48 \mathrm{hrs}$ in summer and autumn, and every $24 \mathrm{hrs}$ in spring.

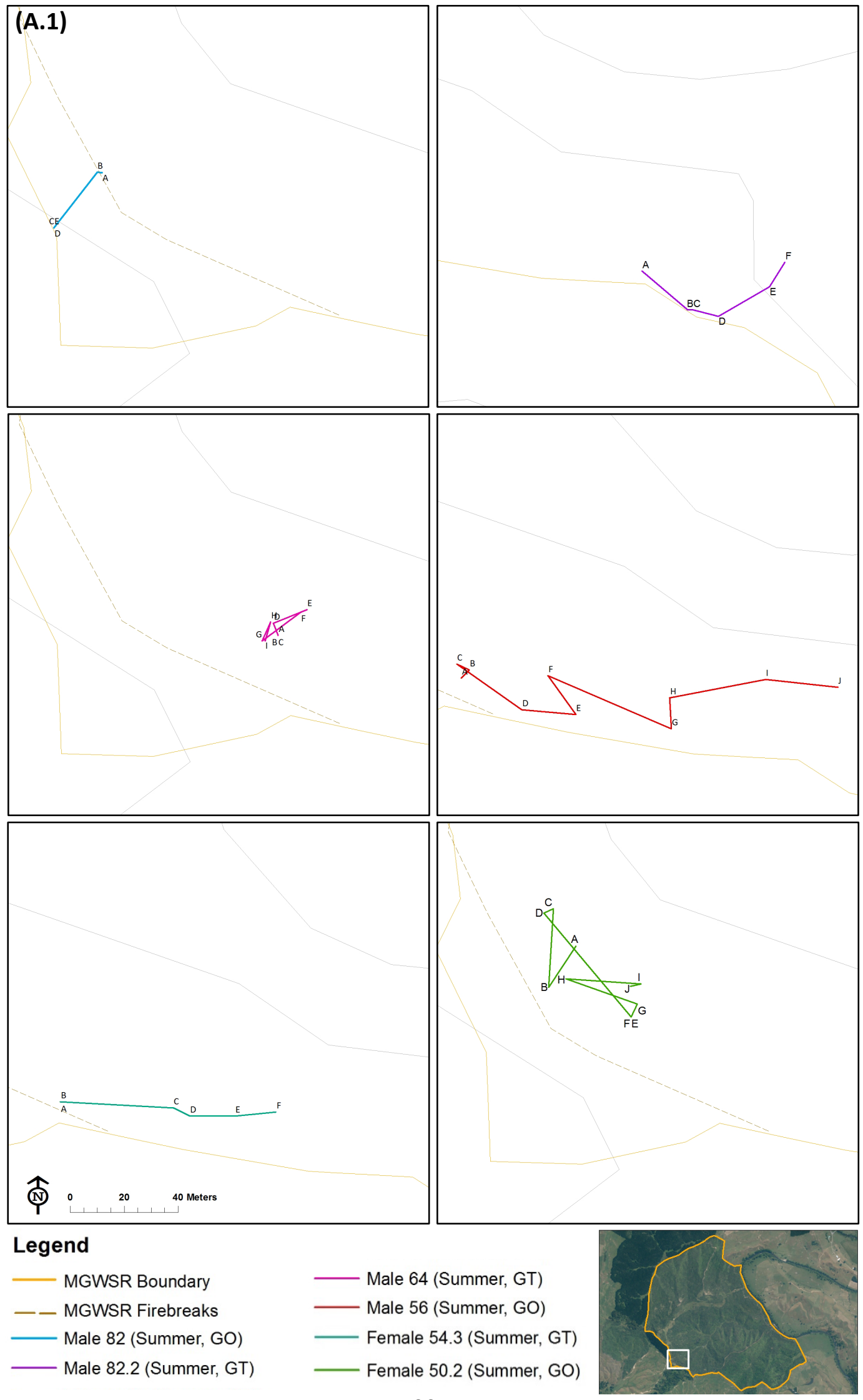




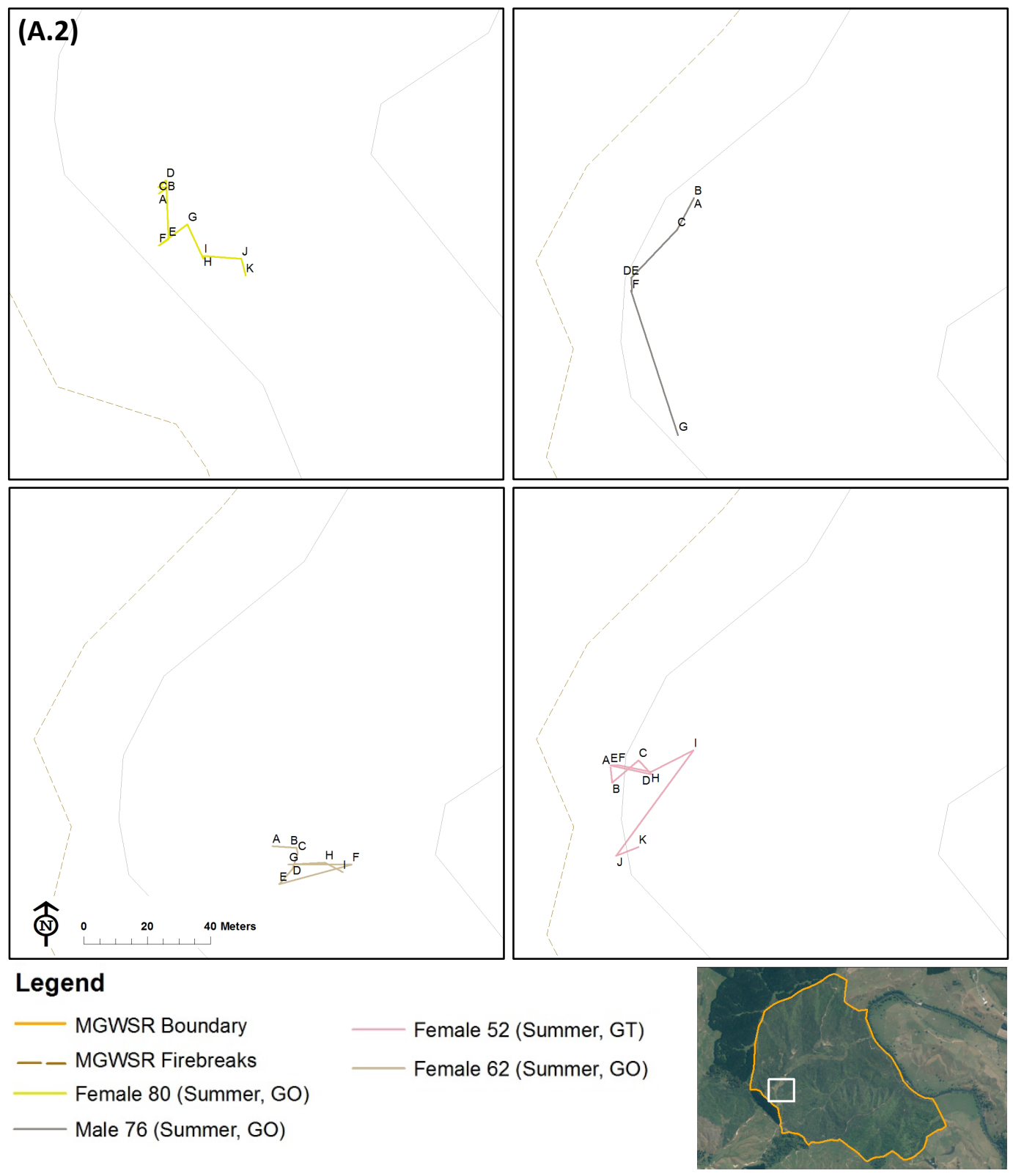




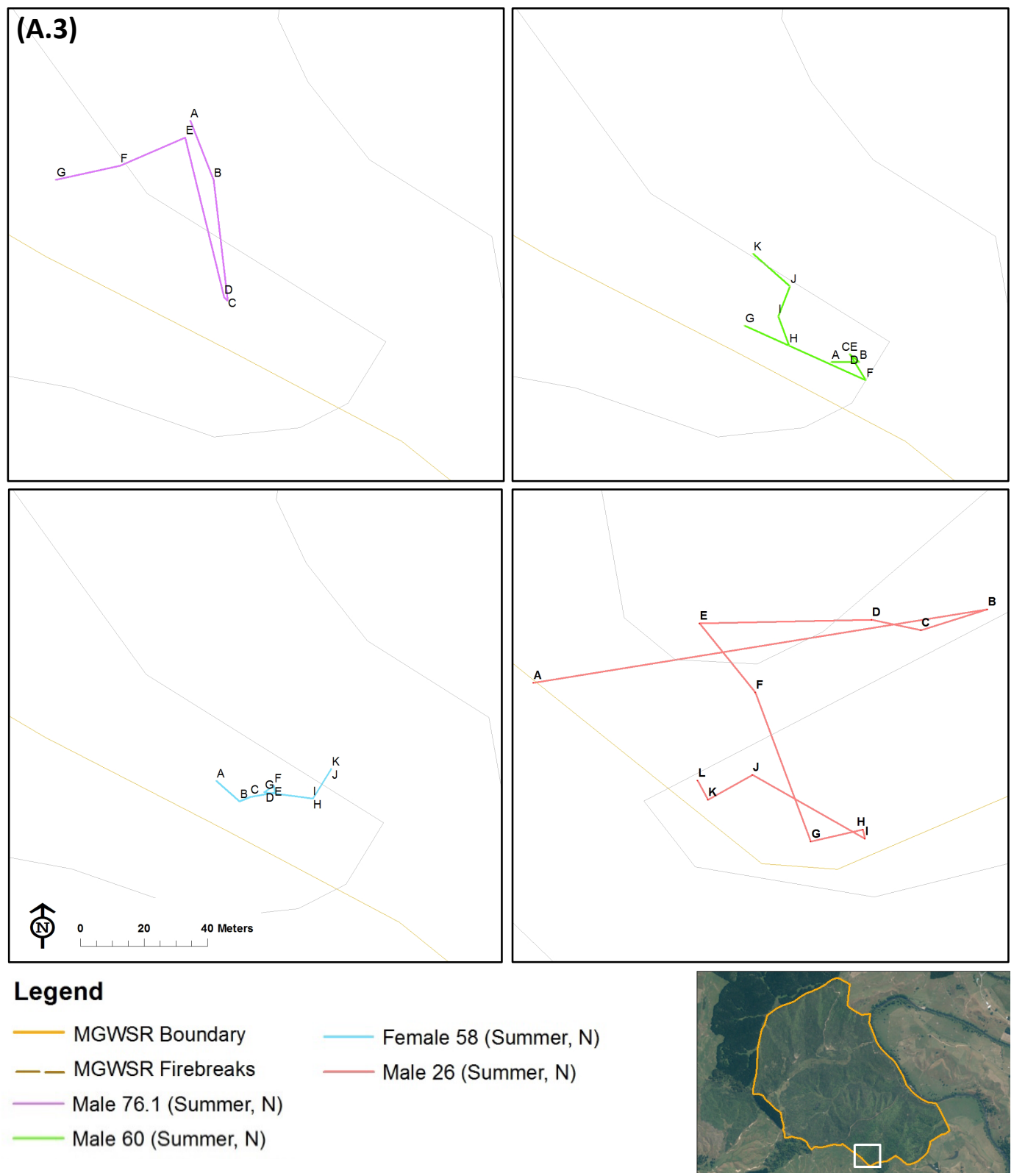



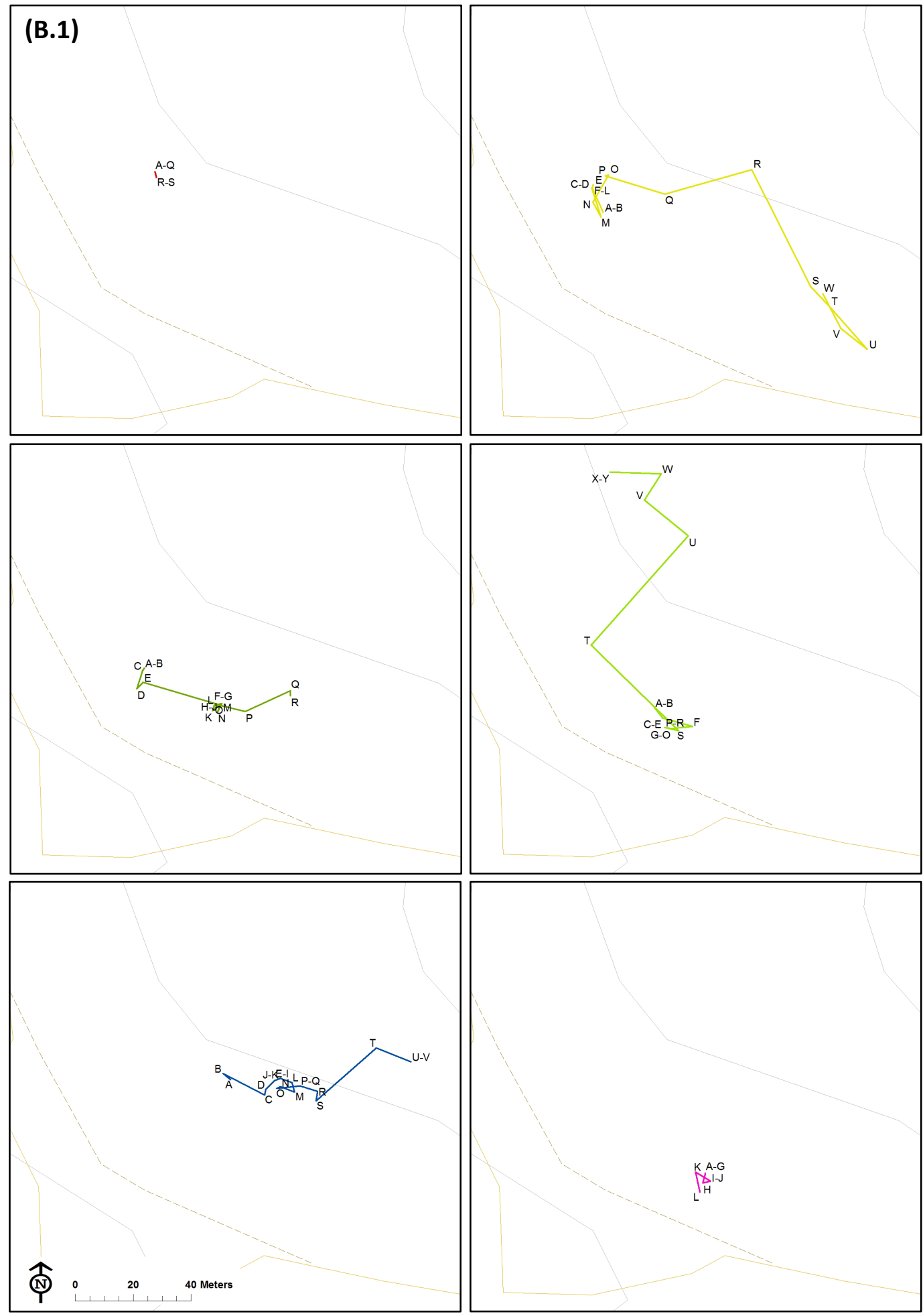

\section{Legend}
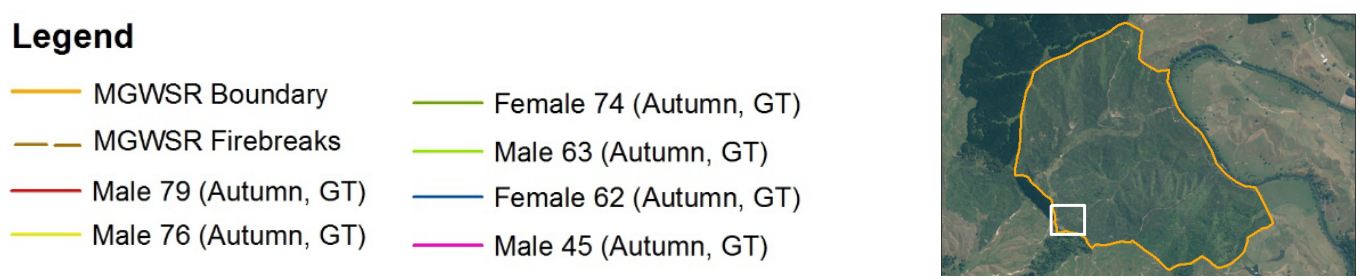


\section{(B.2)}

C-D ${ }^{A-B}$

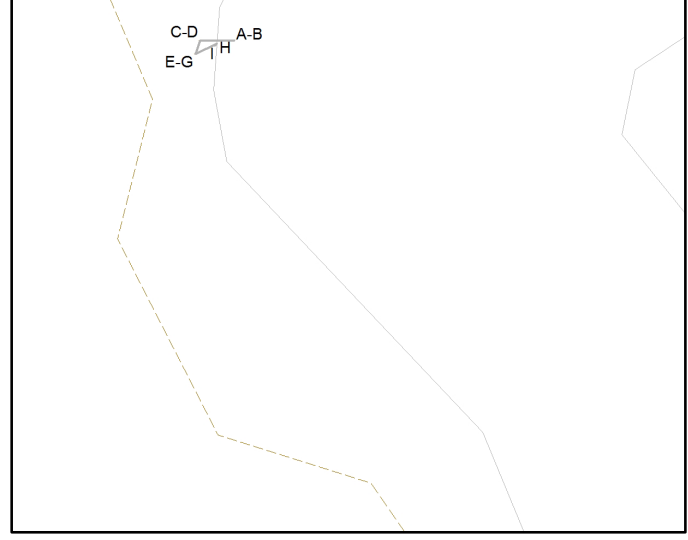

aw
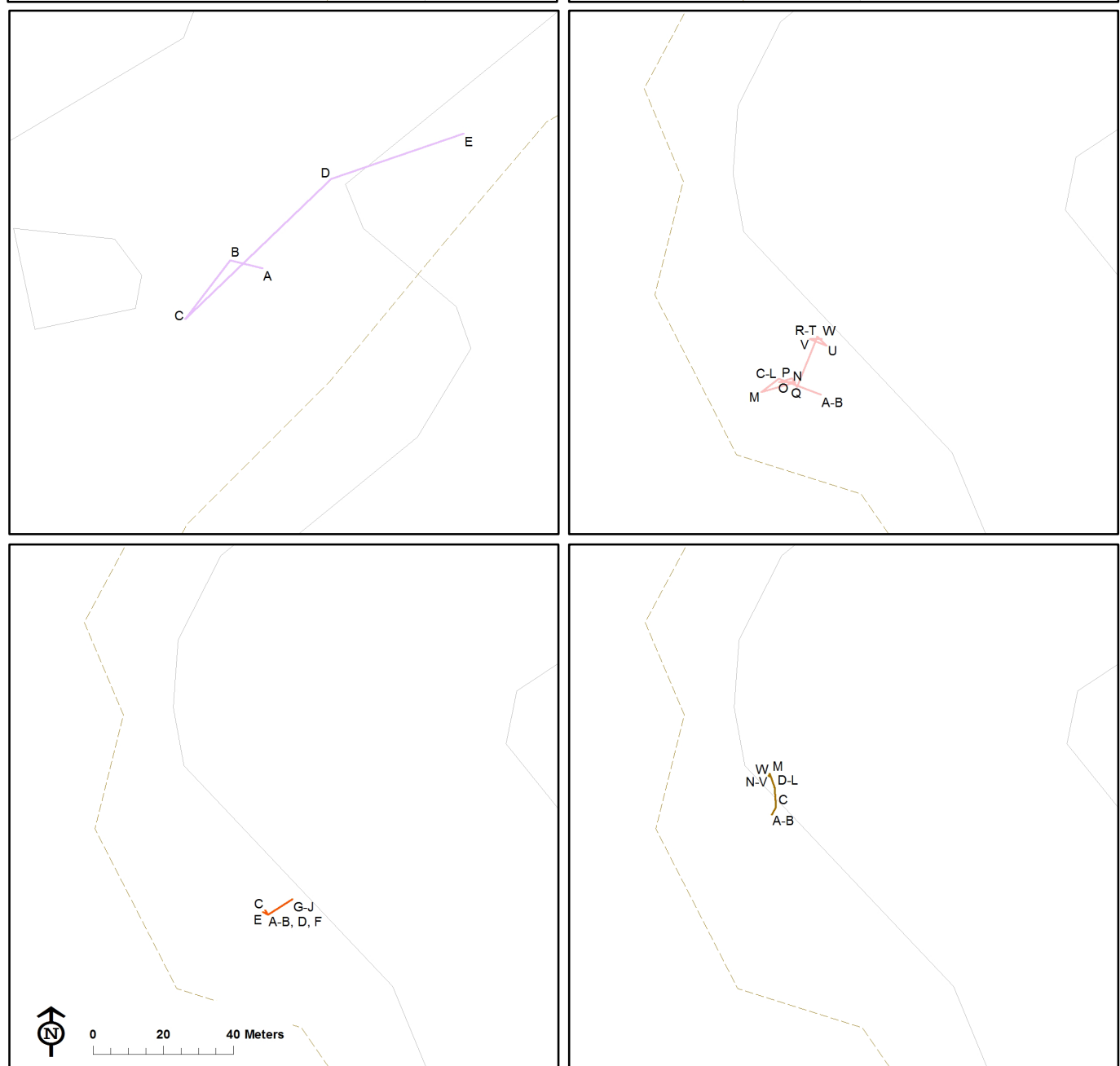

\section{Legend}

- MGWSR Boundary

- - MGWSR Firebreaks

Female 98 (Autumn, G1

Male 72 (Autumn, GO)

Male 70 (Autumn, GO)

Female 67 (Autumn, GO)

Female 66 (Autumn, GO)

Female 64 (Autumn, GO)

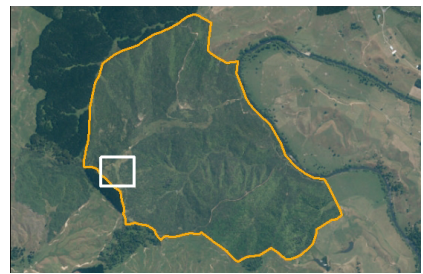




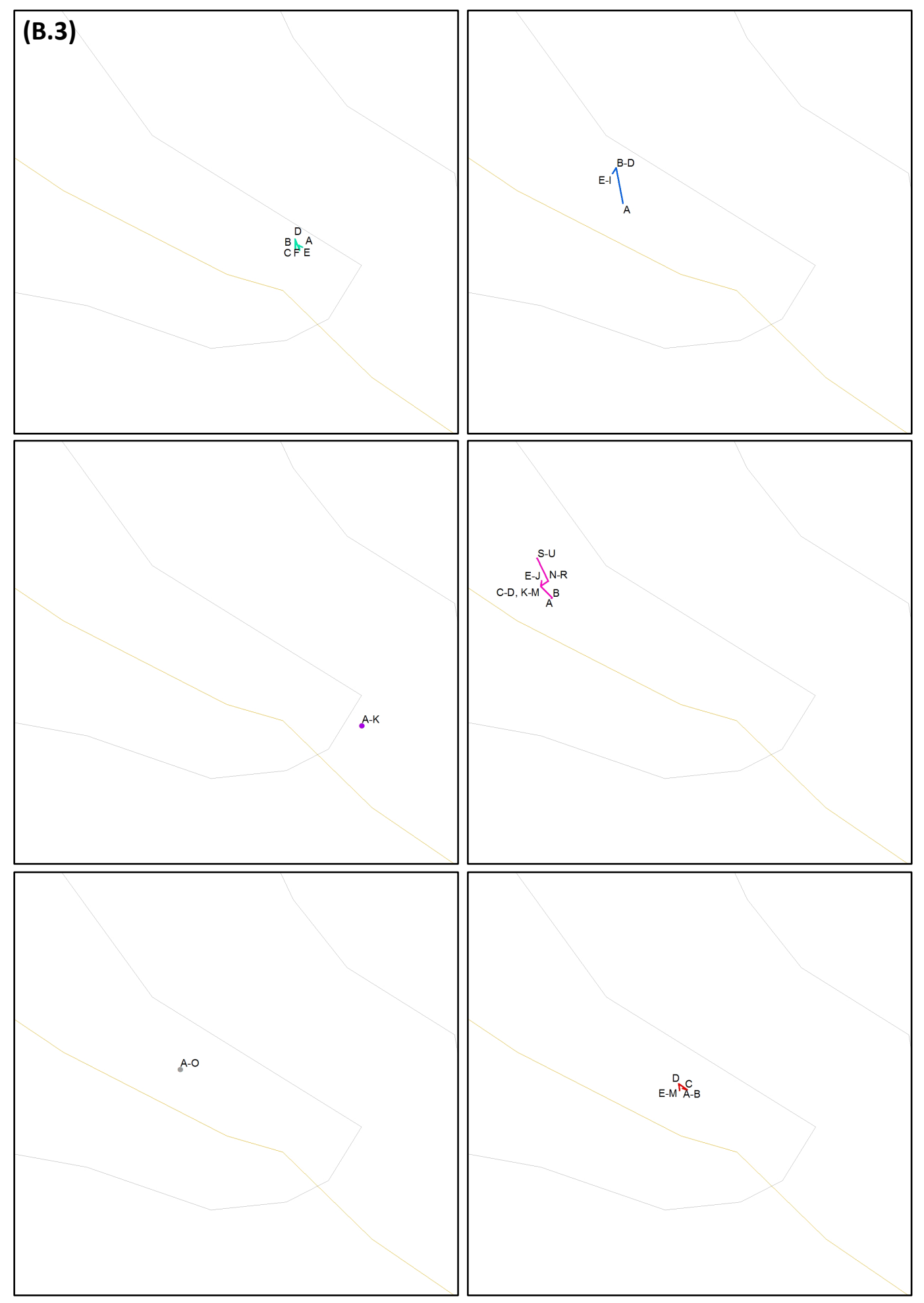

95 


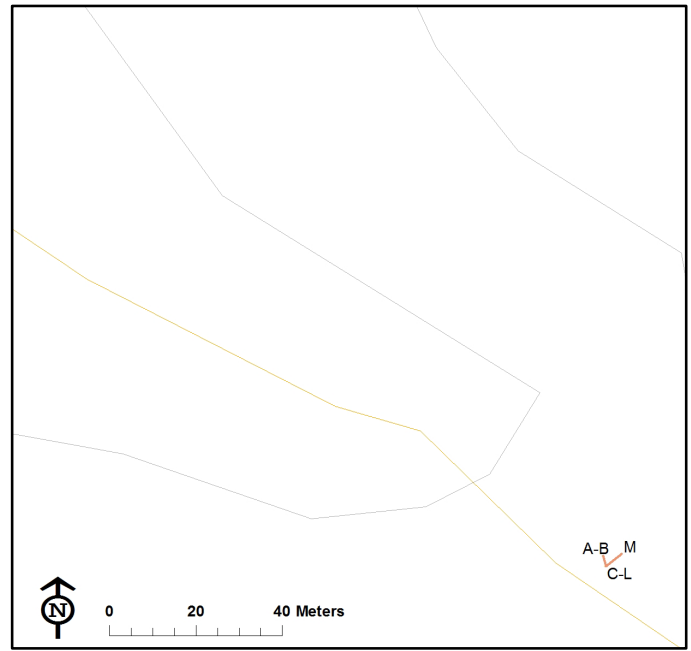

\section{Legend}

\begin{tabular}{cc}
- MGWSR Boundary & Female 68 (Autumn, N) \\
- MGWSR Firebreaks & - Female 61 (Autumn, N) \\
- Male 73 (Autumn, N) & Male 42 (Autumn, N) \\
\hline Male 71 (Autumn, N) & Female 09 (Autumn, N)
\end{tabular}

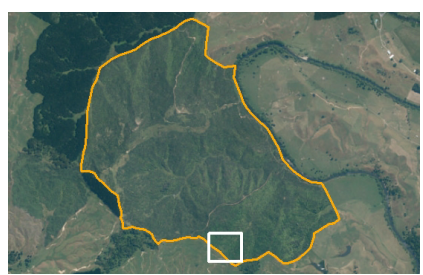




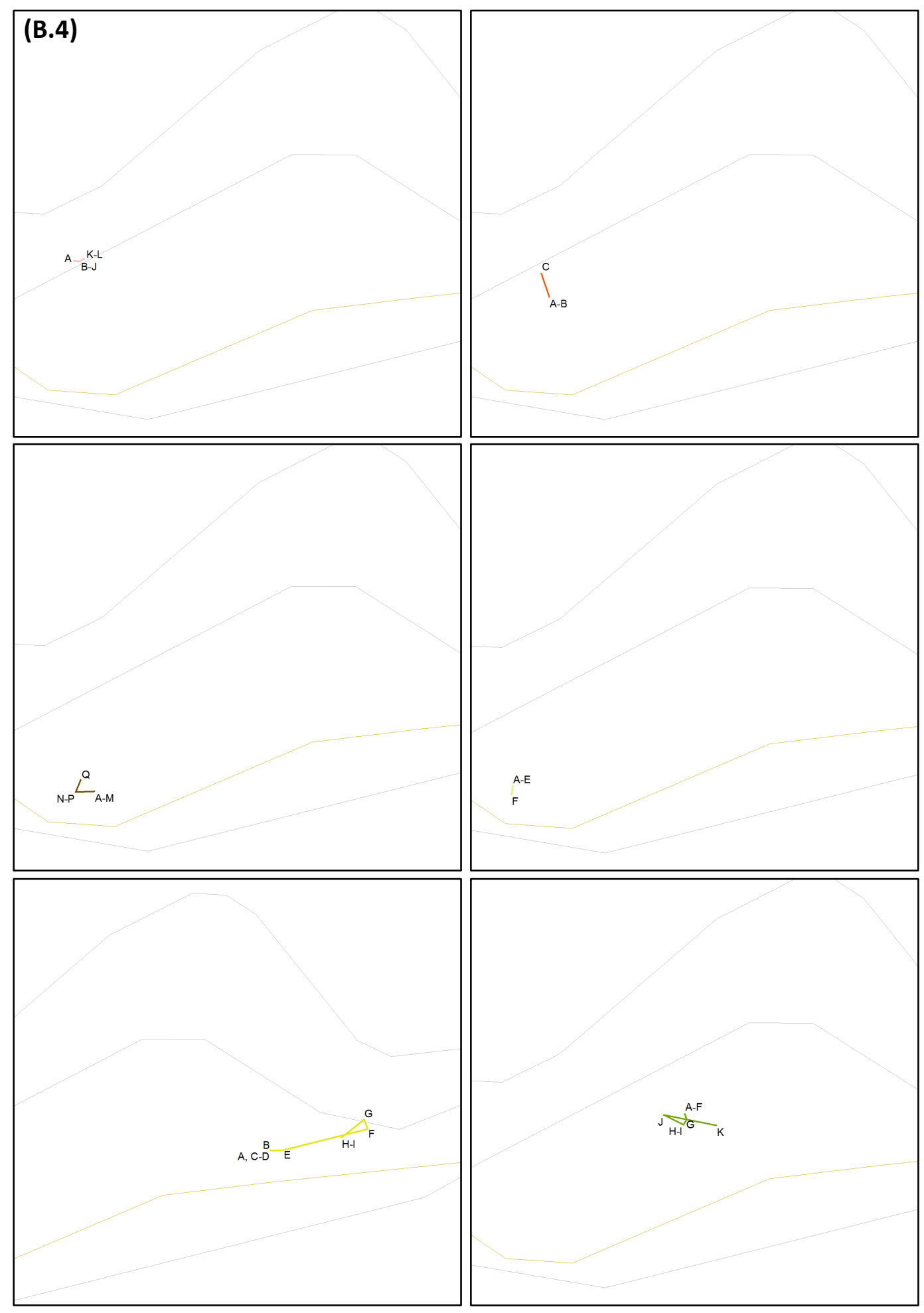

97 

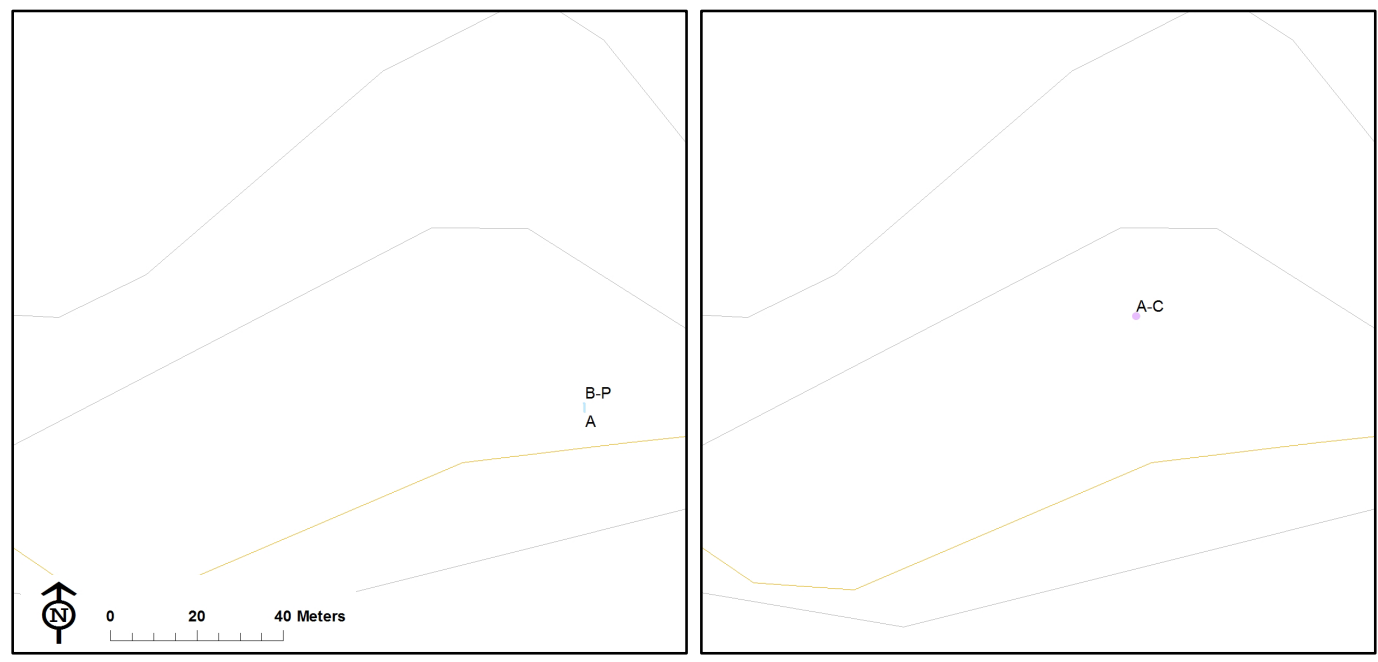

Legend

$\begin{array}{cc}- \text { MGWSR Boundary } & \text { Female } 75 \text { (Autumn, N) } \\ - \text { MGWSR Firebreaks } & \text { Male } 41 \text { (Autumn, N) } \\ - \text { Male } 80 \text { (Autumn, N) } & \text { Female } 40 \text { (Autumn, N) } \\ - \text { Male } 78 \text { (Autumn, N) } & \text { Male } 38 \text { (Autumn, N) } \\ \text { Male } 77 \text { (Autumn, N) } & \text { Male } 37 \text { (Autumn, N) }\end{array}$

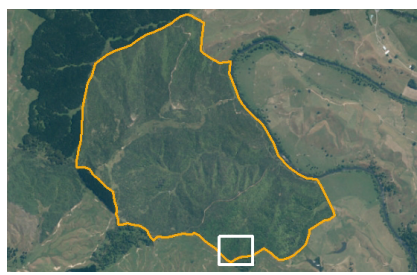




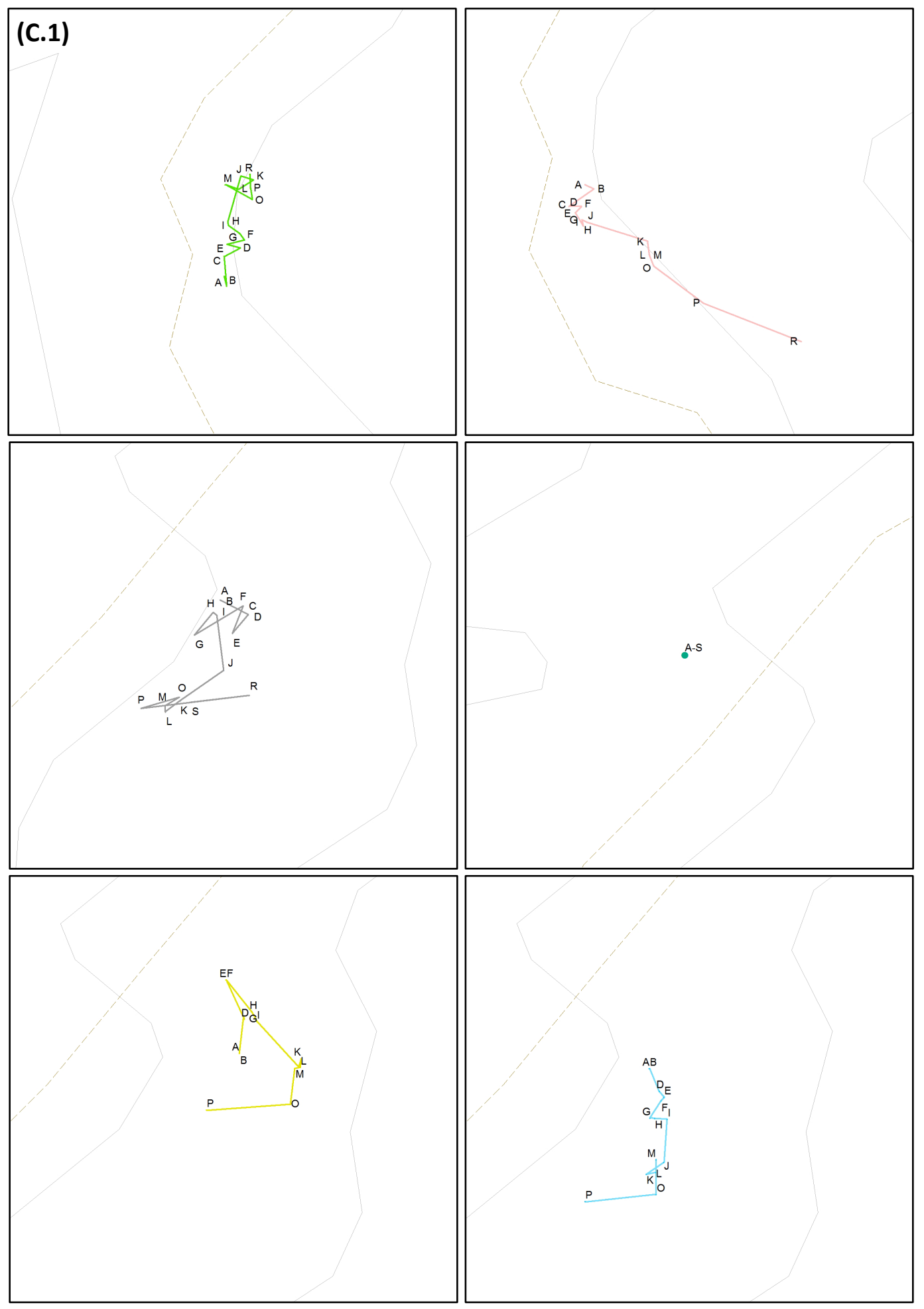




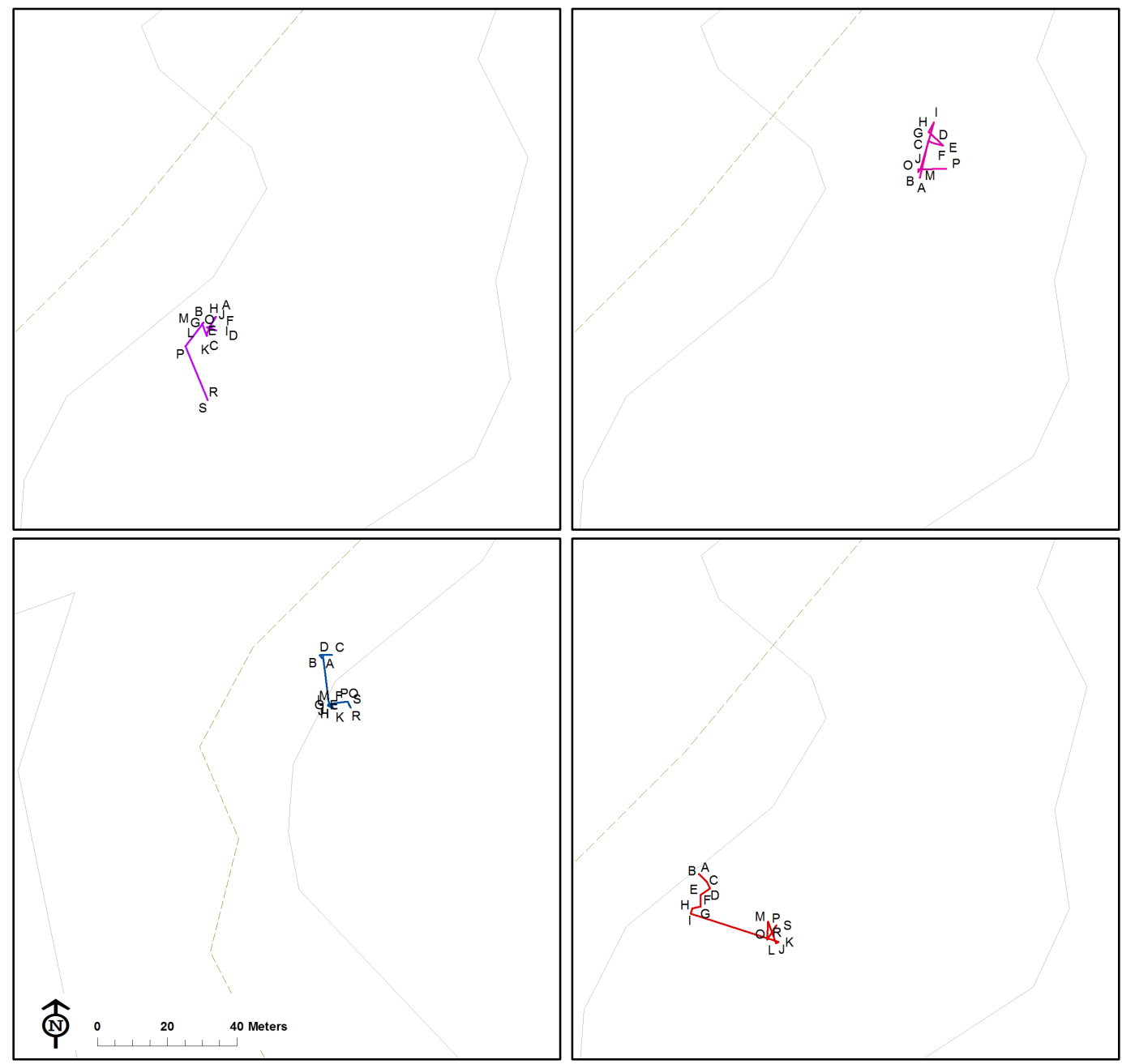

\section{Legend}

$\begin{array}{ll}- \text { MGWSR Boundary } & \text { Male } 85 \text { (Spring, GO) } \\ - \text { MGWSR Firebreaks } & \text { Female } 84 \text { (Spring, GO) } \\ - \text { Female } 94 \text { (Spring, GT) } & \text { - Female } 78 \text { (Spring, GT) } \\ \text { Male } 92 \text { (Spring, GT) } & \text { Female } 77 \text { (Spring, GO) } \\ \text { Male } 90 \text { (Spring, GO) } & \text { - Female 47 (Spring, GT) } \\ \text { Male } 88 \text { (Spring, GO) } & - \text { Male 44 (Spring, GT) }\end{array}$

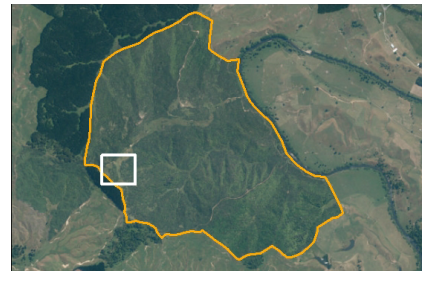





\section{Chapter 4 - Stomach contents of potential mammalian predators of Mahoenui giant wētā (Deinacrida mahoenui)}

\subsection{Abstract}

The last remaining individuals of the original Mahoenui giant wētā (Deinacrida mahoenui) population are currently restricted to an 187ha mainland reserve in Mahoenui, western King Country, New Zealand. Having sought refuge in the introduced woody shrub, gorse (Ulex europaeus), these wētā have survived in the presence of introduced mammalian predators for almost 6 decades. However, due to natural succession, the reserve is gradually reverting to native bush and wētā monitoring data shows potential signs of population decline. Concerns for the species survival have been raised as it is unknown how wētā will cope in an altered habitat alongside mammalian predators. We attempted to identify potential mammalian predators of the MGW by analysing the stomach contents of ship rats (Rattus rattus), house mice (Mus musculus), brushtail possums (Trichosurus vulpecula), and feral cats (Felis catus). Stomach contents analysis revealed ship rats as probable predators of MGW, with 9 of 10 analysed stomachs containing wētā (unknown species) remains. Although we could not visually determine whether these remains belonged to MGW or another species (e.g. tree, cave or ground wētā), if rats are preying upon other species of wētā in the MGWSR, they are also likely predating MGW. One mouse stomach (of 10) also contained wētā remains, but no remains were found in either possum $(n=6)$ or cat $(n=2)$ stomachs. We recommend further analysis be done to obtain a larger and more comprehensive sample size in order to obtain more robust results. Furthermore, we suggest a mammalian control plan be implemented that targets all mammalian species to avoid the competitive or predatory release of another species. 


\subsection{Introduction}

New Zealand invertebrates evolved in a unique environment where mammalian pests were absent up until the early $13^{\text {th }}$ century (Daugherty et al., 1993; Worthy et al., 2006; Wilmshurst et al., 2008), and as a result, gigantism, flightlessness, and ground-dwelling traits are common (Gibbs, 1998; Watts et al., 2014). Behavioural anti-predator adaptations, such as crypsis, evolved, suited to evade native visual and auditory predators (Gibbs, 2010). The arrival of mammalian predators, three species of rat (Rattus spp.), house mouse (Mus musculus), brushtail possum (Trichosurus vulpecula), and feral cat (Felis catus), with keen olfactory senses led to the extinction, extirpation, and suppression of many naïve and vulnerable invertebrate species. For example, introduced mammals were found to have caused range suppression of beetles Mimopeus elongatus and Ctenognathus novaezealandiae on some of the Noises Islands (Watt, 1983), and the decline of terrestrial flax snail Placostylus hongii on Motuhoropapa Island (Moors, 1985). The extinction of the large-bodied weevil Hadramphus stilbocarpae from Big South Cape Island (Kuschel \& Worthy, 1996) and endemic land snails Amborhytida tarangensis and Placostylus hongii from Lady Alice Island (Brook, 1999) have also been attributed to rodents.

Wētā (Anostostomatidae and Rhaphidophoridae) have had variable survival success in the presence of mammalian predators. Tree wētā (Hemideina spp.) are still relatively common on the mainland and are considered somewhat 'pre-adapted' to olfactory hunters by inhabiting small, inaccessible natural galleries (Gibbs, 2009; Watts et al., 2017b). Likewise, alpine wētā (Deinacrida and Hemideina spp.) are able to survive on the mainland due to inhabiting altitudes above where mammalian pests have penetrated (Gibbs, 1998). The much larger lowland giant wētā (Deinacrida spp.) have not fared as well, with many species now restricted to offshore islands or pest-free areas on the mainland (Gibbs, 1998). The Mahoenui giant wētā (MGW; D. mahoenui) is one of the select few lowland species still naturally present on the mainland, near Mahoenui, western King Country. The species' survival has been attributed to the presence of the introduced woody shrub gorse (Ulex europaeus) that dominates the reserve (Mahoenui Giant Wētā Scientific Reserve; MGWSR; 187ha), which the wētā inhabit (Richards, 1994). The shrub's spiny, dense foliage is thought to provide refuge from mammalian predators and a food source for the wētā (Sherley \& Hayes, 1993; Watts \& Thornburrow, 2009). 
However, due to natural succession, the reserve is gradually reverting to native vegetation (Sullivan et al., 2007). Of the reserves three valleys, the southernmost is already completely dominated by native trees and ferns, and in recent years tree ferns (Dicksonia fibrosa and Cyathea spp.) and ground ferns have become noticeably more present throughout the northern and middle valleys (Quinnell, 2015; DOC, 2016b). This is of concern because native vegetation lacks the protective foliage that gorse provides and may expose wētā to higher rates of predation (Watts \& Thornburrow, 2009). In addition to this, raw annual monitoring data collected by DOC suggests the Mahoenui population may be declining and there is no regular pest control maintained in the MGWSR, except for periodic possum control for bovine tuberculosis (TB) management (Quinnell, 2015).

Concerns for the long-term survival of the MGW have been raised as it is unknown how wētā will cope in native regenerating vegetation alongside mammalian predators. Wētā in general are known to be an important dietary component for many predatory mammalians in New Zealand (Fitzgerald \& Karl, 1979; Rickard, 1996; Wilson et al., 2006; Innes et al., 2010; Bridgman, 2012). Their size, ineffective anti-predator adaptations, and odour make them an easy and highly profitable target when available (Gibbs, 1998; St Clair, 2011). Innes (1977) found wētā remains in $75 \%$ of all ship rat ( $R$. rattus) stomachs and identified wētā as the most frequently consumed food item across seasons in the Manawatu, and Wilson et al. (2006) recorded wētā in $36 \%$ of mice stomachs in both alpine and forest habitats. European hedgehogs (Erinaceus europaeus) have been found to consume large numbers of wētā, with 283 legs indicating at least 47 wētā found in one stomach (Jones et al., 2005). Tree wētā, ground wētā, and cave wētā remains were identified in $20 \%$ of stoat (Mustela erminea) stomachs (Murphy et al., 2008).

The unique situation of the MGW means there is little knowledge on predation by mammalian pests in a gorse dominated environment. There are only four recorded accounts of MGW predation by ship rat, hedgehog, possum, and harrier hawk (Jowett \& Plant, 1988; Jowett, 1991). In order to have the greatest benefit for MGW from pest management, it is important to understand the diet of mammals present in the MGWSR. There are numerous techniques that can be used to assess diet: faecal analysis (Cowan \& Moeed, 1987; Molsher et al., 1999), direct field observation (McConkey et al., 2003), captive-feeding trials (Richards, 1994; Shiels, 2011), stable isotope analysis (Shiels et al., 2013) DNA analysis (Egeter et al., 2015; Kartzinel 
\& Pringle, 2015), or stomach contents analysis (Daniel, 1973; Rickard, 1996; Watts, 2001; McQueen \& Lawrence, 2008). Stomach contents analysis is a practical method commonly used for terrestrial mammals that provides relatively precise results. Alternative methods can be costly to run and may result in unnatural or limited data (Klare et al., 2011; Egeter et al., 2015).

In this study, we assessed the diet of four introduced mammalian pest species (ship rat, house mouse, brushtail possum, and feral cat) at the MGWSR using stomach contents analysis. Our results allowed us to identify predators of MGW and provide recommendations for future pest management operations.

\subsection{Methods}

\subsubsection{Study site}

Refer to Chapter 2.

\subsubsection{Mammal trapping}

Trapping of ship rats and house mice was conducted over six nights in autumn (March) and 12 nights in winter (July - August) 2018 (animal ethics (VUW AEC 0000025062) and DOC (60994-FAU) approval granted). Six single-set DOC 200 kill traps containing a single mousetrap were set during both trapping periods (Fig. 4.2). Twenty modified Victor traps in tunnels containing a single mousetrap and two double-set DOC 200 kill traps were additionally set during winter. Traps were placed approximately 50 -100m apart along the edges of northern and middle firebreaks among gorse and native vegetation, and baited with peanut butter and eggs or peanut butter and Erayze (dried rabbit meat lure) in autumn and winter, respectively. Brushtail possum and feral cat carcasses were provided from leghold and live-capture trapping completed by a Maniapoto DOC staff member within the MGWSR during winter. All traps were located more than $300 \mathrm{~m}$ from radiotracking sites (Chapter 3) to minimise influencing local predator populations and therefore survival results. Traps were checked daily, reset and rebaited if required. 
Animals caught were identified to species, measured (head-body length, tail length, and weight), sexed, aged (juvenile or adult) and given an individual identification number. Stomachs were removed by dissection on the day of capture and stored in $100 \%$ ethanol until needed for analysis.

\subsubsection{Stomach contents analysis}

Mammal stomach contents were analysed under a dissecting microscope. Frequency of occurrence (FOO) and visually estimated relative occurrence (RO) were used to quantify results (Hansson, 1970; Watts, 2001). FOO is the frequency at which food items are present in the stomachs of a single species. The result is given as a percentage of the total number of full stomachs analysed (Hansson, 1970). RO is the visual percentage estimate of the food items in a single stomach averaged over all stomachs of a single species (Hansson, 1970). For simplicity, contents were split into six categories: plant material, invertebrate, bait (Erayze or peanut butter), avian, mammal/fur, and other/unidentifiable material. Invertebrate remains were further identified to the lowest possible classification level with the assistance of Corinne Watts and other Manaaki Whenua - Landcare Research staff. Stomachs were excluded from analysis if they were empty or had parasitic worms that made up more than half of the contents volume (Innes, 1977). Only a subset of collected stomachs were analysed due to the time-consuming nature of the analysis. 

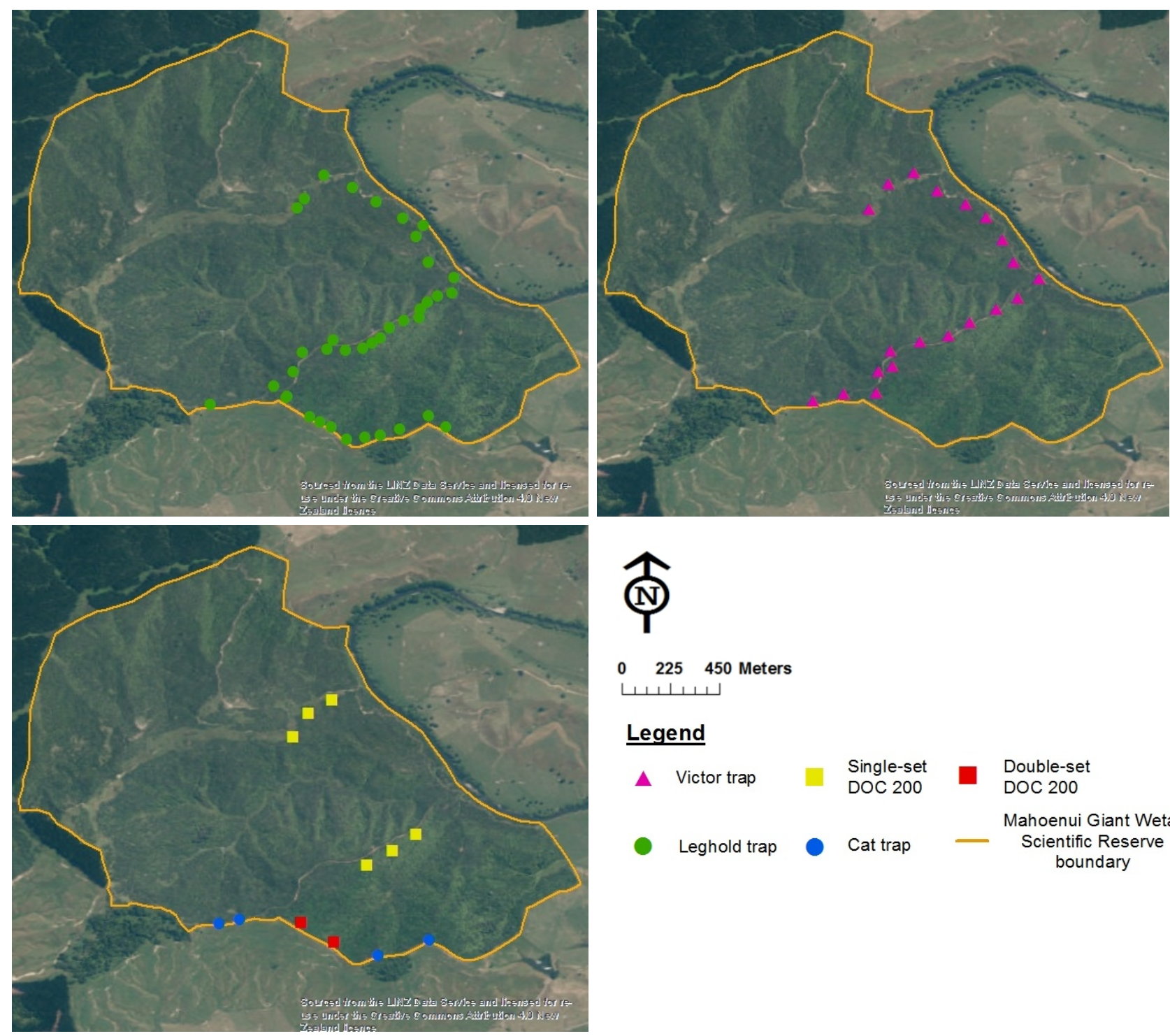

Legend

$\begin{array}{lll}\text { Victor trap } \square \begin{array}{l}\text { Single-set } \\ \text { DOC 200 }\end{array} & \begin{array}{l}\text { Double-set } \\ \text { DOC 200 } \\ \text { Mahoenui Giant Weta } \\ \text { Scientific Reserve }\end{array}\end{array}$ boundary

Figure 4.2 Trap locations within the MGWSR. The northernmost and middle valleys are gorse dominated and the southernmost valley is dominated by native vegetation. Only single-set DOC 200 traps containing a single mousetrap were set in autumn 2018. All traps (Victor, single-set DOC 200, double-set DOC 200, leghold, and cat traps) were set in winter 2018. Leghold and cat traps were serviced by a DOC staff member.

\subsubsection{Data Analysis of trap catch rates}

A generalised linear mixed-effects model with binomial distribution was used to assess the effects of season and habitat on rat, mice, and possum trap catch rates. Cats were not assessed due to only three being trapped. As repeated measures were taken from individual traps, the variable 'trap' was specified as a random effect. All statistical analysis was 
completed in R version 3.5.1 (R Core Team, 2018), using package Ime4 (Bates et al., 2015). Pvalues were considered significant when $\alpha<0.05$ (95\% confidence).

\subsection{Results}

\subsubsection{Species' catch distribution}

A total of 30 ship rats and 37 mice were caught over the 18 nights traps were set (Appendix 4.1 and 4.2). Twenty-one possums and three feral cats were trapped and provided by DOC (Appendix 4.1 and 4.2). When accounting for the number of traps set at any particular time, there was no significant difference found for species catches between habitats (Rat $z=0.485$, $p=0.628$; Mice $z=-1.301, p=0.193 ;$ Possum $z=0.823, p=0.41 ;$ Table 4.1). However, season had a significant effect with approximately five-times more rats and mice, per number of traps set, being caught in autumn than winter (Rats $z=-2.590, p=0.01$; Mice $z=-3.614, p<0.001$ : Fig. $4.3)$.

Table 4.1 Summary of proportion of DOC, Victor and leghold traps for rats and mouse traps for mice set in autumn and winter 2018 that caught mammalian pests. Traps were serviced daily. The number of trap nights within each season and habitat is given by $n$.

\begin{tabular}{|c|c|c|c|}
\hline \multirow[b]{2}{*}{ Season } & \multirow[b]{2}{*}{ Habitat } & \multicolumn{2}{|c|}{ Proportion of catches per traps } \\
\hline & & Ship rat & House mouse \\
\hline \multirow{2}{*}{ Autumn } & Gorse & $0.06(n=18)$ & $0.44(n=18)$ \\
\hline & Native & $0.39(n=18)$ & $0.17(n=18)$ \\
\hline \multirow{2}{*}{ Winter } & Gorse & $0.04(n=271)$ & $0.09(n=240)$ \\
\hline & Native & $0.05(n=148)$ & $0.09(n=72)$ \\
\hline
\end{tabular}




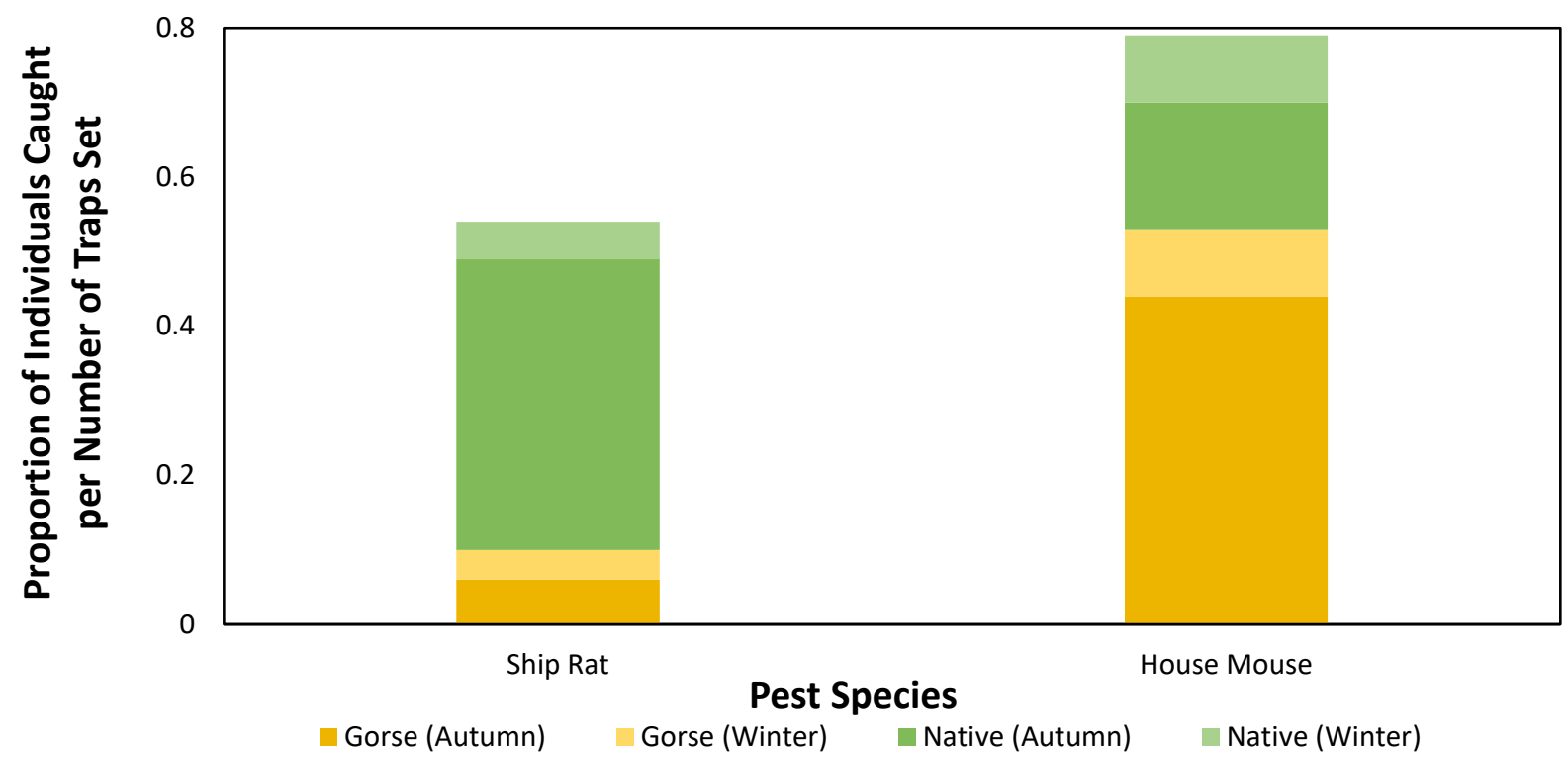

Figure 4.3 Proportion of ship rats and house mice trapped in the Mahoenui Giant Wētā Scientific Reserve as a function of trapping effort. Catches are separated into gorse (yellow) and native (green) habitats and autumn (dark shades) and winter (dull shades) seasons.

\subsubsection{Feral cats}

Three cat stomachs were examined, one was empty and not considered for further analysis. All cats were caught in native habitat. Both of the full stomachs contained plant material and mammal/fur. Avian remains were found in one stomach. No invertebrates were found (Table 4.2). Mammal/fur made up approximately $50 \%$ of stomach contents volume. Plant material and avian remains were less important proportionally, making up $22.5 \%$ and $25 \%$ of contents respectively (Table 4.2).

Table 4.2 Summary of visually estimated relative occurrence (RO) for main food items found in two feral cat stomach contents.

\begin{tabular}{lccc}
\hline & \multicolumn{2}{c}{ RO percentage } & $\begin{array}{c}\text { Average RO } \\
\text { percentage }\end{array}$ \\
\cline { 2 - 3 } Food categories & Cat \#41 & Cat \#24 & \\
\hline Plant material & $5 \%$ & $40 \%$ & $22.5 \%$ \\
Invertebrate & $0 \%$ & $0 \%$ & $0 \%$ \\
Bait & $0 \%$ & $0 \%$ & $0 \%$ \\
Mammal/Fur & $95 \%$ & $5 \%$ & $50 \%$ \\
Avian & $0 \%$ & $50 \%$ & $25 \%$ \\
Other & $0 \%$ & $5 \%$ & $2.5 \%$ \\
\hline
\end{tabular}




\subsubsection{Brushtail possums}

A total of five full possum stomachs were analysed. Three of the possums were caught in gorse habitat and two in native habitat. All stomachs (100\%) contained plant material and fur. Invertebrate and avian remains were present in $80 \%$ and $20 \%$ of stomachs respectively (Table 4.3). Mites (60\%) were the most common invertebrate found, followed by weevils ( $40 \%$; Table 4.4). Plant material was determined to be an important dietary component, comprising $74 \%$ of stomach contents on average (Table 4.3).

Table 4.3 Summary of frequency of occurrence (FOO) and visually estimated relative occurrence (RO) for main food items found in brushtail possum stomach contents.

\begin{tabular}{lccc}
\hline Food categories & $\begin{array}{c}\text { FOO } \\
\text { percentage } \\
(\mathbf{n}=\mathbf{5})\end{array}$ & $\begin{array}{c}\text { Average RO percentage } \\
(\mathbf{n}=\mathbf{5})\end{array}$ & $\begin{array}{c}\text { Range of } \\
\text { values }\end{array}$ \\
\hline Plant material & $100 \%$ & $73.8 \%$ & $45-98 \%$ \\
Invertebrate & $80 \%$ & $2 \%$ & $0-5 \%$ \\
Bait & $0 \%$ & $0 \%$ & $0 \%$ \\
Mammal/Fur & $100 \%$ & $19.2 \%$ & $2-50 \%$ \\
Avian & $20 \%$ & $0.2 \%$ & $0-1 \%$ \\
Other & $20 \%$ & $4.8 \%$ & $0-24 \%$ \\
\hline
\end{tabular}

Table 4.4 Summary of frequency of occurrence (FOO) for invertebrates found in brushtail possum stomach contents.

\begin{tabular}{lc}
\hline Invertebrate & $\begin{array}{c}\text { FOO percentage } \\
\text { ( } \mathbf{n}=\mathbf{5})\end{array}$ \\
\hline Mites (Arachnida) & $60 \%$ \\
Weevils (Coleoptera) & $40 \%$ \\
Beetles (Coleoptera) & $20 \%$ \\
Springtail (Collembola) & $20 \%$ \\
Ant (Hymenoptera) & $20 \%$ \\
Woodlouse (Isopoda) & $20 \%$ \\
Pseudoscorpion (Pseudoscorpiones) & $20 \%$ \\
Unknown larvae & $20 \%$ \\
\hline
\end{tabular}

\subsubsection{Ship Rats}

A total of ten full rat stomachs were analysed. Four rats were caught in gorse habitat during winter, one in native habitat during autumn, and five in native habitat during winter. All 
stomachs contained plant material and invertebrates (100\%; Table 4.5). Wētā (unknown species) were the most common invertebrate consumed ( $90 \%$ of stomachs). Mites, spiders, and beetles were also important invertebrate food items occurring in $70 \%, 60 \%$ and $60 \%$ of stomachs respectively (Table 4.6). Additionally, one MGW egg was found. Sixty percent of rat stomachs also contained parasitic nematodes, with an average of five $( \pm 1.8)$ nematodes per stomach. None of these were excluded from analysis due to relative volumes being less than or equal to $50 \%$ (Innes, 1997).

Table 4.5 Summary of frequency of occurrence (FOO) and visually estimated relative occurrence (RO) for main food items found in ship rat stomach contents.

\begin{tabular}{lccc}
\hline Food categories & $\begin{array}{c}\text { FOO } \\
\text { percentage } \\
(\mathbf{n = 1 0 )}\end{array}$ & $\begin{array}{c}\text { Average RO } \\
\text { percentage } \\
(\mathbf{n = 1 0 )}\end{array}$ & $\begin{array}{c}\text { Range of } \\
\text { values }\end{array}$ \\
\hline Plant material & $100 \%$ & $39.9 \%$ & $10-77 \%$ \\
Invertebrate & $100 \%$ & $37.2 \%$ & $5-90 \%$ \\
Bait & $50 \%$ & $11 \%$ & $0-40 \%$ \\
Mammal/Fur & $70 \%$ & $5.1 \%$ & $0-15 \%$ \\
Other & $40 \%$ & $6.8 \%$ & $0-30 \%$ \\
\hline
\end{tabular}

Table 4.6 Summary of frequency of occurrence (FOO) for invertebrates found in ship rat stomach contents.

\begin{tabular}{lc}
\hline Invertebrate & $\begin{array}{c}\text { FOO percentage } \\
\text { (n=10) }\end{array}$ \\
\hline Wētā (Orthoptera) & $90 \%$ \\
Wētā egg & $10 \%$ \\
Mite (Arachnida) & $70 \%$ \\
Spider (Araneae) & $60 \%$ \\
Beetle (Coleoptera) & $60 \%$ \\
Parasitic nematode (Ascaridida) & $60 \%$ \\
Centipede (Chilopoda) & $40 \%$ \\
Caterpillar (Lepidoptera) & $40 \%$ \\
Snail (Gastropoda) & $20 \%$ \\
Aphid/unknown (Hemiptera) & $20 \%$ \\
Thrip (Thysonoptera) & $20 \%$ \\
Fungus gnat (Diptera) & $10 \%$ \\
Earthworm (Oligochaeta) & $10 \%$ \\
Unknown & $40 \%$ \\
\hline
\end{tabular}




\subsubsection{House mice}

A total of ten full stomachs were analysed. Three mice were caught in gorse habitat in autumn, five in gorse habitat during winter and two in native habitat during winter. All stomachs contained invertebrate remains, with spiders ( $90 \%$ of stomachs) and caterpillars ( $90 \%$ of stomachs) found to be the primary dietary items (Table 4.7 and 4.8 ). Plant material was less important for mice, being found in only $50 \%$ of stomachs. Proportionally, invertebrates consumption represented on average $50 \%$ of stomach contents. Peanut butter bait was also largely consumed (35.2\%; Table 4.7$)$.

Table 4.7 Summary of frequency of occurrence (FOO) and visually estimated relative occurrence (RO) for main food items found in house mouse stomach contents.

\begin{tabular}{lccc}
\hline Food categories & $\begin{array}{c}\text { FOO } \\
\text { percentage } \\
(\mathbf{n = 1 0 )}\end{array}$ & $\begin{array}{c}\text { Average RO } \\
\text { percentage } \\
(\mathbf{n = 1 0 )}\end{array}$ & $\begin{array}{c}\text { Range of } \\
\text { values }\end{array}$ \\
\hline Plant material & $50 \%$ & $3.6 \%$ & $0-17 \%$ \\
Invertebrate & $100 \%$ & $50.5 \%$ & $8-100 \%$ \\
Bait & $60 \%$ & $35.2 \%$ & $0-92 \%$ \\
Mammal/Fur & $10 \%$ & $0.5 \%$ & $0-5 \%$ \\
Other & $20 \%$ & $10.2 \%$ & $0-72 \%$ \\
\hline
\end{tabular}

Table 4.8 Summary of frequency of occurrence (FOO) for invertebrates found in house mouse stomach contents.

\begin{tabular}{lc}
\hline Invertebrate & $\begin{array}{c}\text { FOO percentage } \\
(\mathbf{n = 1 0 )}\end{array}$ \\
\hline Spider (Araneae) & $90 \%$ \\
Caterpillar (Lepidoptera) & $90 \%$ \\
Unknown Hymenoptera & $20 \%$ \\
Mite (Arachnida) & $10 \%$ \\
Centipede (Chilopoda) & $10 \%$ \\
Wētā (Orthoptera) & $10 \%$ \\
\hline
\end{tabular}




\subsection{Discussion}

Introduced mammalian pests are known to have a large impact on invertebrate populations across New Zealand. However, it is equally important to understand the impact of individual species in a specific environment. The lack of pest control, except for irregular possum control, in the MGWSR and pest monitoring results (see Chapter 2) suggest there is an abundance of rats, mice, and possums present for most of the year (Quinnell, 2015; DOC, 2016a). Our catch rates consistently show rats and mice are more abundant in autumn compared to winter. Mammalian pest populations usually peak around late summer and autumn due to spring/summer breeding and the abundance of food leading into autumn (Cowan, 2005; Innes, 2005; Ruscoe \& Murphy, 2005). As only eight traps were set during autumn, it is unlikely trapping depleted rat and mice stocks enough to cause lower catch rates during winter. Habitat appears to have no effect on catch rate, indicating both areas, native vegetation and gorse, are utilised by mammals to a similar degree. However, numerous traps were placed near the boundary between native and gorse habitats, which could have resulted in habitat crossover by animals providing a misleading result. No hedgehogs or mustelids (Mustela spp.) were caught during trapping, but it is recommended that the diet of these species in the MGWSR are assessed as both are known to regularly consume invertebrates including wētā (Jones et al., 2005; Murphy et al., 2008; Jones et al., 2013).

Stomach contents analysis is one of the more practical and precise methods for analysing animal diets. However, there are associated disadvantages. Stomach contents at the time of trapping provides only a snapshot of food items eaten (Inger \& Bearhop, 2008). Therefore, it may appear a species is not an important dietary component if not found. Caution must be taken not to assume this as it may be solely by chance that animals trapped had not eaten that species recently, when in reality they are consumed regularly. In order to obtain robust results using this method, it is recommended to have a large sample size (>100; Jones et al., 2005) as well as sampling over multiple seasons (Inger \& Bearhop, 2008). Despite the small sample sizes presented in this study ( $n=2-10)$, our results for brushtail possums, ship rats, and house mice appear to concur with published literature. However, we recommend further analysis be done to obtain a larger and more comprehensive sample size in order to obtain robust results. 
Despite these shortcomings, analysing stomach contents allowed us to identify common food items of mammalian pests in the MGWSR. The two cat stomachs analysed did not contain wētā or any invertebrates, but the sample size is in the results. Feral cats will prey on small mammals, birds, reptiles, and invertebrates and can vary their diets seasonally depending on prey species availability (Bonnaud et al., 2011). Invertebrates are not often the dominant food item consumed by cats, but are frequently consumed at an approximate rate of $0.34 \mathrm{~g}$ per hectare per night (Innes et al., 2010). This is especially true for invertebrates belonging to orders containing larger-bodied species such as Orthoptera, Lepidoptera, or Coleoptera (Medina \& Garcia, 2007). Fitzgerald and Karl (1979) recorded wētā were the most common invertebrate consumed by cats in the Orongorongo Valley (Wellington, New Zealand) and consumption varied by season, with summer and autumn scats containing higher volumes of remains. Although we are unable to determine the effect of feral cats on MGW in this study, they should be considered a threat, especially if other food sources such as rats and mice are controlled in MGWSR in the future (Medina \& Garcia, 2007).

Since their introduction to New Zealand, brushtail possums have had a devastating impact on native vegetation. Plant material commonly contributes to the bulk of possum diets (Nugent et al., 2000) and was present in all analysed stomachs in this study. Invertebrates, conversely, comprise a much smaller dietary proportion and many smaller species are thought to be passively consumed with foliage or leaf litter (Rickard, 1996). The invertebrate species' recorded in this study were likely consumed in this way or through grooming. Larger-bodied invertebrates including wētā have been recorded in possum faeces, but the frequency at which they occur suggests they are consumed opportunistically when readily available and easy to obtain (Cowan \& Moeed, 1987; Rickard, 1996). Innes et al. (2010) suggested possums could consume an average weight of $32 \mathrm{~g}$ of invertebrates per hectare per night in the presence of other mammals. MGW may irregularly feature in possum diets due to inaccessibility in gorse, but are likely consumed more frequently during summer and autumn when wētā are spending more time on or near the ground mating and ovipositing. Therefore, controlling possum numbers in summer and autumn may have a positive effect on adult survival and oviposition. Further analysis to obtain a larger sample size is needed to gain a better insight of brushtail possum diets at the MGWSR. 
Ship rats are among the most widespread and destructive of the introduced mammals, especially where invertebrates are concerned (Grant-Hoffman \& Barboza, 2010; Shiels et al., 2014). However, literature gaps remain regarding their impact on some indigenous invertebrate groups (e.g., land snails; (Barker, 2016). Ship rats are generally omnivorous, feeding on a range of plants, fungi, invertebrates and vertebrates, though plant material and larger-bodied invertebrates are usually the most common food items consumed (Daniel, 1973; Innes, 1977; Copson, 1986; Sweetapple \& Nugent, 2007; Innes et al., 2010; Bridgman, 2012; Shiels et al., 2014). The average weight of invertebrates rats can consume per night in the presence of other mammals has been estimated at 39g per hectare per night (Innes et al., 2010). Rats in the MGWSR were found to consume plant material and a range of invertebrates, such as beetles, spiders, centipedes, caterpillars, and wētā, in relatively equal volumes. Wētā were the most import invertebrate consumed, but we were only able to identify the exact species of a few remains by visual assessment. Auckland tree wētā ( $H$. thoracica) and cave wētā (Rhaphidophoridae) were identified on two occasions as well as a MGW egg (Appendix 4.3). Previous studies have similarly identified the importance of wētā in New Zealand rat diets. For example, wētā were found to be the most frequent invertebrate consumed by ship rats (76\% of 176 stomachs) in remnant Manawatu forests (Innes, 1977). Likewise, a literature review by Bridgeman (2012) revealed wētā were a dominant invertebrate food item in most assessed studies. As tree wētā inhabit similar refuges and display similar activity to MGW within the MGWSR (Richards, 1994), predation of these species suggests the much larger and more profitable MGW are just as likely predated. Cave wētā have occasionally been observed in the gorse (C Watts pers. comm., 2018). Management of ship rat populations within the MGWSR is recommended from the preliminary results found in this study and results of others identifying wētā as an important component of rat diets.

Parasitic nematodes (Ascaridida) were found in $60 \%$ of analysed rat stomachs. Endoparasites are commonly found in ship rat stomachs and infection may be due to consumption of invertebrates that provide an intermediate host for the parasite (Daniel, 1973; Miller \& Miller, 1995). Despite some rats in the MGWSR containing large numbers of parasitic nematodes, Innes (1977) and Spratt (1990) have both suggested there is no evidence the parasites hinder host survival. Mites (Arachnida) were also found in $70 \%$ of analysed rat stomachs, but as these 
invertebrates are known ectoparasites of rats (Innes, 1977), it is likely they were accidentally ingested through grooming.

The house mouse is another invasive rodent that is widespread globally, but are difficult to control (Angel et al., 2009). Their effect on invertebrate populations is often hard to depict when other mammalian species are present (Angel et al., 2009; Bridgman, 2012), but mice have been linked to the decline of some invertebrate species (Orthoptera and Coleoptera (Marris, 2000); Lepidoptera (Chown et al., 2002)). Mice are flexibly omnivorous consuming a range of small invertebrates ( $3-12 \mathrm{~mm}$ long) and plant material (Ruscoe \& Murphy, 2005; Watts et al., 2017a). Innes et al. (2010) estimated mice to consume approximately 9g of invertebrates per hectare per night in the presence of other mammals. In the MGWSR, mice appear to be predominantly insectivorous, consuming a larger volume of invertebrates, namely Lepidopteran larvae and spiders (Aranaea), than plant material. This result is consistent with numerous studies from New Zealand (Badan, 1986; Fitzgerald et al., 1996; Miller \& Webb, 2001; Watts, 2001; Wilson et al., 2006; Bridgman, 2012) and overseas (Copson, 1986; Angel et al., 2009), where Lepidoptera and Aranaea contributed largely to house mice diets. Wētā and beetles were additionally reported as regularly consumed by mice. Adult MGW (>35mm long) may be considered too large for mice to predate (Ruscoe \& Murphy, 2005; Watts et al., 2017a), but juveniles and eggs ( $7 \mathrm{~mm}$ long) are well within range (Richards, 1994). MGW oviposit their eggs in soft wood or soil, leaving them vulnerable to be dug up by mice with a keen sense of smell (Sherley \& Hayes, 1993; Dent, 2016). MGW eggs have not previously been recorded in mouse diets, however, eggs from other wētā species have (Watts, 2001), suggesting it is possible for mice to be impacting the early life stages of MGW.

Although ship rats may target larger invertebrates than mice, the two species do exhibit some dietary overlap (Miller \& Miller, 1995; Shiels et al., 2013; Bridgman et al., 2018; Appendix 4.4). This is important to consider when implementing pest management plans as control of one species could lead to the predatory or competitive release of another (Bridgman et al., 2018). If rat control is conducted in the MGWSR it may result in an irruption in mice numbers (Witmer et al., 2007) which could be detrimental to the juvenile MGW and eggs (Watts, 2001; Watts et al., 2017a). Mice alone have been found to suppress local populations and reduce the average size of invertebrates, including wētā, when at high densities within Sanctuary 
Mountain Maungatautari (Watts et al., 2017a). This caution of controlling specific pest species also applies to feral cats and mustelids which prey on rats and mice frequently (Fitzgerald \& Karl, 1979; Rickard, 1996; Murphy et al., 2008), and may switch prey species when rodent food sources are depleted (Smith \& Jamieson, 2003; Medina \& Garcia, 2007) or become numerous when a suppressed prey population irrupts (Witmer et al., 2007).

Invertebrate consumption in many mammalian species also appears to vary seasonally, where the frequency of invertebrates found in stomach contents appears to be higher in summer and autumn (Miller \& Miller, 1995). This coincides with when invertebrates are often more abundant, active, and mating, which is true for MGW. If year-round pest control is not possible, we suggest targeting all mammalian pests annually before these crucial periods (summer and autumn) in order to improve the number of MGW adults surviving, mating, and ovipositing (Innes et al., 1995; Byrom et al., 2016).

Pest management within the MGWSR has been minimal to date. Despite our shortcomings in providing robust identification of MGW predators, we recommend a long-term broad spectrum pest management plan is implemented within the reserve (see Chapter 5). Rodents, in particular, have been implicated in the decline or extinction of many large-bodied invertebrate species (St Clair, 2011), and are likely negatively affecting MGW. A reduction in mammalian pest numbers may therefore be crucial to preventing further decline of this giant wētā population. 


\subsection{Appendices}

Appendix 4.1 Summary of mammalian pests trapped in autumn and winter. Shaded rows indicate subset of animal stomachs analysed. Feral cats and brushtail possums were trapped by a DOC staff member.

\begin{tabular}{|c|c|c|c|c|c|c|c|c|c|}
\hline ID & Season & Species & Sex & $\begin{array}{c}\text { Weight } \\
\text { (g) }\end{array}$ & $\begin{array}{c}H B L \\
(\mathrm{~mm})\end{array}$ & $\begin{array}{c}\text { Tail } \\
\text { (mm) }\end{array}$ & Age & Trap & Habitat \\
\hline 4 & Autumn & Ship rat & $\mathrm{F}$ & 130 & 167 & 201 & $A$ & DOC 1 & $\mathrm{~N}$ \\
\hline 3 & Autumn & Ship rat & $\mathrm{F}$ & 130 & 163 & 214 & $A$ & DOC 2 & $\mathrm{~N}$ \\
\hline 1 & Autumn & Ship rat & $\mathrm{F}$ & 90 & 142 & 186 & $A$ & DOC 3 & $\mathrm{~N}$ \\
\hline 2 & Autumn & Ship rat & $M$ & 28 & 91 & 108 & J & DOC 3 & $\mathrm{~N}$ \\
\hline 6 & Autumn & Ship rat & $M$ & 80 & 134 & 185 & $A$ & DOC 2 & $\mathrm{~N}$ \\
\hline 5 & Autumn & Ship rat & $M$ & 27 & 92 & 113 & J & DOC 3 & $\mathrm{~N}$ \\
\hline 8 & Autumn & Ship rat & $M$ & 30 & 93 & 120 & J & DOC 3 & $\mathrm{~N}$ \\
\hline 9 & Autumn & Ship rat & $M$ & 100 & 160 & 186 & $A$ & DOC 3 & $\mathrm{~N}$ \\
\hline 10 & Autumn & Ship rat & $F$ & 29 & 99 & 116 & J & DOC 3 & $\mathrm{~N}$ \\
\hline 14 & Autumn & Ship rat & $M$ & 67 & 124 & 166 & J & DOC 6 & G \\
\hline 7 & Autumn & House mouse & $M$ & 20 & 82 & 76 & $A$ & DOC 5 & G \\
\hline 11 & Autumn & House mouse & $\mathrm{F}$ & 13.75 & 75 & 75 & $A$ & DOC 4 & G \\
\hline 12 & Autumn & House mouse & $M$ & 20 & 79 & 86 & $A$ & DOC 5 & G \\
\hline 13 & Autumn & House mouse & $M$ & 12.5 & 79 & 74 & $A$ & DOC 6 & G \\
\hline 17 & Autumn & House mouse & $M$ & 15 & 76 & 81 & $A$ & DOC 2 & $\mathrm{~N}$ \\
\hline 16 & Autumn & House mouse & $M$ & 17 & 83 & 76 & $A$ & DOC 4 & G \\
\hline 15 & Autumn & House mouse & $M$ & 14 & 72 & 71 & $A$ & DOC 5 & G \\
\hline 20 & Autumn & House mouse & $M$ & 17 & 75 & 83 & $A$ & DOC 2 & $\mathrm{~N}$ \\
\hline 21 & Autumn & House mouse & $\mathrm{F}$ & 13 & 71 & 73 & J & DOC 3 & $\mathrm{~N}$ \\
\hline 19 & Autumn & House mouse & $\mathrm{F}$ & 14 & 73 & 73 & $A$ & DOC 5 & G \\
\hline 18 & Autumn & House mouse & $M$ & 17.5 & 85 & 81 & $A$ & DOC 6 & G \\
\hline 83 & Winter & Ship rat & $\mathrm{F}$ & 108 & 151 & 183 & $A$ & DOC 3 & $\mathrm{~N}$ \\
\hline 50 & Winter & Ship rat & $M$ & 78 & 124 & 169 & $A$ & DOC 5 & G \\
\hline 63 & Winter & Ship rat & $M$ & 119 & 166 & 183 & $A$ & DOC 3 & $\mathrm{~N}$ \\
\hline 75 & Winter & Ship rat & $\mathrm{F}$ & 114 & 150 & 200 & $A$ & Vic 20 & G \\
\hline 87 & Winter & Ship rat & $M$ & 109 & 159 & 200 & $A$ & DOC 3 & $\mathrm{~N}$ \\
\hline 78 & Winter & Ship rat & $M$ & 147.5 & 173 & 188 & $A$ & DOC 1 & $\mathrm{~N}$ \\
\hline 74 & Winter & Ship rat & $M$ & 128.5 & 166 & 181 & $A$ & DOC 3 & $\mathrm{~N}$ \\
\hline 86 & Winter & Ship rat & $\mathrm{F}$ & 130 & 157 & 207 & $A$ & Vic 24 & G \\
\hline 65 & Winter & Ship rat & $\mathrm{F}$ & 118.5 & 162 & 197 & $A$ & LH 11 & G \\
\hline 43 & Winter & Ship rat & $M$ & 148.5 & 148 & 186 & $A$ & Vic 25 & G \\
\hline 61 & Winter & Ship rat & $\mathrm{F}$ & 107.5 & 140 & 190 & $A$ & LH12 & $\mathrm{N}$ \\
\hline
\end{tabular}




\begin{tabular}{|c|c|c|c|c|c|c|c|c|c|}
\hline 79 & Winter & Ship rat & $M$ & 109 & 149 & 190 & $A$ & DOC 1 & $\mathrm{~N}$ \\
\hline 76 & Winter & Ship rat & M & 179 & 187 & 206 & $A$ & DOC 4 & G \\
\hline 85 & Winter & Ship rat & $M$ & 109 & 158 & 178 & $A$ & Vic 20 & G \\
\hline 100 & Winter & Ship rat & $\mathrm{F}$ & 78 & 124 & 158 & $J$ & Vic 25 & G \\
\hline 101 & Winter & Ship rat & $\mathrm{F}$ & 118 & 140 & 179 & A & Vic 26 & G \\
\hline 68 & Winter & Ship rat & $M$ & 149 & 170 & 200 & $A$ & Vic 9 & $\mathrm{~N}$ \\
\hline 67 & Winter & Ship rat & $M$ & 136 & 164 & 177 & $A$ & Vic 21 & G \\
\hline 47 & Winter & Ship rat & M & 168.5 & 171 & 203 & $A$ & Vic 26 & G \\
\hline 42 & Winter & Ship rat & $M$ & 160 & 168 & 203 & $A$ & LH 40 & $\mathrm{~N}$ \\
\hline 71 & Winter & House mouse & $F$ & 10 & 60 & 71 & J & DOC 1 & $\mathrm{~N}$ \\
\hline 54 & Winter & House mouse & $\mathrm{F}$ & 15.5 & 81 & 76 & A & DOC 4 & G \\
\hline 44 & Winter & House mouse & $\mathrm{F}$ & 16.5 & 82 & 87 & A & DOC 6 & G \\
\hline 62 & Winter & House mouse & $M$ & 17.25 & 75 & 79 & A & DOC 6 & G \\
\hline 59 & Winter & House mouse & M & 11.5 & 64 & 67 & J & Vic 8 & G \\
\hline 45 & Winter & House mouse & M & 15 & 71 & 76 & J & Vic 19 & G \\
\hline 81 & Winter & House mouse & $\mathrm{F}$ & 14.25 & 77 & 82 & $A$ & Vic 23 & G \\
\hline 88 & Winter & House mouse & $M$ & 16.5 & 72 & 82 & $A$ & Vic 25 & G \\
\hline 49 & Winter & House mouse & M & 16.75 & 71 & 72 & A & DOC 3 & $\mathrm{~N}$ \\
\hline 51 & Winter & House mouse & $M$ & 13.5 & 67 & 82 & $J$ & Vic 17 & $\mathrm{~N}$ \\
\hline 89 & Winter & House mouse & $M$ & 18.5 & 80 & 85.5 & A & Vic 23 & G \\
\hline 77 & Winter & House mouse & M & 16 & 83 & 83 & $A$ & Vic 25 & G \\
\hline 90 & Winter & House mouse & $\mathrm{F}$ & 12.25 & 71 & 75 & $A$ & Vic 13 & G \\
\hline 82 & Winter & House mouse & $M$ & 18.25 & 79 & 81 & A & DOC 6 & G \\
\hline 69 & Winter & House mouse & $\mathrm{F}$ & 13 & 64 & 73 & J & Vic 8 & G \\
\hline 58 & Winter & House mouse & M & 17.75 & 78 & 90 & $A$ & Vic 20 & G \\
\hline 60 & Winter & House mouse & M & 19.5 & 81 & 87 & $A$ & DOC 6 & G \\
\hline 91 & Winter & House mouse & M & 17.75 & 73 & 79 & $A$ & Vic 8 & G \\
\hline 80 & Winter & House mouse & $\mathrm{F}$ & 14.75 & 79 & 75 & $A$ & DOC 6 & G \\
\hline 84 & Winter & House mouse & $\mathrm{F}$ & 9 & 63 & 63 & J & Vic 8 & G \\
\hline 52 & Winter & House mouse & $\mathrm{F}$ & 13.5 & 80 & 74 & $A$ & Vic 13 & G \\
\hline 73 & Winter & House mouse & M & 17 & 83 & 82 & $A$ & Vic 24 & G \\
\hline 53 & Winter & House mouse & M & 17 & 75 & 81 & $A$ & Vic 24 & G \\
\hline 57 & Winter & House mouse & $M$ & 14.5 & 76 & 67 & $A$ & Vic 13 & G \\
\hline 55 & Winter & House mouse & $M$ & 17.5 & 77 & 86 & A & Vic 17 & $\mathrm{~N}$ \\
\hline 46 & Winter & House mouse & M & 19 & 81 & 78 & $A$ & Vic 19 & G \\
\hline 23 & Winter & Brushtail possum & M & 1760 & 395 & 311 & A & LH 10 & $\mathrm{~N}$ \\
\hline 39 & Winter & Brushtail possum & M & 2540 & 445 & 325 & A & LH 13 & G \\
\hline 36 & Winter & Brushtail possum & $\mathrm{F}$ & 2940 & 440 & 371 & A & LH 19 & $\mathrm{~N}$ \\
\hline 35 & Winter & Brushtail possum & $\mathrm{F}$ & 2500 & 480 & 350 & $A$ & LH 21 & $\mathrm{~N}$ \\
\hline
\end{tabular}




\begin{tabular}{|c|c|c|c|c|c|c|c|c|c|}
\hline 37 & Winter & Brushtail possum & $M$ & 3280 & 495 & 367 & $A$ & LH 25 & G \\
\hline 28 & Winter & Brushtail possum & $\mathrm{F}$ & 2040 & 425 & 319 & $A$ & LH 3 & $\mathrm{~N}$ \\
\hline 25 & Winter & Brushtail possum & $F$ & 2160 & 470 & 338 & $A$ & LH 30 & G \\
\hline 38 & Winter & Brushtail possum & $\mathrm{F}$ & 2910 & 406 & 350 & A & LH 8 & $\mathrm{~N}$ \\
\hline 27 & Winter & Brushtail possum & $F$ & 2390 & 470 & 337 & $A$ & LH 1 & G \\
\hline 31 & Winter & Brushtail possum & $\mathrm{F}$ & 2090 & 435 & 160 & $A$ & LH 11 & G \\
\hline 34 & Winter & Brushtail possum & $M$ & 2120 & 423 & 345 & $A$ & LH 13 & G \\
\hline 29 & Winter & Brushtail possum & M & 2590 & 451 & 320 & A & LH 21 & $\mathrm{~N}$ \\
\hline 22 & Winter & Brushtail possum & $M$ & 2020 & 437 & 370 & $A$ & LH 31 & G \\
\hline 97 & Winter & Brushtail possum & $\mathrm{F}$ & 1590 & 399 & 323 & A & LH 8 & $\mathrm{~N}$ \\
\hline 94 & Winter & Brushtail possum & M & 1850 & 415 & 320 & $A$ & LH 9 & $\mathrm{~N}$ \\
\hline 96 & Winter & Brushtail possum & M & 2810 & 478 & 340 & A & LH 10 & $\mathrm{~N}$ \\
\hline 33 & Winter & Brushtail possum & $M$ & 2160 & 416 & 315 & $A$ & LH 21 & $\mathrm{~N}$ \\
\hline 26 & Winter & Brushtail possum & M & 2340 & 440 & 312 & A & LH 23 & $\mathrm{~N}$ \\
\hline 99 & Winter & Brushtail possum & $\mathrm{F}$ & 2360 & 419 & 310 & $A$ & LH 7 & $\mathrm{~N}$ \\
\hline 30 & Winter & Brushtail possum & M & 1480 & 380 & 305 & A & LH 8 & $\mathrm{~N}$ \\
\hline 98 & Winter & Brushtail possum & $\mathrm{F}$ & 1810 & 429 & 320 & A & LH 9 & $\mathrm{~N}$ \\
\hline 41 & Winter & Feral Cat & $F$ & 3360 & 395 & 230 & $A$ & CT 4 & $\mathrm{~N}$ \\
\hline 24 & Winter & Feral cat & $\mathrm{F}$ & 2610 & 420 & 240 & $A$ & LH 15 & $\mathrm{~N}$ \\
\hline 95 & Winter & Feral cat & $M$ & 3770 & 475 & 300 & $A$ & LH 4 & $\mathrm{~N}$ \\
\hline
\end{tabular}


Appendix 4.2. Trap locations where mammalian pests (ship rats, house mice, brushtail possums and feral cats) were caught in (A) autumn and (B) winter. Single-set DOC 200 traps were the only trap type set in autumn. All trap types were set in winter.

(A)

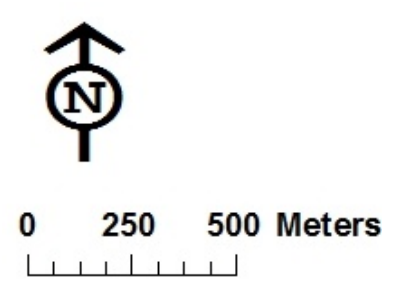

Legend

Single-set
DOC 200
Mouse
Rat
Mahoenui Giant
Weta Scientific
Reserve boundary

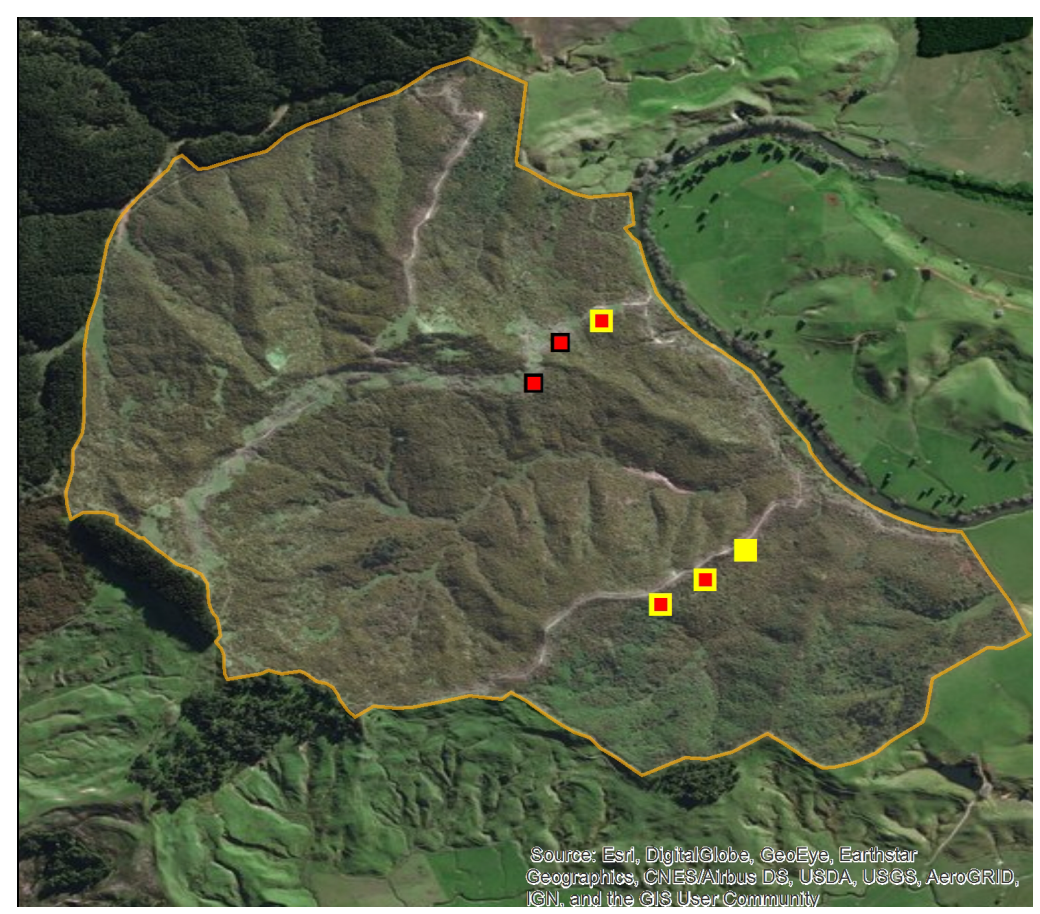



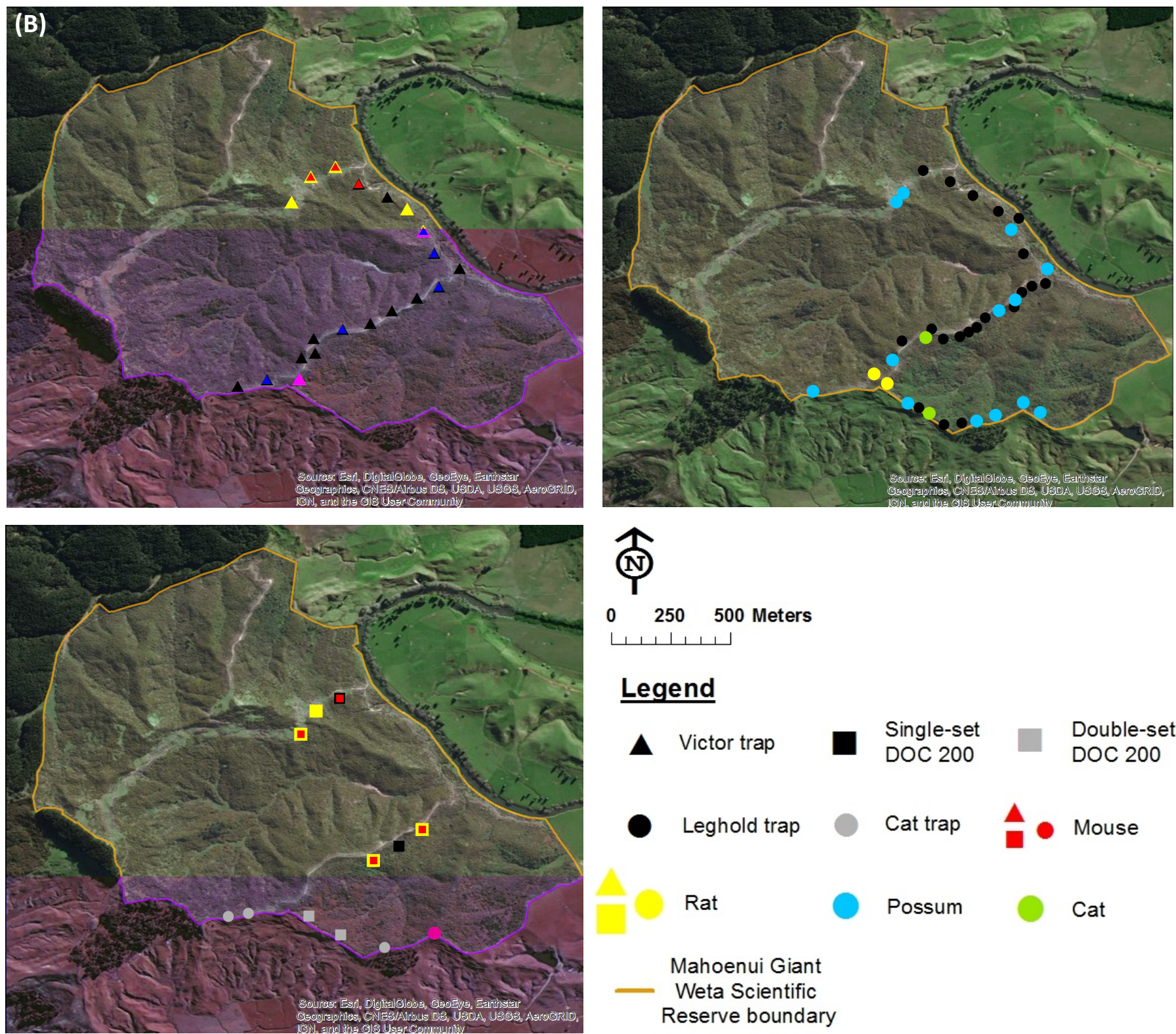

\section{Legend}

$\begin{array}{llll}\mathbf{\Delta} & \text { Victor trap } & \begin{array}{l}\text { Single-set } \\ \text { DOC 200 }\end{array} & \begin{array}{l}\text { Double-set } \\ \text { DOC 200 }\end{array} \\ \text { Rat } & \text { Cat trap } & \text { Possum } & \text { Cat }\end{array}$

Mahoenui Giant

- Weta Scientific Reserve boundary 
Appendix 4.3 Examples of invertebrate remains found in stomach contents. (A) Tree wētā (Hemideina thoracica) exoskeleton; (B) Wētā pronotum; (C) Cave wētā (Rhaphidophoridae) leg tarsus; (D) Wētā leg tarsus; (E) Wētā antennae; (F) Mahoenui giant wētā egg (Deinacrida mahoenui); (G) Caterpillar (Lepidoptera) body, visible spiracles; (H) Spider (Aranaea) leg tarsus and claw; (I) Centipede (Chilopoda) head capsule and body.

(A)
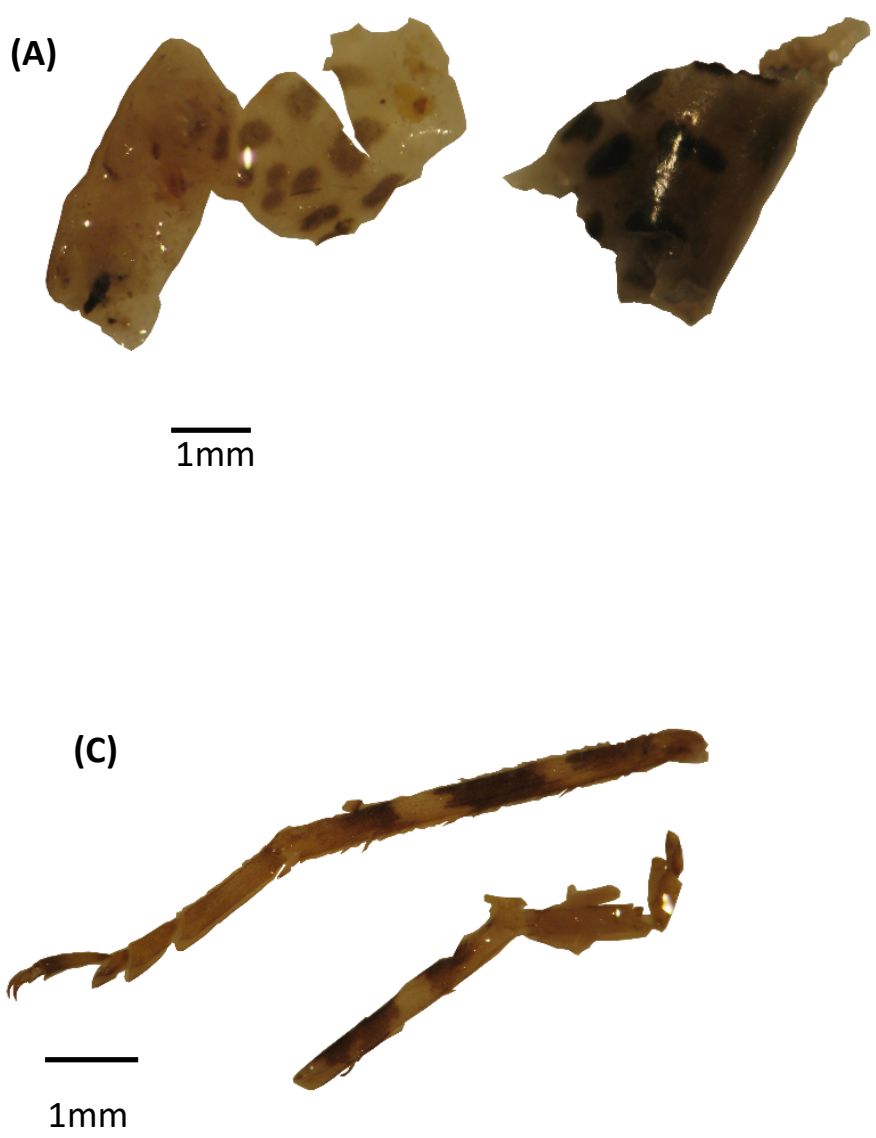

(B)

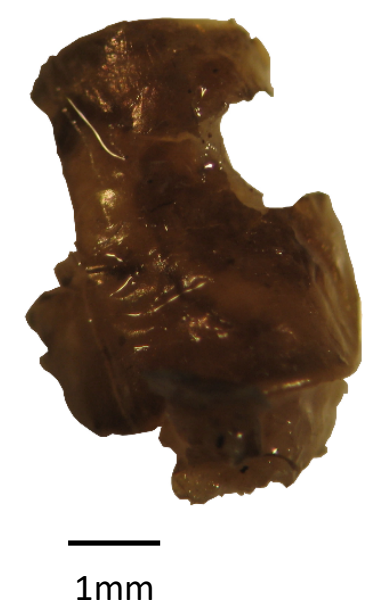

(D)

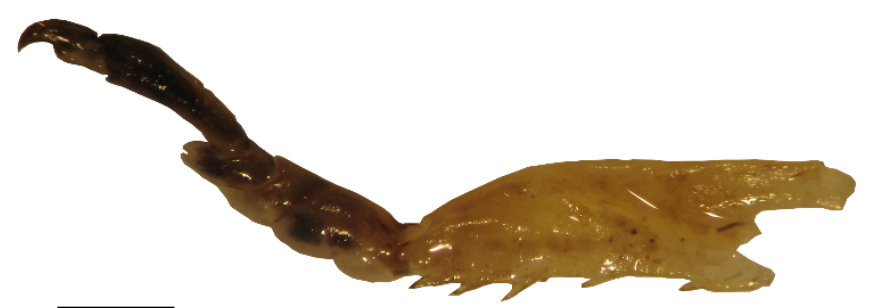

$1 \mathrm{~mm}$

(E)

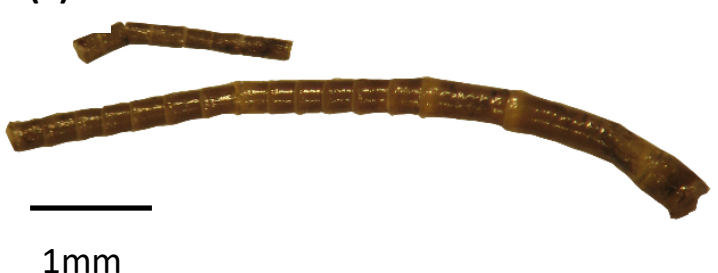


(F)

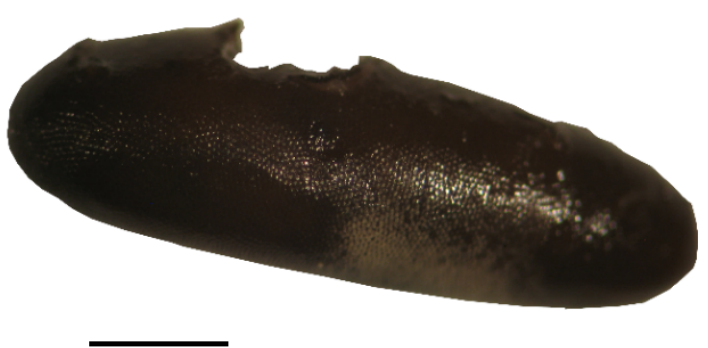

$1 \mathrm{~mm}$

(H)
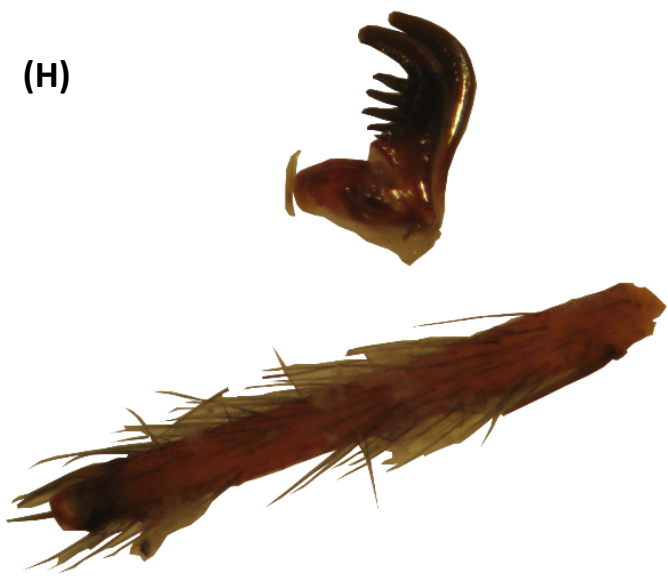

$\overline{1 \mathrm{~mm}}$
(G)

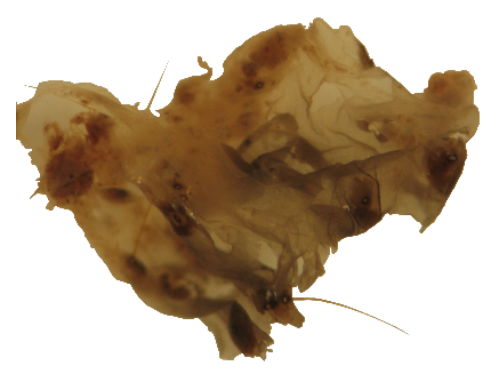

$1 \mathrm{~mm}$

(I)

$1 \mathrm{~mm}$ 
Appendix 4.4 Frequency of occurrence (FOO) for invertebrates found in ship rat (black) and house mice (grey) stomach contents ( $n=10$ for both species).

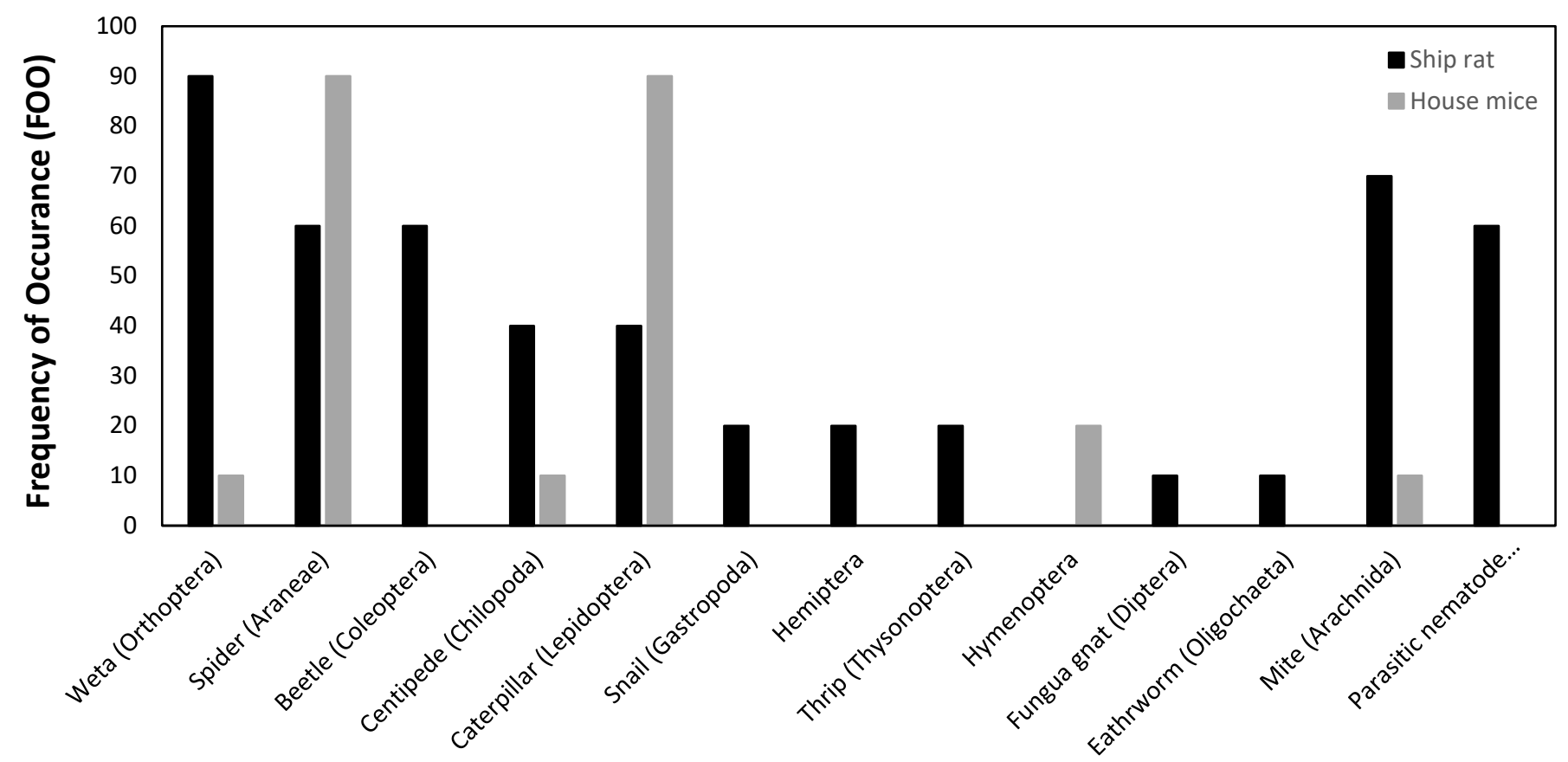





\section{Chapter 5 - General discussion and management recommendations}

\subsection{Summary of new knowledge}

The purpose of this thesis was to fill knowledge gaps around the MGW population in the Mahoenui Giant Wētā Scientific Reserve (MGWSR) in order to provide a holistic picture that could inform future management decisions. In chapter 2, I assessed the current state of the MGWSR finding significant changes in the structure of gorse bushes over the past 14 years. Tall, unbrowsed gorse bushes dominate the reserve in 2018, potentially providing less protection to wētā in the presence of mammalian predators. I additionally assessed the state of the MGW population within the reserve finding a strong declining trend in occupancy estimates and an increase in the average search time required to find wētā. These results suggest MGW are not as abundant and readily found as they were 14 years ago, and that the population is in a state of decline. The covariate 'location' was found to be important in predicting MGW occupancy in 2018, whereby wētā were more likely to occupy monitoring plots in edge habitat. This result could be attributed to a preference for edge habitat by wētā or that plots were just safer resulting in the presence of wētā. Mammal monitoring showed a persistent presence of introduced mammalian pests, rats (Rattus spp.) and house mice (Mus musculus), within the reserve. Brushtail possum (Trichosurus vulpecula) and European hedgehog (Erinaceus europaeus) interference were also commonly recorded. This is not surprising as no regular mammal control is conducted in the reserve except for periodic possum control.

In chapter 3, I assessed the survival rates of MGW in both familiar (gorse) and unfamiliar (native vegetation) habitats. Survival rates, in terms of predation, for adult MGW in the Mahoenui reserve have been unknown until now. Summer radiotracking revealed a high probability of survival in both gorse and native habitats. However, 14 wētā split between three release categories could be considered a small sample size. Low survival rates were observed in the native habitat during autumn, suggesting the lack of protective foliage in conjunction with wētā naivety in an unfamiliar habitat exposed wētā to higher rates of 
predation than when inhabiting gorse. Movement patterns revealed wētā were more active during spring and summer than autumn, and that most wētā moved through gorse and native vegetation in a manner consistent with random-diffusion. MGW movement was also influenced by ambient temperature, whereby wētā moved further in warmer weather. Furthermore, I assessed MGW diurnal refuge use in gorse and native habitats. Wētā in native habitat were most commonly found in the mahoe canopy or around tree fern crowns. Despite previous search efforts, it was not known if MGW were inhabiting the native vegetation, and where they would take refuge if present. The only previous references that provide an insight to MGW diurnal refuge locations in native vegetation are from pest free environments (Watts \& Thornburrow, 2009). Survival estimates suggest it is unlikely MGW are inhabiting the native dominated habitat, however, arboreal monitoring would be required to confirm this. Furthermore, I found that MGW in gorse habitat most commonly took refuge at a height of $0.62-2.38 \mathrm{~m}$ in denser gorse within unbrowsed gorse bushes.

In chapter 4, I attempted to identify potential predators of the MGW in the Mahoenui reserve. Invertebrates are consumed in various quantities by different predators, but are generally an important component in most mammalian predator diets (King, 2005). Nine of the 10 rat stomachs assessed contained wētā remains. Although these could not be visually identified to species level, if rats are predating other wētā such as tree wētā (Hemideina sp.) and cave wētā (Rhaphidophoridae) that also take refuge in the gorse, they are also likely preying on MGW. Rats are known predators of wētā and several studies have identified wètā as important components of rat diets (Innes, 1977; Bridgman 2012 and therein). Wētā remains were found in one mouse stomach, however, spiders and caterpillars were most commonly consumed, which is consistent with numerous other studies assessing house mice diets in New Zealand (Badan, 1986; Fitzgerald et al., 1996; Miller \& Webb, 2001; Watts, 2001; Wilson et al., 2006; Bridgman, 2012). As mice generally target smaller invertebrates (Watts et al., 2017), it is likely they would predate MGW juveniles, nymphs, and eggs rather than adults. Although no wētā remains were found in possum or cat stomachs, both species are known to regularly consume larger-bodied invertebrates such as wētā (Cowan \& Moeed, 1987; Rickard, 1996; Medina \& Garcia, 2007). However, further assessment of all mammalian pest species is needed to obtain a larger sample size for more robust results. 


\subsection{Strategies and recommendations}

\subsubsection{Reducing predation pressure from pest mammals}

It is still unclear exactly what factors are contributing to the decline of MGW. However, controlling introduced mammalian pests populations within the reserve would be recommended as a starting point. MGW survival rates were found to be higher in the gorse habitat than native habitat (Chapter 3), but wētā are still vulnerable to predation in gorse habitat when on or near the ground, or when residing in open 'old man' gorse. Introduced mammalian pests are known to negatively impact native invertebrates (Watt, 1983; Bremner et al., 1984; Moors, 1985; Jones et al., 2005; St Clair, 2011; Watts et al., 2017), and rodents in particular have been implicated in the suppression or extinction of many larger-bodied species (for example weevils (Kuschel \& Worthy, 1996), land snails (Brook, 1999), camel crickets (St Clair et al., 2011), and wētā (Gibbs, 2001; Rufaut \& Gibbs, 2003; Watts et al., 2011)). Mammal control or eradication has generally yielded positive results for invertebrate populations in New Zealand. For example, in the Mackenzie basin where high intensity multispecies mammal control has been conducted over seven years, a significant increase in counts of the threatened rugose grasshopper (Sigaus minutus) was recorded compared to counts in areas with no mammal control (Schori et al., 2019). Similarly, dramatic increases in Auckland tree wētā ( $H$. thoracica) and ground-dwelling beetles (Coleoptera spp.) were recorded following the eradication of mammals from Sanctuary Mountain Maungatautari (Watts et al., 2011, C Watts, unpublished data).

In this study (chapter 4), I was unable to analyse the full array of mammalian predators present within the MGWSR with sufficient sample sizes to make robust conclusions. However, the literature provides evidence that wētā, in general, are an important dietary component of most mammalian predators (see for example Fitzgerald \& Karl, 1979; Rickard, 1996; Wilson et al., 2006; Bridgman, 2012). Rats in particular have been recorded to consume large numbers of wētā (Innes, 1977) and are likely a primary predator of the MGW. Conversely, as discussed in chapter 4 , the control of one mammalian species could lead to knock on effects resulting in predatory or competitive release (Bridgman et al., 2018), prey switching (Smith \& Jamieson, 2003; Medina \& Garcia, 2007), or population irruptions (Witmer et al., 2007). Therefore, I recommend the development of a mammalian pest management plan that targets all mammalian species present within the MGWSR, with a stronger focus on rodents 
than is currently the case. Reducing mice and all mammalian pest species numbers within the reserve will likely benefit the long-term survival of MGW. Furthermore, I recommend further diet analysis of mammalian pest species within the reserve to improve knowledge of MGW predators.

\subsubsection{Long-term management}

A long term option to secure the MGW population would be to construct a predator-excluding fence around the reserve and eradicate mammalian pests inside. Predator-excluding fences have been constructed at numerous locations throughout New Zealand, providing a refuge for native fauna and flora. Zealandia (previously Karori Sanctuary, Wellington) was the first major location to exclude mammalian pests through fencing on the mainland. The fence was constructed in 1999 to conserve vulnerable taxa such as tuatara (Sphenodon punctatus), hihi (Notiomystis cincta), wētā (Hemideina, Hemiandrus, and Gymnoplectron spp.), and Hamilton's frog (Leiopelma hamiltoni; Burns et al., 2012; Innes et al., 2012). Over the past two decades, increases in native seedling densities have been observed in species typically targeted by possums (Innes et al., 2012), in addition to a marked increase in kaka (Nestor meridionalis), red-crowned parakeet (Cyanoramphus novaezelandiae), whitehead (Mohoua albicilla), tomtit (Petroica macrocephala), and bellbird (Anthornis melanura) in the Wellington region (Miskelly et al., 2005). Sanctuary Mountain Maungatautari is another example from the Waikato region. Since 2004, four mammal-excluding enclosures have been built on the mountain (Burns et al., 2012). Double the number of tui (Prosthemadera novaeseelandiae) and bellbird calls have been recorded during five-minute bird counts compared to nontreatment sites (Innes et al., 2012), and adult Auckland tree wētā and ground-dwelling beetle populations were found to have increased 12 -fold and three-fold, respectively, two years following mammal eradication (Watts et al., 2011; C Watts, unpublished data).

The removal of mammals and prevention of re-invasion eliminates the need to encourage and maintain gorse growth within the reserve. Natural succession will eventually result in the natural death of gorse through shading, leaving native vegetation such as Coprosma spp., mahoe, tree ferns, and kanuka behind (Maccarter \& Gaynor, 1980). MGW were thought to have originally inhabited remnant tawa forests (Watts et al., 2013) and are known to browse 
on a variety of native plants (Richards, 1994). Therefore, allowing the reserve to return to its historic pest-free state would not hinder the species survival. Despite some sites containing gorse habitat, the absence of mammalian pests was identified as a key determinant of MGW establishment for translocations between 1989 and 2013 (Watts \& Thornburrow, 2009; Watts, 2013). Other species of wētā, such as tree wētā, ground wētā, and cave wētā, have been found to benefit from the eradication of mammalian predators (Watts et al., 2011). Two years following the mammal eradication at Sanctuary Mountain Maungatautari, dramatic increases in $H$. thoracica (12-fold) and cave and ground wētā (52-fold) populations were recorded (Watts et al., 2011).

Predator excluding fences are expensive and require extensive ground works to install. The fence additionally needs to be regularly monitored and maintained in order to avoid reinvasion of mammalian pests (Burns et al., 2012). However, creating a pest-free sanctuary in Mahoenui would also be beneficial for many other native species. Tui, fantail (Rhipidura fuliginosa), grey warbler (Gerygone igata), sliver eye (Zosterops lateralis), Auckland tree wētā (H. thoracica), ground wētā (Hemiandrus spp.), and skinks (Oligosoma spp.), among others, are present in the area. Zealandia, as discussed above, provides an excellent example of a pest-free mainland island providing refuge for numerous native species leading to the widespread increase of these populations, specifically birds, throughout the Wellington region (Miskelly et al., 2005; Innes et al., 2012).

Gorse gardening could be considered as alternative option, however, it has never been attempted before. The process would involve removing native vegetation, disturbing the ground to encourage gorse seeds banked in the soil to grow (Rees \& Hill, 2001), and maintaining a large feral goat population to browse the shrubs. As gorse is nationally considered a noxious weed that is extremely difficult to control in agricultural and forestry settings (Maccarter \& Gaynor, 1980), preserving it for conservation purposes over native forest is unconventional and may result in opposition from interested parties. Feral goats are also considered a pest (Parkes, 2005), and maintaining large numbers would be equally essential for keeping gorse in a condition that provides protection to MGW (Sherley \& Hayes, 1993). Furthermore, gorse is known to be extremely flammable, especially during the summer when foliage dies off (Richards, 1994). Maintaining gorse habitat over native forest exposes 
the Mahoenui wētā population to an additional threat that could be reduced by allowing natives to take over.

The condition of the gorse should additionally be considered. Gorse spider mites (Tetranychus lintearius) that were introduced to New Zealand in 1989 as a biocontrol (hill et al., 2000), are present within the reserve and appear to have been somewhat successful, altering the quality of the shrubs (Watts, pers. comm., 2018). If gorse is to be maintained into the future, gorse mites may have to be addressed so that gorse quality is sufficient for protecting MGW. Removal of mites can be achieved through the use of insecticide (Manaaki Whenua - Landcare reserach, 2007), but this method is not advised as insecticide may be lethal to MGW as well. Alternative methods, such as biological control by predatory mites (Pratt et al., 2003), would need to be assessed.

Mammal control would need to be ongoing in a gorse dominated reserve, as despite MGW in our study having a higher survival rate in gorse than native habitat (Chapter 3), wētā are still vulnerable to predation when on or near the ground (Richards, 1994). I recorded three predations in gorse habitat during autumn radiotracking (Chapter 3). All MGW remains were found on the ground, however, I cannot rule out the possibility that wētā were preyed upon up in the gorse (Watts \& Thornburrow, 2009). Ship rats and possums are both well known for their climbing abilities (Cowan, 2005; Innes, 2005; Watts \& Thornburrow, 2009).

It is important to note that MGW are only reliant on gorse in the presence of mammalian predators. All three established MGW translocation populations were in pest-free native vegetation dominated sites, and although the stability of these populations are unknown, two decades later wētā are still regularly observed (C Watts, pers. comm., 2018). Site surveys by Watts et al. (2013) recorded MGW tracking rates of $17 \%$ ( $\pm 10 \%)$ on Mahurangi Island Scenic Reserve and $43 \%( \pm 8 \%)$ in Warrenheip (private reserve) 16 and eight years following translocations, respectively. Both locations are dominated by regenerating native vegetation and are relatively mammal-free which appeared to be an important factor influencing the survival of translocated populations (Watts \& Thornburrow, 2009).

For the reasons mentioned above, I believe installing some form of predator excluding fence and mammalian pest eradication in the MGWSR is the best option to implement to ensure the long-term survival of the giant wētā population in Mahoenui. 


\subsubsection{Ongoing monitoring}

A further recommendation is to maintain annual monitoring of the population into the future. Monitoring is important for assessing the necessity for or success of management initiatives (Sweetapple \& Barron, 2016). Without some form of regular monitoring, it is difficult to gauge population dynamics and whether measures taken to safeguard the population from further decline were effective. If gorse is maintained within the reserve, current site-occupancy monitoring methods should be continued with one minor change. The current method provides presence-absence information only, which is not best suited for determining MGW density and population size. Therefore, for one monitoring season (five days), I recommend searching all monitoring plots for 20 minutes and recording all wētā present within a plot. This method will shed light on the relative abundance of wētā across monitoring plots. Additionally, if every wētā found is marked over the five-day search, an estimate of density can be made using mark-recapture analysis (e.g. Lettink \& Armstrong, 2003).

If native vegetation becomes dominant, alternative monitoring methods will need to be applied. From radiotracking MGW in native vegetation during this study, I found wētā tend to take refuge around canopy height during the day and are very difficult to locate in manual searches (Chapter 2). Alternative methods that could be used to monitor MGW in native vegetation include foliage/branch collection (Basset et al., 1997), chemical fogging (Zou et al., 2012), sweep netting (Semere \& Slater, 2007), pit-fall traps (Davis \& Sutton, 1998), artificial refuges (Bleakley et al., 2006), arboreal tracking tunnels (Watts et al., 2008b; Watts et al., 2011), and frass collection (Sweetapple \& Barron, 2016). As MGW are a threatened species, the three former methods would not be advised due to their highly invasive and lethal nature. Pit-fall traps, if non-lethal, could be used either on the ground or up in the canopy. This method is somewhat invasive as wētā are trapped inside containers overnight and it has been found that non-lethal pit-fall traps tend to catch less due to specimens escaping (Seldon \& Beggs, 2010). Artificial refuges are readily used to monitor cavity dwelling tree wētā populations (Bleakley et al., 2006; Watts et al., 2008a) and may provide an index of population size (Bleakley et al., 2006). However, artificial refuges have not been formally tested as a monitoring tool for larger, arboreal giant wētā. Frass collection is a passive method used to monitor the abundance of canopy dwelling invertebrates by simply setting litter trays below vegetation for a period of time (Sweetapple \& Barron, 2016). This method requires the ability 
to distinguish frass between species, which to our knowledge, has not been tested for wētā species.

Tracking tunnels are a novel method for monitoring arboreal invertebrates as they are generally used to monitor rodent presence on the ground (Watts et al., 2008b). The viability of using this method to monitor giant wētā has been tested with $D$. heteracantha (Watts et al., 2008b). Adult giant wētā footprints were found to be distinguishable from other wētā species, suggesting tracking tunnels can be used to monitor adult giant wētā in native vegetation (Watts et al., 2008b). Tunnels in said study were set on the ground over three nights resulting in a $35 \%( \pm 13.4 \%)$ detection rate of adult $D$. heteracantha (Watts et al., 2008b). Ground set tracking tunnels have also been tested with MGW at the MGWSR, Mahurangi Island, and Warrenheip, where Watts et al. (2013) found a positive relationship between the number of wētā found during manual searches and the percentage of footprints on tracking cards. This relationship suggests tracking tunnels could also be used to determine the relative abundance of adult MGW (Watts et al., 2013). Juvenile and sub-adult giant wētā prints were unable to be distinguished from other species using this method (Watts et al., 2008b). Further research into the ideal setting location (ground based or arboreal) when monitoring adult MGW is required.

Providing the new method established for monitoring MGW in native habitat abides by siteoccupancy assumptions (e.g. repeated surveys, independent surveys etc.), site-occupancy modelling can continue to be used to model MGW population trajectory. The change in method will result in new data that is not comparable to the previous data collected in the gorse through manual searches, but will provide a means for monitoring the Mahoenui population. The establishment of regular monitoring for the three persisting translocated populations is additionally recommended.

\subsubsection{Boosting population numbers}

Wild-to-wild translocation is a common tool in conservation management, whereby animals are intentionally relocated in order to expand the numbers and/or ranges of threatened species (Serena \& Williams, 1995). MGW were translocated from the MGWSR to several locations in the North of New Zealand between 1989 and 2013, however, only three of the 
eight populations persist (Watts \& Thornburrow, 2009; Watts, 2012, 2013). Although the stability of these translocated populations has not been assessed, wētā are still detected six to 26 years later (C Watts, pers. comm., 2018). As discussed in chapter 1, the original source population at Mahoenui has shown signs of decline over the past eight years. I recommend that once a pest management plan is well underway and the stability of the translocated populations has been determined as stable or growing, MGW are translocated back to the Mahoenui reserve. This translocation will help increase original population numbers and boost genetic diversity in case any alleles have been lost from the MGWSR population, but retained in the newly founded populations.

Translocation from a captive bred population is an alternative option. Captive breeding is another conservation tool used to boost populations of threatened species (Fountain et al., 2016) and has been utilised for many other endangered species in New Zealand including Kiwi (Apteryx spp.; Sales, 2005), Kakapo (Strigops habroptilus; Elliott et al., 2001), Canterbury knobbled weevil (Hadramphus tuberculatus; Fountain et al., 2016), Campbell Island teal (Anas nesiotis; Gummer \& Williams, 1999), tuatara (Sphenodon spp.; Moore et al., 2008), and Mercury Island tusked wētā (Motuwētā isolata; Stringer \& Chappell, 2008). The captive breeding of MGW has been successfully attempted twice in the past by Richards (1994) and Sherley (1998) as part of general biology research. Captive breeding requires species specific facilities and trained staff which can be costly, but is another tool for increasing the numbers of the original Mahoenui population. 



\section{Literature cited}

Angel, A., Wanless, R. M., \& Cooper, J., (2009). Review of impacts of the introduced house mouse on islands in the Southern Ocean: Are mice equivalent to rats? Biological Invasions, 11(7), 1743-1754.

Atkinson, I. A. E., \& Towns, D. R. (2005). Kiore. In C. M. King (Ed.), The handbook of New Zealand mammals (2nd ed., pp. 159-174). Melbourne, Australia: Oxford University Press.

Badan, D., (1986). Diet of the house mouse (Mus-musculus I) in 2 pine and a kauri forest. New Zealand Journal of Ecology, 9, 137-141.

Balas, C. J. (2008). The effects of conservation programs on amphibians of the Prairie Pothole Region's glaciated plain. (Unpublished Masters Thesis), Humboldt State University, California, USA.

Barker, G. M., (2016). Land snail communities respond to control of invasive rats in New Zealand forests. New Zealand Journal of Ecology, 40(3), 310-320.

Basset, Y., Springate, N. D., Aberlenc, H. P., \& Delvare, G. (1997). A review of methods for sampling arthropods in tree canopies. In N. E. Stork, J. Adis, \& R. K. Didham (Eds.), Canopy arthropods (pp. 27-52).

Bates, D., Maechler, M., Bolker, B., \& Walker, S., (2015). Fitting linear mixed-effects models using Ime4. Journal of Statistical Software, 67(1), 1-48.

Bleakley, C., Stringer, I., Robertson, A., \& Hedderley, D., (2006). Design and use of artificial refuges for monitoring adult tree wētā, Hemideina crassidens and $H$. thoracica. DOC Research \& Development Series, 233, 1-37.

Bonnaud, E., et al., (2011). The diet of feral cats on islands: A review and a call for more studies. Biological Invasions, 13(3), 581-603.

Bowie, M. H., Allen, W. J., McCaw, J., \& van Heugten, R., (2014). Factors influencing occupancy of modified artificial refuges for monitoring the range-restricted Banks Peninsula tree wētā Hemideina ricta (Anostostomatidae). New Zealand Journal of Ecology, 38(1), 132138. 
Braby, M. F., (2017). It's time for action: The need for national action plans for insects and other invertebrates. Austral Entomology, 56(4), 351-354.

Bradburn, M. J., Clark, T. G., Love, S. B., \& Altman, D. G., (2003). Survival analysis part II: Multivariate data analysis - An introduction to concepts and methods. British Journal of Cancer, 89(3), 431-436.

Bremner, A. G., Butcher, C. F., \& Patterson, G. B., (1984). The density of indigenous invertebrates on 3 islands in Breaksea Sound, Fiordland, in relation to the distribution of introduced mammals. Journal of the Royal Society of New Zealand, 14(4), 379-386.

Bridgman, L. J. (2012). Interactions between ship rats and house mice. (Unpublished Doctoral Thesis), University of Waikato, Hamilton, New Zealand.

Bridgman, L., Innes, J., Gillies, C., Fitzgerald, N., Rohan, M., \& King, C., (2018). Interactions between ship rats and house mice at Pureora Forest Park. New Zealand Journal of Zoology, 45(3), 238-256.

Brook, F. J., (1999). Changes in the landsnail fauna of Lady Alice Island, northeastern New Zealand. Journal of the Royal Society of New Zealand, 29(2), 135-157.

Burnham, K. P., \& Anderson, D. R. (2002). Model selection and multimodel inference: A practical information-theoretic approach. (2nd ed.). New York, USA: Springer.

Burns, B., Innes, J., \& Day, T. (2012). The use and potential of pest-proof fencing for ecosystem restoration and fauna conservation in New Zealand. In M. J. Somers \& M. W. Hayward (Eds.), Fencing for conservation: Restriction of evolutionary potential or a riposte to threatening processes? (pp. 65-90). New York, USA: Springer.

Byrom, A. E., Innes, J., \& Binny, R. N., (2016). A review of biodiversity outcomes from possumfocused pest control in New Zealand. Wildlife Research, 43(3), 228-253.

Campbell, P. A., (1973). The feeding behaviour of the hedgehog (Erinaceus europaeus L.) in pasture land in New Zealand. Proceedings of the New Zealand Ecological Society, 20, 3540.

Cardoso, P., Borges, P. A. V., Triantis, K. A., Ferrandez, M. A., \& Martin, J. L., (2011). Adapting the IUCN Red List criteria for invertebrates. Biological Conservation, 144(10), 2432-2440. 
Cardoso, P., Erwin, T. L., Borges, P. A. V., \& New, T. R., (2011). The seven impediments in invertebrate conservation and how to overcome them. Biological Conservation, 144(11), 2647-2655.

Chiari, S., Zauli, A., Mazziotta, A., Luiselli, L., Audisio, P., \& Carpaneto, G. M., (2013). Surveying an endangered saproxylic beetle, Osmoderma eremita, in Mediterranean woodlands: A comparison between different capture methods. Journal of Insect Conservation, 17(1), 171-181.

Chown, S. L., McGeoch, M. A., \& Marshall, D. J., (2002). Diversity and conservation of invertebrates on the sub-Antarctic Prince Edward Islands. African Entomology, 10(1), 6782.

Clapperton, B. K., \& Byrom, A. (2005). Feral ferret. In C. M. King (Ed.), The handbook of New Zealand mammals (2nd ed., pp. 294-308). Melbourne, Australia: Oxford University Press.

Clark, T. G., Bradburn, M. J., Love, S. B., \& Altman, D. G., (2003). Survival analysis part I: Basic concepts and first analyses. British Journal of Cancer, 89(2), 232-238.

Clout, M. N., (2002). Biodiversity loss caused by invasive alien vertebrates. Zeitschrift Fur Jagdwissenschaft, 48, 51-58.

Copson, G. R., (1986). The diet of the introduced rodents Mus-musculus I and Rattus-rattus I on sub-Antarctic Macquarie Island. Australian Wildlife Research, 13(3), 441-445.

Cowan, P. E., \& Moeed, A., (1987). Invertebrates in the diet of brushtail possums, Trichosurusvulpecula, in lowland podocarp broadleaf forest, Orongorongo Valley, Wellington, NewZealand. New Zealand Journal of Zoology, 14(2), 163-177.

Cowan, P. E. (2005). Brushtail possum. In C. M. King (Ed.), The handbook of New Zealand mammals (2nd ed., pp. 56-80). Melbourne, Australia: Oxford University Press.

Daniel, M. J., (1973). Seasonal diet of the ship rat Rattus-rattus-rattus in lowland forest in NewZealand. New Zealand Ecological Society Proceedings, 20, 21-30.

Daugherty, C. H., Gibbs, G. W., \& Hitchmough, R. A., (1993). Mega-island or micro-continent? New Zealand and its fauna. Trends in Ecology \& Evolution, 8(12), 437-442. 
Davis, A. J., \& Sutton, S. L., (1998). The effects of rainforest canopy loss on arboreal dung beetles in Borneo: Implications for the measurement of biodiversity in derived tropical ecosystems. Diversity and Distributions, 4(4), 167-173.

Dent, E. (2016). The impacts of an introduced mammalian predator (Mus musculus) on tree wētā (Hemideina trewicki) and skinks (Oligosoma polychroma, Oligosoma infrapunctatum, and Oligosoma lineoocellatum) in Cape Sanctuary, Hawkes Bay. (Unpublished Masters Thesis), Victoria University of Wellington, Wellington, New Zealand.

Department of Conservation. (2016). Meeting notes; Mahoenui giant wētā species integration. Department of Conservation. Hamilton. Unpublished report.

Department of Conservation. (2016). Follow-up meeting notes from Mahoenui giant wētā species integration exercise. Department of Conservation. Te Kuiti. Unpublished report.

Department of Conservation. (2017). Wildlife act authority application 60994-FAU approval. [Permit]. Te Kuiti, New Zealand. Department of Conservation.

Department of Conservation. (2017). New Zealand's threatened species strategy: Draft for consultation. Wellington, New Zealand: Department of Conservation.

Diekotter, T., Csencsics, D., Rothenbuhler, C., Billeter, R., \& Edwards, P. J., (2005). Movement and dispersal patterns in the bush cricket Pholidoptera griseoaptera: The role of developmental stage and sex. Ecological Entomology, 30(4), 419-427.

Egeter, B., Bishop, P. J., \& Robertson, B. C., (2015). Detecting frogs as prey in the diets of introduced mammals: A comparison between morphological and DNA-based diet analyses. Molecular Ecology Resources, 15(2), 306-316.

Elliott, G. P., Merton, D. V., \& Jansen, P. W., (2001). Intensive management of a critically endangered species: The kakapo. Biological Conservation, 99(1), 121-133.

Field, L. H. (2001). The biology of wētās, king crickets and their allies. Wallingford, UK: CABI Publishing.

Fischer, J. (2016). Ecology, taxonomic status, and conservation of the South Georgian Diving Petrel (Pelecanoides georgicus) in New Zealand. (Unpublished Masters Thesis), Victoria University of Wellington, Wellington, New Zealand. 
Fitzgerald, B. M., \& Karl, B. J., (1979). Foods of feral house cats (Felis-catus I) in forest of the Orongorongo Valley, Wellington. New Zealand Journal of Zoology, 6(1), 107-126.

Fitzgerald, B. M., Daniel, M. J., Fitzgerald, A. E., Karl, B. J., Meads, M. J., \& Notman, P. R., (1996). Factors affecting the numbers of house mice (Mus musculus) in hard beech (Nothofagus truncata) forest. Journal of the Royal Society of New Zealand, 26(2), 237-249.

Fornoff, F., Dechmann, D. K. N., \& Wikelski, M., (2012). Observation of movement and activity via radio-telemetry reveals diurnal behavior of the neotropical katydid Philophyllia ingens (Orthoptera: Tettigoniidae). Ecotropica, 18(1), 27-34.

Fountain, E. D., Pugh, A. R., Wiseman, B. H., Smith, V. R., Cruickshank, R. H., \& Paterson, A. M., (2016). Captive rearing of the endangered weevil Hadramphus tuberculatus (Pascoe, 1877) (Coleoptera: Curculionidae: Molytinae) for ex-situ conservation. New Zealand Entomologist, 39(1), 23-32.

Fukami, T., et al., (2006). Above- and below-ground impacts of introduced predators in seabirddominated island ecosystems. Ecology Letters, 9(12), 1299-1307.

Gibbs, G. W., \& Mclntyre, M. (1997). Abundance and future options for wetapunga on Little Barrier Island (48). Wellington, New Zealand: Department of Conservation.

Gibbs, G. W., (1998). Why are some wētā (Orthoptera: Stenopelmatidae) vulnerable yet others are common? Journal of Insect Conservation, 2(3-4), 161-166.

Gibbs, G. W. (2001). Habitats and biogeography of New Zealand's Deinacridine and tusked wētā species. In L. H. Field (Ed.), Biology of wētās, king crickets, and their allies (pp. 35-55). Wallingford, UK: CABI Publishing.

Gibbs, G. W., (2002). A new species of tusked wētā from the Raukumara Range, North Island, New Zealand (Orthoptera: Anostostomatidae: Motuweta). New Zealand Journal of Zoology, 29(4), 293-301.

Gibbs, G. W., (2009). The end of an 80-million year experiment: A review of evidence describing the impact of introduced rodents on New Zealand's 'mammal-free' invertebrate fauna. Biological Invasions, 11(7), 1587-1593.

Gibbs, G. W., (2010). Do New Zealand invertebrates reflect the dominance of birds in their evolutionary history? New Zealand Journal of Ecology, 34(1), 152-157. 
Gillies, C. A., \& Williams, D. (2013). DOC tracking tunnel guide v2.5.2: Using tracking tunnels to monitor rodents and mustelids. Hamilton, New Zealand: Department of Conservation.

Grant-Hoffman, M. N., \& Barboza, P. S., (2010). Herbivory in invasive rats: Criteria for food selection. Biological Invasions, 12(4), 805-825.

Green, C. J., Gibbs, G. W., \& Barrett, P. A. (2011). Wetapunga (Deinacrida heteracantha) population changes following Pacific rat (Rattus exulans) eradication on Little Barrier Island. In C. R. Veitch, M. N. Clout, \& D. R. Towns (Eds.), Island invasives: Eradication and management. Gland, Switzerland: International Union for Conservation of Nature.

Gummer, H., \& Williams, M., (1999). Campbell Island teal: Conservation update. Wildfowl, 50, 133-138.

Hagen, M., Wikelski, M., \& Kissling, W. D., (2011). Space use of bumblebees (Bombus spp.) revealed by radio-tracking. PLOS One, 6(5), 1-10.

Hansson, L., (1970). Methods of morphological diet micro-analysis in rodents. Oikos, 21(2), 255\&.

Hapca, S., Crawford, J. W., Macmillan, K., Wilson, M. J., \& Young, I. M., (2007). Modelling nematode movement using time-fractional dynamics. Journal of Theoretical Biology, 248(1), 212-224.

Hedin, J., \& Ranius, T., (2002). Using radio telemetry to study dispersal of the beetle Osmoderma eremita, an inhabitant of tree hollows. Computers and Electronics in Agriculture, 35(2-3), 171-180.

Hines, J. E. (2006). PRESENCE-Software to estimate patch occupancy and related parameters. Maryland, United States. USGS-PWRC (Version 2.12.24). http://www.mbrpwrc.usgs.gov/software/presence.html.

Hoffmann, M., et al., (2010). The impact of conservation on the status of the world's vertebrates. Science, 330(6010), 1503-1509.

Horvath, R., Peter, G., Magura, T., \& Tothmeresz, B., (2002). Edge effect on weevils and spiders. Web Ecology, 3, 43-47.

Hothorn, T., Bretz, F., \& Westfall, P., (2008). Simultaneous inference in general parametric models. Biometrical Journal, 50(3), 346-363. 
Inger, R., \& Bearhop, S., (2008). Applications of stable isotope analyses to avian ecology. Ibis, 150(3), 447-461.

Innes, J. G. (1977). Biology and ecology of the ship rat Rattus Rattus Rattus (L.) in Manawatu (NZ) forests. (Unpublished Masters Thesis), Massey university, Palmerston North, New Zealand.

Innes, J., Warburton, B., Williams, D., Speed, H., \& Bradfield, P., (1995). Large-scale poisoning of ship rats (Rattus-rattus) in indigenous forests of the north-island, New-Zealand. New Zealand Journal of Ecology, 19(1), 5-17.

Innes, J. (2005). Ship rat. In C. M. King (Ed.), The handbook of New Zealand mammals (2nd ed., pp. 187-203). Melbourne, Australia: Oxford University Press.

Innes, J. (2005). Norway rat. In C. M. King (Ed.), The handbook of New Zealand mammals (2nd ed., pp. 174-187). Melbourne, Australia: Oxford University Press.

Innes, J., Kelly, D., Overton, J. M., \& Gillies, C., (2010). Predation and other factors currently limiting New Zealand forest birds. New Zealand Journal of Ecology, 34(1), 86-114.

Innes, J., Lee, W. G., Burns, B., Campbell-Hunt, C., Watts, C., Phipps, H., \& Stephens, T., (2012). Role of predator-proof fences in restoring New Zealand's biodiversity: A response to Scofield et al. (2011). New Zealand Journal of Ecology, 36(2), 232-238.

Innes, J., et al. (2014). Impacts of mice alone on biodiversity: Interim report on a Waikato field trial (LC 1990). Hamilton, New Zealand: Manaaki Whenua - Landcare Research.

Jamieson, I. G., Forbes, M. R., \& McKnight, E. B., (2000). Mark-recapture study of mountain stone wētā Hemideina maori (Orthoptera: Anostostomatidae) on rock tor 'islands'. New Zealand Journal of Ecology, 24(2), 209-214.

Jones, C., Moss, K., \& Sanders, M., (2005). Diet of hedgehogs (Erinaceus europaeus) in the upper Waitaki Basin, New Zealand: Implications for conservation. New Zealand Journal of Ecology, 29(1), 29-35.

Jones, C., Norbury, G., \& Bell, T., (2013). Impacts of introduced European hedgehogs on endemic skinks and wētā in tussock grassland. Wildlife Research, 40(1), 36-44. 
Jowett, C. R., \& Plant, A. (1988). Interim management and recovery plan for the Mahoenui giant wētā, Deinacrida sp. (Orthoptera: Stenopelmatidae). Department of Conservation. Te Kuiti. Unpublished report.

Jowett, C. R. (1991). A predation study of the Mahoenui giant wētā. (Unpublished Masters Thesis), University of Auckland, Auckland, New Zealand.

Joyce, S. J., Jamieson, I. G., \& Barker, R., (2004). Survival of adult mountain stone wētā Hemideina maori (Orthoptera: Anostostomatidae) along an altitude gradient as determined by mark-recapture. New Zealand Journal of Ecology, 28(1), 55-61.

Kaplan, E. L., \& Meier, P., (1958). Nonparametric estimation from incomplete observations. Journal of the American Statistical Association, 53(282), 457-481.

Kartzinel, T. R., \& Pringle, R. M., (2015). Molecular detection of invertebrate prey in vertebrate diets: Trophic ecology of Caribbean island lizards. Molecular Ecology Resources, 15(4), 903-914.

Kassambara, A., \& Kosinski, M. (2018). survminer: Drawing survival curves using 'ggplot2'. R package (Version 0.4.3.). Retrieved from: https://cran.r-project.org/package=survminer

Kelly, C D., Bussière, L F., \& Gwynne, D T., (2008). Sexual selection for male mobility in a giant insect with female-biased size dimorphism. The American Naturalist, 172(3), 417-423.

King, C. M. (2005). The handbook of New Zealand mammals. (2nd ed.). Melbourne, Australia: Oxford University Press.

King, C. M. (2005). Weasel. In C. M. King (Ed.), The handbook of New Zealand mammals (2nd ed., pp. 287-294). Melbourne, Australia: Oxford University Press.

King, C. M., \& Murphy, E. C. (2005). Stoat. In C. M. King (Ed.), The handbook of New Zealand mammals (2nd ed., pp. 261-287). Melbourne, Australia: Oxford University Press.

Klare, U., Kamler, J. F., \& Macdonald, D. W., (2011). A comparison and critique of different scatanalysis methods for determining carnivore diet. Mammal Review, 41(4), 294-312.

Kremsater, L., \& Bunnell, F. L. (1999). Edge effects: Theory, evidence and implications to managemant of western North American forests. In J. A. Rochelle, L. A. Lehmann, \& J. Wisniewski (Eds.), Forest fragmentation: Wildlife and management implications (pp. 117-153). Leiden, Netherlands: Brill. 
Kuschel, G., \& Worthy, T. H., (1996). Past distribution of large weevils (Coleoptera:

Curculionidae) in the South Island, New Zealand, based on Holocene fossil remains. New Zealand Entomologist, 19(1), 15-22.

Kuznetsova, A., Brockhoff, P. B., \& Christensen, R. H. B., (2017). ImerTest package: Tests in linear mixed effects models. Journal of Statistical Software, 82(13), 1-26.

Leisnham, P. T., Cameron, C., \& Jamieson, I. G., (2003). Life cycle, survival rates and longevity of an alpine wētā Hemideina maori (Orthoptera: Anostostomatidae) determined using mark-recapture analysis. New Zealand Journal of Ecology, 27(2), 191-200.

Lenth, R. (2018). emmeans: Estimated marginal means, aka least-squares means (Version 1.3.1). Retrieved from: https://CRAN.R-project.org/package=emmeans

Lettink, M., \& Armstrong, D. P., (2003). An introduction to using mark-recapture analysis for monitoring threatened species. Department of Conservation Technical Series, 28, 1-32.

Levett, S., \& Walls, S., (2011). Tracking the elusive life of the Emperor Dragonfly Anax imperator Leach. Journal of the British Dragonfly Society, 27, 59-68.

Liegeois, M., Tixier, P., \& Beaudoin-Ollivier, L., (2016). Use of radio telemetry for studying flight movements of Paysandisia archon (Lepidoptera: Castniidae). Journal of Insect Behavior, 29(2), 199-213.

Lorch, P. D., Sword, G. A., Gwynne, D. T., \& Anderson, G. L., (2005). Radiotelemetry reveals differences in individual movement patterns between outbreak and non-outbreak Mormon cricket populations. Ecological Entomology, 30(5), 548-555.

Maccarter, L. E., \& Gaynor, D. L., (1980). Gorse - A subject for biological-control in New-Zealand. New Zealand Journal of Experimental Agriculture, 8(3-4), 321-330.

MacKenzie, D. I., Nichols, J. D., Lachman, G. B., Droege, S., Royle, J. A., \& Langtimm, C. A., (2002). Estimating site occupancy rates when detection probabilities are less than one. Ecology, 83(8), 2248-2255.

MacKenzie, D. I., Nichols, J. D., Hines, J. E., Knutson, M. G., \& Franklin, A. B., (2003). Estimating site occupancy, colonization, and local extinction when a species is detected imperfectly. Ecology, 84(8), 2200-2207. 
MacKenzie, D. I., \& Bailey, L. L., (2004). Assessing the fit of site-occupancy models. Journal of Agricultural Biological and Environmental Statistics, 9(3), 300-318.

MacKenzie, D. I., \& Nichols, J. D., (2004). Occupancy as a surrogate for abundance estimation. Animal Biodiversity and Conservation, 27(1), 461-467.

MacKenzie, D. I., et al. (2006). Occupancy estimation and modelling: Inferring patterns and dynamics of species occurrence. London, UK: Academic Press.

MacKenzie, D. I. (2012). Review of Mahoenui giant wētā occupancy data. Mosgiel, New Zealand: Proteus wildlife research consultants.

Manaaki Whenua - Landcare Research. (2007). The biological control of weeds book: A New Zealand guide. Lincoln, New Zealand: Manaaki Whenua - Landcare Research.

Marris, J. W. M., (2000). The beetle (Coleoptera) fauna of the Antipodes Islands, with comments on the impact of mice; and an annotated checklist of the insect and arachnid fauna. Journal of the Royal Society of New Zealand, 30(2), 169-195.

McConkey, K. R., Drake, D. R., Meehan, H. J., \& Parsons, N., (2003). Husking stations provide evidence of seed predation by introduced rodents in Tongan rain forests. Biological Conservation, 109(2), 221-225.

McGuinness, C. A. (2001). The conservation requirements of New Zealand's nationally threatened invertebrates (Threatened species occasional publication 20). Wellington, New Zealand: Department of Conservation.

McIntyre, M. (2001). The ecology of some large wētā species in New Zealand. In L. H. Field (Ed.) The biology of wētās, king crickets and their allies. (pp. 225-242). Wallingford, UK: CABI Publishing.

McQueen, S., \& Lawrence, B., (2008). Diet of ship rats following a mast event in beech (Nothofagus spp.) forest. New Zealand Journal of Ecology, 32(2), 214-218.

Medina, F. M., \& Garcia, R., (2007). Predation of insects by feral cats (Felis silvestris catus L., 1758) on an oceanic island (La Palma, Canary Island). Journal of Insect Conservation, 11(2), 203-207. 
Miller, C., \& Miller, T., (1995). Population-dynamics and diet of rodents on Rangitoto Island, New Zealand, including the effect of a 1080 poison operation. New Zealand Journal of Ecology, 19(1), 19-27.

Miller, A. P., \& Webb, P. I., (2001). Diet of house mice (Mus musculus L.) on coastal sand dunes, Otago, New Zealand. New Zealand Journal of Zoology, 28(1), 49-55.

Miskelly, C., Empson, R., \& Wright, K., (2005). Forest birds recolonising Wellington. Notornis, 52(1), 21-26.

Molsher, R., Newsome, A., \& Dickman, C., (1999). Feeding ecology and population dynamics of the feral cat (Felis catus) in relation to the availability of prey in central-eastern New South Wales. Wildlife Research, 26(5), 593-607.

Moore, J. A., Nelson, N. J., Keall, S. N., \& Daugherty, C. H., (2008). Implications of social dominance and multiple paternity for the genetic diversity of a captive-bred reptile population (tuatara). Conservation Genetics, 9(5), 1243-1251.

Moors, P. J., (1985). Norway rats (Rattus norvegicus) on the Noises and Motukawao Islands, Hauraki Gulf, New Zealand. New Zealand Journal of Ecology, 8, 37-54.

Murphy, E. C., Keedwell, R. J., Brown, K. P., \& Westbrooke, I., (2004). Diet of mammalian predators in braided river beds in the central South Island, New Zealand. Wildlife Research, 31(6), 631-638.

Murphy, E., Maddigan, F., Edwards, B., \& Clapperton, K., (2008). Diet of stoats at Okarito Kiwi Sanctuary, south Westland, New Zealand. New Zealand Journal of Ecology, 32(1), 41-45.

Nugent, G., Sweetapple, P. J., Coleman, J., \& Suisted, P. (2000). Possum feeding patterns: Dietary tactics of a reluctant folivore. In T. L. Montague (Ed.), The Brushtail Possum: Biology, impact and management of an introduced marsupial (pp. 10-23). Lincoln, Canterbury, New Zealand: Manaaki Whenua Press.

O'Donnell, C. F. J., \& Hoare, J. M., (2012). Quantifying the benefits of long-term integrated pest control for forest bird populations in a New Zealand temperate rainforest. New Zealand Journal of Ecology, 36(2), 131-140.

Parkes, J. P. (2005). Feral goat. In C. M. King (Ed.), The handbook of New Zealand mammals (2nd ed., pp. 374-392). Melbourne, Australia: Oxford University press. 
Parkes, J. P., Byrom, A. E., \& Edge, K. A., (2017). Eradicating mammals on New Zealand island reserves: What is left to do? New Zealand Journal of Ecology, 41(2), 263-270.

Pratt, P. D., Coombs, E. M., \& Croft, B. A., (2003). Predation by phytoseiid mites on Tetranychus lintearius (Acari: Tetranychidae), an established weed biological control agent of gorse (Ulex europaeus). Biological Control, 26(1), 40-47.

Puntenney, C. P., \& Schorr, R. A., (2016). Patch occupancy and habitat of the hops azure (Celastrina humulus), a rare North American endemic butterfly: Insights for monitoring and conservation. Journal of Insect Conservation, 20(2), 215-222.

Quinnell, A. (2015). Mahoenui giant wētā monitoring report 2015. Department of Conservation. Te Kuiti. Unpublished report.

R Core Team. (2018). R: A language and environment for statistical computing. Vienna, Austria. R Foundation for Statistical Computing (Version 3.5.1). https://www.R-project.org/.

Reardon, J. T., Whitmore, N., Holmes, K. M., Judd, L. M., Hutcheon, A. D., Norbury, G., \& Mackenzie, D. I., (2012). Predator control allows critically endangered lizards to recover on mainland New Zealand. New Zealand Journal of Ecology, 36(2), 141-150.

Rees, M., \& Hill, R. L., (2001). Large-scale disturbances, biological control and the dynamics of gorse populations. Journal of Applied Ecology, 38(2), 364-377.

Reynolds, A. (2013). Beyond optimal searching: Recent developments in the modelling of animal movement patterns as levy walks. In M. A. Lewis, P. K. Maini, \& S. V. Petrovskii (Eds.), Dispersal, individual movement and spatial ecology: A mathematical perspective (pp. 53-76). Berlin, Germany: Springer.

Richards, G. (1994). The ecology and behavior of the Mahoenui giant wētā. (Unpublished Masters Thesis), Massey University, Palmerston North, New Zealand.

Rickard, G. (1996). Introduced small mammals and invertebrate conservation in a lowland podocarp forest, south Westland, New Zealand. (Unpublished Masters Thesis), University of Canterbury, Christchurch, New Zealand.

Rink, M., \& Sinsch, U., (2007). Radio-telemetric monitoring of dispersing stag beetles: Implications for conservation. Journal of Zoology, 272(3), 235-243. 
Rufaut, C. G., \& Gibbs, G. W., (2003). Response of a tree wētā population (Hemideina crassidens) after eradication of the Polynesian rat from a New Zealand Island. Restoration Ecology, 11(1), 13-19.

Ruscoe, W. A., \& Murphy, E. C. (2005). House mouse. In C. M. King (Ed.), The handbook of New Zealand mammals (2nd ed., pp. 204-221). Melbourne, Australia: Oxford University Press.

Ruscoe, W. A., Sweetapple, P. J., Perry, M., \& Duncan, R. P., (2013). Effects of spatially extensive control of invasive rats on abundance of native invertebrates in mainland New Zealand Forests. Conservation Biology, 27(1), 74-82.

Russell, J. C., \& Broome, K. G., (2016). Fifty years of rodent eradications in New Zealand: Another decade of advances. New Zealand Journal of Ecology, 40(2), 197-204.

Ruzickova, J., \& Vesely, M., (2016). Using radio telemetry to track ground beetles: Movement of Carabus ullrichii. Biologia, 71(8), 924-930.

Schori, J. C., Maloney, R. F., Steeves, T. E., \& Murray, T. J., (2019). Evidence that reducing mammalian predators is beneficial for threatened and declining New Zealand grasshoppers. New Zealand Journal of Zoology, 46(2), 149-164.

Sedgeley, J., O'Donnell, C., Lyall, J., Edmonds, H., Simpson, W., Carpenter, J., Hoare, J., \& Mclnnes, K. (2012). DOC best practice manual of conservation techniques for bats. Version 1.0. In T. Greene \& K. McNutt (Eds.), Biodiversity Inventory and Monitoring Toolbox. Wellington, New Zealand: Department of Conservation.

Seldon, D. S., \& Beggs, J. R., (2010). The efficacy of baited and live capture pitfall traps in collecting large-bodied forest carabids. New Zealand Entomologist, 33, 30-37.

Semere, T., \& Slater, F. M., (2007). Invertebrate populations in miscanthus (Miscanthus $x$ giganteus) and reed canary-grass (Phalaris arundinacea) fields. Biomass \& Bioenergy, 31(1), 30-39.

Serena, M., \& Williams, G. A. (1995). Wildlife conservation and reintroduction: An Australasian perspective. In M. Serena (Ed.), Reintroduction Biology of Australian and New Zealand Fauna (pp. 247-252). New South Wales, Australia: Surrey Beatty \& Sons. 
Sherley, G. H., \& Hayes, L. M., (1993). The conservation of a giant wētā (Deinacrida n.sp. Orthoptera: Stenopelmatidae) at Mahoenui, King Country: Habitat use, and other aspects of its ecology. New Zealand Entomologist, 16(0), 55-68.

Sherley, G. H. (1998). Threatened wētā recovery plan (Threatened species recovery plan 25). Wellington, New Zealand: Department of Conservation.

Sherley, G. H., (1998). Translocating a threatened New Zealand giant orthopteran, Deinacrida sp. (Stenopelmatidae): Some lessons. Journal of Insect Conservation, 2(3-4), 195-199.

Shiels, A. B., (2011). Frugivory by introduced black rats (Rattus rattus) promotes dispersal of invasive plant seeds. Biological Invasions, 13(3), 781-792.

Shiels, A. B., Flores, C. A., Khamsing, A., Krushelnycky, P. D., Mosher, S. M., \& Drake, D. R., (2013). Dietary niche differentiation among three species of invasive rodents (Rattus rattus, R-exulans, Mus musculus). Biological Invasions, 15(5), 1037-1048.

Shiels, A. B., Pitt, W. C., Sugihara, R. T., \& Witmer, G. W., (2014). Biology and impacts of Pacific island invasive species. 11. Rattus rattus, the black rat (Rodentia: Muridae). Pacific Science, 68(2), 145-184.

Sinclair, B. J., Lord, J. M., \& Thompson, C. M., (2001). Microhabitat selection and seasonality of alpine invertebrates. Pedobiologia, 45(2), 107-120.

Smith, D., \& Jamieson, I. G., (2003). Movement, diet, and relative abundance of stoats in an alpine habitat. DOC Science Internal Series, 107, 1-16.

Spratt, D. M., (1990). The role of helminths in the biological-control of mammals. International Journal for Parasitology, 20(4), 543-550.

St Clair, J. J. H., (2011). The impacts of invasive rodents on island invertebrates. Biological Conservation, 144(1), 68-81.

St Clair, J. J. H., Poncet, S., Sheehan, D. K., Szekely, T., \& Hilton, G. M., (2011). Responses of an island endemic invertebrate to rodent invasion and eradication. Animal Conservation, 14(1), 66-73.

Strang, K., Castro, I., Blunden, G., \& Shepherd, L., (2018). The diet of weasels (Mustela nivalis vulgaris) from Purerua Peninsula, Bay of Islands, New Zealand. New Zealand Journal of Zoology, 45(1), 83-90. 
Stringer, I. A. N. (2001). The reproductive biology and the eggs of New Zealand Anostostomatidae. In L. H. Field (Ed.), The biology of wētās, king crickets and their allies. (pp. 379-397). Wallingford, UK: CABI Publishing.

Stringer, I. A. N., \& Chappell, R., (2008). Possible rescue from extinction: Transfer of a rare New Zealand tusked wētā to islands in the Mercury group. Journal of Insect Conservation, 12(3-4), 371-382.

Stronge, D. C., Fordham, R. A., \& Minot, E. O., (1997). The foraging ecology of feral goats Capra hircus in the Mahoenui giant wētā reserve, southern King Country, New Zealand. New Zealand Journal of Ecology, 21(1), 81-88.

Sullivan, J. J., Williams, P. A., \& Timmins, S. M., (2007). Secondary forest succession differs through naturalised gorse and native kanuka near Wellington and Nelson. New Zealand Journal of Ecology, 31(1), 22-38.

Sutton, N. L. (2004). Site occupancy modelling of a Mahoenui giant wētā (Deinacrida mahoenui) population. (Unpublished Masters Thesis), University of Waikato, Hamilton, New Zealand.

Sweetapple, P. J., \& Nugent, G., (2007). Ship rat demography and diet following possum control in a mixed podocarp-hardwood forest. New Zealand Journal of Ecology, 31(2), 186-201.

Sweetapple, P., \& Barron, M., (2016). Frass drop for monitoring relative abundance of large arboreal invertebrates in a New Zealand mixed beech forest. New Zealand Journal of Ecology, 40(3), 321-329.

Therneau, T. (2015). A package for survival analysis in S (Version 2.38). Retrieved from: https://CRAN.R-project.org/package=survival

Thomas, J. A., Telfer, M. G., Roy, D. B., Preston, C. D., Greenwood, J. J. D., Asher, J., Fox, R., Clarke, R. T., \& Lawton, J. H., (2004). Comparative losses of British butterflies, birds, and plants and the global extinction crisis. Science, 303(5665), 1879-1881.

Tilles, P. F. C., \& Petrovskii, S. V., (2016). How animals move along? Exactly solvable model of superdiffusive spread resulting from animal's decision making. Journal of Mathematical Biology, 73(1), 227-255. 
Towns, D., Simberloff, D., \& A. E. Atkinson, I., (1997). Restoration of New Zealand islands: Redressing the effects of introduced species. Pacific Conservation Biology, 3, 99.

Trewick, S. A., Johns, P. M., Hitchmough, R. A., Rolfe, J., \& Stringer, I. (2016). Conservation status of New Zealand Orthoptera, 2014 (New Zealand threat classification series 16). Wellington, New Zealand: Department of Conservation.

Viswanathan, G. M., da Luz, M. G. E., Raposo, E. P., \& Stanley, H. E. (2011). The physics of foraging: An introduction to random searches and biological encounters Cambridge, United Kingdom: Cambridge University Press.

Warburton, B., \& Livingstone, P., (2015). Managing and eradicating wildlife tuberculosis in New Zealand. New Zealand Veterinary Journal, 63, 77-88.

Watt, J. C., (1983). Beetles (Coleoptera) of Auckland. Tane, 38(1), 31-50.

Watts, C. (2001). Analysis of invertebrates in mouse stomachs from Rotoiti Nature Recovery Project (LC0102/009). Hamilton, New Zealand: Landcare Research.

Watts, C. H., Thornburrow, D., Green, C. J., \& Agnew, W. R., (2008). Tracking tunnels: A novel method for detecting a threatened New Zealand giant wētā (Orthoptera: Anostostomatidae). New Zealand Journal of Ecology, 32(1), 92-97.

Watts, C. H., Stringer, I., Sherley, G., Gibbs, G., \& Green, C., (2008). History of wētā (Orthoptera: Anostostomatidae) translocation in New Zealand: Lessons learned, islands as sanctuaries and the future. Journal of Insect Conservation, 12(3-4), 359-370.

Watts, C., \& Thornburrow, D., (2009). Where have all the wētā gone? Results after two decades of transferring a threatened New Zealand giant wētā, Deinacrida mahoenui. Journal of Insect Conservation, 13(3), 287-295.

Watts, C., Stringer, I., Thornburrow, D., \& MacKenzie, D., (2011). Are footprint tracking tunnels suitable for monitoring giant wētā (Orthoptera: Anostostomatidae)? Abundance, distribution and movement in relation to tracking rates. Journal of Insect Conservation, 15(3), 433-443.

Watts, C., \& Thornburrow, D., (2011). Habitat use, behaviour, and movement patterns of a threatened New Zealand giant wētā, Deinacrida heteracantha (Anostostomatidae: Orthoptera). Journal of Orthoptera Research, 20(1), 127-135. 
Watts, C. H., Armstrong, D. P., Innes, J., \& Thornburrow, D., (2011). Dramatic increases in wētā (Orthoptera) following mammal eradication on Maungatautari - Evidence from pitfalls and tracking tunnels. New Zealand Journal of Ecology, 35(3), 261-272.

Watts, C. (2012). Transfer report on the translocation of Mahoenui giant wèta from the Mahoenui giant wētā Scientific Reserve to the Southern Exclosure, Maungatautari Scenic Reserve on 13-15 April 2012. Landcare Research. Hamilton. Unpublished report.

Watts, C., Empson, R., Thornburrow, D., \& Rohan, M., (2012). Movements, behaviour, and survival of adult Cook Strait giant wētā (Deinacrida rugosa; Anostostomatidae: Orthoptera) immediately after translocation as revealed by radiotracking. Journal of Insect Conservation, 16(5), 763-776.

Watts, C. (2013). Monitoring report on the translocation of Mahoenui giant wētā from the Mahoenui giant wètā Scientific Reserve to the Southern Exclosure, Maungatautari Scenic Reserve during 28 February and 1 March 2013. Landcare Research. Hamilton. Unpublished report.

Watts, C., Thornburrow, D., Rohan, M., \& Stringer, I., (2013). Effective monitoring of arboreal giant wētā (Deinacrida heteracantha and D. mahoenui; Orthoptera: Anostostomatidae) using footprint tracking tunnels. Journal of Orthoptera Research, 22(2), 93-100.

Watts, C., Thornburrow, D., Cave, V., \& Innes, J., (2014). Beetle community changes following pest mammal control at two biodiversity sanctuaries in Wellington, New Zealand. Journal of the Royal Society of New Zealand, 44(2-3), 61-87.

Watts, C., Innes, J., Wilson, D., Fitzgerald, N., Bartlam, S., Thornburrow, D., Smale, M. C., \& Barker, G. M. (2017). Impacts of mice alone on biodiversity: Final report of a Waikato field trial. (LC2747). Hamilton, New Zealand: Manaaki Whenua - Landcare Research.

Watts, C., Stringer, I., Innes, J., \& Monks, J. M., (2017). Evaluating tree wētā (Orthoptera: Anostostomatidae: Hemideina species) as bioindicators for New Zealand national biodiversity monitoring. Journal of Insect Conservation, 21(4), 583-598.

Watts, C., Thornburrow, D., Stringer, I., \& Cave, V., (2017). Population expansion by Cook Strait giant wētā, Deinacrida rugosa (Orthoptera: Anostostomatidae), following translocation 
to Matiu-Somes Island, New Zealand, and subsequent changes in abundance. Journal of Orthoptera Research, 26(2), 171-180.

Weeks, E. R., \& Swinney, H. L. (1998). Random walks and lévy flights observed in fluid flows. New York, USA: Springer-Verlag.

Wehi, P. M., Jorgensen, M., \& Morgan, D. K. J., (2015). Predictors of relative abundance of tree wētā (Hemideina thoracica) in an urban forest remnant. New Zealand Journal of Ecology, 39(2), 280-285.

Wilmshurst, J. M., Anderson, A. J., Higham, T. F. G., \& Worthy, T. H., (2008). Dating the late prehistoric dispersal of Polynesians to New Zealand using the commensal Pacific rat. Proceedings of the National Academy of Sciences of the United States of America, 105(22), 7676-7680.

Wilson, D. J., McElrea, G. J., McElrea, L. M., Heyward, R. P., Peach, M. E., \& Thomson, C. (2006). Potential conservation impacts of high-altitude small mammals: A field study and literature review (248). Wellington, New Zealand: Department of Conservation.

Witmer, G. W., Boyd, F., \& Hillis-Starr, Z., (2007). The successful eradication of introduced roof rats (Rattus rattus) from Buck Island using diphacinone, followed by an irruption of house mice (Mus musculus). Wildlife Research, 34(2), 108-115.

Wood, E. M. (2007). Occupancy models of focal bird species in central Sierra Nevada foothill woodlands, California. (Unpublished Masters Thesis), Humboldt State University, California, USA.

Worthy, T. H., Tennyson, A. J. D., Archer, M., Musser, A. M., Hand, S. J., Jones, C., Douglas, B. J., McNamara, J. A., \& Beck, R. M. D., (2006). Miocene mammal reveals a Mesozoic ghost lineage on insular New Zealand, southwest Pacific. Proceedings of the National Academy of Sciences of the United States of America, 103(51), 19419-19423.

Wotton, D. M., \& McAlpine, K. G. (2013). Predicting native plant succession through woody weeds in New Zealand (DOC research and development series 336). Wellington, New Zealand: Department of Conservation. 
Zografou, K., Swartz, M. T., Tilden, V. P., McKinney, E. N., Eckenrode, J. A., \& Sewall, B. J., (2017). Severe decline and partial recovery of a rare butterfly on an active military training area. Biological Conservation, 216, 43-50.

Zou, Y., Feng, J., Xue, D., Sang, W., \& Axmacher, J. C., (2012). A comparison of terrestrial arthropod sampling methods. Journal of Resources and Ecology, 3(2), 174-182. 
